\title{
REABILITAÇÃO DE ÁREAS CENTRAIS: ANTAGONISMOS E AMBIGÜIDADES DO PROgRAMA PAUlistano AÇÃo CENTRO
}

\begin{abstract}
Dissertação apresentada à Faculdade de Arquitetura e Urbanismo da Universidade de São Paulo para obtenção do título de Mestre em Arquitetura e Urbanismo
\end{abstract}

Área de concentração: Habitat

Orientador: Prof. Dr. João Sette Whitaker Ferreira

São Paulo, 2008 
Motisuke, Daniela

M918r Reabilitação de áreas centrais: antagonismos e ambigüidades do programa paulistano Ação Centro / Daniela Motisuke. - São Paulo, 2008.

217 p.:il

Dissertação (Mestrado - Área de Concentração: Habitat) FAUUSP. Orientador: João Sette Whitaker Ferreira

1. Áreas Centrais - São Paulo (SP). 2. Política Urbana. 3. Renovação Urbana. 4. Planejamento Estratégico.

CDU 711.523(816.11)

AUTORIZO A REPRODUÇÃO E DIVULGAÇÃO TOTAL OU PARCIAL DESTE TRABALHO, POR QUALQUER MEIO CONVENCIONAL OU ELETRÔNICO, PARA FINS DE ESTUDO E PESQUISA, DESDE QUE CITADA A FONTE.

email:dmotisuke@yahoo.com.br 


\section{AgradeCIMENTOS}

Ao CNPQ pelo apoio à pesquisa durante os meses de outubro de 2005 à maio de 2006.

Ao meu orientador, Professor Dr. João Sette Whitaker Ferreira, pelas importantes contribuições a minha formação.

Às Professoras Dra.Vera Pallamin e Dra. Sarah Feldman pelas proveitosas contribuições, críticas e sugestões, na ocasião da banca de qualificação.

À equipe do Instituto Pólis pelas conversas e trocas de informações referentes à pesquisa "Controle Social de

Políticas Públicas: o Financiamento do BID para a Reabilitação do Centro de São Paulo” - Pólis/CARE.

À equipe do PROCENTRO/EMURB (2005-2008) pelo fornecimento de materiais e informações.

Aos que concederam entrevistas, tornando possíveis muitas das reflexões aqui realizadas.

À equipe do LABHAB, em especial à equipe da pesquisa "Observatório do Solo e da Gestão Fundiária do Centro de São Paulo”, pelos momentos de troca e reflexão conjunta, fundamentais a minha formação.

Às equipes da Subprefeitura de M’Boi Mirim e do Conpresp - Conselho Municipal de Preservação do Patrimônio Histórico, Cultural e Ambiental, pela compreensão de minhas ausências. À Karina Leitão pelas sugestões fundamentais e pela revisão do trabalho.

Às amigas Beatriz Tone e Isadora Tsukumo pelas leituras criteriosas e sugestões fundamentais. À Tatiana Nobre pela tradução e pelas ajudas. À Valéria Bomfim, à Letizia Vitale e à Eneida Heck, pelas conversas e trocas de informações. Aos colegas do DPH - Departamento do Patrimônio Histórico da Secretaria Municipal de Cultura pelas conversas, em especial, Ana Clara Giannecchini, Dalva Thomaz, Denise Invamoto, Sérgio Abrahão e Valdir Arruda.

A todos os amigos que de alguma forma contribuíram com as minhas reflexões, não apenas nesta pesquisa, e que compartilham o desejo de uma cidade justa e democrática.

Ao companheiro Sérgio Franco, pelos almoços e jantares, pela ajuda na transcrição das entrevistas e nas longas conversas e reflexões conjuntas que fizeram desta pesquisa um processo menos solitário.

À família: Paulo, Zezé e Mari Moti, pelo carinho e apoio contínuos. 


\section{SUMÁRIO}

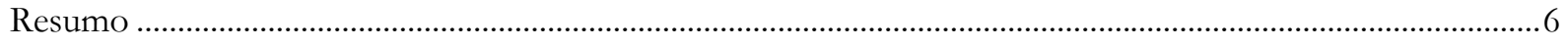

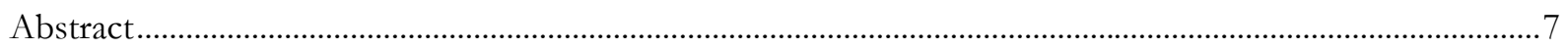

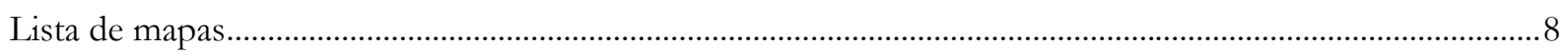

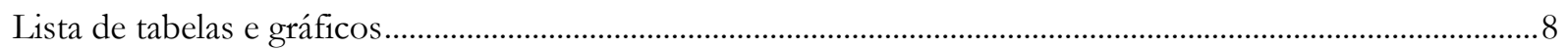

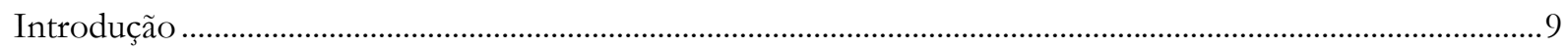

Capítulo 1. Programa de Reabilitação da Área Central de São Paulo - Ação Centro........................................14

1.1. Primeiras Propostas num Contexto de Disputa pelo Centro ………………………………................15

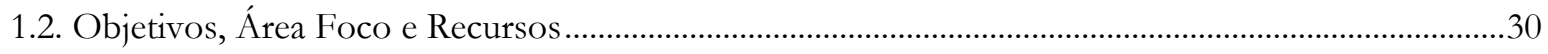

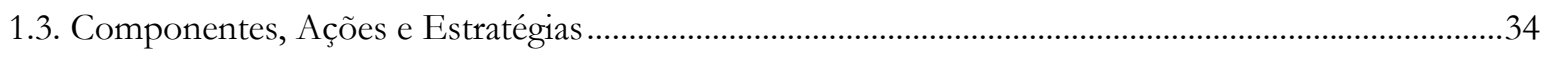

1.3.1. Melhoria do Ambiente Urbano: um mecanismo indutor da transformação.....................................43

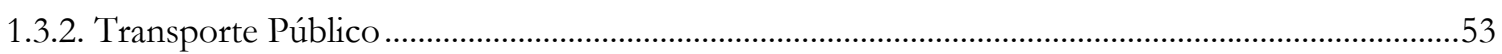

1.3.3. Articulação com a Sociedade Civil e Incentivos à Iniciativa Privada .................................................57

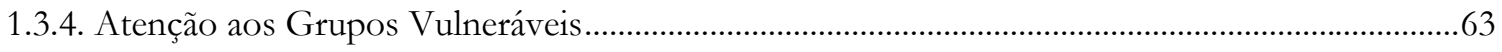

1.3.5. Programas de Habitação Social: manter a população de baixa renda .............................................66

1.4. Operacionalização, Gerenciamento, Monitoramento e Avaliação ..........................................................75

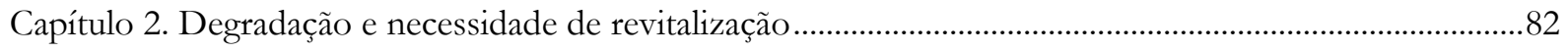

2.1. Primeiros diagnósticos da degradação e iniciativas de revitalização (décadas de 1970 e 1980) ..........83

2.2. Embates entre modelos: diferentes entendimentos de centro (década de 1990) .................................92

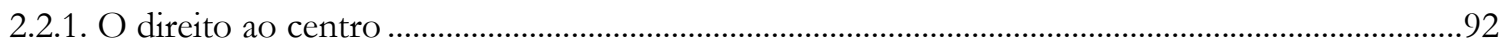

2.2.2. Consolidação das idéias de degradação e revitalização urbana.........................................................99

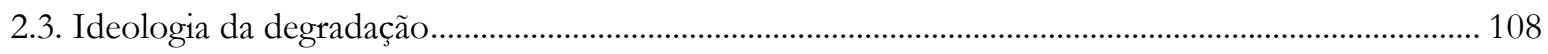

2.4. Delimitando o problema: centro de que? centro de quem? ………………………………………...... 114

Capítulo 3. Modelos urbanísticos e de gestão pública …………………………………………………......... 118

3.1. Experiências estrangeiras ......................................................................................................... 120

3.1.1. Novas práticas urbanísticas: uma breve contextualização.............................................................. 120 
3.1.2. Modelos de intervenção urbana em áreas consideradas degradadas

3.2. Cartilha do BID para a recuperação de áreas centrais

3.2.1. O papel dos organismos multilaterais.

3.2.2. "Best practices": um modelo para o Ação Centro.

3.3. Instrumentos urbanísticos: controle público ou benefício a interesses privados? 167

3.3.1. Origem do conceito de instrumento urbanístico e sua introdução no Brasil. 168

3.3.2. Planos Regionais Sé e Mooca: qual importância para o Ação Centro? 174

3.3.3. Instrumentos urbanísticos do PDE e do PRE e política habitacional. 182

Conclusão. Ambigüidades do Programa Ação Centro. 189

Referências Bibliográficas 201

Anexos. 


\section{RESUMO}

Este trabalho procura identificar os objetivos e estratégias do Programa de Reabilitação da Área Central da cidade de São Paulo, conhecido como Ação Centro, montado durante a gestão da Prefeita Marta Suplicy (2001-2004) no curso das negociações de um financiamento com o Banco Interamericano de Desenvolvimento (BID). Para tanto, analisamos: como se deu a articulação entre seus componentes e ações; diferentes entendimentos das recentes transformações espaciais, econômicas e sociais da área central; os modelos de intervenção e gestão urbana que foram adotados. Mediado por disputas entre distintos interesses, o processo de montagem do programa em estudo foi marcado pela tentativa de amarrar diferentes propostas para a reabilitação da área central, envolvendo estratégias e objetivos antagônicos. Adequando-se ao pensamento dominante da intervenção em áreas centrais, muitas das ações do programa pretendiam uma retomada econômica do centro, com valorização de imóveis e atração de novas empresas, novos usuários e moradores. Nada mais do que o aclamado planejamento estratégico de cidades, e seus métodos de gestão urbana empresarial, amplamente difundido - e imposto - por bancos multilaterais como o BID. A inserção, no escopo do financiamento, de propostas com objetivos contrários (e nem tão alinhados ao pensamento dominante, procurando minimizar os efeitos de expulsão das camadas de baixa renda da área), dotou os discursos produzidos no âmbito do programa de um caráter ambíguo.

Palavras Chaves: Áreas Centrais, Reabilitação Urbana, Programa Ação Centro, Planejamento Estratégico. 


\section{ABSTRACT}

This work aims at identifying the objectives and strategies of the São Paulo city's Central Area Rehabilitation Program, known as Ação Centro, implemented during Mayor Marta Suplicy's municipal administration (2001-2004) in the course of the financial negotiations with the InterAmerican Development Bank (IDB). Therefore, we analyse: the articulation between components and actions; the different understandings of recent spatial, economic and social changes in central area; and the adopted intervention and urban management models. Mediated by disputes between distinct interests, the implementation process of the studied program was marked by the attempt of articulation of different proposals for the central area rehabilitation, involving antagonistic strategies and objectives. Following the main stream theory of central area interventions, most of the actions of the program aimed at an economic reappropriation of the city center, attracting building prices appreciation, and new companies business, users, and dwellers. Nothing more than the acclaimed strategic planning of cities, and its methods of entrepreneurial urban management, widely spread - and imposed - by multilateral banks, like IDB. The insertion, in the financial scope, of proposals with opposite purposes (and not so aligned with the main stream theory objectives, seeking to minimize the effects of low income people eviction), gave the program discourse an ambiguous character.

Key Words: Central Areas, Urban Rehabilitation, Ação Centro Program, Strategic Planning. 


\section{LISTA DE MAPAS}

Mapa 1: Administração Regional da Sé (área de abrangência do Reconstruir o Centro) .................................26

Mapa 2: Área de Interesse e distritos do entorno (Programa Ação Centro) .......................................................32

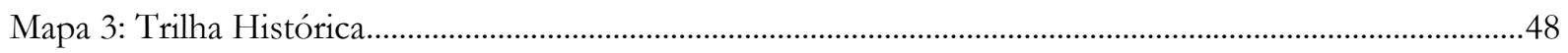

Mapa 4: Propostas do componente "Transporte e Circulação" na Área de Interesse.......................................54

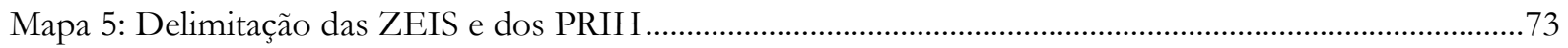

Mapa 6: Instrumentos urbanísticos do PDE e do PRE na área central .......................................................... 179

Mapa 7: Coeficiente de aproveitamento máximo definido no novo zoneamento ........................................ 187

\section{LISTA DE TABELAS E GRÁFICOS}

Tabela 1: Componentes, custos e financiamento do Ação Centro .......................................................................36

Tabela 2: Montantes de recursos por subgrupo de análise .............................................................................41

Gráfico 1: Montantes de recursos por subgrupo de análise ...............................................................................41

Gráfico 2: Montantes de recursos por componente.....................................................................................41

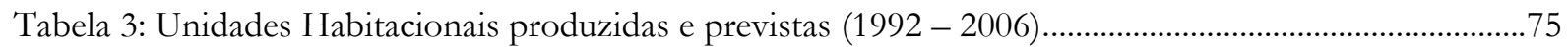

Gráfico 3: Total de Unidades Habitacionais produzidas (1992 - 2006).............................................................75

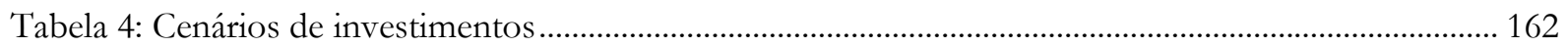




\section{INTRODUÇÃO}

A revitalização ou reabilitação urbana da área central da cidade de São Paulo tem ganhado importância nas agendas dos governos municipal e estadual nas últimas 3 décadas, em especial a partir dos anos 90. Tem sido também defendida por setores da sociedade civil, tornando-se foco de atenções e objeto de projetos específicos. Repovoar, otimizar a infra-estrutura instalada e o estoque construído, preservar o patrimônio histórico, melhorar os espaços públicos e a qualidade de vida são algumas diretrizes recorrentes em projetos e programas lançados no período recente. Tendo como exemplo experiências de países centrais do capitalismo, viu-se a construção de uma idéia dominante do que seria intervir nesta área da cidade, seguindo os atuais modelos e técnicas do chamado planejamento estratégico de cidade para sua "retomada" econômica, social e simbólica.

Embasando os projetos para o centro de São Paulo, indicadores das transformações espaciais, sociais e econômicas da área compõem os diagnósticos que, desde a década de 1970, apontam sua degradação. Esvaziamento, obsolescência, desvalorização, popularização, falta de manutenção, de acessibilidade e de segurança são alguns fenômenos identificados nesses diagnósticos.

Diferentes abordagens da problemática do centro e da área central têm acarretado a elaboração de propostas distintas para sua recuperação, muitas vezes com estratégias e objetivos antagônicos. Há quem entenda os indicadores de outra maneira, ressaltando que as transformações da área permitiram sua apropriação pela maioria da população e - ao contrário da idéia da degradação constituíram um centro deselitizado e acessível a diferentes classes sociais. Com base neste entendimento, surgiram propostas que defendem a permanência dos usos populares e moradores de baixa renda na área, contrapondo-se aos projetos de retomada econômica, que fatalmente 
gerariam sua expulsão. Assim, por meio de diferentes intenções, têm sido travadas disputas pela produção e apropriação do espaço urbano da área central, envolvendo grupos com interesse divergentes.

Esta dissertação de mestrado trata das iniciativas da Prefeitura de São Paulo para a recuperação da área central da cidade, especificamente do Programa de Reabilitação da Área Central, conhecido como Ação Centro, montado durante a gestão da Prefeita Marta Suplicy (2001-2004) no curso das negociações de um financiamento com o Banco Interamericano de Desenvolvimento (BID). As tratativas para esse empréstimo foram iniciadas ainda na gestão Paulo Maluf (1993-1996), continuando ao longo da gestão Celso Pitta (1997-2000). Desde 1996, cartas-consulta foram elaboradas pela Prefeitura a fim de serem analisadas pelo Ministério do Planejamento, pré-selecionadas e enviadas ao banco financiador.

Durante o processo, as propostas para a recuperação da área central da cidade passaram por diversas etapas de montagem, alterações e adaptações, gerando três versões diferentes: o PROCENTRO de 1993 (que embasou a carta-consulta de 1997), o Plano Reconstruir o Centro de 2001 (que embasou a carta-consulta de 2002) e, finalmente, o Programa Ação Centro (aprovado pelo banco em outubro de 2003). Ainda que todas as versões tenham sido formuladas vislumbrando o recurso do BID, em cada uma delas houve mudanças quanto à forma de gestão, à área foco e de abrangência, à organização das ações e intervenções, aos montantes de recursos e à prioridade dada aos vários componentes do programa. Marcaram diferentes entendimentos sobre a intervenção na área central e refletiram demandas de diversos grupos sociais, num contexto de embates entre interesses e projetos díspares que configuravam disputas políticas pela produção e apropriação do espaço urbano do centro.

Em meio a essas disputas, e tentando amarrar diferentes estratégias de intervenção num mesmo projeto, foram inseridos no escopo do Ação Centro programas de assistência social, de geração de emprego e renda e de moradia popular que estavam em implementação pelas respectivas secretarias municipais, alguns deles de caráter inédito na cidade e resultados de discussões conjuntas do poder público com setores da sociedade. A aprovação do Estatuto da Cidade em 2001 contribuiu para as discussões que embasaram muitos desses programas, as quais vinham sendo realizadas desde o início da década de 1990, ainda na gestão Luiza Erundina (1989-1992). Um novo fôlego impulsionou essas discussões, em especial devido à instituição de instrumentos urbanísticos que poderiam conceder ao poder público municipal o efetivo controle sobre a produção do espaço urbano - pelo menos era essa a expectativa - e garantir uma atuação democrática no centro, assegurando o direito à moradia e à cidade. 
Ao mesmo tempo, a Prefeitura manteve e propôs novas ações de estímulo à atração de investimentos privados, à valorização imobiliária e dinamização econômica do centro, atendendo a pressões de outros setores da sociedade, em especial do empresariado e, em grande parte, do próprio BID. Procurava-se reverter o processo de "degradação e desvalorização" da área, através de projetos e intervenções pontuais, de mecanismos de recuperação da valorização imobiliária e articulações com atores da iniciativa privada, estratégias tidas como essenciais para alcançar a efetiva reabilitação e "retomada" do centro. Por sua natureza, estas ações tendem a expulsar os serviços e comércios mais populares e a população moradora de baixa renda, contrapondo-se aos princípios do direito à cidade e à moradia, citados acima.

Desta forma, o objetivo de nossa pesquisa foi identificar os diferentes objetivos e estratégias do Programa Ação Centro, analisando como se deu a articulação de seus componentes e ações, suas mediações com diferentes entendimentos dos recentes fenômenos espaciais, econômicos e sociais da área central e quais os modelos de intervenção e gestão urbana que foram adotados. Procuramos analisar a coesão das propostas da Prefeitura, enquanto política pública para a área central da cidade, o que nos permitiu verificar alguns de seus alinhamentos ideológicos, antagonismos e ambigüidades, mediados pelo contexto de disputas pelo centro.

No primeiro capítulo do trabalho apresentamos o processo de montagem do Programa Ação Centro, destacando alguns dos conflitos, discussões e principais grupos sociais envolvidos, mostrando os diferentes projetos defendidos para a área central da cidade. A partir da sistematização dos documentos oficiais do programa - Planilha de Aquisições, Regulamento Operacional, contrato de empréstimo, informes do banco financiador - e de algumas entrevistas com gestores públicos, estruturamos a análise de suas propostas. Pode-se dizer que o programa justapôs uma séria de propostas heterogêneas, procurando agregar diversas ações que estavam em andamento nos órgãos e secretarias municipais, bem como formular propostas específicas para a recuperação da área central, a partir da coordenação da Empresa Metropolitana de Urbanismo (EMURB).

Os diagnósticos que embasaram - justificaram - a montagem do programa consideraram muitos dos fenômenos apontados anteriormente e se aproximaram daquilo que tem sido caracterizado como degradação da área central, ainda que alguns estudos específicos elaborados no âmbito de determinados componentes tenham apresentado outra leitura da realidade da área.

Discutimos no capítulo 2 a construção da idéia de degradação do centro, desde os anos 70, e como as iniciativas do poder público e de outros grupos da sociedade, em meio às disputas já mencionadas, acabaram se constituindo numa idéia dominante do que significa intervir no 
mesmo - revitalizar através da atração de investimentos privados, gerando uma retomada econômica e a valorização dos imóveis. O capítulo foi finalizado com uma análise sobre o que parece ocorrer nesta área da cidade, em suas mediações com a estrutura metropolitana, e uma breve problematização sobre qual centro se está falando.

No último capítulo, procuramos abordar os principais elementos referenciais, condicionantes e contextuais da estrutura programática do Ação Centro, que determinaram os modelos metodológicos e de gestão urbana adotados. Nele verificamos que experiências de países do primeiro mundo para recuperação de áreas urbanas consideradas degradadas, em especial aquelas que incorporam os discursos de cunho neoliberal da "cidade-global" e que se pautaram nas técnicas do chamado planejamento estratégico, constituíram-se em elementos referenciais para a formulação do programa, ao mesmo tempo em que o próprio BID as apresentava como exemplos "bem sucedidos" que deveriam ser seguidos. Mostramos no capítulo como o banco financiador condicionou o escopo do programa, mesmo diante dos embates entre seus técnicos e os gestores públicos locais, uma vez que a aprovação do empréstimo dependia do atendimento das exigências do contrato. Veremos que os padrões, ajustes e modelos que têm sido difundidos pelos organismos multilaterais, como o BID, permearam toda a montagem do Ação Centro.

Porém, experiências estrangeiras de caráter distinto, correspondendo a outro modelo de desenvolvimento urbano, serviram de referência para parte dos componentes - principalmente do campo da habitação social - ainda que não apontadas pelo banco como exemplos a serem seguidos. Foram experiências de estruturação de políticas habitacionais associadas a iniciativas de reabilitação de bairros históricos centrais, realizadas em países europeus. Também abordamos neste capítulo, o papel atribuído aos novos instrumentos urbanísticos instituídos no Estatuto da Cidade, no Plano Diretor Estratégico de São Paulo e nos Planos Regionais. Buscamos identificar as mediações entre alguns desses instrumentos e o Programa Ação Centro, já que foram apresentados como importantes conjuntos normativos para efetivar parte de seus componentes e a reabilitação da área central proposta.

Ao longo do trabalho, veremos como foram explicitados, através do Programa Ação Centro, os pressupostos de que a área central necessita de investimentos privados para que ocorra sua recuperação - uma retomada econômica com atração de novas empresas, novos usuários e moradores e valorização de imóveis - enquadrando-se na idéia dominante de revitalização, construída ao longo dos anos 90 . O presente trabalho se propõe, portanto, a uma reflexão sobre a função assumida pelos componentes que procuravam garantir a permanência dos usos 
populares e dos moradores e freqüentadores de baixa renda, como as propostas para habitação e assistência social, quando inseridas no escopo do programa e no financiamento do BID.

Faz-se importante destacar ainda que, com a mudança do governo municipal em 2005 (gestão Serra/Kassab, 2005-2008), o programa sofreu consideráveis alterações. Os componentes de habitação, transporte e assistência social foram minimizados, alterados ou excluídos, e as ações foram concentradas no Projeto Nova Luz, que visa renovar a área conhecida como "Cracolândia".

Alinhando-se aos planos de intervenção do governo do Estado para a região (Projeto Pólo Luz) e aos esforços do Programa Monumenta-BID, a atual gestão municipal realizou um conjunto de mudanças relativas à área de abrangência, às estratégias e prioridades do programa de reabilitação da área central. Apesar de corresponder ao mesmo financiamento externo, não faz parte do escopo deste trabalho a análise do novo programa da Prefeitura para o centro, apenas pontuamos alguns aspectos relevantes das mudanças efetuadas, pois nosso enfoque reside na análise do Programa Ação Centro (2002-2004). 


\section{Capítulo 1. Programa de Reabilitação da Área Central de SÃo Paulo - AÇÃo CENTro}

O Programa Ação Centro, formulado a partir de um financiamento com o Banco Interamericano de Desenvolvimento (BID), inseriu-se na linha programática da gestão Marta Suplicy (20012004), que assumiu a Prefeitura de São Paulo colocando a reabilitação como uma de suas prioridades de governo. A expectativa de alguns setores da sociedade, como movimentos populares, grupos de técnicos e acadêmicos engajados na luta por uma cidade justa e democrática, era que se realizasse uma política de recuperação do centro "sem repetir os processos históricos de exclusão que têm acontecido na cidade” (BONDUKI, 2001, p.3).

Neste capítulo, apresentamos um breve histórico do que foi proposto para a área central da cidade no âmbito do empréstimo do BID, as disputas e embates entre projetos defendidos por diferentes setores sociais e como se chegou à estrutura final do Ação Centro, coordenado pela Empresa Metropolitana de Urbanismo (EMURB) ${ }^{1}$. Realizamos uma análise da estrutura de ações do programa, que funcionou como uma espécie de "guarda-chuva", tentando agregar propostas heterogêneas que estavam em andamento nos órgãos e secretarias municipais e/ou que foram formuladas especificamente o programa. Para essa análise, propusemos um agrupamento de ações diferente da organização apresentada nos documentos oficiais, a fim de identificar os objetivos e estratégias existentes - muitos deles conflitantes e antagônicos.

\footnotetext{
1 A EMURB foi criada em 1971 (lei municipal 7.670/1971), "com finalidade específica de executar 'programas de obras de desenvolvimento de áreas urbanas, bem como de renovação das que se apresentarem em processo de deterioração, elaborado, uns e outros, pelos órgãos da própria Prefeitura, e aprovados previamente pela Câmara Municipal” (PMSP/EMURB, 1979d).
} 


\subsection{Primeiras Propostas num Contexto de Disputa pelo Centro}

O início das tratativas com o BID para conseguir um financiamento específico para a recuperação do centro da cidade de São Paulo contou com um documento sucinto enviado a Comissão de Financiamentos Externos do Ministério de Planejamento (COFIEX), ainda no final da gestão Paulo Maluf (1993-1996). Para a montagem desse documento, foram considerados os pressupostos, objetivos e estratégias do PROCENTRO (Programa de Requalificação Urbana e Funcional do Centro de São Paulo) criado em 1993 (lei municipal 33.389/1993)².

Posteriormente, reforçando esse primeiro material, foi enviada uma carta-consulta em maio de 1997 (gestão Celso Pitta, 1997-2000), com o detalhamento das intervenções propostas, organizadas em 4 eixos de ação: (A) Informação e Gestão Urbana; (B) Desenvolvimento Social, Econômico e Ambiental; (C) Infra-estrutura; e (D) Revitalizações Urbanas. Foi apresentado um cronograma físico-financeiro de 4 anos para implementação do programa, prevendo um investimento total de US\$200,74 milhões, sendo 50\% (US\$ 100,32 milhões) de financiamento e $50 \%$ de recursos do Tesouro Municipal (Anexo 1) (PMSP/SEHAB/PROCENTRO, 1997a).

A área foco dessa proposta era o perímetro do PROCENTRO, sua Área Especial de Intervenção (AEI), envolvendo os distritos Sé e República (Centro Velho e Centro Novo) e seu entorno nas porções norte e leste (áreas da Estação da Luz e da Estação Júlio Prestes, do Pátio do Pari, zona cerealista e Parque Dom Pedro II). A proposta visava a "requalificação urbana e funcional da área central", com diversidade de atividades econômicas e recuperação do patrimônio construído (PMSP/SEHAB/PROCENTRO, 1997a), procurando atacar 4 problemas tidos como principais: deterioração ambiental e paisagística; dificuldades de acesso, circulação e estacionamento; obsolescência e insuficiência do estoque imobiliário; e deficiência da segurança pessoal e patrimonial.

Revitalizar a área central, de acordo com a proposta de 1997, significava potencializar a dinâmica econômica e imobiliária local, através da atração de investimentos privados e do estímulo à instalação de atividades terciárias "de ponta" ${ }^{3}$, a fim de alcançar uma mudança nos padrões de

\footnotetext{
2 Através do PROCENTRO foram propostos diversos projetos para a requalificação do centro, inclusive o projeto Pórtico Patriarca, sobre o qual falaremos adiante. Envolveu ações de melhoria em espaços públicos, recuperação de fachadas, criação de mecanismos de estimulo aos investimentos da iniciativa privada, entre outros. Também foi criada a Comissão PROCENTRO para acompanhar as ações na área central e viabilizar parcerias com setores da iniciativa privada, constituída por representantes de diversos órgãos do poder público e da sociedade civil, com caráter deliberativo.

3 O texto da Carta-Consulta de 1997 não definiu as atividades terciárias “de ponta". No entanto, pela análise de outros documento das gestões Maluf e Pitta, bem como de publicações da Associação Viva o Centro - entidade que teve grande influência nas ações realizadas por esses governos para o centro -, entendemos que são serviços do chamado "terciário avançado", associados às atividades empresarias contemporâneas, como telecomunicações, informática e tecnologia, consultoria empresarial, marketing, hotelaria, entre outros. Esse tipo de atividade terciária também é definido por autores que abordam as teorias da "cidade-global", como veremos no capítulo 3 .
} 
uso e ocupação do solo, revertendo o processo de degradação em curso. Seria necessário, portanto, colocar a área central no circuito do mercado imobiliário e atrair a instalação de empresas, comércios e serviços, reforçando seu papel de centro metropolitano em escala internacional, conforme modelos de recentes experiências internacionais - os "grandes projetos de revitalização" em Paris, Londres, Barcelona, Boston, Nova Iorque, entre outros (PMSP/SEHAB/PROCENTRO, 1997a, p.16).

Nesse sentido, as estratégias do PROCENTRO baseavam-se em intervenções urbanísticas de requalificação de espaços públicos e da paisagem urbana, das condições de acessibilidade por automóveis, de implantação de equipamentos culturais e educacionais e de aumento da segurança pessoal e patrimonial, como forma de provocar o envolvimento da iniciativa privada, dando-lhe uma base segura para investir (PMSP/SEHAB/PROCENTRO 1997a:6). Ao mesmo tempo, pretendia rever a legislação urbanística e edilícia existente - a Operação Urbana Centro, recém regulamentada, também integrou esta Carta-Consulta - e buscar "soluções empresarias" para efetivar a participação da iniciativa privada na recuperação da área central, ou seja, concretizar parcerias para a execução de projetos.

Vale notar que, segundo os próprios documentos enviados à COFIEX no período, esses pressupostos e estratégias se ajustavam aos propósitos do BID para a recuperação de áreas urbanas centrais consideradas degradadas.

(...) o PROCENTRO vem desenvolvendo e coordenando ações essencialmente intersetoriais mediante projetos que, embora sejam localizados em termos físico-territoriais, possam induzir interferências positivas em seu entorno, motivando investimentos privados na área central de São Paulo. Estando definida qual a vocação econômica do Centro, para que se direcione projetos, recursos legais, investimentos e a atuação do setor privado de forma objetiva, o Programa poderá agora concretizar as suas diretrizes.

(...) Suas finalidades, campo de atuação e estratégias em curso poderão estar convergentes aos propósitos do BID, cabendo negociações técnicas e financeiras que aprimorem e inovem a melhor forma de cooperação internacional ao PROCENTRO.

Nesse sentido, (...) as negociações, se bem sucedidas, poderão melhor focalizar o caráter indutor antes mencionado dos projetos e a busca do envolvimento da iniciativa privada. (PMSP/SEHAB/PROCENTRO, 1996,2)

Também nessa linha, destaca-se o objetivo de criar uma sustentabilidade econômica das ações de recuperação do centro, tanto pelo aumento da arrecadação pública - impostos e taxas - como por intervenções de recuperação e melhoria de edifícios, feitas pela iniciativa privada. Ou seja, o objetivo era que as melhorias do ambiente urbano, realizadas com recursos públicos, atraíssem a instalação de moradores e usuários de maior renda, com capacidade financeira de manter seus imóveis e o padrão geral da área central. Seguindo os moldes do chamado planejamento 
estratégico $^{4}$, isso seria possível na medida em que as intervenções públicas tornassem o centro mais atrativo para a canalização de investimentos privados, desencadeando transformações nos padrões de uso e ocupação do solo, com dinamização econômica e valorização imobiliária, e alcançando a tão almejada requalificação do centro.

O envolvimento de associações e setores do mercado imobiliário no processo de montagem do programa também contribuiu para (ou mesmo determinou) a importância dada aos pressupostos do planejamento estratégico como meio para a recuperação da área central. Esses grupos traziam referências e modelos de experiências internacionais consideradas "bem sucedidas", pautadas na atração do capital privado e na revalorização de áreas urbanas degradadas. Durante a década de 1990, foram divulgadas experiências da recuperação de centros nos países centrais do capitalismo, na linha da renovação ou revitalização urbana - Baltimore, Nova Iorque e Boston nos Estados Unidos, Londres, Paris e Barcelona na Europa.

A Associação Viva o Centro (AVC), uma entidade representativa de empresários, comerciantes e moradores-proprietários da área central do Município de São Paulo, criada em 1991, teve grande influência no processo de criação e concepção do PROCENTRO de 1993. Encabeçada pelo Banco de Boston, a AVC defendia a reversão da degradação do centro e do processo de êxodo de atividades econômicas para as chamadas "novas centralidades" a sudoeste da cidade, pleiteando iniciativas do poder público no sentido de revitalizar a área central. Além do PROCENTRO, a atuação da AVC também determinou a regulamentação da Operação Urbana Centro (Lei Municipal 12.349/97) e da Lei de Fachadas (Lei Municipal 12.350/97), mecanismos que visavam atrair investimentos privados e possibilitar compensações aos proprietários de imóveis tombados pelos órgãos do patrimônio histórico.

O ProCentro foi uma exigência da Viva o Centro. Eles pediram que o prefeito criasse o ProCentro ou uma agência, ou um organismo no poder público com quem a sociedade civil organizada pela Viva o Centro pudesse interagir, quer dizer, o parceiro público. (...) Nós não fazemos as leis, não temos poder de polícia, não somos poder público. Então a gente precisava realmente da parceria da prefeitura [...] Basicamente mudar as leis, mudar o zoneamento no Centro, que está na raiz de todo o declínio do centro [...] O Centro só tinha restrições. Então a primeira coisa que nós tínhamos de pedir para o poder público era para fazer uma revisão dessas restrições, o que acabou gerando a Operação Urbana Centro... $\left(\right.$ BARRETO, 1997) ${ }^{5}$

\footnotetext{
4 A idéia de planejamento estratégico, como trabalhada no capítulo 3, enfoca a realização de intervenções públicas pontuais, capazes de gerar uma reação em cadeia de dinamização econômica e valorização imobiliária num entorno decadente e obsoleto. Segundo seus defensores, essas intervenções realizadas com recursos públicos, entendidas como "projetos-âncora", seriam necessárias para alavancar o interesse de setores da iniciativa privada em investir nas áreas degradadas, instalando novas empresas e realizando empreendimentos imobiliários.

${ }_{5}^{5}$ Citado em Frugoli Jr (2000, p.81), entrevista cedida ao autor. Em 1997, Jule Barreto era Editor da Revista URBS e do Informe Viva o Centro.
} 
Diante da falta de iniciativas dos governos Paulo Maluf (1993-1996) e Celso Pitta (1997-2000) frente às questões da área central, a Associação teve papel fundamental na difusão da idéia da revitalização do centro, tanto na mídia, como através de seminários e debates; papel esse que, de certo modo, mantém-se até hoje. Fortalecendo a mobilização de moradores e comerciantes da região, coordenou a criação das chamadas "Ações Locais", instâncias de gestão organizadas por rua que buscam a melhoria urbana e uma maior eficiência na zeladoria, através da reivindicação de ações e investimentos da prefeitura e de parcerias com atores locais ${ }^{6}$. A cada eleição municipal, a AVC divulga uma lista de ações que considera necessária para a recuperação da área central, entregando a mesma aos candidatos, a fim de reforçar sua pressão e influência sobre os governos. Pode-se perceber essa intenção no trecho a seguir, de autoria do Superintendente Geral da Associação.

São Paulo mobiliza-se para escolher quem conduzirá a cidade nos próximos quatro anos.
E, pela quarta vez em sua história, a VIVA O CENTRO dirige-se aos candidatos à
Prefeitura para expor suas propostas de medidas prioritárias para a área central. (...) Ao
evidenciar a importância do Centro para o futuro da Metrópole, e ao obter o compromisso
dos candidatos com um programa mínimo de projetos e ações, a VIVA O CENTRO tem
conseguido manter o processo de recuperação do Centro como um projeto cívico e
apartidário, permeando, já, quatro gestões municipais. Após a criação da Associação, em
outubro de 1991, o processo de requalificação do Centro começou efetivamente a
deslanchar, no âmbito do poder público municipal, no final da administração Erundina,
com a conclusão da obra do Vale do Anhangabaú; na gestão Maluf, prosseguiu com a
criação do ProCentro pela Prefeitura; no governo Pitta, a Associação VIVA O CENTRO
conseguiu a aprovação da Lei da Operação Urbana Centro e da Lei das Fachadas, além da
recuperação dos viadutos do Chá e Santa Ifigênia, e, no bojo da renegociação da dívida do
município, uma provisão para um empréstimo de US\$ 100 milhões do BID para o Centro.
Finalmente, na gestão Marta, o Centro foi definitivamente colocado como uma das
prioridades da Prefeitura. (ALMEIDA, 2004) Um dos primeiros eventos organizados pela AVC foi o "Seminário Internacional Centro XXI" em outubro de 1995 e que contou com um encontro preparatório ainda em dezembro de 1994 . Tal seminário não destacou uma questão específica do centro, mas abarcou diversos aspectos de suas transformações recentes, em especial sua degradação, a ocupação por usos e grupos populares, as dificuldades de acessibilidade, obsolescência, esvaziamento residencial e perda de atividades econômicas para as "novas centralidades", a falta de conservação do patrimônio construído e dos espaços públicos, bem como as ações possíveis para sua recuperação, redinamização e revalorização.

O evento, especialmente seu encontro preparatório, contou com a participação de variados grupos, setores e profissionais, além de consultores internacionais, configurando certa diversidade

\footnotetext{
${ }^{6}$ Muitos dos projetos e intervenções em espaços públicos realizados nos últimos anos no centro tiveram influência direta das Ações Locais, como é possível perceber na leitura dos boletins informativos da AVC (Informe Viva o Centro).

${ }^{7}$ Dois documentos da AVC publicaram artigos referentes a este seminário, o do encontro preparatório (VIVA O CENTRO, 1994a) e o do seminário propriamente (VIVA O CENTRO, 2001b).
} 
de pensamentos e posicionamentos ${ }^{8}$ e vislumbrando um espaço possível para o debate e a construção coletiva de uma proposta democrática para a recuperação do centro - nos ares da democratização do final da década anterior. Chegou-se a tratar do direito à cidade e à moradia, abordando as questões da população de rua, da prostituição feminina, das manifestações culturais/artísticas, dos cortiços, da precariedade habitacional e de um plano urbano específico para o centro. No entanto, ao tornar-se explícito um "pensamento único" na AVC, de caráter neoliberal e excludente, também pautado por renomados especialistas internacionais, muitos dos grupos participantes passaram a se contrapor e criticar tal pensamento, como veremos logo adiante.

A partir da difusão desse "pensamento único" da revitalização, a presença no centro do comércio informal de camelôs, de catadores de materiais recicláveis e de moradores de rua passou a ser considerada um entrave pela AVC. Um outro evento realizado pela AVC em maio de 1994, o workshop “O Comércio Informal de Rua e a Requalificação do Centro de São Paulo”, tratou da questão dos camelôs como um dos maiores obstáculos à revitalização da área. O evento resultou na publicação do documento "Camelôs", no qual percebe-se o entendimento da AVC sobre os problemas relacionados à atividade: ilegalidade, cartelização, associação com o contrabando, delinqüência e a sonegação de impostos, significando uma "apropriação privada do espaço público e fator de corrosão urbana" (AVC, 1994b, p.13).

Mesmo se referindo à intrínseca relação desse comércio informal com o contexto de recessão econômica e desemprego da metrópole paulistana, o documento enfatizou que os ambulantes desvalorizam a "estética urbana", gerando um "astral negativo" e uma "feiúra generalizada", que fazem com que as pessoas deixem de freqüentar as regiões com maior concentração de camelôs, como o centro da cidade (AVC, 1994b, p.11-2). Desta forma, o documento conclui que a atividade não deve ser regulamentada, mas sim, suprimida das ruas e ordenada em locais específicos e fechados como os "pop-shoppings".

Invadindo o espaço público para fins de comércio, sonegando impostos, burlando as leis trabalhistas, envolvendo-se em contrabando e outros delitos, corrompendo a administração pública e agredindo o ambiente urbano, o comércio informal de rua é um dos maiores obstáculos à requalificação do Centro de São Paulo. (AVC, 1994b, p.5)

\footnotetext{
${ }^{8}$ Entre os participantes do seminário e do encontro preparatório destacam-se os jornalistas Jule Barreto, Jorge da Cunha Lima da AVC e Gilberto Dimenstein; os pesquisadores da USP Regina Prosperi Meyer (consultora da AVC), Carlos Lemos, Hugo Segawa, Flávio Villaça, Maria Lucia Refinetti, Erminia Maricato e Sarah Feldman; as urbanistas Raquel Rolnik e Nadia Somekh; o presidente do SECOVI Luiz Antônio Pompéia; o presidente do PROCENTRO Sanderley Fiúza; o arquiteto José Eduardo de Assis Lefèvre da EMURB; os arquitetos Helena Saia, Samuel Kruchin, Paulo Mendes da Rocha; o então prefeito de Curitiba Jaime Lerner; e os especialistas estrangeiros Jordi Borja, Manuel de Solà-Morales, François Ascher, Nuno Portas e David Gosling. Vale destacar ainda a participação do então Presidente da República, Fernando Henrique Cardoso, cuja fala de abertura enalteceu o potencial da cidade de São Paulo para entrar na "rede de cidades-globais".
} 
Ora, é preciso enfatizar que a cidade, e em especial seu Centro metropolitano, o espaço mais democrático da urbe, é de todos (classes, estratos, categorias, indivíduos) para uso e fruição, não predação e posse. O caso do camelô se destaca dos demais por sua natureza contraditória. Afinal, ele é o homem do povo que, aliado a forças econômicas nada populares ou democráticas, contribui para a desqualificação do ambiente urbano desse mesmo povo. O camelô é "aliado da burguesia", se a questão é essa e esse o vocabulário. (AVC, 1994b, p.14)

Para atender, em primeiro lugar, ao interesse público, em sua acepção mais ampla, o comércio informal de rua deve obrigatoriamente sair da rua, da praça, da calçada. Isso vale principalmente para o Centro, local de grande concentração de pedestres onde o camelô incomoda e põe em risco a segurança das pessoas mais do que em outras partes da cidade. (AVC, 1994b, p.15)

Nesse contexto, a AVC foi essencial para a consolidação de uma idéia dominante da revitalização de áreas centrais, pautada em princípios neoliberais de gestão urbana e "governança", idéia essa defendida e utilizada pela Prefeitura a partir da incorporação do discurso da AVC. Tal discurso teve como ponto de partida modelos europeus e norte-americanos de diminuição das atribuições do Estado de Bem-Estar Social, em especial sobre a produção do espaço urbano ${ }^{10}$, enfocando a necessidade do poder público de articular ações em parceria com setores da iniciativa privada, uma vez que a atração de investimentos era tida como único mecanismo viável para a revitalização do centro.

Por outro lado, movimentos sociais e grupos de técnicos e acadêmicos engajados na luta por uma cidade justa e democrática passaram a contrapor os pressupostos e objetivos da idéia de revitalizar o centro, batendo de frente com os posicionamentos da Associação Viva o Centro. Críticas às experiências européias e norte-americanas de recuperação de áreas urbanas consideradas degradadas também foram difundidas nessa época, embasando o posicionamento dos grupos contrários à revitalização do centro. O conhecimento dos resultados dessas experiências, que ocasionaram a valorização fundiária e imobiliária das áreas renovadas e, consequentemente, sua "gentrificação", gerou a defesa por mecanismos que garantissem a permanência de populações de baixa renda e por políticas de habitação social no centro.

\footnotetext{
${ }^{9}$ A idéia de "governança", ou empreendedorismo urbano (na expressão de Harvey, 2005b), pode ser entendida como uma gestão urbana compartilhada, diretamente associada à construção de uma "autonomia relativa" dos poderes locais diante do propalado enfraquecimento do Estado (de Bem-Estar Social). Contribuindo para a consolidação dos ideários neoliberais, tal idéia foi difundida nos países centrais do capitalismo, propagandeada como prática "bem sucedida" de tomada de decisões em conjunto com atores e instituições privadas locais, uma vez que se estaria "livre" da "pesada máquina estatal" (FERREIRA, 2001). Especificamente para o caso da recuperação de áreas urbanas centrais, essa idéia tem sido utilizada como base para a realização de parcerias do poder público com a iniciativa privada, em que ações e investimentos do primeiro muitas vezes acabam por beneficiar interesses do segundo.

${ }^{10}$ Cabe lembrar que, no caso brasileiro, a constituição de um Estado de Bem-Estar Social que garantisse os direitos fundamentais, bem como o controle estatal sobre a produção do espaço urbano, nunca ocorreu e, portanto, seu desmanche pode ser considerado um simulacro (OLIVEIRA, 2003).

11 Segundo Bidou-Zachariasen (2006), o termo "gentrification" (do inglês) foi usado pela primeira vez na década de 1960 por Ruth Glass (1963) para designar os processos de recuperação de antigos bairros centrais londrinos, ocupados por habitações precárias e considerados deteriorados, em que ocorria uma "volta" de famílias de renda média e dos investimentos privados, gerando,
} 
Por causa da disputa pelo espaço - e de intenções de limpeza social explícitas ou camufladas - não se conhece nenhuma política de revitalização do centro que não tenha sido acompanhada de valorização e da conseqüente expulsão das famílias mais pobres, mesmo quando existe essa preocupação por parte do poder público. (SILVA, 2000, p.2)

Ao mesmo tempo, a interrupção dos programas de habitação iniciados na gestão Luiza Erundina (1989-1992) e a ausência de uma política habitacional efetiva no centro motivaram ocupações de edifícios vazios na área central, organizadas pelos movimentos de moradia do centro ${ }^{12}$, como forma de pressão sobre os poderes públicos. Um prédio da Secretaria da Fazenda localizado na Rua do Carmo foi o primeiro a ser ocupado, em 1997, seguido pelo edifício do INSS (Instituto Nacional do Seguro Social) a Avenida 9 de Julho e por um conjunto de sobrados da USP (Universidade de São Paulo), na Santa Cecília. Essas ocupações, que passaram a receber o apoio das universidades, de estudantes e professores ${ }^{13}$, representaram também um contraponto às idéias dominantes da recuperação da área central, abordadas acima.

No entanto, as reivindicações dos movimentos de moradia, em conjunto com assessorias técnicas $^{14}$, foram insuficientes para efetivar seus objetivos junto à Prefeitura, de montar uma política habitacional no centro voltada aos moradores de cortiços. Suas propostas tiveram eco apenas em 1998, com a criação do PAC BID da CDHU (Programa de Atuação em Cortiços da Companhia de Desenvolvimento Habitacional e Urbano do Estado de São Paulo), o qual não foi fruto apenas das pressões dos movimentos sociais. Ao contrário, esse programa estava diretamente vinculado às propostas de revitalização do centro (TSUKUMO, 2007) coordenadas pelo Governo do Estado, para valorização imobiliária e erradicação dos cortiços, através de grandes “intervenções urbano-culturais"15, em especial na região do bairro da Luz.

portanto, valorização imobiliária. Esses processos resultaram na expulsão da população de baixa renda (operária) e das atividades econômicas populares, e sua substituição por camadas de maior poder aquisitivo e usos mais sofisticados - era a "nova gentry urbana, isto é, as famílias de classe média" (SMITH, 2006), ocupando antigos bairros degradados.

$12 \mathrm{O}$ surgimento dos movimentos de moradia do centro ocorreu a partir da mobilização de moradores de cortiços na década de 1980, com enfoque no direito à moradia e na reivindicação por melhores condições de vida, sem relação direta com as discussões sobre a revitalização da área central (TSUKUMO, 2007). Formou-se o Movimento de Unificação dos Cortiços, com apoio do Centro Gaspar Garcia de Direitos Humanos, e surgiu a Unificação das Lutas dos Cortiços (ULC) vinculada à Associação dos Trabalhadores da Mooca, que desde a década de 1970 discute a questão. Posteriormente surgiram os demais movimentos, como o Fórum dos Cortiços.

13 No final de 1997 foi realizado o "Laboratório de Projeto Integrado e Participativo para Requalificação de Cortiço", na ocupação da Rua do Ouvidor, contando com a participação de estudantes e professores de várias Faculdades de Arquitetura, como a da USP e da Escola Politécnica de Turim. Destacamos que essa vivência entre integrantes do movimento de moradia do centro e da universidade inspirou, posteriormente, a realização de outros projetos, como o do cortiço da Rua Sólon.

14 As assessorias técnicas são escritórios compostos por profissionais de diversas áreas, entre arquitetos e técnicos sociais, que prestam serviços de projeto, acompanhamento de obras e acompanhamento social para futuros grupos de moradores de habitação de interesse social. Possuem vínculo com os movimentos sociais de moradia, atuando diretamente em suas discussões, como por exemplo, nos processos de mutirão em auto-gestão, e têm atuado nas discussões sobre a Reforma Urbana.

${ }^{15}$ Empresto a terminologia “intervenções urbano-culturais” de Kara-José (2007). Essa vinculação entre a criação de um programa de atuação em cortiços - a fim de eliminá-los - e as intenções de desencadear um processo de revitalização na região da Luz, através da implantação de equipamentos culturais de porte pelo poder público, também estava presente na proposta da prefeitura enviada à COFIEX em 1997. 
No âmbito da Prefeitura, os debates para montagem de um programa de habitação social no centro, com participação dos movimentos sociais, assessorias técnicas e universidades, ganharam corpo apenas no final de 2000, com o resultado das eleições municipais, que deu vitória ao Partido dos Trabalhadores (gestão Marta Suplicy, 2001-2004). O início de um governo municipal considerado progressista animou esse debate e representou uma nova possibilidade para as reivindicações dos diversos grupos sociais.

Alguns seminários também contribuíram com a idéia da habitação social no centro: "Habitação no Centro de São Paulo: como viabilizar essa idéia?”, organizado em 2000 pelo LABHAB FAUUSP (Laboratório de Habitação e Assentamentos Humanos da Faculdade de Arquitetura e Urbanismo da Universidade de São Paulo) e pela Caixa Econômica Federal; "Curso sobre Gestão de Programas de Reabilitação Urbana”, organizado pelo LABHAB FAUUSP, pela École Nationale des Ponts et Chaussées e pelo Pact-Arim Internacional (Mouvement Pact Arim pour l'Amélioration de l'Habitat), também em 2000, além da “Comissão de Estudos sobre Habitação na Área Central", montada em 2001 na Câmara Municipal e coordenada pelo gabinete do vereador Nabil Bonduki. Esses eventos reforçaram a defesa pela constituição de uma política de habitação social no centro e alguns deles, em especial o curso sobre Reabilitação Urbana, trouxeram a referência da política habitacional francesa ${ }^{16}$.

Diante desse contexto, podemos afirmar que a montagem do programa para a recuperação da área central da cidade, ao longo da gestão Marta, ocorria mediante um embate entre diferentes grupos que defendiam projetos opostos para a área, reforçando a disputa política pela produção e apropriação do espaço urbano do centro. Ao longo desse processo, o centro se tornou o foco das atenções de atores sociais díspares, que pressionavam o poder público na implementação de projetos segundo diferentes modelos de desenvolvimento urbano.

Quando assumiu a Prefeitura em 2001, nesse contexto de disputas, o governo Marta Suplicy herdou os encaminhamentos já feitos para a tomada do empréstimo do BID e colocou a recuperação do centro como uma das prioridades da gestão (PMSP/SEHAB, 2004a; PMSP/EMURB;CEBRAP/CEM, 2004e), a qual havia sido um dos compromissos de campanha. Cabe destacar que não houve questionamentos quanto à continuidade das negociações em torno de um financiamento externo, iniciadas nos governos anteriores, cuja prática política era notadamente voltada aos interesses privados, em especial de setores do mercado imobiliário. Além disso, diante do contexto de crise fiscal que se arrastava desde a década de 1980 e dos

${ }_{16}$ Diogo (2004) realizou uma sistematização dos debates, seminários e workshops que traziam referências da experiência francesa para a montagem de uma política habitacional no centro de São Paulo. 
limites ao endividamento dos municípios impostos pela Lei de Responsabilidade Fiscal (Lei Complementar 101/2000), o governo petista viu no financiamento do BID uma das únicas fontes de recursos para intervir no centro ${ }^{17}$. Parece que, em certa medida, este contexto influenciou para que os "padrões" do banco financiador moldassem as iniciativas da Prefeitura frente à reabilitação da área central, como veremos ao longo dessa dissertação.

Num primeiro momento, porém, os projetos da gestão Marta para a área foram pensados a partir da articulação entre as diversas secretarias municipais que atuavam na região, de forma independente do financiamento do BID. Com coordenação da Administração Regional da Sé (ARSÉ), propunha-se um plano de gestão local, visando à instituição de um sistema de planejamento e gestão das diversas ações setoriais, prevendo recursos orçamentários das próprias secretarias (POLIS/CARE, 2007).

Durante a montagem deste primeiro plano, as negociações com o BID foram retomadas, uma vez que o financiamento já havia sido aprovado pelo Governo Federal em 2000, por meio do aval do Senado, no contexto da renegociação da dívida pública, permitindo operações de crédito pelo município de São Paulo ${ }^{18}$. Assim, o financiamento externo foi entendido como uma forma de custear as ações propostas (POLIS/CARE, 2007).

Ao mesmo tempo, com base nas discussões entre as diversas secretarias e incorporando algumas das reivindicações dos movimentos sociais do centro (PMSP/SEHAB/PROCENTRO/ARSÉ, 2001a), a Prefeitura realizou alterações na carta-consulta que tinha sido apresentada à COFIEX em 1997, procurando extrapolar o enfoque em intervenções urbanísticas pontuais que marcou a proposta da gestão municipal anterior. Segundo a arquiteta Sarah Feldman, então consultora da ARSÉ, mesmo havendo embates entre diferentes visões sobre a intervenção na área central, entre a "transposição de modelos internacionais" e as demandas e problemáticas locais, ainda assim, "a questão da habitação popular, entendida como melhoria, produção de HIS $^{19}$ e recuperação de bairros populares foi um consenso" (FELDMAN, apud POLIS/CARE, 2007, p.29).

Rebatizado de Coordenadoria de Programas de Reabilitação da Área Central (Decreto Municipal 40.753/2001), o PROCENTRO passou a ser presidido pela ARSÉ, com novas diretrizes,

\footnotetext{
17 Soma-se a esse contexto, o fato de que o próprio BID procura projetos para financiar, o que Arantes (2004) chama de "escolha recíproca". Ursula Peres, economista que trabalhou como coordenadora de finanças do programa Ação Centro, também aponta essa questão ao afirmar que o "Banco precisa emprestar, faz parte do trabalho dele" (Peres, 2007, apud POLIS/CARE, 2007,p.20). Segundo Arantes, se pelo lado do tomador, o fator determinante para contrair o empréstimo é a "falta de opção", especialmente a falta de opção interna para financiar investimentos, o próprio BID procura projetos para financiar, movimento que Arantes chama de "escolha recíproca".

${ }^{18}$ Houve uma condição de excepecionalidade ao limite de endividamento estipulada pela Lei de Responsabilidade Fiscal, mesmo antes da rolagem da dívida do Município com a União, mediante o pagamento de $13 \%$ da mesma (cerca de 2 bilhões de reais).

${ }^{19}$ Habitação de Interesse Social
} 
composição e ampliação da área de abrangência. Tal Coordenadoria era integrada por um Grupo Executivo - composto por técnicos da SEHAB (Secretaria Municipal de Habitação da Prefeitura de São Paulo) - e pela Comissão PROCENTRO - ampliada em relação à Comissão de $1993^{20}$. Sua missão seria monitorar o novo programa para a área, chamado Plano Reconstruir o Centro, articulando os agentes públicos e privados e gerindo a obtenção de recursos para a reabilitação. Seu perímetro de atuação passou a englobar os 10 distritos que compunham a ARSÉ: República, Sé, Bom Retiro, Pari, Brás, Cambuci, Liberdade, Bela Vista, Consolação e Santa Cecília.

\begin{abstract}
Em conseqüência destas mudanças foram realizados ajustes nas obras e projetos a serem implementados. Estes ajustes se caracterizam, fundamentalmente, pela revisão de prioridades, passando a priorizar obras e intervenções que privilegiam o interesse coletivo e garantem a inclusão social, e pela desconcentração das obras e intervenções, que passam a se distribuir pelos dez distritos incluídos no perímetro do PROCENTRO. Pode-se afirmar que com os mesmos recursos solicitados no projeto original, amplia-se o território e o universo de beneficiários dos investimentos que serão realizados (PMSP/SEHAB/PROCENTRO/ARSÉ, 2001b, p.1).
\end{abstract}

Curioso notar uma mudança na terminologia utilizada para denominar a idéia de recuperar o centro: de "revitalização" e "requalificação" - marcante na proposta de 97 - para "reabilitação". Mesmo que todos esses termos acabem dotando as intervenções na área central de um caráter médico, no sentido de dar "nova vida" ou "nova habilitação" a um corpo doente, essa mudança de terminologia parecia significar, a princípio, uma inversão de prioridades na intervenção da área central em relação à proposta de $1997^{21}$.

O ponto de partida do Plano Reconstruir o Centro foi a dinâmica existente no território da ARSÉ, entendido como "um conjunto único com precisa identidade na cidade": de abrangência metropolitana, com diversidade social e econômica, com a maior oferta de empregos no setor terciário do município, marcado por um importante patrimônio arquitetônico e urbanístico e com um sistema de transportes e circulação que garante condições únicas de acessibilidade. Também caracterizado por alta taxa de subutilização de espaços e infra-estrutura e consideráveis processos de "exclusão social" - moradores de rua, catadores de materiais recicláveis, camelôs.

\footnotetext{
20 A instância de gestão dos programas voltados à recuperação da área central de São Paulo passou por diversas alterações: Comissão do Programa de Requalificação Urbana e Funcional do Centro (de 1998 a 2001); Comissão do Programa de Reabilitação da Área Central (de 2001 a 2003), Comissão Executiva Ação Centro (de 2003 a 2005); e Comissão Executiva Especial Ação Centro (de 2005 até hoje).

${ }^{21}$ Em geral, a bibliografia que discute a recuperação de áreas urbanas degradadas aponta dois conceitos principais: a renovação e a reabilitação (LOPES, 1995; SILVA, 2000). Mesmo com sobreposições, os autores explicam o primeiro como aquele que envolve grande quantidade de demolição, substituição de antigas edificações por novas, mudanças de usos e população, associado aos projetos de reconstrução do pós-guerra; enquanto o segundo significa intervenções atentas ao tecido urbano e social existente, procurando manter os moradores de baixa renda, os usos populares e o patrimônio histórico não monumental ("banal" ou comum), que emergiram em contraponto ao primeiro. A idéia de "revitalização" ou "requalificação", por sua vez, poderia se aproximar do conceito da "reabilitação", na medida em que também se preocupa com a preservação do patrimônio histórico e se pauta na idéia de "intervir na cidade existente". No entanto, ao aceitar maior grau de demolição e substituição do tecido urbano e social existente, se aproxima do conceito da "renovação".
} 
Seus objetivos ressaltavam a preocupação em garantir o interesse coletivo e a "inclusão social" no conjunto de intervenções propostas, ao mesmo tempo em que buscava a ampliação do uso residencial e a diversidade de classes sociais e funções urbanas, através da execução de programas de habitação social. Diante da constatação de grande heterogeneidade de renda, de usos e funções e, até mesmo grupos étnicos, a intenção parecia ser manter tal diversidade existente na área. No entanto, tal intenção, pautando-se numa idéia de "diversidade social", faz emergir alguns questionamentos quanto ao modelo de recuperação da área central que estava sendo proposto, como veremos mais adiante.

A principal estratégia do Reconstruir o Centro era a gestão integrada e participativa do território - o sistema de planejamento e gestão - prevendo a criação da Subprefeitura Centro, o estabelecimento de articulações e parcerias entre os 3 níveis de governo - municipal, estadual e federal - e com diversos setores da sociedade civil - iniciativa privada, ONGs, organizações comunitárias, universidades etc. A Comissão PROCENTRO e a Sub Sé eram entendidas como elementos fundamentais para a realização do programa e a efetivação dessa forma de gestão, o que seria reforçado pela definição de três Áreas Diferenciadas de Gestão, atentando para as especificidades de cada porção urbana ${ }^{22}$.

Entre as mudanças com relação à carta-consulta de 1997, destacava-se a introdução de programas habitacionais, dotando a nova proposta de um caráter democrático e de "inclusão social", a fim de melhorar a qualidade de vida dos habitantes do centro, viabilizar novas moradias, reabilitar edifícios desocupados para o uso habitacional e ampliar políticas de habitação de interesse social (PMSP/SEHAB/PROCENTRO/ARSÉ, 2001b, p.8). Explicitou-se uma alteração na natureza dos projetos de melhoria de espaços públicos, ao quais deixavam de ter como objetivo último a atração de investimentos imobiliários privados e de empresas do setor terciário "de ponta" e passavam a enfocar a melhoria das condições gerais de circulação em suas várias modalidades pedestres, transporte público, veículos particulares, carga e descarga - visando beneficiar o conjunto da população moradora e usuária do centro. A desconcentração das intervenções, através da ampliação do perímetro de atuação do programa, foi também uma alteração relevante do Reconstruir o Centro, pautando-se num pressuposto contrário ao da proposta de 1997.

Desta forma, propunha-se a criação de 8 subprogramas para a reabilitação: Andar no centro; Morar no centro; Trabalhar no centro; Descobrir o centro; Preservar o centro; Investir no centro;

22 Essas 3 áreas de gestão eram: i) Área de Gestão Centro Velho/Centro Novo (distritos Sé e República e parcelas dos distritos Brás, Bom Retiro e Santa Cecília); ii) Área de Gestão Norte/Leste/Sudeste (distritos Brás, Pari, Bom Retiro, Cambuci, e parcela do distrito Liberdade); e iii) Área de Gestão Sudoeste (distritos Consolação, Santa Cecília, Bela Vista e parcela do distrito Liberdade). 
Cuidar do centro; Governar o centro. Esse conjunto de subprogramas envolvia: melhoria do espaço público; recuperação de edifícios com valor histórico e estímulo ao seu uso turístico/educacional; criação de infra-estrutura de suporte aos usuários do centro (estacionamentos, guarda-volumes, banheiros públicos), como forma de melhorar as áreas comerciais e de serviços; ordenamento do comércio ambulante; capacitação profissional e geração de renda para moradores de rua (reciclagem, e produtos necessários para manutenção e limpeza urbana, como vassouras, uniformes, reforma de calçadas etc.); projetos urbanísticos em grandes áreas urbanas; estímulo a investimentos privados; reabilitação de edifícios desocupados para o uso habitacional; produção de habitação de interesse social; intervenções de melhoria em cortiços; e monitoramento dos impactos sociais e econômicos negativos, possivelmente decorrentes das intervenções.

\section{Mapa 1: Administração Regional da SÉ (ÁREA de AbrangÊNCIA do RECONSTRUir o CENTRO)}

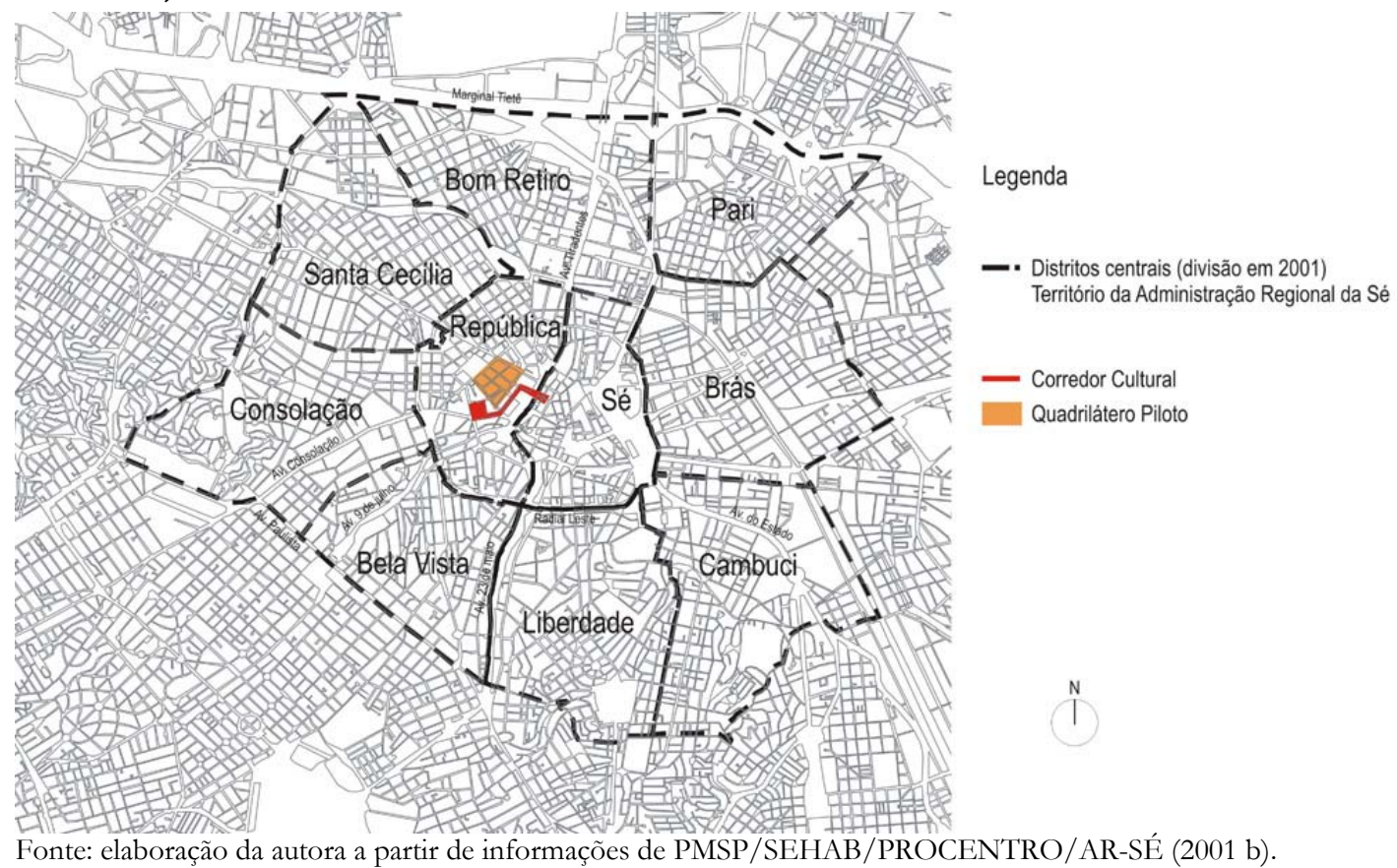

Em seu conjunto de subprogramas, também estavam os projetos Quadrilátero Piloto e Corredor Cultural, com vistas a realizar intervenções urbanísticas de reforma de calçadas, reordenamento de mobiliário e equipamentos urbanos, fachadas e anúncios publicitários e o controle do comércio informal. O primeiro se constituiu por um conjunto de quadras localizadas no Centro Novo (mapa 1) e o segundo por um eixo de ligação entre os Centros Velho e Novo (mapa 1), incluindo projetos especiais de iluminação, sinalização e o projeto Pórtico Patriarca na praça de mesmo nome, cobrindo a entrada da Galeria Prestes Maia. Ambos os projetos, posteriormente 
incorporados pelo Programa Ação Centro, foram realizados com recursos arrecadados pela Operação Urbana Centro.

Apesar de ter um enfoque no planejamento e na gestão integrada das políticas setoriais e recursos dos diversos órgãos municipais, o Reconstruir o Centro não deixou de abarcar intervenções de caráter estratégico. Mantendo os 4 componentes/eixos do programa de 1997, bem como o montante de recursos destinado a cada um deles, propôs a realização de intervenções urbanísticas em grandes áreas consideradas desocupadas ou com usos inadequados e previu a adequação da legislação urbanística, a fim de possibilitar os novos investimentos privados compatíveis com as características e potencialidades da área central - assim como na proposta de 1997 e no programa Ação Centro aprovado pelo BID em 2004. As primeiras foram inseridas no subprograma Investir no Centro, demonstrando a estratégia de realizar melhorias urbanas que gerassem a atração de capital privado; e a segunda, permitindo exceções aos parâmetros construtivos e urbanísticos vigentes, também era vista como forma de viabilizar a realização de empreendimentos de Habitação de Interesse Social pela iniciativa privada.

Destacam-se as seguintes intervenções urbanísticas propostas: Favela do Gato, com projeto de habitação de interesse social e sua adequação com a questão ambiental; Orla Ferroviária e Pátio do Pari, visando sua ocupação por usos diversificados e abertura de espaços públicos; e o Parque Dom Pedro II, que seria recuperado como parque urbano e agregaria intervenções no entorno (Rua 25 de Março, Mercado Municipal e zona cerealista). Quanto à revisão da legislação urbanística, foram montados grupos de trabalho com o objetivo de discutir, avaliar e propor alterações nos instrumentos urbanísticos incidentes no centro, a Operação Urbana Centro e a Lei de Fachadas, regulamentadas durante a gestão Celso Pitta, como mencionado.

Além disso, estavam em andamento as discussões para elaboração do Plano Diretor na cidade, prevendo um novo zoneamento e a montagem de Planos Regionais no âmbito da descentralização administrativa (criação das Subprefeituras). Como veremos no capítulo 3, essas discussões ganharam fôlego diante da aprovação do Estatuto da Cidade em julho de 2001 (Lei Federal 10.257/2001), introduzindo novos instrumentos urbanísticos associados à Luta pela Reforma Urbana, com vistas a garantir o direito à cidade e à moradia. Entre outras questões, esse marco legal contribuiu para a defesa da habitação social no centro, instituindo mecanismos de indução ao cumprimento da função social da propriedade ${ }^{23}$, apesar de não possibilitar sua

$23 \mathrm{O}$ conceito de função social da propriedade, associado à constituição de um Estado Social (ou Estado de Bem-Estar Social), está diretamente ligado às transformações no tratamento legal da propriedade privada - especificamente da propriedade imobiliária urbana. Nesse contexto, parte-se de uma convivência entre direitos distintos em que há um controle do direito individual sobre a propriedade, ou seja, toda propriedade deve cumprir um papel e ter um uso que serve aos interesses coletivos e 
aplicação automática, remetendo-a à esfera dos municípios pela obrigatoriedade de elaboração de Planos Diretores.

Em dezembro de 2001, formou-se o Fórum Centro Vivo (FCV), ainda no bojo da vitória do Partido dos Trabalhadores no governo municipal e, ao mesmo tempo, crítico ao governo que se instituía. Formado por estudantes e entidades de universidades, institutos de pesquisa, ONGs, grupos culturais e representantes de movimentos populares, sua atuação fortaleceu a oposição aos discursos dominantes da revitalização do centro, representados pela AVC.

Uma de suas primeiras atividades foi a realização de debates sobre o Plano Reconstruir o Centro, o que resultou em críticas e sugestões compiladas no documento "Contribuições Preliminares para o Plano Reconstruir o Centro", de 12 de Junho de 2001 (FCV, 2001). Seus principais apontamentos recaíram sobre a ausência de uma política de habitação social, que atendesse as faixas de renda mais baixas (até 3 salários mínimos), ao mesmo tempo em que eram mantidos os instrumentos e mecanismos de atração de investimentos privados, de moradores de renda média e usos mais sofisticados, como a Operação Urbana Centro. Essa continuidade, ao lado da realização de "intervenções de grande porte" como mecanismo de atração de investimentos privados e da ausência de propostas de controle sobre o mercado imobiliário, era vista como entrave para a efetivação de uma política de recuperação da área central com "inclusão" e produção de habitação social. O discurso da "diversidade social e econômica" também foi foco de críticas do Fórum, entendendo-a como forma de naturalizar as desigualdades existentes, reforçando o tratamento diferenciado dado a cada grupo social.

Nesse sentido, o FCV propunha a revogação da Operação Urbana Centro, cobrava a regulamentação dos mecanismos que fizessem cumprir a função social da propriedade e permitissem o controle sobre a especulação imobiliária, e exigia a montagem de programas e linhas de financiamento habitacionais que fossem efetivos no atendimento à demanda existente (abaixo de 6 salários mínimos). Entendia-se que as propostas que buscavam atrair investimentos privados e, consequentemente, gerar valorização imobiliária, eram contrárias e incompatíveis com o objetivo de "inclusão social” do programa.

A O.U. Centro visa atrair um tipo de uso do terciário avançado, e tem como objetivo uma reconversão dos espaços que serve mais aos grandes projetos imobiliários do que à reciclagem dos edifícios para fins sociais. Ao promover a valorização imobiliária, pode-se inviabilizar a inclusão social, objetivo do Plano Reconstruir o Centro, uma vez que o preço dos imóveis atualmente já dificulta a realização de uma política habitacional, e leva muitos inquilinos à condição de encortiçados (FCV, 2001, p.3).

sociais, não podendo ser retida para fins especulativos ou outros que beneficiem apenas os interesses privados e individuais dos proprietários. Tsukumo (2007) problematizou esse conceito a partir de uma bibliografia do campo do direito urbanístico. 
Paralelamente, com base no Plano Reconstruir o Centro, foi encaminhada outra carta-consulta à COFIEX, datada de março de 2002, a partir da qual foi dado prosseguimento às negociações com o BID. No entanto, de acordo com gestores públicos que assumiram a montagem do programa a partir de $2002^{24}$, as propostas que constaram na carta-consulta de 2002 previam ações dispersas e privilegiavam a zeladoria urbana - as necessidades cotidianas da ARSÉ - distantes dos preceitos que deveriam, necessariamente, nortear um projeto estratégico de revitalização urbana; preceitos esses defendidos pelo BID. Dessa forma, o governo municipal não encampou o Plano Reconstruir o Centro e reiniciou o processo de montagem do programa, o que culminou com a aprovação do Ação Centro pelo banco financiador em outubro de 2003 e assinatura do contrato de empréstimo em junho de 2004.

Durante esse processo, o BID realizou diversas "missões" na Prefeitura, visando acompanhar a revisão e averiguar a implementação de algumas das ações que já estavam em andamento. Em cada uma dessas "missões" eram elaborados documentos "Ajuda Memória de Missão", em que constavam os avanços realizados, as discussões travadas e os encaminhamentos tomados. $\mathrm{O}$ banco também indicou os especialistas e consultores que deveriam participar da revisão, reforçando sua influência direta na concepção final, e nas formas de gestão e monitoramento ${ }^{25}$.

Muitas das propostas constantes na carta de 2002 foram inseridas no novo programa, depois de embates entre técnicos da Prefeitura e do BID, passando por revisões e adaptações aos padrões e exigências do financiamento externo. Esse novo processo acarretou alterações na área foco, na organização de suas intervenções e nos montantes de recursos destinados a cada componente, mas manteve a postura de compilar as ações setoriais em andamento nos diversos órgãos e secretarias municipais - o que se tornou uma "marca" do Ação Centro: montagem e ações conjuntas (SOMEKH, 2004a).

O escopo e forma de gestão do programa também tiveram mudanças consideráveis, exacerbando um cunho estratégico-empresarial de intervenção urbana. Sua montagem e gestão, antes concentradas na Administração Regional da Sé, passaram para coordenação da Empresa Metropolitana de Urbanismo (EMURB), em sua Diretoria de Desenvolvimento. Essa transferência, bem como mudanças de prioridades e abandono da dimensão da gestão local

\footnotetext{
${ }^{24}$ Ursula Dias Peres, então Superintendente de Projetos Urbanos da EMURB e coordenadora de finanças do programa Ação Centro, em entrevista cedida à autora em dezembro de 2007; Luis Octávio da Silva, gestor público que integrou a equipe do Ação Centro, em entrevista cedida em janeiro de 2008; Nádia Somekh, então Presidente da EMURB, em entrevista cedida em janeiro de 2008.

25 Arantes (2004) sistematiza o processo de aprovação e formatação dos contratos de empréstimos do Banco Mundial e do BID, apontando que há um procedimento padrão no qual é comum a realização de "missões" e indicação de consultorias - um dossiê de "boas práticas" e assessoria técnica, como suporte ao detalhamento dos projetos a serem financiados.
} 
participativa, reforçou o pressuposto de que a área central necessita de investimentos privados para sua recuperação, ou seja, para alcançar uma retomada econômica da área. A essas alturas, a Associação Viva o Centro, "descontente" com o andamento das propostas para o centro quando essas estavam a cargo da ARSÉ e pressionando por maior interlocução com o governo municipal, voltava à cena participando mais ativamente das discussões. Também na visão de Marco Antônio Ramos de Almeida, superintendente geral da Viva o Centro ${ }^{26}$, havia um conflito entre as demandas do dia a dia da ARSÉ e o pensamento estratégico, necessário a um programa de recuperação do centro.

Ao mesmo tempo, foram inseridos no escopo do Ação Centro os programas habitacionais e sociais em andamento, cuja formulação contou com a importante participação de movimentos populares, grupos de profissionais, estudantes, pesquisadores e do Fórum Centro Vivo - como apontado anteriormente. Nesse contexto, e seguindo os pressupostos e objetivos pautados por tais programas, a proposta para a reabilitação da área central assumiu em seu discurso a necessidade de realizar uma intervenção "com inclusão social”, principalmente como estratégia de minimizar os impactos da valorização imobiliária decorrente da própria reabilitação.

\subsection{Objetivos, Área Foco E RECURSos}

Segundo os materiais de divulgação e o Regulamento Operacional do Programa Ação Centro, seu objetivo seria recuperar a área central da cidade a fim de "reverter o processo de degradação e desvalorização afetiva" (PMSP/EMURB, 2004a). Seu "alvo" era a recuperação de áreas degradadas; a melhoria da qualidade ambiental; o fomento à pluralidade econômica; a "inclusão social"; e a reversão do esvaziamento residencial.

O Programa tem a finalidade de promover o desenvolvimento social e econômico com diversidade da Área Central de São Paulo, dinamizando e criando condições de atração e suporte de atividades compatíveis com o centro metropolitano e promovendo a reabilitação urbanística e ambiental da área, com inclusão social. (PMSP/EMURB, 2004d).

Entendendo que "a região central reserva boas oportunidades para novos empreendimentos de negócios e residenciais" (PMSP/EMURB, 2004a), o programa almejava a instalação de novos usos, moradores de renda média, órgãos do poder público e a canalização de investimentos privados. Ao mesmo tempo, explicitava a intenção de garantir a "inclusão social" ao longo processo de reabilitação da área central, atentando para grupos socialmente vulneráveis -

${ }^{26}$ Em entrevista cedida à autora em dezembro de 2007. 
moradores de rua, catadores de materiais recicláveis, moradores de cortiços - e buscando a "diversidade social".

O principal benefício do Programa é o desenvolvimento econômico e social da área central de São Paulo, mediante a atração, dinamização e manutenção de atividades econômicas compatíveis com o centro reabilitado da cidade, traduzido num incremento do produto interno bruto da cidade de São Paulo e do tamanho do mercado efetivo de trabalho. O benefício social do Programa será sua capacidade para promover e ampliar a inclusão social no centro de São Paulo. O programa irá beneficiar populações tradicionalmente esquecidas ou excluídas dos processos de urbanização em geral. (BID, 2004a, itens 4.27 e 4.28)

Esses foram os objetivos apresentados oficialmente nos documentos do programa, no entanto, ao longo desse capítulo, veremos que existiam intenções contraditórias inseridas num mesmo discurso que defendia uma reabilitação com atração de investimentos privados, em geral, alinhando-se aos princípios da "gestão urbana empresarial", porém com "diversidade" e "inclusão social”. No nosso entender, sob os auspícios da pluralidade sócio-econômica e da reversão do esvaziamento residencial (defesa da diversidade), construiu-se um discurso ideológico da recuperação da área central, mascarando os objetivos de redinamização econômica e valorização imobiliária (ganhos privados, portanto), pelos quais pressionavam setores dominantes do mercado imobiliário.

Os discursos em defesa da diversidade - a riqueza das cidades - surgiram nos movimentos de contracultura do final dos anos 60, na Europa e nos Estados Unidos, que no campo do planejamento e da intervenção urbana procuravam se contrapor modelo moderno considerado homogêneo, funcionalista e autoritário - como veremos no capítulo 3. Mas, posteriormente, tais discursos foram apropriados por outros grupos e passaram a ser utilizados também em políticas de caráter neoliberal - uma troca de mãos de bandeiras. Bidou-Zachariasen (2006) e Smith (2006) já destacaram que a idéia de "diversidade social" tem sido frequentemente utilizada de forma associada aos projetos de revitalização de centros e de bairros centrais mundo afora, escondendo os objetivos de atração de camadas de renda média e de "gentrificação". Segundo os autores, uma vez que esses bairros são considerados deteriorados e marcadamente ocupados por usos e classes populares, as estratégias de revitalização têm se pautado na idéia de que a "volta" de camadas médias geraria uma mudança na "imagem da cidade", necessária ao desencadeamento de investimentos privados que revertam a degradação.

Por exigência do banco financiador, as ações do programa Ação Centro deveriam ser focalizadas na área dos distritos Sé e República, delimitada pela contra-rótula viária (Centro Histórico), a qual foi denominada de Área de Interesse. Descartava-se a proposta do Reconstruir o Centro de englobar os 10 distritos da ARSÉ e constituía-se um perímetro similar àquele da carta-consulta de 1997. Tinha como princípio que a focalização de ações otimizaria os investimentos, 
potencializaria as transformações esperadas e causaria "efeitos de sinergia", permitindo o alcance de resultados mais promissores em relação aos seus objetivos de recuperação da área.

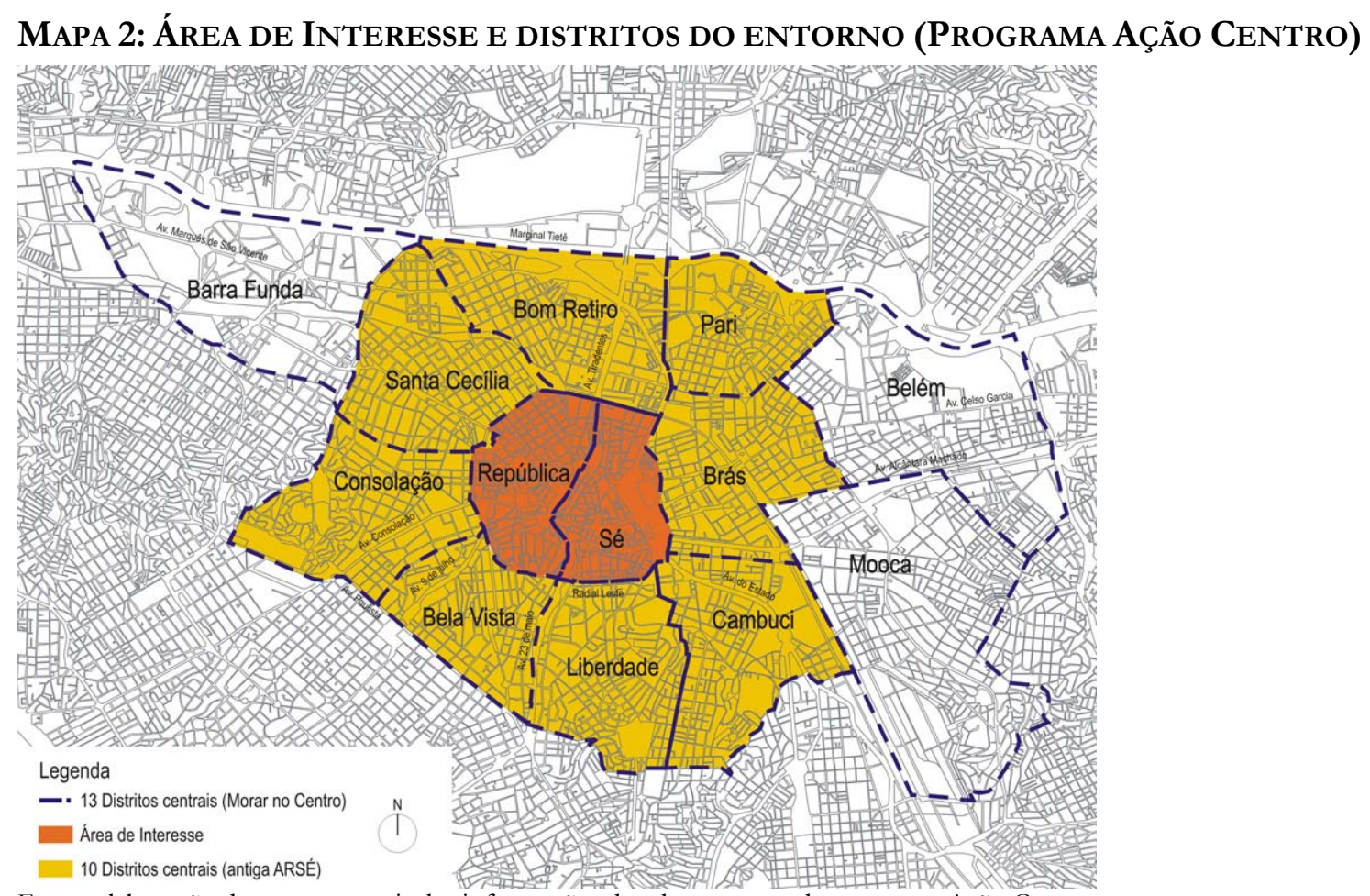

Fonte: elaboração da autora a partir das informações dos documentos do programa Ação Centro.

Voltaremos a essa questão no capítulo 3, mas cabe apontar que tal focalização representou a escolha por uma estratégia de intervenção urbana alinhada à lógica econômico-financeira que tem sido difundida pelos organismos multilaterais, inclusive pelo BID. Segundo Nádia Somekh, coordenadora do programa, foi realizada uma pesquisa com a população que reforçou a opção pela focalização.

(...) nós fizemos uma pesquisa qualitativa com diversas faixas de renda para entender o que era o centro no imaginário da população, e a gente percebeu que o Cambuci, a Liberdade, a Bela Vista não eram Centro, eram bairros centrais, nem a Luz entrava neste imaginário. O centro para população era: a Praça da Sé, o Parque Dom Pedro, o Palácio das Indústrias, a Praça da República e o Viaduto do Chá. (...) ficou fácil definir como perímetro do programa do centro os distritos Sé e República, o que era um pouco a demanda do Viva o Centro, mas não era de todo errado se a gente quisesse focalizar. (SOMEKH, 2008) ${ }^{27}$

Ainda assim, o Ação Centro manteve algumas das ações propostas no Plano Reconstruir o Centro que tinham como área de atuação os distritos que circundam a Área de Interesse (Bom

\footnotetext{
${ }^{27}$ Em entrevista cedida à autora em janeiro de 2008.
} 
Retiro, Cambuci, Liberdade, Bela Vista, Consolação e Santa Cecília, Brás e Pari ${ }^{28}$, o que foi considerado como área de abrangência. Entre as ações mantidas, destacam-se o empreendimento habitacional do Parque do Gato e os Perímetros de Reabilitação Integrada do Habitat (PRIH) (Somekh, 2004a, p.80).

O montante de recursos destinados ao programa totalizou US\$167,4 milhões, sendo US $\$ 100,4$ milhões de financiamento externo e US\$ 67 milhões de contrapartida local. De início, o BID exigia uma contrapartida no mesmo valor do financiamento, porém foi possível diminuir essa proporção no andar das negociações. Segundo Somekh (2004a) e Silva (2004), essa diminuição se deu pela inserção no programa de muitos componentes sociais: habitação, assistência, geração de emprego e renda, etc. O contrato de financiamento, como já mencionado, foi assinado em junho de 2004 e ainda está vigente.

Os procedimentos para desembolso de recursos e aprovação de contrapartidas realizadas envolviam uma série de documentações e condições estipuladas no contrato. Entre essas últimas, a criação de uma instância de gestão compartilhada - a Agência de Desenvolvimento do Centro e de um sistema de avaliação e monitoramento das ações do programa. Para gerir os recursos a prefeitura deveria utilizar um fundo rotativo equivalente a até $5 \%$ do montante do empréstimo, do qual sacaria quantias que futuramente seriam consideradas como desembolso ou contrapartida. Os desembolsados deveriam ser realizados num prazo mínimo de 3 anos e máximo de 6 anos a partir da vigência do contrato, sendo que o comprometimento de recursos assinatura dos contratos de serviços, aquisições, etc. - deveria ocorrer em até 5 anos após a vigência do contrato.

Segundo o contrato de empréstimo, a forma de pagamento do financiamento envolve juros baseado em taxa variável ${ }^{29}$, calculado sobre o saldo devedor diário, devendo ser pago semestralmente a partir de 2 de dezembro de 2004. Ou seja, a Prefeitura já está pagando pelo dinheiro emprestado. Quanto à amortização, começará a ser paga em dezembro de 2010, com parcelas semestrais e iguais, e terminará em junho de 2029.

Entre o final de 2003 e o primeiro semestre de 2004, período entre a aprovação do financiamento pelo Senado e o fechamento do contrato, a prefeitura atendeu as condições exigidas para o primeiro desembolso do empréstimo, sendo que após a assinatura do contrato, houve a primeira liberação de recursos no valor de US\$ 5 milhões. Segundo o documento "Comentários sobre a

\footnotetext{
${ }_{28}$ No caso dos programas habitacionais, e de alguns programas assistenciais, a área de abrangência envolveu também os distritos Mooca, Belém e Barra Funda.

29 Segundo as Normas Gerais, a taxa de juros se baseia em cesta de moedas, com iniciais de 6\%, variando aproximadamente 0,5\% ao mês (taxa LIBOR).
} 
Execução do Programa Ação Centro. Estágio de Avanço” (GUERRA, 2004), até o final de 2004 os investimentos totalizavam US\$24,6 milhões, distribuídos por diversas ações e descriminados em US\$ 11,3 milhões de desembolsos do financiamento e US\$13,3 milhões de contrapartida local aprovada. Nesse momento, também foram comprometidos cerca de US\$ 8 milhões que, somados aos investimentos já realizados, representaram cerca de $20 \%$ do total previsto para o programa. Entre as ações realizadas com esses recursos destacaram-se as intervenções no Mercado Municipal, utilizando recursos da contrapartida local, e as ações do subprograma Morar no Centro que incluíram a construção dos empreendimentos Parque do Gato e Olarias, utilizando recursos do banco.

\subsection{COMPONENTES, AÇõES E EsTratégIAS}

Diferentemente das propostas de 1997 e 2001, o escopo do Programa Ação Centro foi organizado em 5 componentes ou eixos, divididos em diversos subprogramas e intervenções, totalizando cerca de 130 ações (PMSP/EMURB, 2004a), além do item de supervisão e administração, envolvendo um sistema de monitoramento e avaliação da implantação das ações, seu gerenciamento e a realização de uma auditoria externa à Prefeitura. Conforme descritos na tabela 1, os 5 componentes eram: (i) Reversão da Desvalorização Imobiliária e Recuperação da Função Residencial; (ii) Transformação do Perfil Econômico e Social; (iii) Recuperação do Ambiente Urbano; (iv) Transporte e Circulação; e (v) Fortalecimento Institucional do Município.

Esse escopo resultou da somatória de diversas ações em andamento nas secretarias municipais e daquelas elaboradas especificamente para a recuperação da área central, em geral, propostas pela EMURB, envolvendo intervenções bastante heterogêneas. Segundo os gestores do programa ${ }^{30}$, foram realizadas diversas reuniões com representantes das secretarias para definir quais ações entrariam no programa, o que foi amplamente permeado pela necessidade de adequação aos formatos do BID - descritivo das ações, serviços, obras e equipamentos envolvidos; projeto executivo com orçamentos; formas de licitação de acordo com padrões do banco; entre outros.

Ao longo de sua montagem e implementação, o conjunto de ações sofreu diversas alterações, mesmo após a assinatura do contrato de empréstimo. Isso ocorreu devido, principalmente, às dificuldades em comprovar perante o banco as documentações para reembolso dos gastos com ações realizadas como contrapartida local ou para desembolso dos recursos do financiamento.

\footnotetext{
30 Ursula Dias Peres (2007); Luis Octávio da Silva (2008); Renata Milanesi, gestora pública integrante da equipe do Programa Ação Centro, em entrevista cedida à autora em janeiro de 2008.
} 
Em alguns casos, chegou-se a prever que determinada ação contaria com recursos do financiamento e, posteriormente, em função das dificuldades na comprovação dos gastos de acordo com os padrões do BID, passou a ser considerada como contrapartida. Havia, portanto, certa flexibilidade na listagem de ações, desde que mantidos os 5 componentes/eixos principais. O montante de cada ação também poderia variar, já que seu detalhamento ou elaboração de projeto executivo poderia acarretar aumento ou diminuição de valores.

Como abordaremos no capítulo 3, a escolha de algumas ações também foi decorrência de embates entre os técnicos da prefeitura e do BID, ora cedendo às exigências do banco, ora fazendo prevalecer as intenções do governo. Outro fator de mudança foi a variação da cotação do dólar - moeda definida para o financiamento - diminuindo o montante de recursos em reais e servindo como justificativa para o corte de determinadas ações, em especial dos programas de habitação, assistência social e geração de emprego e renda. Esses cortes estão ocorrendo no atual governo (gestão Serra/Kassab 2005-2008), em conjunto com uma reestruturação do programa, acarretando alterações consideráveis que minimizaram ou eliminaram essas ações de cunho social e que buscavam garantir uma apropriação democrática do centro. O foco do programa se voltou para a área no bairro da Luz, conhecida como "cracolândia", onde a atual gestão está implementando o projeto Nova Luz, com vistas a criar um pólo de empresas de alta tecnologia.

Ao atentar para a tabela 1, percebemos que ações e intervenções que tinham objetivos similares seguindo o mesmo modelo de intervenção e gestão urbana - estavam locadas em componentes diferentes, ou ainda, que num mesmo componente foram inseridos subprogramas cujos objetivos eram divergentes. Esse último caso pode ser visto de forma mais explícita no componente “Reversão da Desvalorização Imobiliária e Recuperação da Função Residencial” (item 1 da tabela 1), em que foram agregados tanto mecanismos que pretendiam atrair investimentos privados (Projetos Motores e Operação Urbana Diagonal Sul) e, portanto gerar valorização imobiliária, como os programas de habitação de interesse social, cuja viabilização dependeria do controle público sobre os valores fundiários e imobiliários. Ainda que essas ações tenham se alinhado à mesma intenção de reverter o esvaziamento do centro, pautaram-se em princípios urbanísticos díspares, tinham objetivos divergentes e, como veremos na análise das ações, representaram diferentes modelos de desenvolvimento urbano. 
TABELA 1: COMPONENTES, CUSTOS E FINANCIAMENTO DO AÇÃo CENTRO ${ }^{31}$

\begin{tabular}{|c|c|c|c|c|c|c|}
\hline \multirow{4}{*}{$\begin{array}{l}\text { Subgrupo } \\
\text { de análise } \\
\text { (cores } \\
\text { conforme } \\
\text { gráfico 1) }\end{array}$} & \multicolumn{2}{|c|}{ Categoria de Investimento } & Banco & $\begin{array}{l}\text { Contrapartida } \\
\text { Local }\end{array}$ & Total & $\%$ \\
\hline & \multicolumn{2}{|c|}{ Investimento Direto } & 94.170.680,68 & $64.416 .898,89$ & 158.587.579,57 & $94,72 \%$ \\
\hline & \multicolumn{2}{|r|}{ Componente 1 Reversão da Desvalorização Imobiliária e Recuperação da Função Residencial } & $19.308 .031,43$ & $9.607 .045,43$ & $28.915 .076,86$ & $17,27 \%$ \\
\hline & 1.1 & Elaboração de propostas de legislação urbanística e tributária & $108.571,43$ & 0,00 & $108.571,43$ & $0,06 \%$ \\
\hline a & 1.1 .1 & Estudos urbanísticos especiais - Diagonal Sul - parte 1 & $51.428,57$ & 0,00 & $51.428,57$ & $0,03 \%$ \\
\hline \multirow[t]{2}{*}{ c } & 1.1 .2 & $\begin{array}{l}\text { Dinâmica Atual e Legislação Urbanística: Diagnóstico da Área Central; Legislação Urbanística; } \\
\text { Planos Diretores Regionais Subprefeitura Sé e Mooca }\end{array}$ & $57.142,86$ & 0,00 & $57.142,86$ & $0,03 \%$ \\
\hline & 1.2 & Intervenções Urbanísticas & $180.000,00$ & $2.707 .045,43$ & $2.887 .045,43$ & $1,72 \%$ \\
\hline a & 1.2 .1 & Projetos Motores - Trilha Histórica; Parque Urbano (Diagonal Sul - Parque Dom Pedro II) & $142.857,14$ & $2.707 .045,43$ & $2.849 .902,57$ & $1,70 \%$ \\
\hline $\mathrm{a}$ & 1.2 .2 & Concurso de Projeto Global Luz & $8.571,43$ & 0,00 & $8.571,43$ & $0,01 \%$ \\
\hline \multirow[t]{2}{*}{$\mathrm{a}$} & 1.2 .3 & Perímetros de Renovação Urbanística e Promoção Imobiliária - Estudos & $28.571,43$ & 0,00 & $28.571,43$ & $0,02 \%$ \\
\hline & 1.3 & Morar no Centro & $19.019 .460,00$ & $6.900 .000,00$ & $25.919 .460,00$ & $15,48 \%$ \\
\hline e & 1.3 .1 & Locação Social - Provisão e Reforma de Edifícios & $12.207 .062,86$ & 0,00 & $12.207 .062,86$ & $7,29 \%$ \\
\hline e & 1.3 .2 & Moradia Transitória & 0,00 & $1.185 .714,29$ & $1.185 .714,29$ & $0,71 \%$ \\
\hline $\mathrm{e}$ & 1.3 .3 & Programa PAR & 0,00 & $5.714 .285,71$ & $5.714 .285,71$ & $3,41 \%$ \\
\hline c & 1.3 .4 & Mecanismos de atração para famílias de renda média & $2.000 .000,00$ & 0,00 & $2.000 .000,00$ & $1,19 \%$ \\
\hline $\mathrm{e}$ & 1.3 .5 & Apoio técnico à recuperação de edifícios (São Vito) & $840.000,00$ & 0,00 & $840.000,00$ & $0,50 \%$ \\
\hline \multirow[t]{3}{*}{ e } & 1.3.6 & $\begin{array}{l}\text { PRIH - Perímetro de Reabilitação Integrada do Habitat (PRIH Luz; PRIH Glicério; PRIH } \\
\text { Brás) }\end{array}$ & $5.147 .279,86$ & 0,00 & $5.147 .279,86$ & $3,07 \%$ \\
\hline & \multicolumn{2}{|c|}{ Componente 2. Transformação do Perfil Econômico e Social } & $11.684 .481,38$ & $7.507 .142,86$ & $19.191 .624,24$ & $11,46 \%$ \\
\hline & 2.1 & Consultorias para criação da Agência de Desenvolvimento do Centro & 0,00 & $100.000,00$ & $100.000,00$ & $0,06 \%$ \\
\hline \multirow[t]{2}{*}{ c } & 2.1.1 & $\begin{array}{l}\text { Proposta de Estruturação Agência de Desenvolvimento da Área Central - Elaboração de } \\
\text { Decreto de Criação }\end{array}$ & 0,00 & $100.000,00$ & 0,00 & $0,00 \%$ \\
\hline & 2.2 & Divulgação do Programa & $857.142,85$ & $571.428,57$ & $1.428 .571,42$ & $0,85 \%$ \\
\hline \multirow[t]{2}{*}{$\mathrm{c}$} & 2.2.1 & $\begin{array}{l}\text { Campanha Publicitária do Centro - Elaboração de Material de Divulgação; Contratação de } \\
\text { Campanha de Rádio e TV }\end{array}$ & $857.142,85$ & $571.428,57$ & $1.428 .571,42$ & $0,85 \%$ \\
\hline & 2.3 & Regularização do Comércio Informal & $2.267 .545,14$ & $720.000,00$ & $2.987 .545,14$ & $1,78 \%$ \\
\hline d & 2.3 .1 & $\begin{array}{l}\text { Operação Trabalho e controle dos ambulantes - CERTA - Centro de Referência do } \\
\text { Trabalhador Ambulante }\end{array}$ & $1.017 .287,71$ & $685.714,29$ & 1.703.002,00 & $1,02 \%$ \\
\hline $\mathrm{d}$ & 2.3 .2 & Oportunidade Solidária - Central de Atividades Associativas e negócios Populares & $637.218,29$ & 0,00 & $637.218,29$ & $0,38 \%$ \\
\hline
\end{tabular}

31 Apresentamos neste trabalho a estrutura de ações e montantes de recursos que foi aprovada no contrato assinado com o BID em junho de 2004. Deve-se considerar que até o final do mesmo ano, foram realizadas alterações, cortes de ações ou mudanças de valores. Outra versão da listagem de ações (plano de aquisições) está disponível no site do BID, com data de janeiro de 2005, na qual o montante total do programa chega a US\$219 milhões. 


\begin{tabular}{|c|c|c|c|c|c|c|}
\hline d & 2.3 .3 & $\begin{array}{l}\text { São Paulo Inclui - CAS - Central de Atendimento Solidário; SAPT - Sistema de Alocação } \\
\text { pública de Trabalho; CAPTA - Central de Alocação do Trabalho Autônomo }\end{array}$ & $93.953,43$ & $34.285,71$ & $128.239,14$ & $0,08 \%$ \\
\hline $\mathrm{d}$ & 2.3 .4 & Capacitação Ocupacional - Aperfeiçoamento Profissional & $516.228,57$ & 0,00 & $516.228,57$ & $0,31 \%$ \\
\hline \multirow[t]{2}{*}{$\mathrm{d}$} & 2.3 .5 & Fortalecimento Institucional da SDTS & $2.857,14$ & 0,00 & $2.857,14$ & $0,00 \%$ \\
\hline & 2.4 & Segurança Pública & $1.176 .079,10$ & $571.428,58$ & $1.747 .507,68$ & $1,04 \%$ \\
\hline a & 2.4 .1 & Bases Comunitárias da Guarda Civil & $644.841,00$ & 0,00 & $644.841,00$ & $0,39 \%$ \\
\hline $\mathrm{a}$ & 2.4 .2 & Ocupação dos Espaços Públicos pela GCM - Aparelhamento da GCM & $207.666,68$ & $285.714,29$ & $493.380,97$ & $0,29 \%$ \\
\hline a & 2.4 .3 & Campanhas de Comunicação - Esclarecimentos e Divulgação do Centro Seguro & $91.428,57$ & $285.714,29$ & $377.142,86$ & $0,23 \%$ \\
\hline $\mathrm{a}$ & 2.4 .4 & Intercâmbio internacional - Formação dos Agentes da GCM & $75.000,00$ & 0,00 & $75.000,00$ & $0,04 \%$ \\
\hline \multirow[t]{2}{*}{$\mathrm{a}$} & 2.4 .5 & Pesquisa de Vitimização - Estudo de Violência no Centro & $157.142,85$ & 0,00 & $157.142,85$ & $0,09 \%$ \\
\hline & 2.5 & Atenção aos Grupos Vulneráveis & $7.383 .714,29$ & $5.544 .285,71$ & $12.928 .000,00$ & $7,72 \%$ \\
\hline $\mathrm{d}$ & 2.5 .1 & $\begin{array}{l}\text { Vetor A - Conhecimento da realidade - Levantamento Amostral de Moradores; Censo de } \\
\text { crianças e adolescentes em situação de rua (em toda a cidade de São Paulo); Avaliação do } \\
\text { funcionamento de toda a rede de atenção social do centro e sua demanda de atendimento; } \\
\text { Estudos dos usuários (crianças, adolescentes, adultos) dos albergues, abrigos e moradias } \\
\text { provisórias; Estudo da rejeçãa da população para acolhida em albergues; Auditorias externas } \\
\text { de resultados obtidos; Seminários e workshops }\end{array}$ & $714.285,71$ & 0,00 & $714.285,71$ & $0,43 \%$ \\
\hline $\mathrm{d}$ & 2.5 .2 & Vetor B - Presença social nas ruas com bases de apoio - Implementação de bases de apoio & $1.142 .857,14$ & 0,00 & $1.142 .857,14$ & $0,68 \%$ \\
\hline $\mathrm{d}$ & 2.5 .3 & $\begin{array}{l}\text { Vetor C - Destinação Social de próprios municipais desativados - Oficina Boracéa; Centro de } \\
\text { Jovens Prates; Rua dos Italianos }\end{array}$ & $3.747 .999,99$ & $2.322 .857,14$ & $6.070 .857,13$ & $3,63 \%$ \\
\hline d & 2.5.4 & $\begin{array}{l}\text { Vetor D - Qualificação da rede de proteção social - Qualificação da rede de serviços; } \\
\text { Qualificação da rede - Canindé }\end{array}$ & 1.028.571,43 & $685.714,28$ & $1.714 .285,71$ & $1,02 \%$ \\
\hline $\mathrm{d}$ & 2.5 .5 & $\begin{array}{l}\text { Vetor E - Expansão da rede de serviços da região central - Desabrigamento: fortalecendo o } \\
\text { convívio e o vínculo familiar; Estação Cidadania; Moradia Terapêutica }\end{array}$ & 0,00 & $571.428,57$ & $571.428,57$ & $0,34 \%$ \\
\hline d & 2.5.6 & $\begin{array}{l}\text { Vetor F - Fortalecimento Institucional - Qualificação da gestão de SAS no centro; Sistema de } \\
\text { vigilância da exclusão social, monitoramento de riscos sociais e defesa de mínimos sociais }\end{array}$ & $428.571,43$ & $1.000 .000,00$ & 1.428.571,43 & $0,85 \%$ \\
\hline $\mathrm{d}$ & 2.5 .7 & Vetor G - constante no componente 5 (fortalecimento institucional) & & & & \\
\hline \multirow[t]{3}{*}{ d } & 2.5 .8 & $\begin{array}{l}\text { Vetor H - Promoção da comunicação e do controle social da rede de proteção social - Loja } \\
\text { Social; Central de relacionamento com o cidadão (ã); Comunicação social }\end{array}$ & $321.428,57$ & $964.285,71$ & $1.285 .714,28$ & $0,77 \%$ \\
\hline & \multicolumn{2}{|c|}{ Componente 3. Recuperação do Ambiente Urbano } & $36.689 .919,63$ & $26.166 .337,10$ & $62.856 .256,73$ & $37,54 \%$ \\
\hline & 3.1 & Gestão de Operação e Manutenção & $1.428 .571,43$ & $3.902 .857,14$ & $5.331 .428,57$ & $3,18 \%$ \\
\hline $\mathrm{f}$ & 3.1 .1 & $\begin{array}{l}\text { Fortalecimento institucional da Subprefeitura Sé - Sistema de gestão da Subprefeitura; } \\
\text { Requalificação de Edifícios }\end{array}$ & $1.428 .571,43$ & $3.634 .000,00$ & $5.062 .571,43$ & $3,02 \%$ \\
\hline \multirow[t]{2}{*}{$\mathrm{f}$} & 3.1 .2 & Sistema de gestão de informação & 0,00 & $268.857,14$ & $268.857,14$ & $0,16 \%$ \\
\hline & 3.2 & Requalificação do Espaço Público & $8.829 .053,44$ & $6.249 .953,10$ & $15.079 .006,54$ & $9,01 \%$ \\
\hline a & 3.2 .1 & $1^{\circ}$ Grupo de obras & 0,00 & $1.766 .024,25$ & $1.766 .024,25$ & $1,05 \%$ \\
\hline $\mathrm{a}$ & 3.2 .2 & $2^{\circ}$ grupo de obras & $3.583 .824,83$ & $344.929,14$ & $3.928 .753,97$ & $2,35 \%$ \\
\hline $\mathrm{a}$ & 3.2 .3 & Reurbanização de Praças - República; Sé; Roosevelt & $2.390 .871,46$ & 0,00 & $2.390 .871,46$ & $1,43 \%$ \\
\hline $\mathrm{a}$ & 3.2 .4 & Projeto Piloto para Novo Calçadão & $628.571,43$ & 0,00 & $628.571,43$ & $0,38 \%$ \\
\hline
\end{tabular}




\begin{tabular}{|c|c|c|c|c|c|c|}
\hline a & 3.2 .5 & $\begin{array}{l}\text { Ruas Comerciais - Avenida Cásper Líbero; Santa Ifigênia; Rua do Gasômetro; Rua São } \\
\text { Caetano; } 25 \text { de Março e imediações (3.500 m); Gerenciamento das Ruas Comerciais }\end{array}$ & $2.066 .285,72$ & $970.857,14$ & $3.037 .142,86$ & $1,81 \%$ \\
\hline $\mathrm{a}$ & 3.2 .6 & Circuito Turístico de Compras - implementação & $135.000,00$ & $75.000,00$ & $210.000,00$ & $0,13 \%$ \\
\hline $\mathrm{a}$ & 3.2 .7 & Loja Cidade de São Paulo - Implementação do Centro de Informações Turísticas de São Paulo & $24.500,00$ & $9.500,00$ & $34.000,00$ & $0,02 \%$ \\
\hline \multirow[t]{2}{*}{$\mathrm{a}$} & 3.2 .8 & Iluminação do Centro - programa de iluminação da área central & 0,00 & $3.083 .642,57$ & $3.083 .642,57$ & $1,84 \%$ \\
\hline & 3.3 & Requalificação de Edifícios & 11.731.186,57 & $6.889 .301,44$ & $18.620 .488,01$ & $11,12 \%$ \\
\hline a & 3.3 .1 & Centro Eventos Palácio das Indústrias - Reforma do Palácio das Indústrias & $1.945 .000,00$ & 0,00 & $1.945 .000,00$ & $1,16 \%$ \\
\hline $\mathrm{a}$ & 3.3 .2 & Casa das Retortas - Reforma & $857.142,86$ & 0,00 & $857.142,86$ & $0,51 \%$ \\
\hline $\mathrm{a}$ & 3.3 .3 & Biblioteca Mário de Andrade - Modernização & $6.169 .043,71$ & $189.701,43$ & $6.358 .745,14$ & $3,80 \%$ \\
\hline $\mathrm{a}$ & 3.3 .4 & Edifício Martinelli - Reforma & $2.000 .000,00$ & $285.714,29$ & $2.285 .714,29$ & $1,37 \%$ \\
\hline $\mathrm{a}$ & 3.3 .5 & Teatro Municipal - Recuperação da fachada & $171.428,57$ & 0,00 & $171.428,57$ & $0,10 \%$ \\
\hline $\mathrm{a}$ & 3.3 .6 & Museu do Teatro Municipal - implantação & $171.428,57$ & 0,00 & $171.428,57$ & $0,10 \%$ \\
\hline $\mathrm{a}$ & 3.3 .7 & Revitalização Galeria Formosa & $57.142,86$ & 0,00 & $57.142,86$ & $0,03 \%$ \\
\hline $\mathrm{a}$ & 3.3 .8 & Casas Históricas - Reforma & $360.000,00$ & $57.142,86$ & $417.142,86$ & $0,25 \%$ \\
\hline \multirow[t]{2}{*}{$\mathrm{a}$} & 3.3 .9 & Mercado Municipal - Reforma & 0,00 & $6.356 .742,86$ & $6.356 .742,86$ & $3,80 \%$ \\
\hline & 3.4 & Controle de Inundações & $13.360 .217,15$ & $8.906 .811,43$ & $22.267 .028,58$ & $13,30 \%$ \\
\hline \multirow[t]{2}{*}{ a } & 3.4 .1 & $\begin{array}{l}\text { Melhorias no Sistema de Drenagem - Piscinão Pça. Bandeira; Piscinão Pça. } 14 \text { Bis + Galeria } 9 \\
\text { de Julho + Moringuinhos }\end{array}$ & $13.360 .217,15$ & $8.906 .811,43$ & 22.267.028,58 & $13,30 \%$ \\
\hline & 3.5 & Resíduos Sólidos Recicláveis & $1.340 .891,04$ & $217.413,99$ & $1.558 .305,03$ & $0,93 \%$ \\
\hline a & 3.5 .1 & Limpeza Urbana - melhoria & 0,00 & $28.628,57$ & $28.628,57$ & $0,02 \%$ \\
\hline $\mathrm{a}$ & 3.5 .2 & Central de Triagem - implantação & $532.223,14$ & $124.499,71$ & $656.722,85$ & $0,39 \%$ \\
\hline $\mathrm{a}$ & 3.5 .3 & Gestão de entulho - implantação & $808.667,90$ & 0,00 & $808.667,90$ & $0,48 \%$ \\
\hline \multirow[t]{3}{*}{ a } & 3.5 .4 & Feira Limpa - implantação & 0,00 & $64.285,71$ & $64.285,71$ & $0,04 \%$ \\
\hline & \multicolumn{2}{|c|}{ Componente 4. Transporte e Circulação } & $21.788 .130,86$ & $16.714 .286,28$ & $38.502 .417,14$ & $23,00 \%$ \\
\hline & 4.1 & Fortalecimento Institucional da SMT & $428.571,43$ & $142.857,71$ & $571.428,57$ & $0,34 \%$ \\
\hline $\mathrm{f}$ & 4.1.1 & $\begin{array}{l}\text { Desenvolvimento de Diretrizes e Estratégias para Sistema Integrado de Transporte Público } \\
\text { (SITP) }\end{array}$ & $28.571,43$ & $142.857,14$ & $171.428,57$ & $0,10 \%$ \\
\hline $\mathrm{f}$ & 4.1 .2 & Implantação Estratégica de fortalecimento institucional - formação de agentes públicos & $114.285,71$ & 0,00 & $114.285,71$ & $0,07 \%$ \\
\hline \multirow[t]{2}{*}{$\mathrm{f}$} & 4.1 .3 & $\begin{array}{l}\text { Desenvolvimento Metodologia Consolidação de Base de Dados; Implantação de Banco de } \\
\text { Dados }\end{array}$ & $285.714,29$ & 0,00 & $285.714,29$ & $0,17 \%$ \\
\hline & 4.2 & Circulação e Acessibilidade & 0,00 & $2.414 .285,71$ & $2.414 .285,71$ & $1,44 \%$ \\
\hline \multirow[t]{2}{*}{ b } & 4.2.1 & $\begin{array}{l}\text { Melhoria da circulação e micro-acessibilidade da Área Central - Projetos Funcionais da Área } \\
\text { Piloto e da Área de Interesse do programa (Anhangabaú); Projetos Executivos da Área Piloto } \\
\text { e da Área de Interesse; Implantação de Projetos }\end{array}$ & 0,00 & 2.414.285,71 & $2.414 .285,71$ & $1,44 \%$ \\
\hline & 4.3 & Operação de Trânsito e Melhoria do Sistema Viário & 6.976.416,57 & $857.142,86$ & $7.833 .559,43$ & $4,68 \%$ \\
\hline $\mathrm{a}$ & 4.3 .1 & Implantação de equipamentos eletrônicos de controle e monitoramento do trânsito & $2.014 .285,71$ & $285.714,29$ & $2.300 .000,00$ & $1,37 \%$ \\
\hline $\mathrm{a}$ & 4.3 .2 & Estratégia de monitoramento e controle de tráfego - melhoria no tráfego & $255.142,86$ & 0,00 & $255.142,86$ & $0,15 \%$ \\
\hline a & 4.3 .3 & Melhorias Viárias na Favela do Gato - implantação de novo sistema viário para acesso à área & $4.706 .988,00$ & $571.428,57$ & $5.278 .416,57$ & $3,15 \%$ \\
\hline
\end{tabular}




\begin{tabular}{|c|c|c|c|c|c|c|}
\hline & 4.4 & Transporte Público & 14.383.142,86 & $13.300 .000,00$ & $27.683 .142,86$ & $16,53 \%$ \\
\hline $\mathrm{b}$ & 4.4 .1 & Estudos de Acessibilidade & 0,00 & $42.857,14$ & $42.857,14$ & $0,03 \%$ \\
\hline $\mathrm{b}$ & 4.4 .2 & Intervenções da fase I - Projetos funcionais; Projetos Executivos; Obras de Implantação & $14.383 .142,86$ & $385.714,28$ & $14.768 .857,14$ & $8,82 \%$ \\
\hline $\mathrm{b}$ & 4.4 .3 & Intervenções da fase II - Projetos funcionais; Projetos Executivos; Obras de Implantação & 0,00 & $6.871 .428,57$ & $6.871 .428,57$ & $4,10 \%$ \\
\hline $\mathrm{b}$ & 4.4 .4 & Terminal Bandeira - Projetos funcionais; Projetos Executivos; Obras de Implantação & 0,00 & $4.428 .571,43$ & $4.428 .571,43$ & $2,65 \%$ \\
\hline $\mathrm{b}$ & 4.4 .5 & Equipamentos de apoio para operação dos terminais & 0,00 & $428.571,43$ & $428.571,43$ & $0,26 \%$ \\
\hline \multirow[t]{3}{*}{$\mathrm{b}$} & 4.4 .6 & Implantação de estações de transferência & 0,00 & $1.142 .857,14$ & $1.142 .857,14$ & $0,68 \%$ \\
\hline & \multicolumn{2}{|c|}{ Componente 5. Fortalecimento Institucional do Município } & $4.700 .117,38$ & $4.422 .087,22$ & $9.122 .204,60$ & $5,45 \%$ \\
\hline & 5.1 & Fortalecimento do Sistema de Planejamento Urbano do Município & $2.641 .057,05$ & $4.022 .087,22$ & $6.663 .144,27$ & $3,98 \%$ \\
\hline $\mathrm{f}$ & 5.1 .1 & $\begin{array}{l}\text { Fortalecimento Institucional da EMURB - Melhoria das instalações e infra-estrutura da } \\
\text { EMURB; Implementação de Sistema de Controle; Capacitação de Funcionários }\end{array}$ & $1.561 .707,42$ & $2.466 .709,72$ & 4.028.417,14 & $2,41 \%$ \\
\hline $\mathrm{a}$ & 5.1 .2 & Operação Urbana Diagonal Sul - Consultoria SEMPLA & $536.492,50$ & $926.806,07$ & $1.463 .298,57$ & $0,87 \%$ \\
\hline $\mathrm{f}$ & 5.1 .3 & $\begin{array}{l}\text { Fortalecimento do Geo-processamento de DEINFO - Implementação do Sistema de } \\
\text { Informações Geo-Processadas }\end{array}$ & 0,00 & $257.142,86$ & $257.142,86$ & $0,15 \%$ \\
\hline $\mathrm{a}$ & 5.1 .4 & $\begin{array}{l}\text { Mapeamento Infra-estrutura Urbana - Implantação do Sistema de Gestão de Infra-estrutura } \\
\text { Urbana }\end{array}$ & $142.857,14$ & $200.000,00$ & $342.857,14$ & $0,20 \%$ \\
\hline \multirow[t]{2}{*}{ a } & 5.1 .5 & $\begin{array}{l}\text { Projetos Ambientais - Sistema de Gerenciamento Ambiental; Plano Diretor de Vegetação } \\
\text { Urbana; Educação Ambiental }\end{array}$ & $399.999,99$ & $171.428,57$ & $571.428,56$ & $0,34 \%$ \\
\hline & 5.2 & Apoio à transferência de órgãos municipais para o Centro & $1.001 .722,29$ & $400.000,00$ & $1.401 .722,29$ & $0,84 \%$ \\
\hline $\mathrm{a}$ & 5.2 .1 & Centro de Estudos Jurídicos da PGM (CEJUR) - Reforma do CEJUR & $69.939,00$ & 0,00 & $69.939,00$ & $0,04 \%$ \\
\hline \multirow[t]{2}{*}{$\mathrm{a}$} & 5.2 .2 & Departamento Judicial/Patrimonial da PMSP (DEPATR) - Reforma DEPATR & $931.783,29$ & $400.000,00$ & $1.331 .783,29$ & $0,80 \%$ \\
\hline & 5.3 & Formação de gerentes sociais (INDES/SAS) & $1.057 .338,04$ & 0,00 & $1.057 .338,04$ & $0,63 \%$ \\
\hline \multirow[t]{11}{*}{$\mathrm{f}$} & 5.3.1 & Capacitação de funcionários - Qualificação de recursos humanos da rede de proteção social & $1.057 .338,04$ & 0,00 & $1.057 .338,04$ & $0,63 \%$ \\
\hline & \multicolumn{2}{|c|}{ Administração e Supervisão } & $5.242 .857,14$ & $2.593 .685,71$ & $7.836 .542,85$ & $4,68 \%$ \\
\hline & \multicolumn{2}{|c|}{ Administração e Supervisão } & 4.242.857,14 & $2.593 .685,71$ & $6.836 .542,85$ & $4,08 \%$ \\
\hline & & Gerenciamento do Programa - Contratação de Firma Gerenciadora & $3.871 .428,57$ & $2.171 .428,57$ & $6.042 .857,14$ & $3,61 \%$ \\
\hline & & Avaliação e Monitoramento do Programa & $371.428,57$ & $422.257,14$ & $793.685,71$ & $0,47 \%$ \\
\hline & & Consultoria Técnica Especializada para Avaliação Econômica do Programa & 0,00 & $79.400,00$ & $79.400,00$ & $0,05 \%$ \\
\hline & & Monitoramento Implantação do Programa & $371.428,57$ & $342.857,14$ & $714.285,71$ & $0,43 \%$ \\
\hline & \multicolumn{2}{|c|}{ Auditoria Externa - Contratação de Firma Auditora } & $1.000 .000,00$ & 0,00 & $1.000 .000,00$ & $0,60 \%$ \\
\hline & \multicolumn{2}{|c|}{ Custos Financeiros (FIV - 1\%) } & $1.000 .000,00$ & 0,00 & $1.000 .000,00$ & $0,60 \%$ \\
\hline & & TOTAL & 100.413.537,82 & 67.010.584,60 & 167.424.122,42 & $100,00 \%$ \\
\hline & & $\%$ & $59,98 \%$ & $40,02 \%$ & $100,00 \%$ & \\
\hline
\end{tabular}

Regulamento Operacional (PMSP/EMURB, 2004 d). 
Também é notável que ações voltadas à requalificação do ambiente urbano (melhoria da zeladoria, intervenções urbanísticas, soluções para enchentes, reforma de praças, melhoria de calçadas, iluminação, recuperação de edifícios, aumento da segurança, etc.), apareceram de forma espalhada nos diversos componentes. Acreditamos que essa organização das ações do programa confere certa dificuldade para sua análise, prejudicando a identificação e o entendimento de seus objetivos e estratégias, bem como dos diferentes pressupostos que o permearam. Como abordaremos ao longo desta dissertação, a tentativa de articulação das ações, sua heterogeneidade e mistura, demonstraram uma posição ambígua frente à recuperação da área central da cidade, na medida em que inseriu práticas díspares num mesmo discurso propositivo.

A fim de melhor identificar os diferentes princípios existentes nesse escopo, consideramos mais apropriado estruturar a análise do programa a partir do reagrupamento das ações que possuem princípios e objetivos iguais ou similares. Desse modo, estruturamos os seguintes subgrupos:

(a) melhoria do ambiente urbano, incluindo intervenções urbanísticas em espaços públicos, recuperação de edifícios - preservados por tombamento ou não -obras de drenagem, ações de zeladoria urbana, de inibição do comércio informal, de aumento da segurança e de melhoria do tráfego e da micro-acessibilidade;

(b) transporte público, considerando as propostas do Sistema Interligado de Transporte Público (SITP) para a área central;

(c) articulação com a sociedade civil e a iniciativa privada, abordando tanto as instâncias de gestão participativa como, os mecanismos criados para atração e estímulo aos investimentos privados, nos quais se inseriram a Agência de Desenvolvimento e as propostas relativas à atração de moradores de renda média;

(d) atenção aos grupos vulneráveis, envolvendo os programas de assistência social e de geração de emprego e renda voltados aos camelôs; e por fim,

(e) moradia social e manutenção da população de baixa renda, referente às modalidades de atendimento habitacional e às ações de gestão urbana integrada e participativa.

Além desses subgrupos, fizeram parte do escopo do programa as iniciativas de fortalecimento institucional (f) dos vários órgãos públicos envolvidos: Secretaria Municipal de Transportes, Secretaria Municipal de Assistência Social, Subprefeitura da Sé, EMURB, entre outros. Nesse caso, não consideramos apenas o que foi inserido no componente 5 ("Fortalecimento Institucional do Município"), mas também algumas das ações espalhadas pelos outros componentes, relativas à compra de equipamentos, implantação de banco de dados, formação de 
pessoal, entre outros. (ver tabela 1). Os custos de administração e auditoria também integraram o programa.

\section{TABELA 2: MONTANTES DE RECURSOS POR SUBGRUPO DE ANÁLISE}

\begin{tabular}{|c|c|c|}
\hline Subgrupo de Análise & Montante & $\%$ \\
\hline Melhoria do ambiente urbano & $75.429 .293,64$ & $44,95 \%$ \\
\hline Transporte Público & $27.683 .142,85$ & $16,50 \%$ \\
\hline Articulação com Iniciativa Privada & $3.585 .714,28$ & $2,14 \%$ \\
\hline Grupos Vulneráveis, emprego e renda para Comércio Informal & $15.915 .545,11$ & $9,49 \%$ \\
\hline Habitação Social & $25.094 .342,72$ & $14,96 \%$ \\
\hline Fortalecimento Institucional & $11.245 .755,18$ & $6,70 \%$ \\
\hline Outros (avaliação econômica, gerenciadora, monitoramento, auditoria) & $8.836 .542,85$ & $5,27 \%$ \\
\hline TOTAL & $167.790 .336,63 *$ & $100,00 \%$ \\
\hline
\end{tabular}

* O montante total de recursos é de 167,4 milhões de dólares. Há uma variação de montantes devido a alterações orçamentos, ocorridas após o detalhamento de algumas ações.

Fonte: Elaboração da autora a partir das informações da Tabela 1

GRÁfico 1: MONTANTES DE RECURSOS POR SUBGRUPO DE ANÁLISE

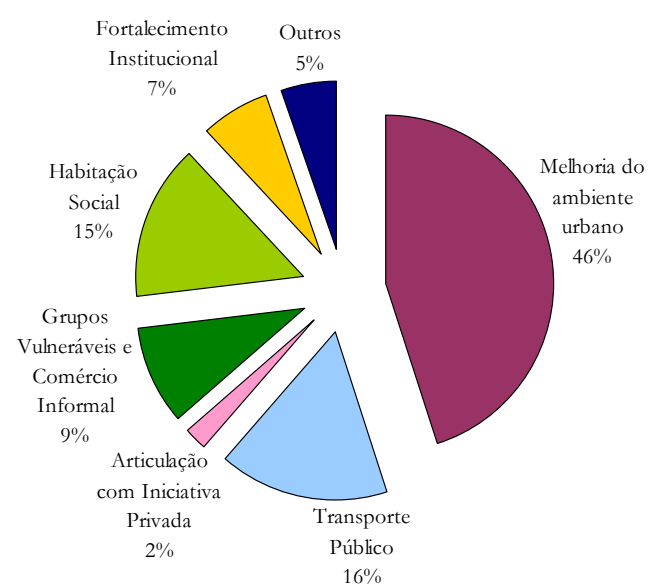

Fonte: Elaboração da autora a partir das informações da Tabela 1

\section{GRÁFICO 2: MONTANTES DE RECURSOS POR COMPONENTE}

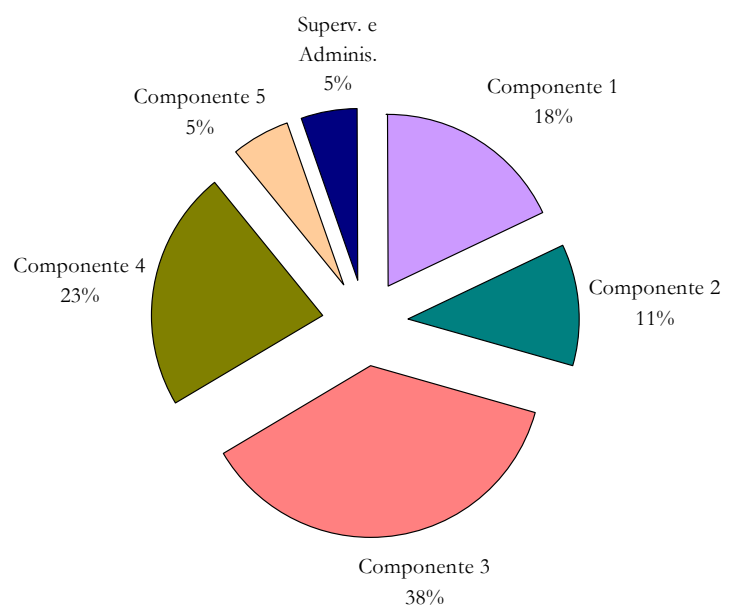

Fonte: Elaboração da autora a partir das informações da Tabela 1 
Ao atentarmos para o gráfico 2, percebemos que o componente 3 ("Recuperação do Ambiente Urbano", segundo tabela 1) possuía maior peso dentro do total de recursos do programa (37,54\%), o que mostra a importância dada às obras de infra-estrutura (drenagem), em edifícios e espaços públicos. Da mesma forma, na organização em subgrupos proposta por nós (tabela 2 e gráfico 1), é possível perceber o peso das ações relacionadas à melhoria do ambiente urbano, que envolvem o componente 3 , representando quase $46 \%$ do total de recursos do programa (cerca de 75,4 milhões de dólares), sendo as obras de drenagem o conjunto de ações de maior peso dentro do subgrupo (13,30\%). Se excluíssemos as obras de drenagem, o subgrupo ainda representaria cerca de $30 \%$ do total de recursos do programa, mais do que o destinado à habitação social (15\%) e ao transporte público $(16,5 \%)$.

Por fim, vale destacar que, de acordo com o Regulamento Operacional, as ações do programa foram dividas em dois grupos distintos: ações específicas e ações múltiplas. As ações consideradas múltiplas eram "projetos amostrais", que ainda não possuíam especificações detalhadas da área ou edifício em que ocorreriam, nem da dimensão de seu público alvo, sendo em sua maioria relativa à habitação social. Elas deveriam ser avaliadas de acordo com os Critérios de Elegibilidade do programa - técnico-legais, sócio-econômicos, financeiro/institucional e sócio-ambientais - recebendo a declaração de "não-objeção", a fim de serem contempladas com recursos do financiamento ou da contrapartida. Já as ações específicas cumpriam de antemão esses critérios, consideradas de "caráter estruturante, emblemático" ou que "contribuem para a materialização dos objetivos fundamentais do programa" (PMSP/EMURB, 2004d). Em sua maioria, as ações específicas eram aquelas relativas à melhoria do ambiente urbano: requalificação de espaços e edifícios públicos, melhoria de infra-estrutura (drenagem, transporte e circulação), controle do comércio informal, zeladoria urbana e aumento da segurança pública (anexo 3).

Percebe-se, portanto, que a amarração das ações do programa se deu de forma complexa, abarcando diversos campos de trabalho e conhecimento. Nesta pesquisa destacamos aquelas de maior relevância para o alcance de seus objetivos - "promover o desenvolvimento social e econômico com diversidade" - e as que mais explicitaram os diferentes modelos de intervenção e gestão urbana adotados. Relembramos que o escopo de ações foi alterado diversas vezes entre a assinatura do contrato e o final da gestão Marta Suplicy em 2004 e, novamente, com a mudança de governo em 2005. 


\subsubsection{MELHORIA DO AMBIENTE URBANO: UM MECANISMO INDUTOR DA TRANSFORMAÇÃO}

O discurso dominante da recuperação de áreas degradadas - entre elas os centros urbanos históricos - afirma que a atração de capital privado é a única estratégia possível para sua revitalização ou requalificação, instalando empresas e investindo em empreendimentos imobiliários. Essa estratégia, por sua vez, necessita de intervenções públicas prévias focadas na melhoria ambiental, o que inclui desde pequenas ações de manutenção de espaços públicos e aumento da segurança, até modernização da infra-estrutura e implantação de projetos urbanísticos ou arquitetônicos de porte, esses últimos entendidos como "alavanca" do processo de revitalização, nos moldes do chamado planejamento estratégico (ARANTES, 2000; VAINER, 2000; FIX, 2000; FERREIRA, 2007).

O Programa Ação Centro também se embasou nessa idéia, já que para alcançar seu objetivo de "promover o desenvolvimento social e econômico com diversidade da Área Central" (PMSP/EMURB, 2004a), foi considerado necessário realizar um conjunto de melhorias do ambiente urbano. Propôs ações de limpeza e manutenção, requalificação de edifícios e espaços públicos existentes - tombados ou não - aumento da segurança, controle do comércio ambulante, aumento da acessibilidade por automóveis, reorganização do transporte público e solução para os problemas de enchentes. Ações essas que pretendiam melhorar o ambiente urbano e reverter a desvalorização simbólica do centro, pré-requisitos para que setores da iniciativa privada e classes de maior poder aquisitivo voltassem a se interessar pelo mesmo.

Vários especialistas e agentes do mercado defendem a hipótese segundo a qual a volta de famílias de classe média dependerá fundamentalmente dos resultados das ações de melhoria dos espaços públicos e de zeladoria (coleta de lixo, manutenção, segurança, etc.). (PMSP/SEHAB/COHAB/Morar no Centro, 2004)

Dessa forma, a realização de grande parte dos subprogramas do Ação Centro seria um mecanismo indutor da atração de capital privado, na medida em que daria ao centro os quesitos necessários para a "alavancagem" de sua recuperação. A idéia ainda seria criar um "ambiente favorável" ao estabelecimento de pessoas e atividades econômicas no centro (SOMEKH, 2004a, p.85), embora a própria coordenadora do programa tenha ponderado essa abordagem ${ }^{32}$, reconhecendo as análises críticas já elaboradas. Tal intenção pode ser notada no componente 2 (Transformação do Perfil Econômico e Social) que, como aponta Somekh (2004b, p.4), "referese a ações relacionadas à promoção do desenvolvimento econômico e social local". A autora destaca o meio pelo qual este desenvolvimento seria alcançado:

32 Somekh, Nádia. Em entrevista cedida à autora em janeiro de 2008. 
Isto seria possível por meio da criação de incentivos para a renovação do tecido produtivo, criando um pólo de atração de micro e pequenas empresas não poluentes e, especialmente, empresas do setor terciário de alta tecnologia. Nesse sentido, foram traçadas as seguintes estratégicas: desenvolvimento de consultorias para a criação do mecanismo de articulação com o setor privado; divulgação do Programa de Reabilitação da área Central; regularização do comércio informal e atenção aos grupos vulneráveis. (SOMEKH, 2004b, p.4, grifos nossos)

Vê-se que diversas ações que integraram este componente possuíam caráter indutor da melhoria do ambiente urbano: as ações de controle e inibição do comércio informal, associadas ao policiamento preventivo realizado pela Guarda Civil Metropolitana (GCM), e as iniciativas de redução do clima de insegurança através da instalação de bases comunitárias, aparelhamento, aumento do efetivo e formação dos agentes da Guarda, as quais estão descritas no Regulamento Operacional do programa (PMSP/EMURB, 2004d).

O comércio informal de ambulantes foi entendido como fator de degradação e, portanto, elemento dificultador da recuperação da área central da cidade; uma idéia que se fortaleceu a partir dos anos 90, inclusive através dos debates promovidos pela Associação Viva o Centro, mencionados anteriormente. A despeito das questões macroeconômicas de desemprego, diretamente relacionadas ao aumento do número de trabalhadores informais, entre eles os camelôs, sua atividade levantou questões no âmbito do Programa Ação Centro referentes à apropriação do espaço público, às condições de limpeza e aos conflitos com o comércio formalmente estabelecido (SILVA, 2004). O Informe de Proyecto, documento assinado por técnicos do $\mathrm{BID}^{33}$, aponta que a regularização e o ordenamento do comércio informal de rua não implicarão em sua expulsão da área central (BID, 2004a, p.23, item 4.21).

No entanto, mostrando uma visão muito similar àquela da Viva o Centro - destacada anteriormente - o mesmo documento apontou que a "população ${ }^{34}$ vê nesta presença [de comerciantes informais e também de moradores de rua] uma ameaça a sua segurança pessoal, evitando utilizar estas áreas, gerando um ciclo vicioso difícil de romper” (BID, 2004a, p. 4, item 1.13). Neste sentido, a relocalização das atividades informais e a inibição de sua presença em determinadas ruas, especialmente na Área de Interesse do programa, associadas às ações de aumento do policiamento (instalação de bases comunitárias da GCM), seriam fundamentais para tornar o centro um espaço atrativo para novos usos e freqüentadores. Tais ações representaram,

\footnotetext{
33 Em parte, este documento foi escrito em conjunto com os gestores públicos locais, segundo Luis Octávio da Silva, em entrevista cedida à autora em janeiro de 2008.

34 No documento não foi especificada qual população, dando a entender que se trata da população da cidade, de maneira geral. Ou ainda, da população que se quer atrair para o centro, de maior poder aquisitivo, como veremos ao longo deste trabalho.
} 
portanto, uma iniciativa determinante para a melhoria do ambiente urbano, para a construção do “ambiente favorável” aos investimentos privados.

As ações do componente 3 (Recuperação do Ambiente Urbano) também se voltavam para a construção deste "ambiente favorável". Como consta na tabela 1, essas ações eram: (i) sistema de gestão e zeladoria do centro, através do fortalecimento institucional da Subprefeitura Sé e da melhoria das ações de limpeza e manutenção; (ii) requalificação de equipamentos, infra-estrutura e espaços públicos, incluindo reforma de calçadas e do mobiliário urbano, melhoria da iluminação, reordenamento de ruas comerciais, criação de um circuito turístico de compras e de uma central de informações turísticas, delimitação de tráfego de veículos em trechos de calçadão, obras de drenagem para evitar enchentes no Anhangabaú, reformas das praças da Sé, República e Roosevelt; e (iii) recuperação e reciclagem de edifícios históricos, como Biblioteca Mário de Andrade, Mercado Municipal, Edifício Martinelli, Palácio das Indústrias, Casa das Retortas, Casa n. 1, Solar da Marquesa, Beco do Pinto, Museu e Teatro Municipal.

Segundo o Regulamento Operacional do Programa (PMSP/EMURB, 2004d), "este componente destina-se a criar condições de suporte para as ações de manutenção e requalificação do espaço público e de monumentos deteriorados e de requalificação de edificações". As ações que o compõem seriam, portanto, fundamentais para a melhoria dos espaços e edifícios públicos da área central, podendo beneficiar todos os moradores e freqüentadores do centro.

No entanto, deve-se atentar para o entendimento - apresentado pelos materiais oficiais do programa - de que essas intervenções urbanísticas e ações de zeladoria seriam elementos fundamentais para que setores da iniciativa privada investissem na área, instalando novas empresas e atividades, e realizando empreendimentos imobiliários de uso terciário e residencial. Tanto no documento elaborado por técnicos do BID em outubro de 2003 - momento de aprovação do programa - como em sua versão revisada após a assinatura do contrato em outubro de 2004, se destaca que "a recuperação do ambiente urbano é considerada como um dos eixos fundamentais da estratégia de mudar o perfil econômico e as funções do centro, assim como da qualidade de vida dos que vivem, trabalham e utilizam o centro" (BID, 2004a, p.8, grifos nossos).

Ao lado dessas ações, os pontos-chave do ideário da melhoria do ambiente urbano como mecanismo de atração de investimentos privados foram os Projetos Motores, integrante do componente 1 (Reversão da Desvalorização Imobiliária e Recuperação da Função Residencial). Nos moldes do chamado planejamento estratégico, esses projetos foram apresentados como forma de induzir uma mudança de usos na área central (BID, 2004a). Segundo Silva (2005), 
foram enfocadas áreas específicas e consideradas estratégicas, que receberiam estes projetos motores, em especial a região do Parque Dom Pedro II e a área do Centro Velho e Centro Novo - a chamada Área de Interesse (distritos Sé/República).

Serão financiadas obras estratégicas de recuperação de grandes áreas urbanas. Esses espaços serão indutores da alteração de usos do Centro. A etapa contempla, por exemplo, a reabilitação e a reforma do Parque Dom Pedro II - que retomará seu perfil de pólo de lazer, cultura e eventos - e os estudos arquitetônicos e os projetos de renovação das áreas cerealista e madeireira, localizadas no Parque, em uma zona com forte vocação para abrigar edifícios inteligentes, tanto para escritórios como para residências. (SOMEKH, 2004b, p.2, grifos nossos)

As intervenções urbanísticas previstas para a área do Parque Dom Pedro II estavam relacionadas com as diretrizes da Operação Urbana Diagonal Sul (OUDS) $)^{35}$ que, segundo os documentos do programa, se embasavam no contexto obsolescência e perda da função industrial da metrópole paulistana, em especial ao longo do vale do Tamanduateí, onde se localiza essa operação (SALES, 2004). Numa área caracterizada pela concentração de antigos galpões industriais subutilizados e entendida como de "grande potencial para a promoção imobiliária" (SILVA, 2004, p.32), a intenção do projeto era dar um novo uso, investindo em centros de entretenimento e lazer voltados para público de mais alta renda (PMSP/EMURB, 2004b, p.5), e atraindo a instalação de escritórios e residências para diversas rendas nas atuais zonas cerealista e madeireira. Ainda que a totalidade do projeto não tenha sido concretizada, essa área foi apresentada como prioritária para as intervenções do programa, canalizando uma considerável fatia dos recursos e representando um "vetor de irradiação da reabilitação do Centro em direção à Zona Leste da cidade e à região do ABC” (SILVA, 2004, p.32), em associação à implantação da Operação Diagonal Sul.

O projeto contou com ações inseridas em outros 3 componentes, principalmente no de Recuperação do Ambiente Urbano, envolvendo a contratação de estudos urbanísticos e

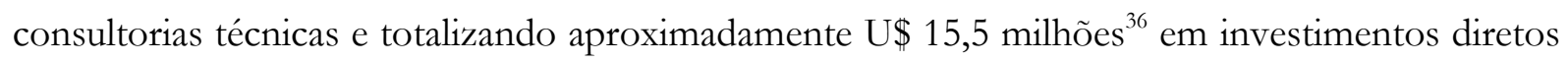
(9,30\% do total de recursos do programa). Entre as ações que buscavam a criação de um “ambiente favorável” para a atração de capital privado, destacavam-se: restauro do Mercado

\footnotetext{
35 A OUDS foi prevista no texto do Plano Diretor Estratégico do Município, aprovado em 2002, necessitando de regulamentação específica para ser implementada. Em dezembro de 2002 foi entregue relatório contendo diagnósticos e propostas de diretrizes para essa operação urbana, elaborado por consultoria da FUPAM - Fundação para a Pesquisa Ambiental, contratada pela EMURB. Participaram dessa consultoria os arquitetos/urbanistas Wilson Jorge, Eduardo Nobre, Flávio Villaça, Heliana Comin Vargas e Paulo Pellegrino, além do economista Gustavo Zimmerman e do engenheiro Celso Contro di Celio. A EMURB deu continuidade a esses estudos e contratou uma consultoria da SEMPLA - Secretaria Municipal de Planejamento (Plano-referência de intervenção e ordenação urbanística - PRIOU), inserindo alguns dos projetos propostos no escopo do Ação Centro.

${ }^{36}$ Esse montante de recursos envolvia as ações diretas e localizadas na área do Parque e em suas imediações: estudos urbanísticos e consultoria técnica para a Operação Urbana Diagonal Sul e outros projetos, intervenções em ruas comerciais (25 de Março e Gasômetro), recuperação dos edifícios (Mercado Municipal, Palácio das Indústrias, Casa das Retornas, São Vito) e espaços públicos (Parque Urbano = Parque Dom Pedro II). Não foram considerados gastos dispersos referentes a subprogramas que eventualmente poderiam realizar ações na área. Se considerarmos os custos referentes à implantação do PRIH Brás, que se localizava em frente ao Parque, o montante de recursos sobe para U\$17,1 milhões.
} 
Municipal; adaptação da Casa das Retornas e do Palácio das Indústrias para abrigar o Museu da Cidade, com a transferência do gabinete da Prefeita para edifício no Viaduto do Chá; recuperação do Edifício São Vito; e requalificação do Parque Dom Pedro II, com resgate de sua função de área verde ${ }^{37}$ (SILVA, 2004) e buscando melhor integração e condições de travessia de pedestres.

O Edifício São Vito foi apresentado como parte desse projeto e da OUDS, ao mesmo tempo em que integrava os programas de atendimento habitacional como um projeto especial, apesar de não finalizado. O projeto para esse edifício - desapropriado pelo poder público - visava sua reabilitação para habitação de interesse social, com unidades destinadas aos moradores originais, que foram removidos e receberam o auxílio da Bolsa Aluguel para o período de realização das obras. Voltaremos a discutir o caso do São Vito mais adiante, mas cabe destacar aqui que o projeto foi totalmente paralisado a partir da mudança do governo municipal em 2005, inclusive com a suspensão da bolsa aluguel das famílias removidas e cogitando-se sua demolição.

Até o final da gestão Marta Suplicy, as ações concretizadas foram: execução de parte das obras do Mercado Municipal, saída da sede da Prefeitura do Palácio das Indústrias e sua transferência para o Edifício Matarazzo no Viaduto do Chá, início das ações no edifício São Vito com a remoção das famílias, e algumas intervenções de melhoria na Rua 25 de Março, como projeto amostral do Programa de Ruas Comerciais.

As intervenções realizadas no Mercado Municipal são representativas das intenções do projeto para a área do Parque Dom Pedro II, uma vez que, a nosso ver, seus efeitos geraram a intensificação do uso turístico e transformação do perfil de freqüentadores. Contou com obras de restauro dos elementos arquitetônicos - vitrais, adornos, pilares hidráulicos etc.; reforma da cobertura e do sistema de drenagem; subsolo de serviços e apoio com execução da infra-estrutura necessária - coleta de esgoto e abastecimento de água; reorganização dos estacionamentos; e construção de um mezanino para receber o chamado Centro Gastronômico, potencializando o uso turístico. O projeto previa ainda intervenções viárias para melhorar a acessibilidade e a reestruturação da área de carga e descarga, o que não foi executado.

Além das intervenções no Parque Dom Pedro II e seu entorno, a Trilha Histórica (mapa 3) também foi apresentada como um Projeto Motor (tabela 1). Como parte das ações incidentes sobre a Área de Interesse do programa, sua proposta era criar um percurso que integrasse as Casas Históricas (Casa n. 1, Solar da Marquesa, Beco do Pinto) e demais edifícios tombados no Centro Velho (Edifício Martinelli, por exemplo) com o Museu da Cidade, cuja sede seria abrigada

37 A idéia seria recuperar as áreas "perdidas" ao longo dos anos, desde a implantação parcial do projeto elaborado por Joseph Antoine Bouvard em 1910, para as intervenções viárias, complexos de viadutos e de equipamentos de transporte. 
no Palácio das Indústrias, restaurado e adaptado para esse uso. A Trilha compunha um projeto museológico de visitação ao patrimônio histórico, prevendo instalação de sinalização turística, reforma de calçadas e ordenamento do mobiliário urbano - nos moldes do Corredor Cultural, proposto ainda no âmbito do Plano Reconstruir o Centro, como mencionado.

Para o Edifício Martinelli, por exemplo, estava previsto um projeto de reforma e melhoria, envolvendo a instalação de um restaurante/mirante em seu terraço - de propriedade da EMURB. No entanto, a implantação da "Trilha Histórica" e as reformas do Edifício Martinelli, das Casas Históricas e do Palácio das Indústrias não chegaram a ser realizadas.

MAPA 3: TRILHA Histórica

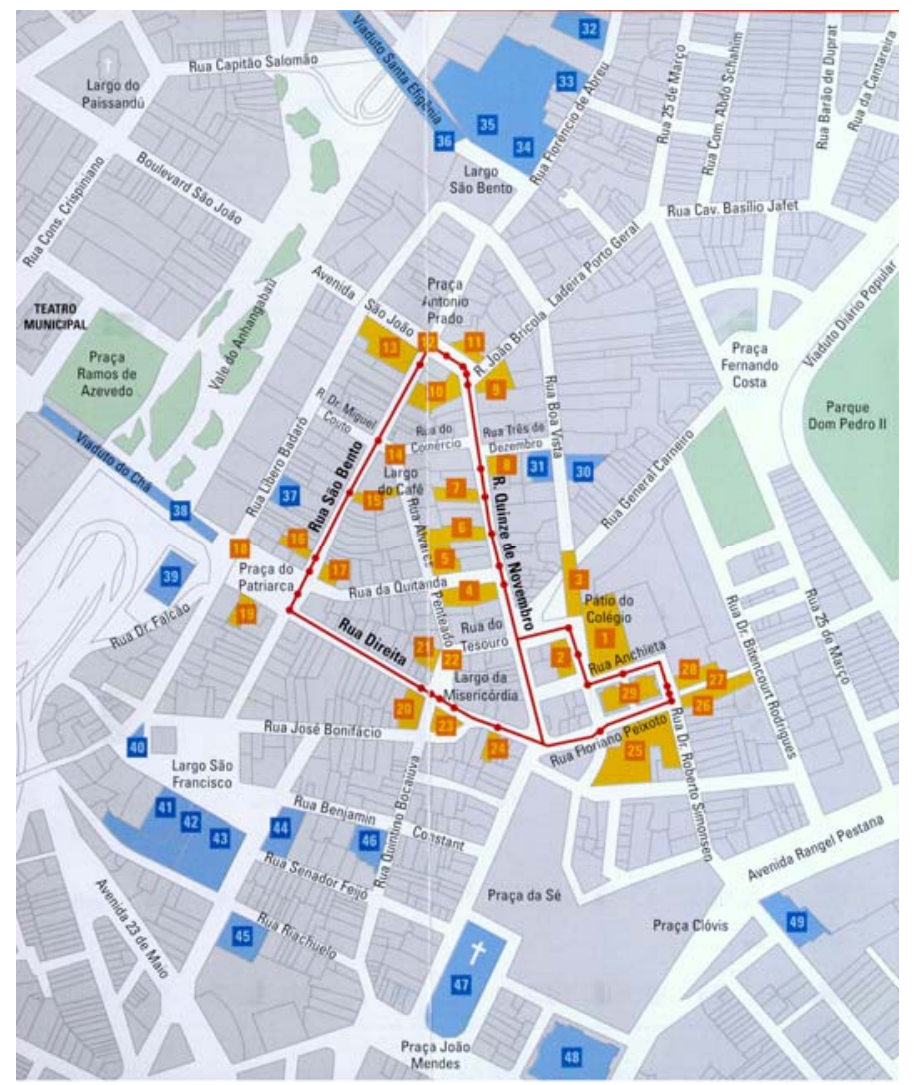

Fonte: PMSP/EMURB, 2004a.

Ao propor a Trilha Histórica como Projeto Motor, associando-a ao Museu da Cidade, o Ação Centro mostrou um alinhamento ao ideário das “intervenções urbano-culturais” (KARA-JOSÉ, 2007), em que se acredita que a almejada transformação no perfil de uso e ocupação será alcançada através de "projetos-culturais-âncora" - de preferência com baixo custo - da animação turístico-cultural e conseqüente atração de novos freqüentadores e investimentos privados. Não negamos a importância de preservar e recuperar edifícios de valor histórico, como parte da memória paulistana, dando-lhes uma apropriação cotidiana e inserindo-os na dinâmica de usos da 
cidade. No entanto, pautando-se nos princípios do chamado planejamento estratégico - que trataremos no capítulo 3 - tais projetos motores serviriam como "alavanca" para a revitalização e valorização do centro, resultando na expulsão da população de baixa renda moradora e usuária da área central. Além disso, importante destacar que a preservação do patrimônio histórico deve considerar também os conjuntos construídos e o tecido social existente - inclusive a população de baixa renda - ampliando o conceito e extrapolando o tratamento isolado de edifícios monumentais, como já o fizeram governos locais de países centrais do capitalismo. No capítulo 3 abordaremos algumas experiências realizadas nestes países que se pautaram numa noção ampliada de patrimônio histórico, procurando recuperar o conjunto edificado e manter a população moradora de baixa renda de bairros centrais que passavam por processos de reabilitação urbana.

A preservação do patrimônio histórico não ganhou um componente específico no Programa Ação Centro, mas permeou vários deles. É o caso de dois edifícios que passaram por obras de recuperação e adaptação, a fim de abrigar órgãos públicos que se transferiram para o centro: o prédio do CEJUR (Departamento Jurídico), localizado na Avenida Brigadeiro Luís Antonio, e o PATR (Departamento Patrimonial), localizado na Avenida Liberdade, considerados parte do componente 5 (Fortalecimento Institucional do Município). Vale lembrar que a iniciativa de transferir secretarias e órgãos públicos para edifícios centrais sempre foi defendida no contexto da revitalização do centro, uma vez que a forte presença de funcionários públicos na área, aumentando a demanda por comércios e serviços, pode contribuir para a dinamização da economia local. Pode-se perceber essa idéia em publicações da Viva o Centro ${ }^{38}$, contribuindo para a consolidação da idéia dominante de recuperação de áreas centrais.

Outras intervenções foram propostas para a Área de Interesse - área estratégica para a realização de Projetos Motores (SILVA, 2004) - buscando a revalorização simbólica da área e a reversão de sua degradação, como apontado pelos documentos oficiais do programa. Eram as ações de zeladoria urbana e requalificação de espaços públicos integrantes do componente 3 (Recuperação do Ambiente Urbano). A nosso ver, mesmo sem a denominação de Projeto Motor, essas ações e intervenções também contribuíram para a estratégia de estimular os investimentos privados.

As reformas das praças da Sé, República e Roosevelt podem ser consideradas os exemplos mais significativos dessa estratégia, servindo à construção do necessário “ambiente favorável” para a recuperação da área central. As duas primeiras tiveram suas obras iniciadas apenas em 2006 e foram inauguradas em janeiro e fevereiro de 2007, durante a atual gestão municipal, sendo foco

38 Ver "Revista URBS” de maio/junho de 1999. 
de várias polêmicas entre técnicos do poder público, urbanistas e movimentos sociais, como no caso da instalação de câmeras de segurança e de bancos "anti-mendigo" 39. Já a reforma da Praça Roosevelt ainda não foi executada e teve seu projeto questionado em função da proposta de demolição do "pentágono" (estrutura de concreto que configura uma praça elevada em sua cobertura), entendida por alguns grupos e movimentos sociais como fator de expulsão dos moradores de rua que ocupam o local ${ }^{40}$. Todas essas reformas foram objetos de reivindicação das Ações Locais - associações de moradores e comerciantes organizados pela Viva o Centro ${ }^{41}$.

Também localizado na Área de Interesse, o projeto Corredor Cultural foi proposto pelo Plano Reconstruir o Centro (2001) e realizado durante a gestão Marta Suplicy como um projeto piloto de "fruição cultural". Realizado com recursos da Operação Urbana Centro, esse projeto não constou na listagem de ações (tabela 1), mas teve considerável importância no conjunto de intervenções urbanísticas e de melhoria do ambiente construído do centro. Constituído de um eixo entre a Praça Dom José Gaspar (Biblioteca Mario de Andrade) ${ }^{42}$ e a Praça do Patriarca passando pela Rua Xavier de Toledo, Ladeira da Memória, Viaduto do Chá e Teatro Municipal o Corredor Cultural envolveu tratamento paisagístico, iluminação, sinalização, troca de piso, aumento da largura de calçadas, reorganização do mobiliário urbano e dos pontos de ônibus.

As reformas das Praças Dom José Gaspar e do Patriarca também compuseram este projeto, nas extremidades do eixo. A primeira foi uma intervenção de menor porte, mantendo a organização dos espaços existentes e realizando troca de piso, paisagismo, iluminação etc. Já a segunda alterou a relação da Praça do Patriarca com o entorno ao realizar seu fechamento para veículos, remoção do terminal de ônibus existente e construção do pórtico/cobertura na entrada da Galeria Prestes Maia - transformada no MASP Centro.

De autoria do arquiteto Paulo Mendes da Rocha, o projeto Pórtico Patriarca foi encomendado pela Associação Viva o Centro (AVC) durante a gestão municipal de Paulo Maluf (1993-1996), sendo apresentado como integrante do PROCENTRO de 1993. Sua execução foi importante dentro do conjunto de intervenções indutoras do Programa Ação Centro, dialogando com os interesses da AVC, que defende a melhoria de espaços públicos como estratégia para a

\footnotetext{
39 Sobre a Praça da República, ver reportagens da Folha de São Paulo, caderno Cotidiano, de 22 de fevereiro de 2007 e as repercussões no Painel do Leitor, Editorial e Cotidiano dos dias 23 e 26 do mesmo mês. A Praça da Sé foi inaugurada no aniversário da cidade, em 25 de janeiro de 2007, em evento marcado por manifestações de movimentos sociais relacionados à questão da habitação e de moradores de rua. Ver caderno Cotidiano de 25 de janeiro de 2007.

40 Até o final de 2007, os usos e atividades que ocupavam a parte de baixo do "pentágono" da Praça Roosevelt foram removidos, indicando o possível início das obras de reforma.

41 Ver "Informes Viva o Centro", em especial de março de 2006 e novembro e fevereiro de 2007.

$42 \mathrm{O}$ restauro e modernização da Biblioteca Mario de Andrade integraram o escopo do financiamento do BID, sendo que suas obras foram iniciadas em setembro de 2007.
} 
redinamização econômica do centro, como apontado anteriormente. Tal projeto tornou-se, inclusive, a logomarca do programa.

Essa reforma também ocorreu em meio a diversas polêmicas entre movimentos sociais, urbanistas, técnicos do poder público e interessados na revitalização do centro em geral, uma vez que, ao remover o terminal de ônibus, acarretou a expulsão dos comerciantes informais que ocupavam o local e inibiu a presença de moradores de rua. Sem qualquer tipo de consulta à população, o projeto foi imposto à cidade, mostrando, ao lado de outras propostas do programa, a faceta antidemocrática das ações da recuperação do centro. Depois de finalizadas as obras, a praça passou a ser constantemente policiada, inibindo sua reocupação por comerciantes informais, ainda que, por estar localizada em frente ao gabinete do Prefeito, seja palco para manifestações populares, como no recente caso das reivindicações de moradores removidos da vizinhança de um condomínio de alto padrão em construção nas margens do Rio Pinheiros ${ }^{43}$.

Nota-se que o tratamento da questão dos comerciantes informais foi recorrente nas ações da Prefeitura voltadas para o centro, condizentes ao objetivo de melhorar o ambiente urbano para atrair investimentos privados. Abarcando parte dos programas da Secretaria de Trabalho e da Secretaria de Segurança Pública, em ações conjuntas, este subcomponente do Ação Centro enfocou, de um lado, a realização de programas de capacitação profissional, formação de cooperativas e empréstimos para montagem de estabelecimentos comerciais - que abordaremos adiante - e de outro, ações restritivas e repressivas por parte da Guarda Civil Metropolitana.

Previa campanhas contra a compra de produtos ilegais - contrabando e pirataria - e ações de controle, fiscalização e policiamento dos espaços públicos, inibindo o exercício da atividade. A vinculação do aumento da segurança pública - implantação de bases comunitárias pelo programa "Centro Seguro" - com o controle do comércio ambulante era clara: "a idéia é reforçar o policiamento preventivo e garantir que determinadas ruas mantenham-se livres da presença de ambulantes" (SOMEKH, 2004b, p.5). Percebe-se nos documentos analisados, que o caráter das ações propostas foi decorrência da associação generalizada dos trabalhadores informais com as atividades ilícitas do contrabando de mercadorias.

Voltaremos a tratar destas ações mais adiante, mas cabe destacar que o conjunto de ações voltadas ao comércio ambulante vestiu-se de um caráter ambíguo. Encontramos nos documentos do programa discursos argumentativos que ora defendiam a repressão dos ambulantes e sua

\footnotetext{
43 Refiro-me ao caso da remoção da favela Real Parque no Morumbi, localizada ao lado da nova ponte estaiada que está sendo construída na Marginal Pinheiros na altura da Avenida Roberto Marinho (Águas Espraiadas), e que sofreu ação de despejo em novembro de 2007 .
} 
retirada da área - em especial da Área de Interesse - justificadas em sua estreita relação com a ilegalidade; e ora ressaltavam a importância de garantir aos trabalhadores informais melhores condições de vida através dos programas de capacitação, micro-crédito, entre outros, abordando a complexidade da questão da informalidade.

Ressaltamos, novamente, que não se pretende negar a importância de alguns dos projetos e intervenções que constaram no Programa Ação Centro, como a preservação do patrimônio histórico e da memória, o tratamento dos equipamentos e mobiliários urbanos e a melhoria dos espaços públicos, caso sua execução atenda o conjunto da população atualmente moradora e usuária do centro. No entanto, como explicitado nos documentos analisados, esse conjunto de ações seria fundamental para alcançar o objetivo de "reverter o processo de degradação e desvalorização" (PMSP/EMURB, 2004a). Ou seja, trata-se de um conjunto de intervenções urbanísticas, ações de controle e segurança, realizadas com aporte de recursos públicos, que criariam um ambiente urbano mais atrativo aos investimentos privados - elemento fundamental “da estratégia de mudar o perfil econômico e as funções do centro” (BID, 2004a, p.8).

Deve-se atentar para o fato de que, esse tipo de estratégia de "alavancagem" tende a resultar na redinamização da economia local e na valorização fundiária e imobiliária da área, acabando por expulsar os usos populares e moradores de baixa renda; resultados que foram comuns nas experiências estrangeiras que a aplicaram, como veremos no capítulo 3.

Um outro aspecto a ser destacado, que tem sido considerado fundamental para a construção do ambiente favorável aos negócios privados, é a questão da acessibilidade. Em alguns documentos e artigos produzidos no âmbito do programa, foi apontado que as ligações viárias norte-sul e leste-oeste facilitaram os fluxos de passagem, mas não o acesso ao centro propriamente, transformando-o em um nó de circulação; uma condição determinada pela estrutura rádioconcêntrica implantada desde os anos 40 com o Plano de Avenidas. Os calçadões implantados na década de 1970, como medida de melhoria do ambiente urbano - diminuição dos congestionamentos, da poluição ambiental etc. - passaram a ser associados à perda de acessibilidade local por automóvel, à falta de conexão entre setores do centro, ao êxodo de atividades econômicas para as "novas centralidades" a sudoeste da metrópole e à desvalorização imobiliária (SILVA, 2004, p.21-2).

Desta forma, preocupando-se com a questão da micro-acessibilidade por automóveis na Área de Interesse do programa, foi proposto o projeto Novo Calçadão, prevendo estudos para a delimitação de um leito para o tráfego de veículos particulares. Em associação com os projetos 
Corredor Cultural e Quadrilátero Piloto ${ }^{44}$, sua intenção era, a princípio, melhorar os calçadões para a circulação de pedestres, tratando o calçamento, os equipamentos e mobiliários urbanos, porém, permitindo o acesso de automóveis a edifícios e espaços públicos, como o Centro Cultural Banco do Brasil. Tal proposta não chegou a ser implantada na gestão Marta Suplicy (2001-2004), mas uma versão da mesma idéia de abrir os calçadões para automóveis está em execução pelo atual governo, com intervenções nas ruas 7 de Abril, 24 de Maio, Dom José de Barros e Florêncio de Abreu ${ }^{45}$.

Outras intervenções também foram propostas com o objetivo de aumentar a acessibilidade por automóvel à área central e ao centro principal. Os projetos pretendiam completar o sistema viário da contra-rótula ${ }^{46}$, até então inconcluso em sua parte norte, e executar ligações viárias de apoio em alguns dos principais acessos ao centro (Avenidas Presidente Wilson e do Estado, a sudeste, e entre as regiões do Pari e da Barra Funda, a norte), atentando para a "inexistência de conexões físicas mais adequadas" na ligação entre o centro e a zona leste (PMSP/SMT/SPTrans/CET, 2004, p.13). Previam também implementar melhorias viárias na área da Favela do Gato, alterando o geométrico da Marginal Tietê, e aplicar uma estratégia de operação, controle e monitoria do trânsito - gestão de controle de trânsito.

\subsubsection{Transporte Público}

As ações focadas no transporte público, ao contrário das intervenções urbanísticas e demais ações abordadas até aqui, aparentemente não tinham como estratégia a melhoria do ambiente urbano como forma de atrair o interesse de setores da iniciativa privada. Tais ações integravam o componente 4 (Transporte e Circulação), associadas à política da Secretaria Municipal de

\footnotetext{
${ }^{44}$ Como apontado anteriormente, o projeto do Quadrilátero Piloto foi proposto em 2001, como ação inicial do Plano Reconstruir o Centro para a área compreendida entre as ruas 7 de Abril, Conselheiro Crispiniano, avenidas São João e Ipiranga. Englobava intervenções de melhoria em calçadas, iluminação, reordenamento do mobiliário urbano, reforma de fachadas e controle de anúncios publicitários e do comércio ambulante. Segundo Luis Octávio da Silva, em entrevista cedida à autora em janeiro de 2008, esse projeto foi executado parcialmente, baseando-se na articulação com os setores da sociedade civil presentes na área, em especial com comerciantes.

$45 \mathrm{O}$ que tem sido feito em trechos destas ruas é o lançamento de asfalto diretamente sobre o piso pré-existente de mosaico português e granito, sem guias ou delimitação precisa de piso entre calçada e leito carroçável - há apenas demarcadores do tipo "poste" com altura de cerca de $1 \mathrm{~m}$. Em nossa freqüência à área, percebe-se a utilização do leito carroçável pelos transeuntes, mostrando que o espaço deixado para calçada não comporta o volume existente de pedestres, ao mesmo tempo em que o fluxo de automóveis é quase inexistente.

46 A rótula e a contra-rótula viária integram a estrutura rádioconcêntrica da cidade, são anéis de irradiação que fazem conexão com diversos corredores radiais de circulação. Ao mesmo tempo, a rótula central representa uma zona de transição entre a área pedestrianizada dos centros Velho e Novo e a área motorizada, de acesso das vias radiais. A rótula central é formada pelas seguintes vias: Av. Ipiranga, Av. S. Luis, Vd. Nove de Julho, Vd. Jacareí, R. Maria Paula, Vd. Da. Paulina, Pça. João Mendes, R. Anita Garibaldi, Av. Rangel Pestana, Vd. 25 de Março, R. da Figueira, Av. Mercúrio e Av. Sem. Queirós. E a contra-rótula: Av. Duque de Caxias, Rua Mauá, Av. do Estado, R. do Glicério, Vd. Leste-Oeste, Ligação Leste-Oeste, Vd. Jaceguai, Vd. Júlio de Mesquita Filho e R. Amaral Gurgel.
} 
Transportes para reestruturação da rede em toda a cidade - através do Sistema Interligado de Transporte, com a implantação do Passa Rápido (corredores de ônibus) e do Bilhete Único ${ }^{47}$. Ocorrendo de forma independente da montagem do programa para a área central, a política dessa Secretaria contava com recursos do Bando Nacional de Desenvolvimento Econômico e Social $(\mathrm{BNDES})^{48}$, sendo que as ações relativas à área central foi considerada, em grande parte, como contrapartida da Prefeitura dentro do financiamento do BID (tabela 1).

\section{Mapa 4: Propostas do componente “Transporte e Circulação” na Área de INTERESSE}

\section{Circulação e Acessibilidade ÁREAS DE INTERVENÇÃO}
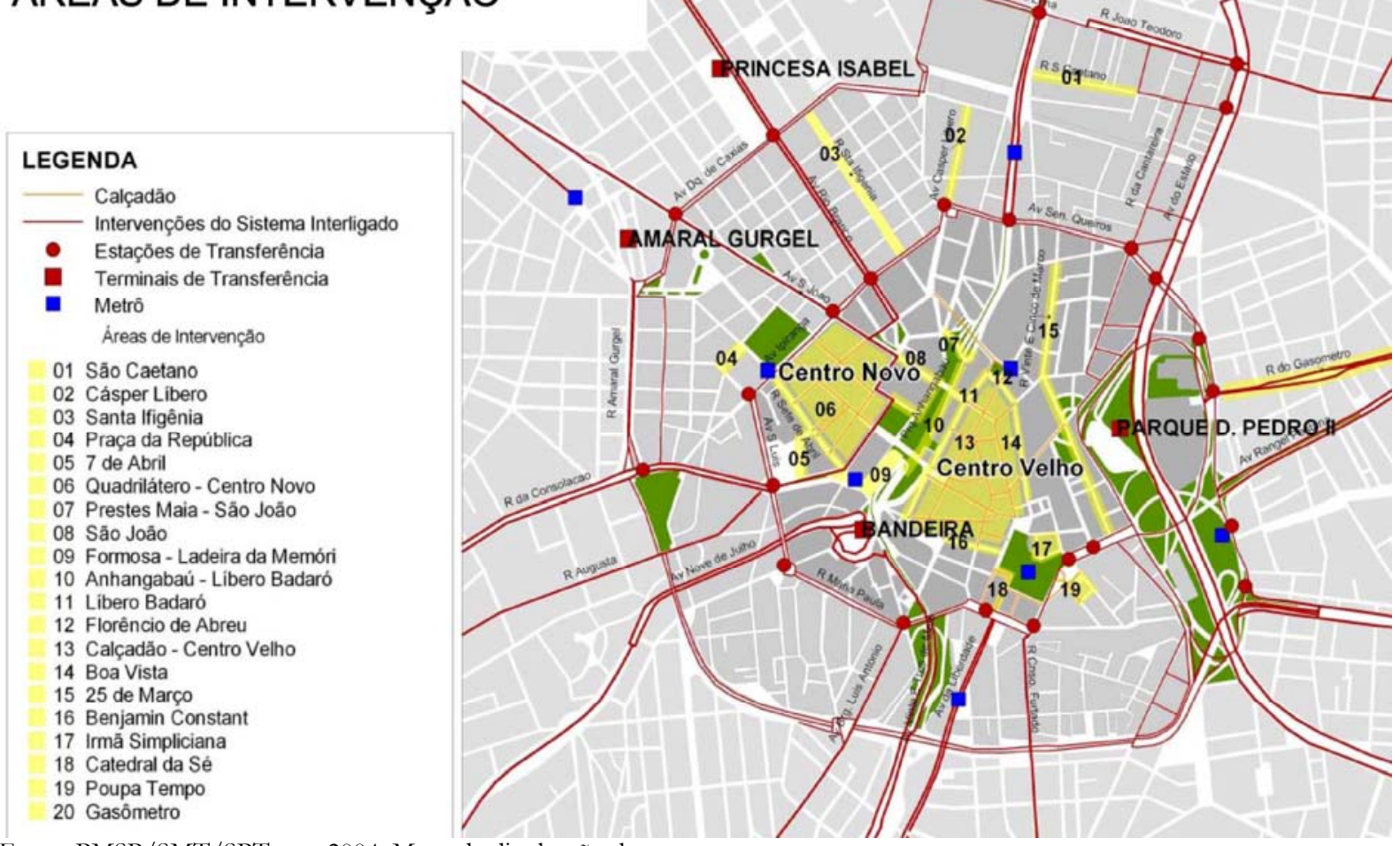

Fonte: PMSP/SMT/SPTrans, 2004. Mapa de divulgação das propostas.

Obs: Nota-se no mapa três tonalidades de cinza: a mais escura configura a área interna à rótula viária, onde se localizam os calçadões; a mediana mostra a coroa (ou ferradura), definida pela rótula e contra-rótula; e a mais clara é a área externa a contrarótula. A porção delimitada pela contra-rótula é a Área de Interesse do Programa Ação Centro.

Ainda assim, em nossa análise, percebemos que esse conjunto de ações também iria contribuir para a construção do citado “ambiente favorável” aos investimentos privados. Detalhando a política da Secretaria de Transportes no âmbito do programa, uma de suas principais estratégias

\footnotetext{
47 O Bilhete Único permite a realização de baldeações pelos usuários, mediante pagamente de apenas uma tarifa, por um período de duas horas.

48 Assim como o financiamento do BID para o centro, esse empréstimo foi outra operação de crédito autorizada pelo Senado em condição de excepcionalidade ao endividamento do município de São Paulo.
} 
seria minimizar a confluência das linhas de ônibus nos terminais centrais, remanejando $30 \%$ delas para estações de transferência a serem implantadas na rótula e contra-rótula, em conjunto com um Passa Rápido (mapa 4). Seu objetivo, reforçando a busca pela melhoria da qualidade ambiental da área, era diminuir as baldeações e o tráfego de passagem, estimado em 2 milhões de pessoas - fluxo esse que seria diminuído em cerca de 700 mil pessoas.

Como conseqüência dessas ações, esperava-se diminuir a concentração do comércio informal, uma vez que, em função do grande fluxo de pedestres - potenciais consumidores - seu ponto preferencial tende a ser os locais de passagem e próximos às estações e terminais. Desse modo, eram reforçadas as ações de controle e restrição à atividade informal apontadas anteriormente, já que a retirada de ambulantes das ruas seria mais um elemento do quadro de condições necessárias para atração de investimentos privados na área central. Esse entendimento é explicitado por um dos gestores do programa: "não se pode negar que o comércio informal constitui um dos principais desafios para reabilitação do centro da cidade, sendo que sua existência e dimensões constituem um dos problemas mais recorrentemente apontados como razão de deterioração do centro" (SILVA, 2004, p.20).

Apesar da importância estrutural das propostas relativas ao transporte, que buscavam articulação do centro com a rede viária e de transportes do município como um todo, o recorte feito pelo Ação Centro, a nosso ver, demonstrou a intenção de induzir a transformação de usos e população na área central. Buscava, ao mesmo tempo, diminuir a quantidade de ônibus que acessa o centro e facilitar a micro-acessibilidade por veículos particulares, o que, por sua vez, era condizente com os objetivos de atrair a instalação de novas empresas e novos moradores de renda média.

Mesmo que não tenha constado na lista de ações do programa (tabela 1), vale destacar as iniciativas realizadas pela EMURB frente à questão dos estacionamentos, uma vez que também fizeram parte das propostas de intervenção na área central. Seguindo a mesma lógica abordada anteriormente e explicitando uma priorização à acessibilidade por automóveis, em especial na Área de Interesse (distritos Sé e República), a EMURB contratou uma consultoria da TTC Engenharia de Tráfego e Transporte S/C (2004) para verificar a possibilidade de implantar garagens subterrâneas e indicar diretrizes para uma política de estacionamentos na área central. Tal consultoria identificou carência na oferta de vagas no Centro Principal (definido pela contrarótula viária) e uma "sobra" de vagas no Centro Intermediário e Periférico (definidos pela coroa entre a rótula e contra-rótula, e por uma "franja" externa a contra-rótula). Em setembro de 2003, as relações entre demanda e oferta de vagas nos Centros Principal, Intermediário e Periférico 
eram, respectivamente, $82 \%$ (23.182 para 18.953 vagas), $142 \%$ (22.358 para 31.814 ) e $128 \%$ (19.388 para 24.851).

Diante dos possíveis impactos do programa em sua Área de Interesse - crescente demanda por vagas em função da transferência dos órgãos públicos e do provável aumento da área construída para atividades do setor terciário ${ }^{49}$ - o estudo apontou a necessidade de aumentar o número de vagas de estacionamento, mesmo com a provável diminuição da demanda decorrente das melhorias no sistema de transporte público. Apesar do posicionamento da coordenadora do programa, citado abaixo, as propostas visavam aumentar a oferta de vagas na Área de Interesse, entre a rótula e a contra-rótula.

Nós temos uma proposta de circulação especial na área central, que articula ônibus mais leves circulando pela área e uma política de estacionamentos e garagens subterrâneas, porque não adianta nada tirar os ônibus e as pessoas passarem a vir de carro. Então, é necessário regulamentar o acesso de veículos a essa região. Nós já vivemos um período em que o Centro era muito congestionado em função dos automóveis. Atualmente ele está menos congestionado e as pessoas passaram a utilizar mais o transporte coletivo. Portanto também não é o caso de enchê-lo novamente com garagens, incentivando o transporte individual, como pretendem alguns empresários, porque assim teremos de volta o congestionamento, o que não é um elemento positivo para o desenvolvimento dessa área. (SOMEKH, 2004a, p.85)

Este tema tem sido bastante polêmico entre os diferentes grupos que atuam no centro - poder público, empresariado, setores do mercado imobiliário, pesquisadores etc. - como mostram as recentes discussões a cerca da abertura de calçadões, com destaque aos debates promovidos pela Viva o Centro em 2005. Por um lado, a elevada circulação de veículos ocasiona grandes congestionamentos e piora a qualidade ambiental do centro, o que leva à defesa pela aplicação de medidas restritivas ao acesso do automóvel. Por outro, a dificuldade "de estacionamento e de acesso à porta ou ao interior dos edifícios tem sido levantada como um elemento dificultador para a instalação de atividades econômicas e de empreendimentos residenciais voltados às faixas de renda média na área central” (LABHAB/LILP/CAIXA, 2006, p.194).

Talvez por esse caráter polêmico, uma proposta concreta para estacionamentos não tenha constado na listagem de ações do Programa Ação Centro ${ }^{50}$. Ainda assim, o item 2.4 do Anexo II de seu Regulamento Operacional, específico sobre o componente de Transporte e Circulação, aponta que as ações de circulação e acessibilidade deveriam contar com "O desenvolvimento de

\footnotetext{
49 Esses impactos foram analisados em dois estudos, um primeiro elaborado por consultor internacional indicado pelo BID Remy Prud'Homme (2002) - e um segundo contratado pela EMURB e realizado pelo Laboratório de Urbanismo da Metrópole (LUME), com coordenação do economista Ciro Biderman (PMSP/EMURB; LUME, 2003).

50 Diferente das propostas anteriores, em que as garagens eram marcantes, principalmente na carta-consulta de 1997 (POLIS/CARE, 2007).
} 
estudos para a implantação de Estacionamentos e Garagens na área central" (PMSP/EMURB 2004d).

\subsubsection{Articulação com a Sociedade Civil e InCEntivos À Iniciativa Privada}

Conforme exposto até aqui, um dos principais objetivos do programa seria viabilizar a instalação de atividades econômicas compatíveis com o centro reabilitado - inclusive do "setor terciário de alta tecnologia" (SOMEKH, 2004b, p.4) - a atração de investimentos privados e de usuários de maior poder aquisitivo. Nesse sentido, as intervenções de melhoria da infra-estrutura, de edifícios e espaços públicos foram apresentadas como uma estratégia de tornar o centro um lugar mais convidativo a esses investimentos, (re)inserindo-o na dinâmica do mercado imobiliário privado.

Em conjunto com essas intervenções e buscando facilitar a articulação com setores da iniciativa privada, foram criados mecanismos de gestão e instrumentos urbanísticos. Entre eles, a Lei de Incentivos Seletivos (Lei Municipal 13.493/03 e Decreto Municipal 44.493/04), com o objetivo de estimular o investimento da iniciativa privada, mediante concessão de benefícios fiscais e tributários (isenções de IPTU, ITBI-IV e ISS) para determinados usos e tipos de projetos compatíveis com o objetivo de desenvolvimento da área central. Incidindo na Área de Interesse do programa (distritos Sé e República), buscava incentivar a realização de empreendimentos imobiliários privados, residenciais ou não, e a conservação de bens imóveis de valor histórico, sendo que o benefício seria concedido mediante implantação do projeto pelo interessado. Essa lei não chegou a ser aplicada e foi substituída por outra, que reforça os objetivos do projeto "Nova Luz" da atual gestão (LM 14.096/06 e DM 46.996/06) ${ }^{51}$.

O elemento fundamental para viabilizar e potencializar a atração de capital privado para a área, seria a instalação da Agência de Desenvolvimento do Centro vinculada à Diretoria da EMURB, o que estava previsto dentro do componente "Transformação do Perfil Econômico e Social” do programa. Segundo o decreto que a regulamentou (DM 44.089/03), seu objetivo era "prestar apoio aos setores público e privado e à sociedade civil em projetos, programas e ações que propiciem o desenvolvimento econômico e social sustentável do Centro" (art. 11). Dessa forma, teria um papel de articular os diversos setores econômicos privados envolvidos ou interessados

\footnotetext{
51 Essa nova lei, com área de abrangência similar a do projeto "Nova Luz", busca estimular a instalação de atividades econômicas mais sofisticadas do que as existentes (galeria de artes, shopping centers, escritórios de propaganda e marketing, empresas de informática e tecnologia, entre outras) com o objetivo de "promover e fomentar o desenvolvimento adequado da região" (Art. $\left.1^{\circ}\right)$. Nesse sentido, o atual "Programa de Incentivos Seletivos tem em vista atrair novos usos e freqüentadores para 'melhorar' os padrões de uma área atualmente ocupada por grande quantidade de cortiços e atividades econômicas populares" (LABHAB/LILP/CAIXA, 2006, p.96).
} 
na recuperação do centro, como um "agente facilitador e de fomento", a fim de canalizar vontades e captar recursos necessários à potencialização das atividades econômicas existentes e de novas que venham a dinamizar a economia local (SILVA, 2004, p.30). Como apontado no documento Informe de Proyecto, a criação da Agência seria "parte fundamental da estratégia para a transformação econômica do centro da cidade de São Paulo e, consequentemente, para sua reabilitação" (BID, 2004a, p.7).

De acordo com o que tem sido realizado em cidades de países centrais do capitalismo, a Agência do Centro poderia ser entendida como um instrumento de gestão de caráter neoliberal, através do qual se estabelecem parcerias público-privadas, flexibilizando os procedimentos administrativos e burocráticos das ações sobre o território - uma instância mais flexível e eficiente do que os tradicionais órgãos públicos. Sua atuação comporia o "ambiente favorável” a que nos referimos anteriormente, em conjunto com os investimentos públicos canalizados em intervenções urbanísticas e melhoria do ambiente urbano: projetos motores, requalificação de espaços públicos, recuperação do patrimônio histórico, melhoria da limpeza e manutenção, restrições aos ambulantes, aumento da segurança e da acessibilidade por automóveis, entre outros. Como será tratado no capítulo 3, as técnicas do planejamento estratégico - também difundidas pelos bancos multilaterais como o BID - num contexto da propagada diminuição do Estado, pressupõem que a instalação dessas agências, corporações ou empresas de capital misto é um meio eficaz para a recuperação de áreas urbanas consideradas degradadas, na medida em que potencializa sua retomada econômica e valorização imobiliária, a partir de recursos privados ${ }^{52}$.

A experiência realizada na região do ABC paulista foi importante referência para constituição da Agência do Centro de São Paulo. A urbanista Nádia Somekh, antes de assumir a coordenação do Programa Ação Centro, participou da montagem e gestão da Agência de Desenvolvimento do $\mathrm{ABC}$, criada no âmbito do projeto Eixo Tamanduateí em Santo André, trazendo a referência para São Paulo. Essa experiência também se pautou na atração de capital privado para a recuperação de uma antiga área industrial ao longo do eixo da ferrovia Santos-Jundiaí, seguindo os moldes do planejamento estratégico.

O que se percebe, o que está sendo trazido para o Centro, e que não deve ficar restrito a ele, é uma nova mentalidade de gestor público. Uma mentalidade que não é do burocrata, mas é daquele que resolve problema, que trabalha matricialmente, que articula setores e não tem preconceito de atrair novos investimentos, sempre, é claro, com o pressuposto da inclusão social, da redução das desigualdades. Um perfil de gestor que tem a ver com a

\footnotetext{
52 É conhecida a crítica às intervenções pautadas nas parcerias público-privadas, desmontando o mito de que elas se justificariam pela "economia" dos gastos públicos, uma vez que, como mostrado por diversos autores (FIX, 2000; FERREIRA, 2007), esses processos exigem consideráveis recursos públicos na melhoria da infra-estrutura, do ambiente urbano em geral, para que os investimentos privados realmente ocorram.
} 
atração de novos investimentos e, mais do que isso, visa à construção de um tecido produtivo-social e a busca de novas alternativas de trabalho e renda. Essa é a nossa perspectiva: captar recursos, trazer investimentos e, ao mesmo tempo, construir um tecido social mais refinado, vinculado a um desenvolvimento local. (SOMEKH, 2004a, p.82)

Ao mesmo tempo, o programa também contava com uma instância de gestão aberta à participação dos interessados na recuperação do centro. Denominada Fórum de Desenvolvimento Social e Econômico do Centro, essa instância foi montada a partir da extinção da Comissão PROCENTRO de 2001, sendo "um canal de participação dos cidadãos na proposição de diretrizes e prioridades de desenvolvimento econômico e social sustentável do Centro de São Paulo" (DM 44.089/03). Vinculada à estrutura administrativa da EMURB, suas funções e atribuições seriam as mesmas da antiga Comissão PROCENTRO (SILVA, 2004), porém sem caráter deliberativo, ainda que sua composição tenha sido ampliada, incluindo representantes de outros conselhos e comissões existentes (habitação, orçamento participativo, política urbana) e abrindo a participação a qualquer organismo governamental e grupo organizado da sociedade civil que tivesse interesse.

O Fórum se realizava através de 4 Grupos de Trabalho Temáticos (GTs), que chegaram a se reunir semestralmente, em maio e outubro de 2004: GT Desenvolvimento Social, GT Desenvolvimento Habitacional, GT Desenvolvimento Econômico e GT Desenvolvimento Urbano/Ambiental. Nas primeiras reuniões de cada GT os participantes levantaram as principais problemáticas do centro, a partir das quais se definiram outros subgrupos, com temas específicos a discutir, reunindo-se com maior regularidade. A idéia era que os temas específicos fossem debatidos nos subgrupos e depois levados para encaminhamento nas reuniões dos GTs do Fórum e para a Coordenação Executiva Ação Centro. Também era intenção integrar suas discussões com os outros canais representativos existentes, em especial com o Orçamento Participativo da Subprefeitura Sé e o com Conselho de Representantes das Subprefeituras (PMSP/EMURB, 2004a).

Foram abordados os temas da recuperação (retrofit) de edifícios, dos cortiços, dos condomínios, das tarifas sociais (luz e água), dos planos diretores regionais, entre outros, sendo que ao longo de 2004, o trabalho dos grupos priorizou seminários de formação dos próprios participantes. No entanto, os encaminhamentos não chegaram a ser feitos e as discussões dos GTs não foram incorporadas ao trabalho do Ação Centro, já que, com o fim do governo, esses grupos se desmobilizaram ${ }^{53}$. 53 Informações obtidas a partir de entrevistas cedidas em novembro de 2007 e janeiro de 2008 pela arquiteta Renata Milanesi,
gestora responsável pela coordenação dessas instâncias de gestão até o final de 2004. Vale destacar que a constituição do Fórum 
Além das instâncias de participação e de articulação com a iniciativa privada, o programa contava com uma Coordenação Executiva dentro da EMURB. Seu caráter operativo se mantinha como na Coordenação Executiva do antigo PROCENTRO, com o papel de "coordenar e assegurar que as diretrizes propostas pelo Fórum fossem incorporadas ao planejamento e gestão dos programas e instrumentos de reabilitação e desenvolvimento do Centro" (DM 44.089/03). A coordenação era responsável pela operacionalização da Lei de Fachadas, pela elaboração de pareceres sobre projetos, bem como análise e elaboração de legislações urbanísticas para o centro. Ela também deveria monitorar as atividades da Agência de Desenvolvimento.

De composição paritária, teria 6 representantes do poder público e 6 da sociedade civil, mas como determinado em decreto, funcionou ao longo de 2004 com uma Coordenação Provisória, a qual contava com: o Presidente da EMURB, o Subprefeito da Sé, 4 representantes dos órgãos ou empresas públicas envolvidos mais diretamente nos programas; e com 2 representantes de cada uma das entidades listadas - Associação Viva o Centro, Fórum Centro Vivo, União dos Movimentos de Moradia, União de Mulheres, Sindicato das Empresas de Publicidade, Consórcio São Paulo Minha Cidade ${ }^{54}$.

Outra ação do programa com intuito de atrair o capital privado para o centro foi a elaboração de legislação urbanística condizente ao desenvolvimento urbano almejado. Além da revisão da Operação Urbana Centro e da Lei de Fachadas, os Planos Regionais Estratégicos das Subprefeituras Sé e Mooca, elaborados com recursos do BID - componente "Reversão da Desvalorização Imobiliária e Recuperação da Função Residencial” - foram apresentados como mecanismos que garantiriam o retorno dos investimentos privados ao centro.

A elaboração de propostas de legislação urbanística e tributária (...) prevê a implantação dos Planos Diretores das Subprefeituras da Sé e da Mooca, que fornecerão o marco regulador estável de que os investidores imobiliários precisam para voltar a apostar em empreendimentos de usos residencial e não-residencial - principalmente, para o setor terciário, com instalações de última geração - na região. (SOMEKH, 2004b, p.2. grifos nossos)

Como apontado em texto assinado por técnicos do BID (Informe de Proyecto), "um componente chave para o êxito do programa é a mudança da legislação urbanística do centro da cidade,

ocorreu apenas depois da aprovação do programa pelo BID no final de 2003, quando as ações já estavam definidas, pelo menos em linhas gerais. Apesar de terem sido realizadas "pesquisas qualitativas" com a população, para definir o que era o centro e quais suas principais problemáticas, não se pode afirmar que houve uma discussão prévia ou tomada de decisão conjunta para a montagem do programa.

54 Com a mudança de governo em 2005, a Agência, o Fórum e a Coordenação Executiva provisória tiveram suas atividades interrompidas e o Programa de Reabilitação da Área de Central da Cidade de São Paulo voltou a ser chamado PROCENTRO. Em abril de 2005 foi criada, no âmbito da Subprefeitura Sé, a Comissão Executiva Especial Ação Centro, com a atribuição única de operacionalizar a Lei de Fachadas (DM 45.832/2005), tendo sido extinta pelo decreto de criação do Comitê Gestor do PROCENTRO e sua Secretaria Executiva (DM 46.303/2005 e DM 46.780/2005). Esse último revogou o decreto 44.090/2003, mas manteve a EMURB como órgão executor. 
mediante o financiamento da elaboração dos planos diretores das subprefeituras Sé e Mooca". (BID, 2004a, p.34). A Lei de Incentivos Seletivos também foi apontada nesse documento como "parte do pacote de suporte básico para alcançar os objetivos do programa" (op.cit., loc.cit).

Nessa mesma lógica - e por exigência do banco financiador, como veremos no capítulo 3 também era objetivo atrair moradores de renda média, de maior poder aquisitivo, como estratégia para a reversão da desvalorização imobiliária e do esvaziamento residencial, sendo vital para a transformação de usos e atividades almejada. Passando a integrar o Morar no Centro quando este foi inserido no escopo do financiamento do BID, as propostas de atração de renda média alinhava-se com os objetivos do Ação Centro em repovoar a área central com diversidade e equilíbrio de classes sociais. Segundo material de divulgação do programa, estimular novos lançamentos imobiliários para a classe média seria uma forma de "buscar a diversidade habitacional no território" (PMSP/EMURB, 2004a). Percebe-se aqui a associação entre a recuperação do centro com a idéia de "diversidade social" abordada anteriormente, a qual tem servido ao ocultamento dos objetivos de "gentrificação" presentes em muitas experiências estrangeiras de revitalização de áreas urbanas consideradas degradadas (BIDOUZACHARIASEN, 2006; SMITH, 2006).

Compondo o conjunto de programas habitacionais, foram propostos mecanismos para que famílias de renda média viessem morar no centro, baseando-se nos diagnósticos de subutilização dos imóveis e de perda de população indicada pelos dados do IBGE de 1980 e 1991. Junto com "campanhas de informação e difusão sobre as vantagens de viver no centro" (SOMEKH, 2004b, p.3), estavam previstos um Programa de Recuperação de Edifícios, destinado à melhoria de condomínios deteriorados ou em risco e a entrega de prêmios em dinheiro para reforma de áreas condominiais e de apartamentos em edifícios com bom estado de conservação. O enfoque era dado a edifícios e unidades habitacionais localizados nos distritos Sé e República e nos Perímetros de Reabilitação Integrada do Habitat (PRIH) Luz, Brás e Glicério, os quais serão abordados mais adiante. Segundo o Anexo I do Regulamento Operacional, o montante total de recursos destinados para edifícios seria de $\mathrm{R} \$ 4,2$ milhões e para unidades foi estabelecido que cerca de 300 interessados - pioneiros - poderiam pleitear o prêmio, não ultrapassando R $\$ 10$ mil ou 20\% do valor de negociação do imóvel (PMSP/EMURB, 2004d).

Através do programa, também se buscava realizar articulações com setores do mercado imobiliário privado, a fim de viabilizar a produção de unidades para renda média, através de construções novas ou de reformas de edifícios existentes. Cogitava-se fornecer apoio tecnológico a empresas para reforma e modernização de edifícios (SOMEKH, 2004b, p.3). No entanto, não 
há informações sobre a aplicação desses programas, nem sobre lançamentos imobiliários ocorridos no período da gestão 2001-2004.

Importante destacar que o interesse do mercado imobiliário residencial em investir no centro tem se perdido nas últimas décadas, o que se percebe pela diminuta quantidade de lançamentos na região ${ }^{55}$ com relação ao total do município, nos períodos de 1985-2000 (7,4\%) e 1999-2004 (9,7\%), segundo dados da EMBRAESP - Empresa Brasileira de Estudos de Patrimônio (LABHAB/LILP/CAIXA, 2006). Isso se deve às vantagens lucrativas oferecidas em outras regiões da cidade - em especial os bairros a sudoeste - e a uma tradição do próprio mercado em empreender construções novas em detrimento de reformas e reciclagens, o que se torna extremamente complexo em áreas urbanas consolidadas, e com concentração de imóveis tombados pelo patrimônio histórico, como o centro da cidade ${ }^{56}$. Como afirma Cláudio Bernardes - atual presidente da EMBRAESP - sobre a realização de dois empreendimentos para renda média, entre 1999 e 2000: “foi um processo novo, pois estávamos acostumados a construir coisas novas" (BERNARDES, 2001, p.92).

Em sua pesquisa sobre a habitação no centro, Tsukumo (2007, p.184) destaca que os atuais padrões de empreendimento localizados em bairros centrais utilizam "grandes glebas, construção de várias torres, tipologia com programa extenso, áreas dos cômodos pequenas, grandes áreas de lazer comum nos térreos, no mínimo duas vagas para automóveis, e rígidos sistemas de fechamento e segurança". O isolamento total dos edifícios em relação ao entorno seria a única forma viável de realizar empreendimentos nesses bairros, permitindo a "diluição das características negativas da área", que "sofre preconceito do consumidor principalmente por causa da questão da segurança e da prostituição" (CURIATTI, 2006, apud TSUKUMO 2007, p.185) $)^{58}$.

Percebe-se que a implantação das estratégias de atração de moradores de maior poder aquisitivo exigiria a realização do conjunto de melhorias do ambiente urbano - a construção do "ambiente favorável" a que nos referimos no item anterior - para adequar o centro aos padrões das camadas

\footnotetext{
5513 distritos centrais: Barra Funda, Bela Vista, Belém, Bom Retiro, Brás, Cambuci, Consolação, Liberdade, Mooca, Pari, República, Santa Cecília e Sé. Partindo de outra divisão territorial (zonas Origem/Destino do metrô), Silva (1999) realizou análise comparativa entre a área central e a região da Avenida Paulista, Jardins e Pinheiros, quanto à concentração de lançamentos residenciais no período 1988-1997 (0,9\% e 5,1\%, respectivamente, com relação ao total do município).

56 Desde 1992 as imediações do Vale do Anhangabaú (Resolução. 37/Conpresp/92) e uma grande área do chamado Centro Novo, principalmente a área abrangida pelos calçadões, estão protegidas pelo instituto do tombamento, por resolução do Conpresp - Conselho Municipal de Preservação do Patrimônio Histórico, Cultural e Ambiental da Cidade de São Paulo. Em julho de 2007 foi aprovada outra Resolução do Conpresp tombando a área do Centro Velho, a qual envolve as proximidades da Praça da Sé, a região da Rua 25 de Março e do Mercado Municipal (Res. 17/Conpresp/07).

57 Um desses empreendimentos, localizado na Rua 7 de Abril (Edifício Samambaia), próximo à esquina com a Avenida Ipiranga, adaptou um antigo hotel para unidades de kitchnets (studios) e de até 1 dormitório.

58 Arnaldo Curiatti é sócio-proprietário e diretor da Abyara Consultoria Imobiliária.
} 
de renda média, gerando a incorporação de empreendimentos privados destinados a elas. Esse processo, por sua vez, acarretaria valorização imobiliária, podendo dificultar ou mesmo impedir a realização dos programas de habitação social, os quais serão abordados mais adiante.

\subsubsection{ATENÇÃo AOS GRUPOS VULNERÁVEIS}

Ao mesmo tempo em que o Programa Ação Centro foi formatado com o objetivo de promover o desenvolvimento econômico e social da área central, por meio da atração de capital privado e da transformação dos padrões de uso e ocupação do solo, apontou a necessidade de atentar para os possíveis efeitos "negativos" dessa estratégia de recuperação do centro. Se concretizadas, essas ações poderiam gerar um processo de expulsão dos moradores e freqüentadores de baixa renda, bem como dos usos populares, inviabilizando aquilo que o programa também apresentou como sendo seu objetivo: a "inclusão social”.

Nesse sentido, os documentos oficiais apresentaram como fundamental a implantação de programas sociais que buscassem minimizar esses efeitos decorrentes das transformações na dinâmica econômica e social da área central. Segundo documento elaborado pela Secretaria Municipal de Assistência Social (SAS), "reabilitar o centro de São Paulo não é selecionar quem vive ou trabalha nesta região, não é expulsar de lá a população de rua e 'empurrar o problema' para outras áreas" (PMSP/SAS, 2004, p.20).

Afastando-se das estratégias de atração de investimentos privados, foram englobadas as ações de atenção aos grupos vulneráveis em andamento em SAS, integrando-as no componente “Transformação do Perfil Econômico e Social” e organizando 7 vetores de atuação (tabela 1). Entendendo por grupos vulneráveis ${ }^{59}$ a parcela da população em risco frente aos possíveis resultados da implantação do programa, o público alvo das ações de assistência social era composto por pessoas em situação de rua, desde crianças e adolescentes inseridos no trabalho infantil, até adultos e idosos; famílias encortiçadas; catadores de materiais recicláveis; entre outros. Entre as principais ações se destaca o Projeto.Oficina.Boracea, que envolveu a reforma de um equipamento público existente (Clube Municipal Raul Tabajara, no distrito da Santa Cecília) para receber diversas ações da secretaria: acolhida (albergue), recuperação da convivência, construção

\footnotetext{
$59 \mathrm{O}$ conceito de vulnerabilidade social que embasou a montagem dessas ações foi apresentado pelos documentos da Secretaria Municipal de Assistência Social da seguinte forma: "A noção de risco social e de vulnerabilidade se baseia em um conjunto de situações de fragilidades, incertezas, destituições que terminam por precarizar a vida humana a tal ponto que provocam a perda de vínculos sociais e de liames com a vida coletiva. Tornam-se seres abandonados que perambulam sem qualquer condição ou força individual para enfrentar o hoje, ou o amanhã. É o limiar da sobrevivência que se instala onde os padrões de dignidade humana se esgarçam e destituem condições básicas de privacidade e subsistência e existência.” (PMSP/SAS, 2004, p.2).
} 
de laços afetivos e capacitação profissional, atendendo cerca de 640 moradores de rua/catadores de materiais recicláveis. Tal projeto foi realizado como um modelo a ser estendido a outras partes da cidade, introduzindo uma abordagem integrada das ações de proteção e assistência social, baseada no levantamento das necessidades do público alvo.

Outras ações que estavam em andamento em SAS envolveram a realização de um Censo de Moradores de Rua ${ }^{60}$; capacitação do quadro de funcionários da secretaria; ampliação e melhoria da Rede de Proteção Social, implantando mecanismos para uma "saída" sustentável da rua; ações educativas e atividades em praças que, em conjunto com a atuação das bases comunitárias da GCM, visavam facilitar a abordagem e o encaminhamento da população atendida e, por fim, um espaço expositivo e de atividades artísticas desenvolvidas por entidades ligadas às ações de “inclusão social” - a Loja Social: Movimento Periferia no Centro.

Assim como o Projeto.Oficina.Boracea - que foi desmontado com a mudança de governo em 2005 - o conjunto de ações de assistência social foram pensadas visando sua ampliação para toda a cidade. Com um orçamento anual tradicionalmente baixo, a Secretaria de Assistência Social vislumbrou no financiamento do BID a possibilidade de potencializar suas ações, tomando o Ação Centro como apoio e garantia de recursos. Cabe destacar que os programas e ações de SAS ganharam considerável importância no total de recursos, abarcando um montante de U\$ 12,9 milhões (7,74\% do total), sendo U\$ 7,38 milhões financiados pelo BID e U\$ 5,5 milhões de contrapartida da Prefeitura (tabela 1).

Também foram englobadas ações de formação de funcionários públicos e de organizações não governamentais (ONGs) que prestavam serviços na área social, através de um programa de capacitação em Gerência Social com apoio do Instituto de Desenvolvimento Social do Banco Interamericano de Desenvolvimento (INDES/BID) e da criação de um Espaço Público de Aprender Social (ESPASO), localizado na Vila Mariana. Essas ações fizeram parte do componente "Fortalecimento Institucional do Município" (tabela 1, subcomponente 1.5.3).

Pode-se afirmar que esse conjunto de ações era um importante elemento de "inclusão social" do Programa Ação Centro, garantindo o atendimento à população vulnerável de forma integrada, em equipamentos localizados na própria área central. O mesmo ocorria com as iniciativas de reorientação do comércio informal propostas pela Secretaria do Desenvolvimento, Trabalho e

\footnotetext{
${ }^{60}$ Essa pesquisa identificou a maior concentração de moradores de rua nos distritos Sé, República e Santa Cecília, sendo que os dois primeiros apresentaram 30\% do total da cidade, o equivalente a 10 mil pessoas. Dados segundo Recenseamento da População de Rua, realizado em outubro de 2003 pela FIPE - Fundação Instituto de Pesquisas Econômicas, para a Secretaria Municipal de Assistência Social.
} 
Solidariedade (SDTS), que podem ser consideradas como alternativas para geração de emprego e renda, dando apoio e garantindo a "inclusão social".

Entre elas destacaram-se as ações de "Regulamentação, Requalificação e Reorientação do Comércio e dos Comerciantes de Rua no Centro da Cidade", que visavam à identificação e ordenamento dos espaços adequados ao exercício da atividade ambulante, incluindo recadastramento e emissão de Termos de Permissão de Uso (TPU); e o programa Oportunidade Solidária, que envolvia assessorias para formação de pequenos e micro-negócios ou de cooperativas, associações e outras formas de organização coletiva (redes de comércio solidário, clubes de troca, empresas em autogestão) (PMSP/EMURB, Anexo III, 2004d, p.3). Ainda foram englobadas no escopo da reabilitação da área central as propostas de concessão de micro-créditos para implantação de "quiosques" ou compra de imóveis, buscando transformar a atividade comercial dos ambulantes; de formação para auto-gestão de negócios; de bolsas de capacitação profissional; de implantação de centros populares de compras - os "Pop Centros"; e de encaminhamento para vagas de trabalho. Eram os programas Operação Trabalho, Capacitação Ocupacional e São Paulo Inclui.

No entanto, a organização desse conjunto de iniciativas apresentada no Regulamento Operacional do Programa Ação Centro - Anexo III (PMSP/EMURB, 2004d) reforçou, a nosso ver, o teor restritivo e inibidor da atividade ambulante que apontamos anteriormente, contribuindo com a criação do "ambiente favorável” para a atração dos investimentos privados. Integrando o subcomponente "Regularização do Comércio Informal e Atenção aos Grupos Vulneráveis", as ações de atenção aos grupos vulneráveis estavam diretamente ligadas ao aumento da segurança na área central, o que se tornava explícito na estruturação do subcomponente em "3 ações interdependentes": programas de assistência social, regulamentação do comércio de rua e o Programa Centro Seguro, da Secretaria Municipal de Segurança Urbana. As ações da Secretaria de Segurança apoiavam, portanto, os programas de SAS e SDTS, envolvendo a "presença social nas ruas" no primeiro caso e o policiamento no segundo, ambos respaldados na instalação de bases comunitárias e no aumento do efetivo da CGM. O Programa Centro Seguro, por exemplo, visava a "intensificação da segurança e repressão às atividades ilícitas" (PMSP/EMURB, Anexo III, 2004d).

Diante de sua estreita relação com a questão da segurança pública - ação da GCM - entendemos que as ações de assistência social e regulação do comércio informal, reforçariam a estratégia de atrair investimentos privados para o centro. Isso se daria mediante a retirada da população de rua e dos camelôs dos espaços públicos, atendendo-os na rede de proteção social e nos programas de 
reinserção, capacitação profissional, e geração de emprego e renda, bem como através de ações inibidoras e repressivas. Criava-se, portanto, uma ambigüidade nas propostas de reabilitação do Ação Centro, já que objetivos e estratégias díspares foram enquadrados num mesmo discurso: recuperar a área central da cidade, promovendo seu desenvolvimento econômico e social com diversidade. Tal discurso serviu tanto às intenções de atentar para população moradora e usuária da área central, inclusive aquela de baixa renda, como ao objetivo de gerar uma transformação em seus padrões sociais e econômicos, entendendo a melhoria do ambiente urbano como fator determinante para que setores da iniciativa privada voltem a investir no centro.

\subsubsection{Programas de HabitaÇão Social: MANTER A POPUlaÇão de baiXa RENDA}

Na mesma linha das ações de atenção aos grupos vulneráveis, foram inseridos no escopo do financiamento do BID os programas de habitação social, que também buscavam minimizar os efeitos "negativos" da possível valorização imobiliária decorrente das principais estratégias de intervenção na área central: atrair investimentos privados e gerar mudanças nos padrões de uso e ocupação do solo. Tais programas compuseram o Morar no Centro (ver tabela 1) e estavam em andamento na Secretaria Municipal de Habitação (SEHAB). Eles tiveram o papel de reforçar, em conjunto com a atuação dos movimentos de moradia, de assessorias técnicas e pesquisadores da universidade, a discussão da habitação social no contexto da reabilitação da área central, a qual havia sido iniciada ainda na década de 1990 durante a gestão Luiza Erundina (1989-1992).

Após o resultado das eleições municipais que deu a vitória a Prefeita Marta Suplicy (2001-2004), esses grupos se articularam em torno da formulação de um programa habitacional específico para o centro, então chamado "Morar Perto", enfocando bairros de urbanização consolidada. Com o início da gestão em 2001, o nome do programa foi alterado para Morar no Centro, abrangendo 13 distritos centrais: Sé, República, Bom Retiro, Santa Cecília, Consolação, Bela Vista, Cambuci e Liberdade (Subprefeitura Sé); Brás, Pari, Mooca e Belém (Subprefeitura Mooca); e Barra Funda (Subprefeitura Lapa). Esse processo de montagem foi permeado por referências internacionais de estruturação de políticas de habitação, especialmente os casos francês e italiano, desdobrando-se em convênios de cooperação internacional que permitiram a vinda de consultores, intercâmbios e estágios para técnicos da SEHAB.

Em paralelo as discussões sobre a reabilitação urbana da área central, que ocorriam no âmbito da montagem do Reconstruir o Centro e, depois, do Ação Centro, o tema do direito à moradia no centro e as primeiras realizações dos programas habitacionais embasaram a formulação de instrumentos urbanísticos que buscavam estimular e facilitar a construção de habitação por 
agentes públicos e privados. Como trataremos no capítulo 3, tal estímulo se daria através, principalmente, do cumprimento da função social da propriedade e da ZEIS 3, flexibilizando a legislação urbanística e edilícia, com parâmetros especiais que envolviam a utilização de coeficientes de aproveitamento maiores, exceção aos recuos exigidos, isenções de contrapartida financeira, entre outros. A expectativa era de que as ZEIS funcionassem não apenas como facilitadoras, mas também como mecanismo de controle dos valores fundiários, contribuindo para a realização das políticas habitacionais no centro. Nesse sentido, as legislações aprovadas no período - Plano Diretor Estratégico, Planos Regionais e Decreto de ZEIS/HIS - e que instituíram ou regulamentaram esses mecanismos, foram tidas como importantes marcos normativos para viabilizar a produção de Habitação de Interesse Social (HIS) e Habitação de Mercado Popular (HMP) no centro.

De certa forma, ao englobar esses programas em seu escopo, o Ação Centro também adotou um discurso de defesa pela moradia popular na área central, reforçando-o como uma das bandeiras da gestão Marta. Em conjunto com as ações de atenção aos grupos vulneráveis e de geração de emprego e renda, explicitava-se o objetivo de realizar a "reabilitação da área central com inclusão social". No entanto, ainda que os esforços dos técnicos da secretaria de habitação estivessem voltados para a constituição de uma política habitacional efetiva, no ensejo da regulamentação dos novos instrumentos urbanísticos, a inserção do Morar no Centro no contexto da reabilitação conferiu-lhe um caráter mais reativo - frente aos possíveis efeitos "negativos" mencionados anteriormente - do que propositivo.

A forma como se deu essa inserção colocou objetivos antagônicos num mesmo programa, num mesmo escopo de financiamento externo, construindo um discurso que serviu a todos esses objetivos. Para fazer caber propósitos contrários, portanto, o Programa Ação Centro dotou-se de um caráter ambíguo.

No documento de divulgação dos programas habitacionais destacou-se que as experiências internacionais de recuperação de áreas urbanas centrais já mostraram que um de seus principais efeitos é a expulsão da população de menor poder aquisitivo, exatamente porque provocam a valorização imobiliária (PMSP/SEHAB, 2004, p.9). Preocupando-se com uma eminente "gentrificação", as ações do campo habitacional buscaram "(i) melhorar as condições de vida dos moradores do Centro; (ii) viabilizar moradia adequada para pessoas que moram ou trabalham; e (iii) evitar o processo de expulsão da população mais pobre, que muitas vezes ocorre em políticas de reabilitação de centros urbanos" (op.cit, loc.cit.). 
Esses objetivos também tiveram como base um diagnóstico que ressaltou os seguintes fenômenos: perda de população moradora - em especial de famílias de rendas média e alta; altas taxas de subutilização dos imóveis existentes; aumento da concentração de cortiços e presença de muitas famílias com renda até 5 salários mínimos ${ }^{61}$. Diante disso, o programa contava com um conjunto de diretrizes e estratégias: priorizar a reforma de prédios vazios; instituir programas altamente subsidiados; criar mecanismos que incentivassem a promoção da habitação; combinar soluções habitacionais com iniciativas de geração de renda e buscar a diversidade social nos bairros centrais.

Novamente, o destaque para a idéia da diversidade que, como vimos anteriormente, serviu às justificativas usadas para realizar a atração e articulação com o capital privado ("pluralidade econômica"), para gerar os estímulos à "volta” de famílias de renda média (“diversidade social”), e para embasar algumas das ações de atenção aos grupos vulneráveis e de geração de emprego e renda. Vê-se, portanto, a construção de um discurso que tem se prestado a diversos objetivos antagônicos - criando uma confusão ideológica em torno da intervenção em áreas centrais, podendo significar até uma naturalização das desigualdades sociais e econômicas existentes (FCV, 2001). Ao mesmo tempo em que tal discurso demonstrou um princípio urbanístico democrático, buscando garantir a permanência de moradores de baixa renda na área central foco da reabilitação, mascarou as intenções de valorização e alterações dos padrões de usos - vistas como meio eficaz de alcançar a reabilitação - atraindo novos investimentos e usuários de maior poder aquisitivo.

De um ponto de partida condicionado pelas discussões e ambigüidades da reabilitação urbana também pelos formatos e princípios do BID - articulou-se dentro do Morar no Centro um conjunto de programas e modalidades de atendimento à demanda habitacional, prevendo construções novas ou reformas de edifícios existentes. Com vistas a atender faixas de renda mais baixas (até 3 salários mínimos), que tradicionalmente não conseguem acessar os financiamentos, foram propostas os seguintes programas e modalidades de atendimento:

i) PAR Reforma - Programa de Arrendamento Residencial, a partir de recursos da contrapartida local e da assinatura de convênio com a Caixa Econômica Federal em 2001, prevendo a adequação de edifícios existentes ao uso habitacional para famílias com renda entre 3 e 6 salários mínimos;

\footnotetext{
${ }^{61}$ Segundo dados do IBGE (2000), nos 13 distritos enfocados pelo programa Morar no Centro, 21,12\% dos chefes de família ganhavam até 3 salários mínimos; 14,17\% entre 3 e 5 salários mínimos; 26,31\% entre 5 e 10 salários mínimos; $11,15 \%$ entre 10 e 15 salários mínimos; e 27,14\% mais de 15 salários mínimos (PMSP/SEHAB/Morar no Centro, 2004).
} 
ii) Bolsa Aluguel e Moradia Transitória, como apoio financeiro para locação de imóveis no mercado, destinado a famílias com renda entre 1 e 10 salários mínimos, removidas de áreas de intervenção pública, em situação de risco ou em espera por outras linhas de financiamento;

iii) Locação Social, para atendimento habitacional de famílias com renda inferior a 3 salários mínimos, por meio de aluguel subsidiado e com valor compatível com a renda da família beneficiária; e

iv) Programa de Cortiços, com intuito de melhorar as condições de moradia nos cortiços, através do cumprimento dos padrões de habitabilidade da Lei Moura (LM 10.928/91) e de financiamentos aos proprietários para reforma e adequação dos imóveis, com a condição de não alterar o valor dos aluguéis.

Esse último, retomando as discussões realizadas durante a gestão da Prefeita Luiza Erundina (1989-1992), envolvia ações de educação e informação aos moradores, para que fiscalizassem e cobrassem o atendimento de seus direitos e condições adequadas de moradia, o que seria reforçado pela atuação da Comissão de Intervenção em Cortiços (CIRC). Essa abordagem era tida como fundamental para a efetivação do programa, uma vez que a realização das obras dependia de ações fiscalizatórias e do envolvimento de proprietários. Previa também uma atuação conjunta com o PAC-BID da CDHU para a produção de novas unidades habitacionais que atenderiam as famílias relocadas devido ao necessário desadensamento dos cortiços a serem reabilitados.

Vale ressaltar o ineditismo dos programas de Locação Social e Bolsa Aluguel, trazendo um contraponto à idéia hegemônica da aquisição da casa própria como forma de solucionar a moradia popular. A Locação Social foi discutida por técnicos e movimentos de moradia, tendo como base experiências internacionais de constituição de um estoque público de habitação de aluguel a baixo custo e subsidiado, compatível com a renda das famílias atendidas, como ocorre no caso francês. A importância da proposição desse programa estava na possibilidade de atender famílias que não conseguem acessar as linhas de financiamento existentes, por falta de renda ou incapacidade de sua comprovação, ainda que durante sua implementação tenham ocorrido entraves, como as dificuldades da gestão condominial - um gasto mensal que muitas das famílias não podiam pagar.

Sua aplicação era vislumbrada para toda a cidade, mas a área central foi entendida como propícia à realização de um programa de locação, por ser caracterizada por grande percentual de 
domicílios alugados $^{62}$, concentração de moradores de cortiços - uma demanda em potencial - e possibilitar apenas financiamentos de valor mais elevado do que nas áreas periféricas, dificultando o atendimento à baixa renda pela aquisição (TSUKUMO, 2007). Os recursos previstos vinham do Fundo Municipal de Habitação, mas seriam retornados com o pagamento mensal dos aluguéis.

O programa de Bolsa Aluguel, além de se contrapor à idéia da aquisição da casa própria, era entendido como potencial gerador de aquecimento do mercado de aluguéis da cidade, permitindo a ocupação de unidades residenciais vazias. Sendo a Prefeitura mediadora do contrato, ficava assegurada a transação e tornava-se possível a moradia de aluguel para famílias de baixa renda, que num contrato comum dificilmente teriam como apresentar toda a documentação exigida.

Essas duas modalidades de atendimento foram aplicadas durante a gestão Marta, no âmbito da reabilitação da área central e contando com recursos do BID, como foi o caso do Parque do Gato e do edifício São Vito, ambos considerados projetos especiais. O São Vito integrava as propostas para a reurbanização da área do Parque Dom Pedro II, prevendo sua recuperação para habitação de interesse social, destinada aos moradores originais. Para a realização das obras, a Prefeitura desapropriou as unidades e contemplou as famílias com o auxílio da Bolsa Aluguel. No entanto, com a mudança de governo, os trâmites do projeto foram paralisados e em 2007 foi cortado o apoio financeiro às famílias, cogitando-se uma proposta de demolição do edifício, em conjunto com seu vizinho Mercúrio, a fim de abrir uma esplanada ligando o Mercado Municipal e o Palácio das Indústrias, apresentado como futura sede do chamado Museu da Criança. Tal situação provocou um movimento de reivindicação das famílias afetadas para que a Prefeitura garantisse a continuidade do pagamento da bolsa e tomasse providências quanto ao seu destino.

O projeto do Parque do Gato, localizado na foz do rio Tamanduateí, previa a remoção da favela existente nas margens do rio, a construção de unidades de HIS na porção afastada da margem, a ocupação da área não edificante com usos compatíveis (parque e equipamentos), e uma intervenção no geométrico viário da Marginal Tietê para melhorar o acesso à área. Foram executadas 486 unidades habitacionais, compondo um estoque público do programa de Locação Social e parte dos equipamentos coletivos foi construída.

Também compunham o Morar no Centro os Perímetros de Reabilitação Integrada do Habitat (PRIH), pautados numa forma de gestão e articulação de intervenções que pressupunha a atuação

\footnotetext{
62 A partir de dados do IBGE o documento de apresentação do programa Morar no Centro mostrou que em 1980, dos 183.354 domićlios particulares ocupados nos 13 distritos centrais, 60,2\% eram alugados (enquanto no município de São Paulo, essa porcentagem era de 40\%), e em 1991 do total de 187.080 domicílios particulares ocupados, 51,8\% eram alugados (enquanto no município a porcentagem era de 28,8\%). (PMSP/SEHAB, 2004 b).
} 
integrada do poder público. Diferente do atendimento habitacional em edifícios isolados, esse programa constituía-se em perímetros delimitados nos distritos centrais, caracterizados pela concentração de moradias precárias e imóveis subutilizados, coincidindo com a delimitação das ZEIS 3 - Zonas Especiais de Interesse Social, definidas no Plano Diretor Estratégico do Município em 2002 (mapa 5). Sua formatação, como a dos programas citados acima, deu-se a partir de debates entre gestores públicos, movimentos de moradia e assessorias técnicas, tendo como referência algumas experiências internacionais de recuperação de bairros históricos centrais, como os casos da Itália, Portugal e França - que abordaremos no capítulo 3.

O objetivo principal do PRIH era melhorar a qualidade de vida da população moradora e usuária de cada bairro/perímetro, suas condições habitacionais, os espaços públicos e a zeladoria urbana, através da atenção às especificidades locais e da mobilização e participação dos diversos atores sociais presentes no território - moradores, comerciantes, usuários em geral, entidades, etc. Envolvia também a articulação de ações para geração de emprego e renda, educação ambiental, melhoria de ruas comerciais, entre outros. Sua metodologia de atuação foi montada ao longo da aplicação do programa, pressupondo a necessidade de realizar um conjunto de intervenções integradas baseadas na participação da população local. Visava elaborar, em cada perímetro, diagnósticos participativos, planos de ação local de acordo com as principais problemáticas apontadas pela população e um Plano de Intervenção Integrada (PII). Esse último abarcava um Plano de Melhoria Ambiental, envolvendo projetos de micro-drenagem, melhoria de espaços públicos, acessibilidade e recuperação do patrimônio histórico; um Projeto de Construção Social para a formação e consolidação da gestão local participativa; e a Provisão Habitacional, com indicações de linhas de atendimento à demanda e de imóveis passíveis de intervenção.

Em busca de uma atuação integrada sobre o território, articulando os diversos tipos de intervenção que mencionamos, implantou-se através dos PRIH um modo de gestão urbana diferenciado, tão inédito quanto os programas e modalidades de atendimento habitacional focados no aluguel. Tal forma de gestão, a fim de estabelecer uma proximidade e o conhecimento da realidade de cada perímetro, envolveu a instalação de escritórios locais, denominados Escritórios Antena, como braços do poder público no território. Seu papel era coordenar os processos de discussão e mobilização da população, de elaboração e realização das intervenções do plano de ações e do PII. Além disso, como meio de garantir a implementação do Plano Integrado, procurou constituir em cada perímetro um Fórum de Entidades e um Comitê de Reabilitação (DM 44.401/2004), envolvendo representantes do poder público e da comunidade local. Através dessas instâncias de participação, pretendia-se articular as entidades existentes em projetos conjuntos e, principalmente, monitorar a realização das ações previstas nos planos. 
Percebe-se uma preocupação em atentar para as especificidades locais e a pluralidade de atores existentes, em que o Escritório Antena atuava como um mediador de conflitos e interesses, procurando priorizar a criação de "espaços de inserção e participação dos setores mais pobres" (Vitale et al., 2005). A idéia da diversidade a que nos referimos anteriormente, desta vez embasou a constituição de um processo de mobilização e gestão participativa que tinha como objetivo a articulação e capacitação de grupos de baixa renda - de moradores cortiços, catadores de materiais recicláveis, entre outros.

De 10 perímetros delimitados, 3 foram incluídos no financiamento do BID e tiveram suas ações iniciadas: PRIH Luz, PRIH Glicério e PRIH Brás; sendo que esse último não passou da etapa de diagnóstico $^{63}$. Na Luz e no Glicério ocorreu a montagem parcial das equipes dos Escritórios Antena, mas não sua instalação no território, o que permitiu, em parte, a realização das ações planejadas. Essas equipes conseguiram avançar na elaboração dos diagnósticos, dos planos de ação e dos Planos de Intervenção Integrada; na realização de intervenções de melhoria em espaços públicos (Praça da Vila Economizadora na Luz e Praça Triangular no Glicério); e na constituição do Comitê de Reabilitação e do Fórum de Entidades. No PRIH Glicério também foram organizados Grupos de Trabalho sobre os temas moradia, saúde e resíduos sólidos; e no PRIH Luz foi montada uma Comissão de Moradores de Cortiços. Vale apontar que, a partir da mobilização da população através dos Escritórios Antena, representantes dos PRIHs também participaram do Conselho do Orçamento Participativo da Subprefeitura Sé.

Quanto à melhoria e produção habitacional, as equipes dos Escritórios Antena iniciaram negociações com proprietários de conjuntos de imóveis subutilizados a fim de viabilizar a produção de HIS e HMP, utilizando os mecanismos e parâmetros urbanísticos das ZEIS 3. No caso do PRIH Luz, foi possível articular a construção de um conjunto habitacional de 370 unidades de HIS e 250 unidades de HMP, com incorporação da Construtora Engelux e linha de financiamento da Caixa Econômica Federal, em terreno da Cúria Metropolitana - galpões e terrenos vazios ou subutilizados, ocupados em sua maioria por depósitos e estacionamentos. Aplicando as regras das ZEIS 3, que incidiam sobre a área, foi previsto $50 \%$ da área construída total para HIS (20.250 m2), pelo PAR ou Crédito Associativo, e o restante para HMP. Conhecido como "25 de Janeiro", esse empreendimento teve sua demanda cadastrada no final de 2004, focando os moradores de cortiços e moradias precárias do bairro, cujo perfil se adequava à

\footnotetext{
63 Estava em negociação um convênio com a União Européia, para desembolso de recursos a fundo perdido, visando potencializar e consolidar as ações dos PRIH. Esse convênio envolvia a instalação de mais 4 Escritórios Antena, nos PRIHs Santa Cecília, Belém, Bom Retiro e Bela Vista; capacitação profissional e formação de cooperativas especializadas em reforma e restauro de edifícios; e programas de assistência social. Com a mudança de governo municipal em 2005 os PRIH foram abandonados e o convênio com a União Européia assinado, transformando-se no programa "Nós do Centro", com enfoque na assistência social.
} 
modalidade de atendimento prevista - renda entre 4 e 6 salários mínimos - e aos princípios do programa PRIH.

\section{MAPA 5: DELIMITAÇÃo DAS ZEIS E DOS PRIH}

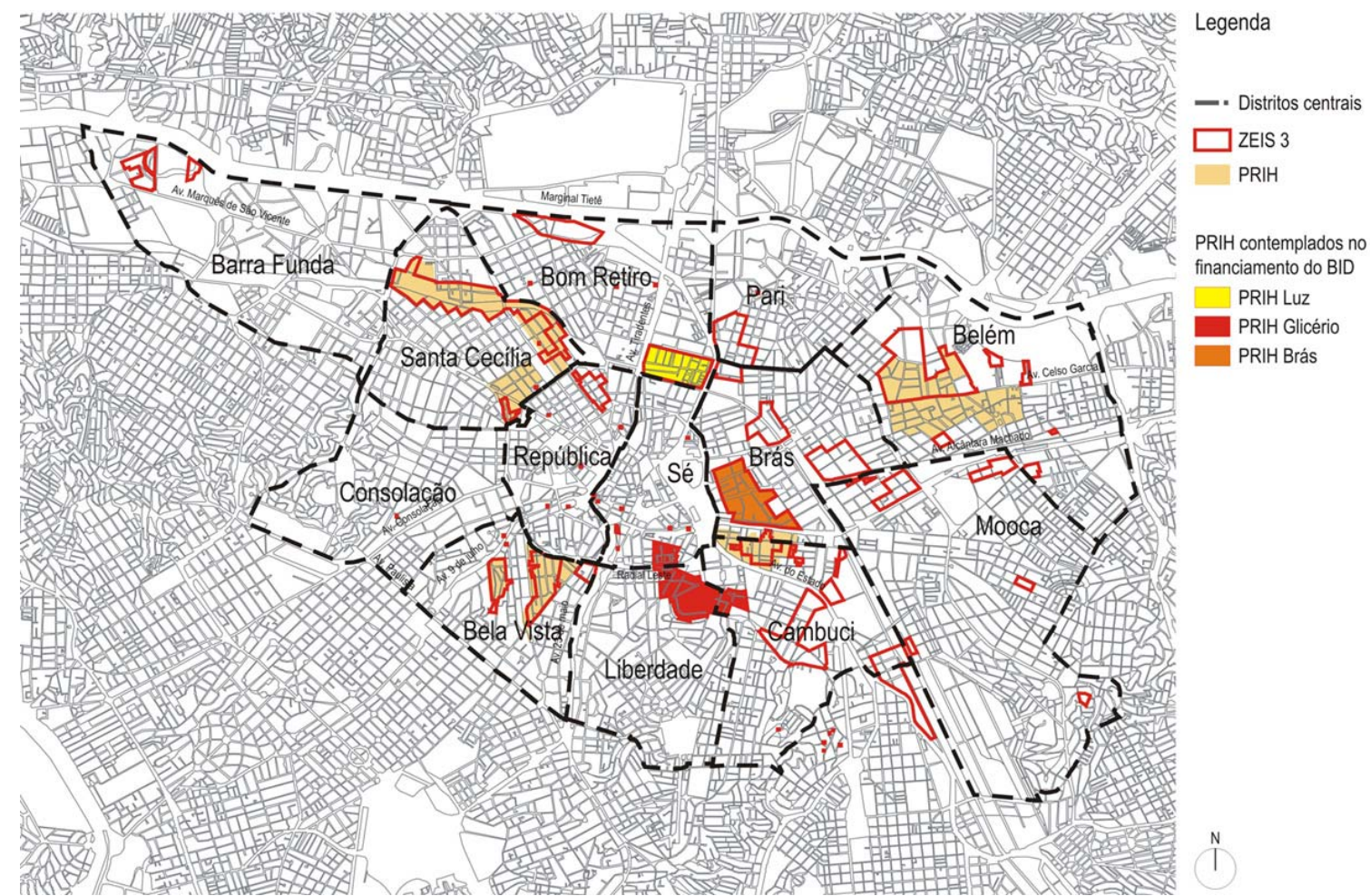

Fonte: LABHAB/LILP/CAIXA (2006), com adaptação da autora para destaque dos PRIHs contemplados com recursos do BID (tabela 1).

No entanto, alguns fatores dificultaram o andamento das negociações, como a necessidade de remembrar muitos lotes e a insistência da construtora em aumentar o valor final da unidade de HIS, contrariando a legislação (LABHAB/LILP/CAIXA, 2006). Com a mudança do governo municipal em 2005, as negociações foram paralisadas e a incorporadora deu continuidade ao empreendimento, porém realizando alteração na concepção inicial do projeto e desconsiderando a demanda já cadastrada, bem como os princípios e objetivos do PRIH, que também foi paralisado. Atualmente, as obras se encontram em estágio avançado, sendo que as alterações no projeto original resultaram na separação das unidades de HIS e HMP de um lado e outro da rua. Também houve alterações nas porcentagens de área construída para HIS e HMP, que passaram a contar com 40\% e 60\%, respectivamente, devido a mudanças nos parâmetros das ZEIS aprovadas em 2004 na nova Lei de Uso e Ocupação do Solo (LM 13.885/2004). As unidades foram vendidas no Feirão de Imóveis da CAIXA e por uma imobiliária, chegando a 51 mil reais no caso das unidades de HIS com 2 dormitórios (TSUKUMO, 2007). 
Além dos entraves para a realização desse empreendimento, houve uma série de dificuldades para a implementação do programa do PRIH como um todo, inclusive pela não instalação dos Escritórios Antena no território. Mesmo inserido no escopo do Programa Ação Centro, e em sintonia com seus objetivos de repovoamento e reabilitação, os PRIHs não conseguiram alcançar sua principal meta: realizar intervenções de melhoria e produção habitacional de interesse social. A exceção, além do empreendimento " 25 de Janeiro" citado acima, foi uma reforma em imóvel encortiçado, também localizado no PRIH Luz, por meio do Programa de Cortiços.

\begin{abstract}
A falta de peso político pode ser observada inclusive na própria Secretaria pela qual o programa foi implementado. Numa gestão que incorporou a bandeira da habitação social na área central e concretizou diversos empreendimentos, a falta de direcionamento de recursos para a implementação concreta de empreendimentos habitacionais e a dificuldade para a aplicação prática dos instrumentos (ZEIS 3) que estimulam e induzem a produção de habitação social no Perímetro, chama a atenção para essa fragilidade do Programa. (Vitale et al., 2005, p.21)
\end{abstract}

Portanto, as principais realizações no campo habitacional até o final de 2004 focaram empreendimentos isolados, fora das áreas delimitadas como PRIH, o que não deixa de ser significativo. Pelo programa PAR, estavam em andamento 13 empreendimentos, dos quais 5 foram concluídos, totalizando 464 unidades habitacionais: Riskallah Jorge (167 UH - Unidades Habitacionais), Fernão Sales (54 UH), Labor-Brigadeiro Tobias (84 UH), Maria Paula (75 UH) e Olga Benário Prestes-Celso Garcia (84 UH). Quanto à Locação Social, estavam em andamento 15 empreendimentos e foram realizados apenas 2: Parque do Gato (486 UH) e Olarias (137 UH), totalizando 623 unidades habitacionais ${ }^{64}$. Também foram realizadas as obras de cinco cortiços em que a Prefeitura tinha estabelecido convênio com as associações de moradores, ainda na gestão Luiza Erundina (1989-1992), a saber: Vila 25 de Janeiro (33 UH), Casarão da Rua do Carmo (25 UH - em obras), Imoroti (8 UH), Eiras Garcia (15 UH) e Pedro Fachini (12 UH).

Conforme a tabela 3 e o gráfico 3 a seguir, o Morar no Centro viabilizou considerável quantidade de unidades habitacionais, em comparação com gestões municipais anteriores. Alguns estudos recentes elaboraram análises sobre a questão da habitação social no centro, enfocando a experiência da gestão Marta Suplicy. Apesar de apontar alguns dos entraves na implementação dos programas, Diogo (2004, p.152) destaca que a política habitacional dessa gestão municipal representou uma tentativa de "sair da esfera das ações pontuais e atuando, pela primeira vez, na reforma de edifícios vazios e ociosos".

\footnotetext{
${ }^{64}$ Entre os que estavam previstos pelo PAR, as ocupações da Rua do Ouvidor e Prestes Maia sofreram ação de despejo em 2005 e em 2007, respectivamente e o projeto do Hotel São Paulo foi concluído em 2006. Entre os empreendimentos previstos pela Locação Social, o da Vila dos Idosos (150 UH) foi entregue em 2007. Além disso, em 2004 foi realizado um concurso nacional de idéias para 2 empreendimentos de locação, Cônego Vicente Marinho (235 UH) e Assembléia (160 UH), os quais não chegaram a ser executados.
} 
Já Tsukumo (2007, p.190), ressalta que foi produzido considerável número de empreendimentos habitacionais através de diversos programas - o que já havia sido iniciado nas gestões anteriores mas não chegou a se constituir uma política habitacional. Os instrumentos urbanísticos do Estatuto da Cidade regulamentados no Plano Diretor de São Paulo, como as regras da ZEIS 3 e o cumprimento da função social da propriedade - que gerou grande expectativa na viabilização de uma política - poderiam ter contribuído no avanço dessa produção, mas a Tsukumo (2007) aponta que seus resultados foram tímidos.

TABEla 3: UNIDADES HABITACIONAIS PRODUZIDAS E PREVISTAS (1992 - 2006)

\begin{tabular}{r|r}
\hline Produção Municipal & Quant. (UH) \\
\hline concluída antes de 2001 & 281 \\
\hline concluída entre 2001-2004 & 1126 \\
\hline concluída após 2004 & 302 \\
\hline Tnidades Paralisadas & $\mathbf{1 7 0 9}$ \\
\hline \hline Unidades previstas pela gestão Marta Suplicy (2001-2004) & $\mathbf{2 3 9 6}$ \\
\hline Unidades previstas por gestões anteriores & $\mathbf{3 4 8 0}$ \\
\hline
\end{tabular}

Fonte: Elaboração da autora a partir de dados da SEHAB trabalhados em LABHAB/LILP/CAIXA (2006) e Tsukumo (2007)

\section{GrÁfICO 3: TotAL DE UNIDADES HABITACIONAIS PRODUZIDAS (1992 - 2006)}

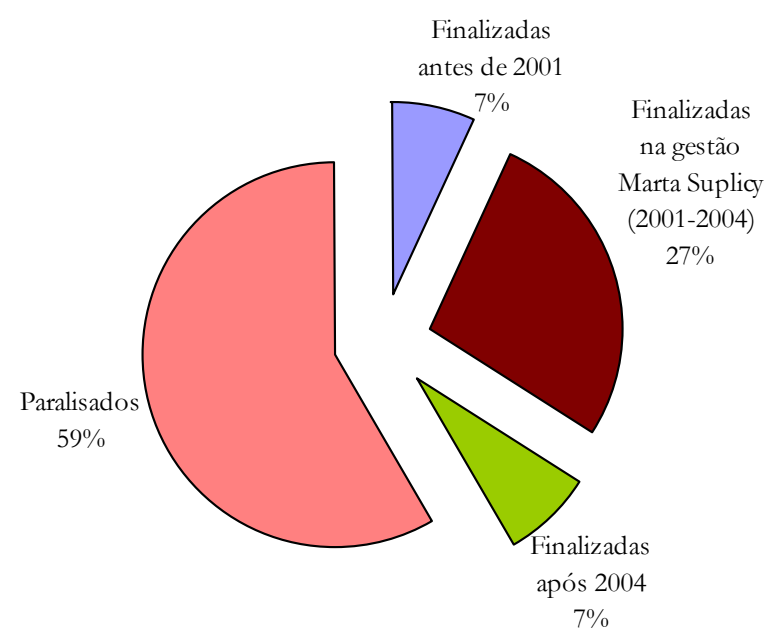

Fonte: Elaboração da autora a partir de dados da SEHAB trabalhados em LABHAB/LILP/CAIXA (2006) e Tsukumo (2007).

\subsection{Operacionalização, Gerenciamento, Monitoramento E}

\section{AVAliaÇÃo}

Como já comentado, para aprovar o programa junto ao BID a Prefeitura teve que atender diversas exigências relativas aos princípios do banco quanto à recuperação de áreas urbanas consideradas degradadas, o que se deu de forma imbricada com as regras operacionais e o 
formato das documentações exigidas. A transferência da coordenação do programa da ARSÉ para a EMURB, no começo de 2002, representou uma mudança de postura do governo municipal frente às negociações com o banco e à forma de gestão das ações, que passou a ter um caráter "estratégico-empresarial”. Segundo Silva (2004, p.28), percebeu-se a "necessidade de um arranjo institucional que possibilitasse uma interlocução mais intensa com setores da sociedade civil e com o setor empresarial em especial”. Mudava-se o enfoque da reabilitação da área central, apesar de se ter mantido muitos dos programas e ações constantes no Plano Reconstruir o Centro de 2001, que embasou a carta-consulta de março 2002.

\footnotetext{
Por um lado, as incumbências do dia a dia, assim como o perfil institucional e profissional de uma Administração Regional não eram os mais indicados para uma atividade de planejamento estratégico, mesmo se tratando da Administração Regional da Sé. Por outro lado, EMURB tinha toda uma história e expertise justamente ligada à recuperação urbanística e às intervenções na área central. (SILVA, 2004, p.28)
}

Ao seguir as recomendações e exigências do banco - o que, em parte, era compartilhado pelos técnicos locais - a Prefeitura explicitou um conjunto de princípios e estratégias de caráter neoliberais, retomando, em certa medida, o caráter da Carta-Consulta de 1997. Não que o Plano Reconstruir o Centro tenha sido isento de princípios de mesmo caráter - intervenções em grandes áreas urbanas e flexibilização da legislação urbanística vigente, visando à atração de capital privado - o que foi, inclusive, objeto de críticas de alguns atores sociais como o Fórum Centro Vivo (2001). No entanto, as mudanças na formulação do programa explicitaram os pressupostos da necessidade de flexibilizar a gestão pública sobre o território, de realizar parcerias com a iniciativa privada, atraindo investimentos e captando recursos, e de executar projetos urbanos indutores dessa atração, o que garantiria as transformações desejadas na área central e a recuperação dos custos do programa - trataremos desse último aspecto no capítulo 3.

Sendo o órgão executor e coordenador do programa, a EMURB fazia a intermediação direta com o BID, administrando os contratos, realizando a parte contábil-financeira, fiscalizando e controlando a utilização dos recursos (decreto municipal 44.090/03, art. 2º, bem como se responsabilizando pela pré-aprovação do Regulamento Operacional (RO) - documento que definiu os termos e condições do programa. Através dela seriam apresentadas as solicitações de desembolsos dos recursos e justificativas de gastos, e preparados os relatórios de andamento exigidos pelo BID.

Toda a operacionalização do programa deviria seguir as normas do banco relativas aos termos de referência, editais, contratação-licitação, documentação para compromisso de gastos, autorizações de pagamento e prestação de contas - Normas Gerais, Anexos A, B e C do contrato (PMSP/EMURB, 2004a). As licitações realizadas no âmbito do programa, a partir de certo valor 
e que envolvessem recursos do empréstimo, deveriam ser internacionais e de acordo com a capacitação técnica, sem análise de preço, numa concorrência aberta a empresas de países com capital no BID, sobrepondo-se a lei brasileira de licitações (Lei Federal 8.666/93) ${ }^{65}$. Para cumprir esses procedimentos, o banco exigia a contratação de uma empresa privada gerenciadora - uma terceirização da gestão pública - entendida como uma forma de dar agilidade aos trâmites operacional-burocráticos do programa. No entanto, como veremos no capítulo 3, a despeito dessa exigência do BID, montou-se um conjunto complexo de procedimentos dentro da própria administração pública, com coordenação da EMURB - órgão executor - em articulação com representantes das secretarias - os subexecutores. Hoje, porém, foi contratada uma gerenciadora, a qual se instalou dentro do espaço físico da EMURB.

Outra exigência do BID - padrão em seus contratos de financiamento - foi a montagem de um sistema de monitoramento e avaliação do programa, o que se deu através da contratação de uma instituição externa a Prefeitura - concorrência ganha pela Fundação Instituto de Pesquisas Econômicas (FIPE). Esse sistema contou com indicadores de avaliação das ações (Marco Lógico) e uma descrição detalhada da situação do centro antes do início das intervenções (Linha de Base), o que seria "o ponto de referência para aferição dos efeitos e impactos que decorrerem de sua execução" (PMSP/EMURB/FIPE, 2003, p.2). A elaboração dos indicadores teve como base o estudo do consultor Remy Prud'homme (2002) sobre os impactos econômicos da realização do programa, condicionando a avaliação do mesmo por uma lógica econômica de "sucesso" das ações, como será abordado mais adiante e destacado no capítulo 3.

Tal conjunto de indicadores constou no Regulamento Operacional, o qual teve que passar por aprovação do banco até o momento da primeira liberação de recursos do financiamento. Segundo o contrato de empréstimo, o Marco Lógico e a Linha de Base - a qual deveria ser aprovada pelo banco em até 3 meses após a vigência do contrato - seriam utilizados para a elaboração das avaliações anuais, que deveriam ser entregues em 15 de dezembro de cada ano, "seguindo a metodologia acordada com o banco" (cláusula 4.06 ii). Também constou do contrato necessidade de realizar uma avaliação intermediária, num prazo de 3 anos após o início de sua vigência ou quando fossem comprometidos $50 \%$ dos recursos do financiamento; e a entrega de um relatório de avaliação ex post (cláusula 4.07), após 12 meses do último desembolso, a ser elaborado com recursos da Prefeitura (o mutuário).

\footnotetext{
65 Arantes (2004) aponta que sobre esses procedimentos operacionais "não há dialogo nem meio-termo", devem ser cumpridos de qualquer forma, na medida em que "são as regras do banco e não as regras locais as que valem". Essas regras compõem, portanto, o modelo de gestão pública trazido pelo BID, modelo esse que "vem de fora", como veremos no capítulo 3.
} 
O conjunto de indicadores definido no Marco Lógico incluiu: "indicadores de atividade ou resultado", que descrevem os produtos/tarefas realizados, de acordo com prazo, quantidade e qualidade; "indicadores de avaliação de efeito e impacto" das ações, medem os resultados e impactos com relação ao propósito e finalidade do programa, de cada componente; e “indicadores de acompanhamento da população vulnerável”. Também foram definidos “indicadores de referência”, considerando condições externas ao programa que têm implicações nos resultados esperados, a saber: taxa de desemprego do Município e da Região Metropolitana de São Paulo; outros investimentos do Governo do Estado e do próprio poder público municipal na área de intervenção; e atuação dos movimentos de moradia na área central (principalmente as ocupações de edifícios vazios).

Os indicadores de "acompanhamento da população vulnerável" envolveram o monitoramento da: variação do número de moradores de rua; existência de ações violentas ou estigmatizadas em relação a eles; variação do número de imóveis utilizados como cortiços, pensões ou outra forma de moradia precária; variação no número de pequenos negócios; e variação da renda média dos ambulantes com Termo de Permissão de Uso (TPU). Tais indicadores foram montados com base no pressuposto de que as ações do programa gerariam efeitos "não planejados e indesejados" (PMSP/EMURB/FIPE, 2003), especificamente a expulsão de grupos de baixa renda da área central, devido ao processo almejado de revalorização imobiliária, transformação do perfil econômico e melhoria urbana.

Moradores de rua, pequenos comerciantes e moradores de habitações precárias e cortiços são alguns dos grupos que poderiam ser expulsos, fazendo com que um dos objetivos explicitados pelo programa não fossem cumpridos - realizar uma reabilitação com “inclusão social” em que essa população se apropriasse dos benefícios gerados. Vê-se aqui a mesma preocupação que norteou a inserção das iniciativas de atenção dos grupos vulneráveis, geração de emprego e renda e de habitação social no Ação Centro. Portanto, assumiu-se que o programa iria gerar "gentrificação", uma vez que todos os investimentos realizados acarretariam valorização imobiliária e, a maioria deles, atração de novos investimentos privados e usuários de maior poder aquisitivo.

Se por um lado houve a preocupação com os efeitos negativos das ações do programa, procurando "identificar, o mais rapidamente possível, eventuais impactos negativos causados a estas populações", por outro, os principais indicadores do Marco Lógico eram de caráter econômico - os "indicadores de avaliação". Com eles buscava-se aferir o aumento de estabelecimentos de serviços com produtos de maior preço unitário; maior número de 
lançamentos imobiliários; aumento da arrecadação pública; entre outros aspectos. Ou seja, explicitava-se uma racionalidade de "recuperação dos custos do projeto", comum nos financiamentos do BID, como veremos no capítulo 3, refletida na intenção do programa em operar um processo de recuperação do centro que resultasse numa transformação de sua dinâmica econômica e em sua valorização imobiliária.

Indagamos, portanto, quanto ao propósito dos indicadores de "acompanhamento da população vulnerável", uma vez que, para garantir sua permanência na área central, deveria ser implantado o controle efetivo do poder público sobre os mecanismos de mercado, da especulação e valorização imobiliária, viabilizando a execução de uma política habitacional que atendesse populações de baixa renda, por exemplo. E o Marco Lógico deveria contar com indicadores correlatos. O monitoramento de efeitos "negativos", a nosso ver, funcionaria como um paliativo, uma vez que o objetivo último do programa de reabilitação do centro parecia ser operar uma retomada econômica da área - sua valorização - e alcançar a transformação de seu padrão de usos e ocupação.

Nesse sentido, os principais indicadores do sistema montado eram os "indicadores de avaliação de efeito e impacto" (anexo 4), que buscavam aferir as transformações proporcionadas pelo programa nos períodos das avaliações anuais e final e, por isso, também foram considerados para a elaboração da Linha de Base. Conforme aponta o documento de revisão da Linha de Base elaborado pela FIPE em 2006 (durante a atual gestão Serra/Kassab):

Finalidade do programa Ação Centro é promover o desenvolvimento econômico e social da área central de São Paulo, com diversidade. O seu propósito é manter, criar e tornar mais atraente as condições para o exercício das atividades privadas nesta área. Finalidade e propósitos continuam, portanto, integralmente mantidos na atual versão do programa, bem como seus indicadores. (EMURB/FIPE, 2006, p.87)

A partir desse "propósito" e "finalidade" do programa, os indicadores visavam contabilizar: o aumento da especialização terciária da área central em relação ao restante da cidade; a variação do tamanho do mercado efetivo de trabalho na área central (almejando aumento de 0,5\%); a variação dos salários gerados na área central em relação ao restante da cidade; o crescimento dos valores lançados de ISS, ITBI e ICMS ${ }^{66}$ em relação ao restante da cidade; e o aumento do consumo de energia elétrica (residencial, comercial etc.). Percebe-se que tais indicadores eram condizentes com o objetivo do programa de "reverter o processo de degradação e desvalorização afetiva do Centro da cidade" (PMSP/EMURB, 2004a) mediante atração de investimentos privados, instalação de novos usos terciários, de moradores de renda média e órgãos do poder público. Ou

${ }^{66}$ ISS - Imposto Sobre Serviços; ITBI - Imposto sobre Transação de Bens Imóveis; ICMS - Imposto sobre Circulação de Mercadorias e Prestação de Serviços. 
seja, por esses indicadores se pretendia aferir o alcance do propósito mencionado acima e que também constou no Marco Lógico do programa (PMSP/EMURB, 2004d).

Os indicadores relativos ao componente "Reversão da Desvalorização Imobiliária e Recuperação da Função Residencial" também explicitaram o objetivo do programa, procurando medir: o aumento dos valores imobiliários (aferido pelos valores de aluguéis); a diminuição da taxa de desocupação de imóveis residenciais; e o aumento em 10\% da superfície aprovada para construções e reformas de imóveis residenciais. Curioso notar que nenhum indicador - com exceção dos "indicadores de atividade ou resultado", específico de cada ação - procurou medir, por exemplo, a melhoria das condições de habitabilidade da população moradora de cortiços, considerando sua permanência na área mediante a realização dos programas habitacionais.

Relacionando-se ao objetivo de melhorar o ambiente urbano do centro, no sentido em que apresentamos as ações do programa anteriormente, foram criados indicadores baseados na opinião pública positiva quanto à sensação de segurança, ao ambiente urbano, à qualidade dos serviços de transporte público e circulação de pedestres e com relação ao centro em geral. São indicadores que avaliariam os impactos das ações integrantes dos componentes "Transformação do Perfil Econômico e Social", "Recuperação do Ambiente Urbano" e "Transporte e Circulação", condizentes com a necessidade de construir um "ambiente favorável" para que setores da iniciativa privada tornassem a investir no centro.

Por fim, é importante destacar que a exigência de montar um sistema de avaliação e monitoramento refletiu o pressuposto do BID em relação ao "sucesso econômico" do programa. Ou seja, a partir dos indicadores criados, percebe-se a intenção de que as ações realizadas gerassem uma alteração da dinâmica econômica e imobiliária da área central e possibilitassem a sustentabilidade e recuperação dos investimentos realizados pelo programa. Nesse sentido, os indicadores de avaliação se relacionavam diretamente com dois fatores imbricados:

i) mudança no perfil dos moradores, freqüentadores e usos instalados, passando a contar com população de maior poder aquisitivo e atividades mais sofisticadas, com produtos e serviços mais caros e;

ii) maior arrecadação pública ("recuperação dos custos do projeto") mediante maior número de empresas instaladas, com perfil mais sofisticado (pagando mais ISS e ICMS), aumento dos valores fundiários e imobiliários, com valores venais e de referência maiores, pelos quais se calcula os montantes lançados de IPTU e ITBI.

A instalação de empresas e moradores com maior poder aquisitivo seria essencial para alcançar a sustentabilidade econômica da reabilitação da área central, pois esses teriam capacidade financeira 
para manter seus imóveis e o padrão do ambiente urbano, e gerariam aumento da arrecadação pública. Segundo Silva (2004:15) “repovoar o Centro é (...) um elemento estratégico de reabilitação do Centro, que contribuirá para a sustentabilidade desse processo". A atração desses grupos, por sua vez, dependeria de uma contínua articulação com setores da iniciativa privada, estabelecendo uma agenda comum para o centro. O documento Informe de Proyecto destacou essa estratégia:

O alcance dos objetivos do programa depende da sustentabilidade do processo de reabilitação do centro. Para garantir esta sustentabilidade, se conformará na EMURB o Conselho Executivo Ação Centro, conformado por 12 representantes dos vários grupos sociais representativos da problemática do Centro, estabelecendo um nexo entre a atividade estatal e a cidadania, que contribua para a articulação e coordenação entre os atores públicos e privados. (BID, 2004a ,p.34, item 4.30)

Dessa forma, a conjugação entre os indicadores de caráter econômico e aqueles criados a partir da preocupação com os efeitos de "gentrificação" ("indesejados") da reabilitação, refletiu uma ambigüidade do Programa Ação Centro. Assim como na tentativa de articular as ações de indução de novos investimentos e as iniciativas de atenção aos grupos vulneráveis e, principalmente, de habitação social, procurou-se inserir estratégias díspares no mesmo "propósito" e "finalidade" do programa, construindo um discurso (com "diversidade", "pluralidade") que deveria servir a todas essas estratégias. $\mathrm{Na}$ medida em que se procurava "manter, criar e tornar mais atraente as condições para o exercício de atividades privadas na área", redinamizando sua economia e valorizando seus imóveis, criavam-se entraves à realização dos programas de moradia popular - dependentes do controle da valorização imobiliária - à manutenção dos pequenos comércios e serviços. Conseqüentemente, aceitavam-se os efeitos de expulsão dos usos populares, moradores e freqüentadores de baixa renda. 


\section{CAPítulo 2. DEgRadaÇão E NECESSIDAde de REVITALIZAÇÃo}

Neste capítulo, procuramos mostrar como foi construído um pensamento dominante da degradação da área central de São Paulo e da necessidade de sua revitalização, a partir da identificação de diversos fenômenos espaciais, sociais e econômicos. Para tal, analisamos algumas das interpretações existentes sobre as transformações da área central, formuladas por setores do mercado imobiliário ou grupos de empresários, pesquisadores acadêmicos e pelo poder público.

Já na década de 1970, os diagnósticos apresentados em documentos do poder público municipal destacavam mudanças na área em relação aos anos anteriores, caracterizando a degradação e novas tendências de expansão dos espaços centrais - o centro propriamente e os bairros centrais. Desde então, mas principalmente a partir da década de 1990, o entendimento de que o cento se deteriorou, ou está em declínio, foi amplamente difundido, em geral, sem abarcar a complexidade das transformações da área, suas mediações com o processo de produção do espaço urbano da metrópole, ou mesmo sem apontar as disputas políticas que as permeiam. Restringia-se à descrição de fenômenos percebidos ou a uma lógica de causa e efeito entre eles, associando a degradação do centro ora com a presença de camadas de baixa renda, comércio popular e informal, ora com a propalada idéia de "globalização", o que teria gerado seu abandono e a localização de empresas do “terciário avançado" em outras áreas da cidade.

Essa idéia de degradação justificou grande parte das iniciativas do poder público para a recuperação do centro, em especial na década de 1990, contribuindo para a consolidação de um modelo de intervenção urbana de cunho neoliberal, pautado na flexibilização do papel do poder público como meio para a atração de investimentos privados. Entendia-se que a revitalização do centro deveria permitir sua redinamização econômica e valorização imobiliária, revertendo o quadro de degradação. 
No entanto, veremos que diferentes entendimentos sobre a problemática do centro e da área central corresponderam a interesses distintos e conduziram à elaboração de diferentes propostas para sua recuperação, muitas vezes com objetivos antagônicos. Algumas interpretações ressaltaram que as transformações da área central de São Paulo permitiram sua apropriação pela maioria da população e, ao contrário da própria idéia de degradação, geraram um centro metropolitano e deselitizado (FELDMAN, 2004). A partir dessa interpretação, foram concebidos programas e ações que procuravam garantir a fixação da população de baixa renda e a manutenção de usos populares na área central.

A partir dessa análise, identificamos lacunas e contradições nas explicações sobre as transformações da área central e vimos que foram formulados discursos ideológicos ${ }^{67}$ sobre o centro e suas atuais problemáticas, justificando as propostas de revitalização do mesmo. Desta forma, procuramos compreender o que realmente ocorreu nesta porção da cidade, à luz de algumas discussões realizadas por autores que se debruçaram sobre o estudo da estruturação e produção do espaço urbano da metrópole paulistana. Como veremos, as transformações na área central da cidade vêm ocorrendo desde o início do século XX, com a abertura dos primeiros bairros residenciais de alta renda. Um processo que estabeleceu diferenciações internas à área e constituiu um espaço central - o centro propriamente e os bairros centrais de seu entorno - que não é, e nunca foi homogêneo, ainda que as classes dominantes tenham exercido o controle sobre sua produção e criado um espaço de representação de seu poder político e econômico.

\subsection{Primeiros Diagnósticos DA DEgRAdAÇão E INICIATIVAS DE REVITALIZAÇÃo (DÉCADAS DE 1970 E 1980)}

Com base na identificação de fenômenos espaciais, sociais e econômicos formulou-se uma idéia comum de degradação, recorrente em documentos oficiais do poder público, servindo de embasamento aos programas, projetos e obras de revitalização da área central, cujas primeiras iniciativas remontam a meados da década de 1970 (DIOGO 2004; KARA-JOSÉ, 2007). A idéia de revitalização ou reabilitação urbana, que havia surgido na Europa e nos Estados Unidos no

\footnotetext{
$67 \mathrm{O}$ conceito de ideologia utilizado nesse trabalho pauta-se na definição de Chauí (2005), entendendo-a como um "sistema ordenado de idéias ou representações e das normas e regras como algo separado e independente das condições materiais, visto que seus produtores - os teóricos, ideólogos, os intelectuais - não estão diretamente vinculados à produção material das condições de existência. E, sem perceber, exprimem essa desvinculação ou separação através de suas idéias” (CHAUİ, 2005, p.62). Isso não significa que a ideologia seja uma idéia falsa ou sem base material na realidade, mas que se constitui numa representação invertida ou camuflada dessa mesma realidade. Utilizando-se de certos mecanismos, a produção da ideologia serve ao estabelecimento e manutenção do domínio de grupos sociais hegemônicos, de seu poder político e econômico.
} 
final da década anterior, em contraponto aos preceitos modernistas de intervenção e planejamento, começava a ganhar espaço no conjunto de práticas urbanísticas paulistanas.

Um dos primeiros documentos que abordou a degradação e a revitalização do centro da cidade foi o "Projeto Centro" de 1975, elaborado durante a gestão Miguel Colassuono (1973-1975) pela Coordenadoria Geral de Planejamento (COGEP), enfocando a área delimitada pela contra-rótula viária (atuais distritos Sé e República). Em seus levantamentos e diretrizes, percebe-se a associação de algumas questões à idéia de degradação, como o declínio do uso habitacional devido à sua expulsão pelo aumento de atividades econômicas, sua popularização e a conseqüente desvalorização imobiliária, ainda que o esvaziamento tenha sido relativizado para diferentes subáreas do centro. Ou ainda, o congestionamento de automóveis, a falta de vagas de estacionamento e a convergência de fluxos de pedestres, decorrente da localização central dos terminais de transporte, gerando conflitos entre a circulação de automóveis e pedestres. A preocupação maior parecia ser em relação à implantação do metrô, que acirraria os problemas detectados, ao mesmo tempo em que poderia melhorar a acessibilidade da área e gerar (retomar) sua valorização.

O projeto caracterizou a área como a mais bem servida em infra-estrutura da cidade e, por isso mesmo, com potencial para a "revitalização das atividades terciárias e do uso habitacional", indicando a necessidade de elaboração de uma legislação específica que viabilizasse tal revitalização. O incentivo ao uso habitacional, por sua vez, não abordou a moradia social ou a melhoria de cortiços, que se concentravam, segundo os documentos, ao redor da área de estudo $^{68}$. Falava-se em modificar as características do parcelamento do solo através do incentivo ao reagrupamento dos lotes, taxar as áreas não edificadas no sentido de se estimular a edificação das mesmas e conceder isenções de impostos para determinados tipos de ocupação e uso.

Ainda integrou o projeto o seminário "Revitalização da Área Central", que contou com especialistas de países centrais do capitalismo e abordou os seguintes temas: circulação de pedestres e automóveis, estacionamentos, áreas verdes, reciclagem de edifícios, transporte coletivo, equipamentos culturais, esvaziamento do centro, renovação urbana, entre outros, debatendo casos nacionais e internacionais de recuperação de centros urbanos.

O segundo conjunto de documentos resultou do "Seminário Permanente de Debates", realizado no primeiro semestre de 1976, já na gestão Olavo Setúbal (1975-1979), recebendo o nome de

68 Também em 1975 foi elaborado pela SEBES-HABI o estudo "Diagnóstico do Fenômeno Cortiço no Município de São Paulo". Segundo Diogo (2004), o documento explicitava a preocupação com a ocupação dos antigos casarões pelas habitações subnormais, sendo que o arco Bom Retiro-Pari-Brás apresentava a maior concentração de cortiços no centro. O estudo estimou que $9,3 \%$ da população do município vivia em cortiços, totalizando mais de 554 mil pessoas e mais de 125 mil famílias. 
"Plano Integrado da Área Central". Também elaborado pela COGEP, tal documento explicitou uma tendência à revalorização no tratamento dos problemas do Centro, diante de suas repercussões na cidade, como a dispersão das "atividades centrais". O Plano Integrado foi o primeiro documento a problematizar o conceito de deterioração, apresentando-o sob seus aspectos econômico, social e físico: subutilização de equipamentos e infra-estrutura, gerando diminuição da rentabilidade dos investimentos; popularização de atividades de comércio e serviços, bem como de usuários; e degeneração do espaço construído, envolvendo a falta de conservação dos edifícios e o aumento dos congestionamentos. Ao discutir esses aspectos do conceito de deterioração, afirmava-se no documento a intenção de assumir uma posição "mais consciente e objetiva" (PMSP/COGEP, 1976, p.32) frente às problemáticas do centro.

\begin{abstract}
A partir desse conhecimento mais profundo e organizado do processo de deterioração urbana pode-se assumir uma posição frente ao problema, mais consciente e objetiva, extrapolando o conceito, hoje mais ou menos generalizado, que associa à deterioração um juízo de valor, fundamentalmente subjetivo, tendo por base a substituição e queda de padrão das atividades que ocupam uma determinada área. Essa linha de raciocínio tem correlação com uma visão elitista do problema que, em relação ao Centro, se traduz na nostalgia pela saída das atividades de elite e em desejo de recuperação e revitalização dos usos tradicionais, dos quais alguns ainda são representados na Área Central. Nesse sentido, é importante lembrar que a própria manutenção de certos usos tradicionais no Centro, acarreta a concentração de atividades de apoio (despachantes, corretores, etc), que devem também ser consideradas típicas da Área Central e não indicadores de deterioração ambiental (PMSP/COGEP, 1976, p.32).
\end{abstract}

Isso não significou uma abordagem diferente daquilo que se tornou dominante no debate sobre as problemáticas e intervenções no centro ao longo das décadas seguintes: congestionamento, popularização, obsolescência, estagnação, entre outros, entendidos como fatores da deterioração, a qual é tida como causa da fuga de empresas e da contínua expansão do próprio centro.

Por um lado, o Plano Integrado considerou o processo de fuga das atividades econômicas principalmente "comércio de luxo e profissionais especializados" - como um movimento de dispersão e deslocamento do centro ainda assistemático e indefinido. Propunha, portanto, que as futuras políticas para o centro considerassem uma articulação entre as tendências de centralização e descentralização da estrutura urbana, em especial no que tange a concentração de "atividades centrais". Mostrava preocupação com o grande aumento da oferta imobiliária nos novos centros sub-regionais - maior que a demanda real - e a ociosidade das edificações do centro tradicional. Por outro lado, destacou as dificuldades de acesso por automóveis e o crescente congestionamento no centro - aspecto físico da deterioração - como as principais causas do desenvolvimento dos centros mais periféricos, como aqueles que se desenvolviam na Avenida Faria Lima e na Marginal do rio Pinheiros (PMSP/COGEP, 1976, p.7). Nesse sentido, o tratamento dos problemas relativos ao congestionamento - aumento de automóveis, mistura de 
tráfego de passagem e local, convergência de pedestres pela localização central dos terminais de transporte, gerando sobrecarga dos calçadões, degeneração dos passeios públicos, e aumento da poluição sonora e atmosférica - seria fundamental para a melhoria do centro, permitindo seu adensamento funcional e, inclusive, a volta de algumas atividades econômicas.

Par tal, o Plano defendia a realização de diálogos com a iniciativa privada, a fim de conciliar as propostas públicas com as "leis do mercado". Apontou a necessidade de realizar melhorias urbanas que criassem condições favoráveis à instalação de atividades tradicionalmente centrais, contribuindo para a reversão do processo de dispersão, entre as quais destacamos: revalorização dos espaços abertos pela implantação das estações da linha Norte-Sul do Metrô; implantação e manutenção das ruas de pedestres; limpeza, iluminação e policiamento; controle e conservação do patrimônio. Nota-se, ainda que de forma embrionária, a idéia de aplicar recursos públicos em intervenções urbanas como estratégia de atrair investimentos privados; estratégia essa que se tornou dominante a partir dos anos 90.

Ambos os documentos - Projeto Centro e Plano Integrado - ainda destacaram que a estagnação da dinâmica imobiliária foi decorrência, principalmente, de parâmetros urbanísticos e edilícios restritivos e inadequados, o que gerou a má conservação do patrimônio construído. Propunham, portanto, a elaboração ou revisão da legislação urbanística, compatível aos objetivos da revitalização.

Os fenômenos descritos nos documentos - fuga, esvaziamento, congestionamento, estagnação e má conservação - foram considerados manifestações do declínio do centro; e sendo esse espaço a principal referência simbólica para toda a cidade, para sua identidade, era preciso revitalizá-lo. Tal enfoque também esteve presente no "Plano de Revitalização do Centro" da gestão Setúbal, do qual fez parte diversas obras de melhoria de espaços públicos, recuperação de edifícios de interesse histórico e da paisagem urbana ${ }^{69}$, elaborados em sua maioria pela EMURB.

A essa época, esboçavam-se críticas ao modelo de planejamento urbano moderno, considerado totalitário, tecnicista e descolado da realidade, iniciando uma crise dos paradigmas que haviam norteado os grandes planos urbanos da década anterior, como o PUB (Plano Urbanístico Básico de 1969). Ainda que de forma incipiente, eram introduzidos novos ideais arquitetônicos e urbanísticos inspirados em correntes internacionais que buscavam atentar para as especificidades

\footnotetext{
${ }^{69}$ Muitos dos edifícios e espaços públicos que passaram por intervenções tinham sido objetos de propostas anteriores na gestão Colassuono, através de estudos elaborados pela COGEP para a definição das zonas especiais Z8, correspondentes a perímetros envoltórios de imóveis de interesse histórico arquitetônico. Entre eles: Pátio do Colégio, Vale do Anhangabaú, galeria Prestes Maia, Rua 25 de Março, Parque Dom Pedro II, viaduto Boa Vista, Largo São Francisco, Vila Itororó, entorno de estações do Metrô.
} 
locais (COUTO, 1999; KARA-JOSÉ 2007), retomando a escala do desenho urbano. No caso do Plano de Setúbal, seu conjunto de intervenções pontuais tinha como objetivo atrair o interesse de setores do capital, revertendo a fuga de empresas em curso, seguindo exemplos de cidades de países do Primeiro Mundo.

Entre as obras mais emblemáticas (e polêmicas), pode-se citar o restauro do Edifício Martinelli, nos moldes do que se vinha fazendo em cidades européias: recuperação da fachada e modernização do interior. Primeiro arranha-céu da cidade (1934) e símbolo da elite paulistana, o edifício passou por processo de abandono e encortiçamento a partir dos anos 50 . Recuperá-lo foi um marco da política de revitalização da época, removendo as famílias moradoras de baixa renda e mantendo apenas aqueles que poderiam pagar pelas obras. Como aponta documento da EMURB, "mais uma vez o pioneirismo se fez presente pela união de particulares e governo participando num empreendimento inédito e de grande vulto” (PMSP/EMURB, 1979b).

De maior porte, as intervenções nas praças do metrô, envolvendo remodelação dos espaços abertos pela implantação das linhas norte-sul e leste-oeste, foram caracterizadas como "cirurgias urbanas", indutoras da revitalização dos espaços públicos do entorno das estações. A obra da Praça da Sé foi a mais polêmica, tendo descaracterizado seu traçado original, eliminando algumas quadras e o conjunto de edifícios, entre eles o conhecido Mendes Caldeira, que separava a Praça Clovis Beviláqua e a da Sé propriamente. Com altíssimo custo, a obra foi criticada pela perda da memória local e da escala humana (KARA-JOSÉ, 2007, p.50). O mesmo viés "arrasa quarteirão" também caracterizou a obra da estação República, que previa a demolição do Instituto Caetano de Campos. A mobilização de alunos e ex-alunos, atraindo interesse da imprensa, conseguiu reverter a situação e encaminhar o tombamento do edifício pelos órgãos de preservação. Informações no site do metrô são reveladoras da forma como eram realizadas as obras: “a construção da Linha 3-Vermelha, mais do que as outras, envolveu uma profunda renovação urbana, principalmente na vizinhança das estações, com a eliminação de trechos deteriorados da cidade" ${ }^{, 70}$.

Outras obras integraram esse Plano: a recuperação do viaduto Santa Ifigênia, integrando-se com a Praça São Bento (também criada em decorrência da estação do metrô); a construção da réplica de uma igreja de 1671 no Pátio do Colégio, causando polêmicas quanto ao conceito de patrimônio histórico e sua preservação; estudos para reurbanização do Vale do Anhangabaú que não foram levados a cabo; e a implantação dos calçadões, representando uma mudança significativa na

70 São Paulo (estado)/METRÔ. Historia Linha 3-Vermelha. São Paulo: METRÔ. Disponível no endereço eletrônico: http://www.metro.sp.gov.br/empresa/historia/vermelha/historia02.shtml . Acessado em 01/04/2007. 
organização da circulação na área central. Essa última, seguindo os exemplos de "diversas cidades do mundo", buscava racionalizar o tráfego e diminuir os congestionamentos, restringindo o acesso de automóveis na área interna a rótula viária central ${ }^{71}$.

Na gestão Colassuono, houve uma primeira iniciativa de restringir o tráfego de automóveis, com base na associação dos congestionamentos à fuga de empresas para outras áreas da cidade. Nesse sentido, buscava o renascimento de parte do centro (PMSP/COGEP, 1974), alargando calçadas e proibindo o acesso de carros em determinados períodos do dia. Partindo dos mesmos diagnósticos e coincidindo com a implantação do metrô, o Projeto "Rua de Pedestres" que integrou o Plano de Setúbal eliminou o leito carroçável de diversas ruas e realizou tratamento de pisos e de mobiliário urbano. Buscando transformar São Paulo em "uma cidade menos dura, menos fria e menos materialista", a idéia era retirar o tráfego de veículos das ruas mais centrais, priorizando o pedestre e seguindo a "determinação de valorizar o centro da cidade, suas atividades, sua paisagem" (PMSP/EMURB, 1979c).

Ainda compôs o Plano de Setúbal a criação da "Zona Azul”, seguindo os "moldes existentes nas grandes cidades, notadamente na Europa” (PMSP/EMURB, 1979a) ${ }^{72}$, além da implantação de estacionamentos nas proximidades da rótula viária, como nas Praças da Bandeira e Roosevelt.

A mesma preocupação com a circulação esteve presente em estudos elaborados pela Companhia de Engenharia de Tráfego (CET): Plano de ônibus da Área Central (POAC) de 1978 e o Plano de Operação de Linhas Tronco de Ônibus (POLT) de 1979. Ambos identificaram a existência de problemas na área central, que geravam ineficiências no sistema de transporte: distâncias excessivas de percursos a pé entre terminais; grande número de transferências/baldeações; excessiva concentração de ônibus nos corredores que acessam o centro.

Nota-se, portanto, que o enfoque na circulação e nos congestionamentos - tidos como causas da deterioração e da fuga de empresas - era latente nos documentos da época, caracterizando as intervenções realizadas e propostas. Construía-se a idéia de que a convergência de fluxos para o centro, dada pela estrutura rádioconcêntrica da cidade e, principalmente, pela forma de funcionamento do sistema de transportes, seria responsável pela intensificação do comércio de caráter popular, o qual passava a ser associado ao quadro de deterioração da área central.

\footnotetext{
71 A rótula viária central representa o chamado "Perímetro de Irradiação", termo cunhado por Ulhoa Cintra no início da década de 1920 e que viria a ser incorporado no Plano de Avenidas de Prestes Maia. Configura-se como um anel viário de irradiação dos fluxos que convergem ou saem do centro, dando acesso a diversos eixos radias de circulação. A área interna a ela compreende o que hoje seria a porção mais central dos distritos Sé e República, exatamente onde há calçadões.

72 Esse conceito havia sido introduzido pelo Programa de Ação Imediata de Transportes e Tráfego (PAITT), elaborado pelo Grupo Executivo da Grande São Paulo (GEGRAN) ainda em 1971.
} 
De fato, as inúmeras obras viárias realizadas com o Plano de Avenidas e, mais tarde, nos anos 50, a fim de acomodar o aumento do número de veículos, reforçaram a polarização da área central e transformaram alguns de seus principais espaços públicos em grandes estacionamentos. Ainda assim, a idéia de deterioração apresentada pelos documentos partia de interpretações isoladas dos fenômenos espaciais, sociais e econômicos em curso, raramente estabelecendo relações entre eles e o processo de produção do espaço metropolitano como um todo. Quando o fizeram, tomaram a deterioração como uma decorrência natural da expansão urbana, pautando-se em relações de causa e efeito entre os fenômenos, e não em relações de mútua interferência determinadas pela atuação de agentes sociais distintos.

O entendimento das transformações do centro, que relaciona sua crescente ocupação por usos e camadas populares com o quadro de degradação, permeou também a década de 1980, porém com menor destaque, uma vez que grande parte das agendas dos governos canalizou esforços e recursos em outras áreas da cidade. O enfraquecimento do regime militar e o processo de democratização explicitaram demandas sociais e fortaleceram os movimentos populares urbanos, o que refletiu nas atuações dos governos municipais no período. Nesse contexto, a gestão Mario Covas (1983-1985) dedicou a maior parte de suas propostas para os bairros periféricos, diminuindo a importância dada à área central (KARA-JOSÉ, 2007; DIOGO, 2004).

A abertura da Assembléia Constituinte retomou a discussão que havia sido iniciada nos anos 60, sobre a criação de mecanismos que permitissem aos poderes públicos intervir democraticamente no processo de produção do espaço urbano, buscando uma regulamentação para a política urbana. Tal discussão esteve presente na proposta do Plano Diretor de 1985, elaborada na gestão Covas pela Secretaria Municipal de Planejamento (SEMPLA), como se percebe no apontamento do texto quanto à necessidade de instituir "mudanças do regime jurídico da propriedade imobiliária urbana (...) especialmente mediante a adoção de instrumentos legais novos”, a fim de resgatar o déficit social da cidade (PMSP/SEMPLA, 1985a, p.17).

Ao mesmo tempo, a década de 1980 foi marcada pela crise econômica associada ao crescimento da dívida externa nacional, que recaía sobre as finanças municipais, reduzindo a quantidade de grandes obras realizadas até então pela Prefeitura, inclusive na área central. Muitas das iniciativas do período buscavam minimizar os gastos públicos, justificando a oficialização de parcerias entre os setores público e privado, a flexibilização da legislação urbanística, e a criação de isenções fiscais e tributárias, inspirando-se em exemplos internacionais de aplicação destes tipos de mecanismos. 
Entre os instrumentos urbanísticos propostos para a área, destacam-se aqueles cujo objetivo era incentivar a proteção do patrimônio histórico, mediante compensações aos proprietários dos mesmos pelos prejuízos decorrentes da limitação da preservação. $\mathrm{Na}$ gestão Covas foi regulamentada a Lei de Transferência de Potencial Construtivo (LM 9.725/1984) ${ }^{73}$, que permitia a comercialização e transferência do potencial construtivo de imóvel de valor histórico, localizados nas zonas especiais Z8-200, para outros imóveis nas proximidades. Já na gestão Jânio Quadros (1986-1988), foi criado um mecanismo de isenção de 50\% do Imposto Predial Territorial Urbano (IPTU) para imóveis localizados num perímetro delimitado na área central, ou para imóveis tombados por lei municipal, mesmo que localizados fora do perímetro. Em ambas as leis, a contrapartida era a restauração e conservação do imóvel preservado.

Essas leis foram norteadas pelo conceito do solo criado, com base no princípio da separação entre o direito de propriedade e o direito de construir. Como aponta Freitas (1995), o tombamento de um imóvel limita o direito de construir e não indeniza o proprietário, impedindoo de utilizar o potencial construtivo inerente ao seu imóvel, definido pelo coeficiente de aproveitamento determinado na lei de zoneamento vigente.

Um outro tipo de instrumento proposto no período, introduzido pelo Plano Diretor de 1985, foi a Operação Urbana, tendo como mecanismo principal a cessão de benefícios urbanísticos que atraíssem investimentos por parte do setor privado. Diante das limitações orçamentárias da $\mathrm{p}$

Prefeitura, a idéia era envolver a iniciativa privada em "conjuntos integrados de intervenção", visando cumprir com as diretrizes do plano e introduzir "uma forma inovadora de ação" em que o poder público é entendido como promotor do desenvolvimento urbano. A área central foi contemplada com 8 operações, visando reurbanização, adensamento habitacional, renovação, entre outros, devido seu quadro de deterioração e estagnação, resultado do deslocamento de atividades econômicas para outras áreas mais atrativas. As operações deveriam possibilitar “alterações importantes no padrão de uso e ocupação do solo (...) numa estratégia que viabilize a obtenção, em condições privilegiadas, de terra e recursos para fins públicos e de habitação popular" (PMSP/SEMPLA, 1985a). Utilizava-se o mesmo conceito de solo criado citado anteriormente.

No entanto, nenhum desses instrumentos surtiu efeito. As leis de incentivo para proteção do patrimônio não despertaram o interesse dos proprietários e o Plano Diretor da gestão Covas foi

\footnotetext{
73 Apesar de terem ocorrido discussões sobre mecanismo similar ainda na gestão Setúbal, foi apenas com essa lei que a transferência de potencial construtivo se tornou oficial em São Paulo. Com a aprovação do Plano Diretor Estratégico do Município de São Paulo em 2002, a Transferência do Direito de Construir foi ampliada para toda a cidade e a lei da gestão Covas revogada.
} 
retirado da Câmara Municipal na gestão Jânio, sendo substituído por outro projeto de lei. Um novo plano foi aprovado por decurso de prazo em novembro de 1988, tendo sua validade contestada na justiça, ficando anos subjudice.

O contrário ocorreu com o instrumento das Operações Interligadas, regulamentado em 1986 (gestão Jânio Quadros, 1985-1988) pela Lei do Desfavelamento (LM 10.209/86) e alterado em 1995 pela lei 11.773/95, tendo maior adesão de setores do mercado imobiliário, pois permitiam a flexibilização da legislação em áreas da cidade de seu interesse, especialmente no setor sudoeste (LABHAB/LILP/CAIXA, 2006). A gestão Jânio quadros, inclusive, foi marcada pelo "pacote de obras" viárias no setor sudoeste da cidade e, invariavelmente, aumentando a acessibilidade de automóveis ao centro. Mesmo que envoltas em inúmeras contestações, inclusive com sua suspensão e a instituição de uma CPI em 2001, as Interligadas se constituíram num marco inicial das políticas urbanas pautadas nas parcerias público-privadas, que viriam a se consolidar na década seguinte com a criação de outras Operações Urbanas, em diversas regiões da cidade.

As propostas de criação desses instrumentos alinhavam-se às críticas aos princípios modernos de planejamento e intervenção urbana, iniciadas na década anterior, as quais buscavam, entre outros aspectos, maior atenção ao tema da preservação do patrimônio histórico. Neste contexto, foi criado o Conselho Municipal de Preservação do Patrimônio Histórico, Cultural e Ambiental (CONPRESP, Lei Municipal 10.032/1985), possibilitando a aplicação do instrumento do tombamento em âmbito municipal. O Departamento do Patrimônio Histórico (DPH), que existia desde 1975, teve sua atuação fortalecida e um considerável conjunto de edifícios históricos começou a ser inventariado, especialmente no centro histórico e alguns bairros centrais.

Nesse período também surgiram as primeiras iniciativas de revitalização da área central através de projetos pontuais com enfoque na preservação do patrimônio e sua adaptação ao uso cultural, das quais se destacam aquelas para o bairro da Luz coordenadas pelo Governo do Estado. A primeira delas foi lançada como "Projeto Luz Cultural", a partir da lógica de minimizar os gastos públicos, com a estratégia de gerar uma "animação" cultural e fortalecer o turismo, a fim de desencadear um processo "natural" de revitalização do bairro. Seguindo modelos internacionais de recuperação de áreas urbanas consideradas degradadas, entendia-se que o bairro tinha forte vocação cultural, a qual deveria ser incentivada através de roteiros turísticos e guias do patrimônio ambiental-cultural, potencializando ações de "redescoberta". Segundo Kara-José (2007), destacam-se dois princípios que nortearam esse projeto: a idéia de criar um processo "indutivo", um efeito espontâneo de revitalização a partir de ações pontuais e de baixo custo; e a 
idéia de que o uso cultural é o mais adequado para garantir a preservação do patrimônio histórico arquitetônico, o que a autora denominou de "imperativo do uso cultural no patrimônio".

As mesmas idéias estiveram presentes no projeto de reforma da Vila Itororó de 1982 (gestão Reynaldo de Barros/Salim Curiati, 1979-1983), que havia se tornado moradia de famílias de baixa renda. A proposta pretendia uma mudança de uso da vila, transformando-a em espaços para restaurantes, belvederes e ateliês de artistas, removendo as famílias moradoras e esperando que sua reforma pudesse induzir a revitalização urbana do bairro onde se localiza, a Bela Vista. Entendia-se que os usos cultural, de lazer e turismo eram os "tradicionalmente compatíveis com a aura de excepcionalidade" de bens tombados (RODRIGUES, 2000, p.123). Porém, o projeto foi interrompido diante de críticas elaboradas pelo CONDEPHAAT ${ }^{74}$, especialmente pelo arquiteto Flávio Império, que o considerou seguidor de uma cultura "altamente folclórica" e "alienada". O arquiteto chamava atenção para questões não comumente inseridas nas discussões sobre o patrimônio, como a dinâmica social e a historicidade dos objetos culturais, referindo-se à importância da população moradora ${ }^{75}$ (RODRIGUES, 2000).

Esses princípios se tornaram dominantes a partir dos anos 90, assim como as parcerias públicoprivadas e a flexibilização da legislação urbanística, embasando muitos dos programas de intervenção na área central da cidade propostos a partir de então, inclusive o Programa Ação Centro.

\subsection{EMBATES ENTRE MODELOS: DIFERENTES ENTENDIMENTOS DE CENTRO (DÉCADA DE 1990)}

\subsubsection{O DIREITO AO CENTRO}

Na década de 1990, a temática da deterioração do centro e de sua revitalização ganhou força, numa retomada dos debates sobre o tema e dos projetos específicos, principalmente devido à atuação da Associação Viva o Centro, criada em 1991, reunindo alguns segmentos do capital e

\footnotetext{
${ }^{74}$ Conselho de Defesa do Patrimônio Histórico, Arqueológico, Artístico e Turístico do Estado de São Paulo. Uma nova proposta de intervenção na Vila Itororó foi apresentada em 2005, tendo os mesmos objetivos e diretrizes da proposta de 1982, e apresentado os mesmos aspectos polêmicos de remoção da população moradora em função da instalação de usos culturais e artísticos. As discussões atuais, porém, têm atentado para uma possível relocação das famílias moradoras da Vila em um empreendimento habitacional nas proximidades.

75 A questão dos cortiços não contou com intervenções concretas de melhorias, apesar de abordada em dois documentos do período: "Programa de Melhoria em Cortiços Existentes", como parte do Plano Habitacional do Município de 1983, da gestão Covas, e o estudo "Cortiço em São Paulo, Frente e Verso", de 1985, da gestão Jânio. Esses documentos se constituíram em levantamentos e proposições, incluindo a oferta de habitação de aluguel para faixas de renda entre 2 e 5 salários mínimos (DIOGO, 2004) e identificando os cortiços como moradia precária típica da área central. O que se percebe nesses documentos, em especial no segundo, é uma "vinculação do encortiçamento à deterioração urbana, entendida como processo no qual determinadas áreas são abandonadas pelos estratos sociais que a habitavam" anteriormente (PMSP/SEMPLA, 1985b, p.59).
} 
entidades em torno das problemáticas da região. Também se pode ver uma retomada da atenção dada à área durante a gestão Luiza Erundina (1989-1992), que ocorreu em meio a uma conjunção de fatores, inclusive cedendo às pressões da Viva o Centro, a fim de evitar seu isolamento político e garantir a governabilidade. Explicitavam-se as disputas políticas pela produção e apropriação do espaço urbano do centro, envolvendo diferentes entendimentos das transformações em curso.

Os diagnósticos realizados pela administração Erundina, com destaque para o relatório "São Paulo: crise e mudança", elaborado pela SEMPLA, apontavam o centro como espaço ocupado por população de diferentes faixas de renda e importante local de trabalho das classes populares, seja da parcela que mora na periferia ou daquela que mora no centro em habitações precárias. Ao mesmo tempo em que parecia destacar um sentido democratizante das transformações em curso, na constituição de um centro metropolitano, buscou estabelecer alguma relação com o processo de produção do espaço metropolitano. Como destaca o documento, "o sistema econômico, ao utilizar a cidade para sua reprodução (...) tem provocado maior disponibilidade de áreas urbanas e, consequentemente, aumento da ociosidade em outras” (PMSP/SEMPLA, 1991a, p.124).

Nesse sentido, ainda que pouco se remetesse ao termo deterioração ou degradação, tal documento enfocou a ociosidade da infra-estrutura urbana instalada como um dos principais problemas da área central, devido à sua subutilização nos horários noturnos - mesmo que a freqüência na área não tenha diminuído. Também apontou o processo de esvaziamento populacional, de ocupação por comércios e serviços populares, e de aumento significativo de moradores de habitações precárias e cortiços ${ }^{76}$, em especial a partir da década de 1980. Esse último, da mesma forma que o aumento de favelas, foi considerado decorrência de um contínuo empobrecimento da população e de mudanças no padrão periférico de crescimento urbano, agravando as dificuldades de famílias de baixa renda na aquisição de um lote na periferia e posterior autoconstrução.

Como destaca Frúgoli Jr. (2000), isso não significa que o governo petista tenha priorizado o centro, já que sua atuação ainda enfatizou as questões sociais e os problemas da periferia urbana, coerente com a linha política do partido. O que ocorreu foi uma tentativa de superar a dicotomia centro-periferia, uma vez que era identificado o caráter popular do centro, justificando a atenção

\footnotetext{
76 Identificou-se aumento de 1,3 milhões de pessoas moradoras de cortiços, entre 1980 e 1990 (de $18 \%$ para $28 \%$ do total da população do município). Já nos governos seguintes, foram contratados pela SEHAB dois levantamentos amostrais de cortiços na área central, ambos realizados pela FIPE, em 1993 e 1997. Na pesquisa de 1993 foi levantado que, do total da população encortiçada do município, 20\% estavam localizados na Administração Regional da Sé, correspondendo a 25\% (119.255) de sua população total. Também foi apontado que na AR-Mooca essa última porcentagem subiu para 30\%.
} 
dada a ele. Mesmo num contexto de disputa, em que o governo cedia a pressões, o objetivo principal de suas propostas para a área central era o aumento da qualidade de vida de seus habitantes, moradores e usuários de todas as classes sociais, através da melhoria de espaços públicos e das condições habitacionais, garantindo o "direito ao centro".

O conjunto de programas formulado pelas secretarias municipais contou com ações voltadas especificamente para parcelas do centro e determinados bairros centrais, ou que apresentavam desdobramentos neles, a fim de propiciar sua ocupação de forma democrática. Pode-se perceber o esforço na definição de conceitos e princípios norteadores dessas políticas, como no caso do "Projeto Cidadania Cultural" da Secretaria da Cultura, que ampliou e politizou o conceito de cultura, procurando inverter prioridades, remexer na lógica de consagrar apenas o já consagrado (FARIA, 1997) e recusar o uso ideológico da cultura (CHAUÍ, 1993) ${ }^{77}$. Buscando aproximar a política cultural da política urbana, o centro foi ocupado com diversas atividades, aulas, eventos e exposições, entendendo-o como porção da cidade onde se explicitam a pluralidade e os conflitos.

Nessa mesma linha, procurou-se repensar o conceito de patrimônio histórico, extrapolando o tratamento isolado de edifícios monumentais ao abarcar conjuntos edificados, construções comuns e o chamado patrimônio imaterial, envolvendo a paisagem urbana como um todo, o tecido social existente, os costumes e saberes. Segundo Déa Fenelon, então diretora do DPH, "bens culturais não são apenas aqueles tradicionalmente considerados dignos de preservação, produzidos e definidos pelos vencedores de cada época. Ao contrário, são os frutos de todos os saberes, todas as memórias de experiências humanas (...) todos aqueles que brotam de escolhas e ações coletivas" (FENELON, 1992, apud SOUZA e GARCIA, 1997, p.73).

No entanto, muitos projetos de recuperação do patrimônio histórico enfocaram o tratamento de edifícios monumentais, associados à recuperação da importância simbólica do centro, um dos objetivos da administração. Entre as ações mais emblemáticas, destaca-se o restauro do Palácio das Indústrias para abrigar o Gabinete da Prefeita, em conjunto com um projeto de intervenção em todo o Parque Dom Pedro II e prevendo a transferência das secretarias municipais para edifício projetado por Lina Bo Bardi. Seu objetivo era aproximar a população de seus governantes e contribuir com o projeto de recuperação do centro (PMSP/SMC/DPH, 1992). Outros reconhecidos bens de valor histórico do centro receberam atenção nos documentos

\footnotetext{
77 Segundo Chauí (1993), o "Projeto Cidadania Cultura" se baseou na recusa de três principais tradições do uso da cultura: a cultura oficial produzida pelo Estado que serve para legitimar sua própria ideologia (do Estado Novo e do regime militar); a cultura populista do final dos anos 50 e começo dos 60, dando uma "aura messiânica" àquilo que é considerado verdadeiramente "do povo"; e a cultura de corte neoliberal definida pelos conteúdos e padrões do mercado, alinhando-se à defesa pela minimização do papel do Estado.
} 
oficiais, com propostas de restauro, como o Teatro Municipal, a Biblioteca Mario de Andrade e as Casas Históricas. Essas últimas foram associadas a programas da Secretaria da Cultura que envolviam ações educativas e o "direito à memória".

Também foi proposto o "Programa de Ordenação da Paisagem da Área Central", com coordenação da Comissão de Proteção à Paisagem Urbana (CPPU), pertencente à Secretaria Municipal de Habitação (SEHAB), e tendo como projeto-piloto o "Eixo Sé-Arouche". Abarcando um conjunto edificado e não apenas edifícios monumentais, seu objetivo principal era recuperar o conjunto de imóveis e espaços públicos inventariados pelo patrimônio histórico ${ }^{78}$, mediante a desobstrução e recuperação das fachadas encobertas por anúncios, da ordenação dos equipamentos e mobiliários urbanos e de melhorias nos principais espaços públicos da área central (ABRAHÃO, 1999).

Parcialmente implantado, o projeto tinha como estratégia o envolvimento de lojistas, proprietários e moradores, a fim de articular os diferentes interesses e estabelecer as regras de ordenamento dos equipamentos, mobiliários e, principalmente, anúncios. Assim como outras iniciativas do período, o programa se pautou na realização de parcerias público-privadas, contribuindo para a consolidação dessa metodologia de intervenção urbana.

A noção ampliada de patrimônio histórico, por sua vez, esteve claramente presente na realização do "Concurso de Idéias para a Reabilitação do Bairro do Bexiga" em 1989, coordenada pela EMURB, e contando com um amplo processo de debates para a formulação e escolha dos projetos, que envolveu moradores do bairro, técnicos de diversas áreas do conhecimento e as equipes concorrentes. Seguindo os princípios norteadores colocados no edital do concurso, a proposta vencedora elaborou um Plano Integrado de Reabilitação que procurou conciliar preservação e renovação. Indicou as áreas que deveriam ser conservadas e as que poderiam ser transformadas a partir de condições específicas de parcelamento, uso e ocupação do solo, permitindo cessão de coeficiente de aproveitamento adicional e sua transferência para porções do bairro destinadas à renovação.

Também previa a recuperação de equipamentos culturais e espaços públicos, intervenções nos muitos cortiços existentes e produção de habitação de interesse social, procurando manter a população residente. Funcionando como respaldo legal à intenção de garantir a permanência dessa população, foi proposta a indicação dos cortiços como Zona Especial de Interesse Social

\footnotetext{
78 Trata-se do IGEPAC - Inventário Geral do Patrimônio Ambiental, Cultural e Urbano da Cidade de São Paulo, publicado em 1986, pela Secretaria Municipal de Cultura, durante a gestão do Prefeito Mario Covas (1983-1985). Como apontado anteriormente, na década de 1980 o tema do patrimônio histórico ganhou importância em âmbito municipal, especialmente com a criação do CONPRESP em 1985.
} 
(ZEIS), instrumento que estava em discussão no âmbito do Plano Diretor em elaboração na SEMPLA. Para a gestão do processo de reabilitação, o projeto vencedor ainda previa a instalação de um escritório local, o "Espaço Bexiga", com representantes de diversas secretarias e da iniciativa privada, atuando como mediador de conflitos.

O Plano Integrado da proposta vencedora foi transformado em projeto de lei, com vistas a criar a “Área de Preservação e Renovação do Bexiga”, o que não chegou a ser votado na Câmara Municipal. A única iniciativa levada adiante foi o levantamento do patrimônio histórico arquitetônico, realizado pelo DPH para compor o edital do concurso, colocando o bairro em processo de tombamento, o que foi concluído em 2002 (Resolução 22/CONPRESP/2002).

Porém, é importante destacar que no edital do concurso notava-se a preocupação com uma tendência de renovação urbana desordenada que recaía sobre o bairro, uma vez que sua localização seria "muito cobiçada pela especulação imobiliária" (PMSP/EMURB, 1989). Isso justificava a escolha da área para uma ação do poder público, a fim de evitar a expulsão dos moradores tradicionais e de baixa renda - um dos objetivos expressos no edital. Ao articular a preservação do patrimônio histórico, a partir da noção ampliada a que nos referimos, com a intenção de manter o tecido social existente, melhorando as condições de vida da população moradora, as propostas do concurso se alinharam a princípios que vinham norteando experiências estrangeiras de reabilitação de bairros históricos centrais. Em especial, destaca-se a metodologia da Conservação Integrada que surgiu no urbanismo reformador italiano na década de 1960, a qual será abordada no capítulo 3. Parecia enfim, que as diretrizes municipais de preservação se aproximavam daquilo que consta nas Cartas Patrimoniais desde os anos 60, principalmente na Carta de Veneza (1964), Declaração de Amsterdã (1975) e Carta de Lisboa (1995).

Essas iniciativas não chegaram a se articular enquanto uma política para a área central, mas configuraram um conjunto de propostas atentas às especificidades do centro e dos bairros centrais, envolvendo técnicos de diversas secretarias no Núcleo de Planejamento da Administração Regional da Sé. Segundo Sarah Feldman, esse Núcleo "era uma forma de se começar a articular os vários setores para pensar questões específicas locais e formular políticas específicas. (...) durante um ano, reuniu pessoas das várias áreas e conseguiu discutir e esboçar algumas políticas de caráter local” (FELDMAN 1997, apud FRÚGOLI JR., 2000, p.66-67) ${ }^{79}$.

${ }^{79}$ Em entrevista cedida a Frúgoli Jr. 
Voltando aos diagnósticos apresentados no documento "São Paulo: crise e mudança" (PMSP/SEMPLA, 1991a), destaca-se o entendimento da desvalorização imobiliária da área central como um aspecto positivo de suas transformações, reforçado pela estrutura fundiária de lotes pequenos e de difícil remembramento, na medida em que poderia contribuir para a manutenção da população moradora de baixa renda. Esse aspecto foi tido como fundamental para a montagem de uma ação focada na melhoria de cortiços e na produção de habitação social na área, que também integrou as propostas discutidas no Núcleo de Planejamento citado acima.

Buscando garantir o "direito ao centro", a proposta da Prefeitura era manter a população moradora de baixa renda e incentivar maior concentração de habitação social na área, associando política habitacional e política urbana. Ainda que de forma menos explícita, se comparada aos programas desenhados pela gestão Marta Suplicy (2001-2004), entendia-se que o incentivo à habitação social na área central seria um meio para a reabilitação da mesma, bem como para reverter o histórico processo de expulsão das classes populares para as periferias urbanas. Podese perceber essa associação nos trechos citados a seguir:

(...) as vantagens indiretas para a cidade são indiscutíveis, pois se reduz a necessidade de transporte e de ampliação das redes de infra-estrutura e equipamentos sociais e se garante uma mistura de classes sociais e usos no tecido urbano que, embora possa incomodar alguns, é positiva para o bom funcionamento da cidade e para a vida dos cidadãos. (...) $\mathrm{A}$ intervenção busca atingir diferentes objetivos, a nível urbano e habitacional: dar melhor aproveitamento a terrenos subutilizados; criar áreas e equipamentos comunitários de uso não só dos moradores, mas também para a população do entorno, onde há forte concentração de cortiços (...) (BONDUKI, ANDRADE, ROSSETTTO, 1993, p.45)

Reabilitar o centro sem expulsar seus moradores pobres é um desafio que poucas cidades do mundo conseguiram vencer. A Prefeitura tem 15 projetos em áreas de cortiços que constituem iniciativas importantes para a formulação de uma política mais geral. (PMSP/SEHAB, 1992)

A importância dada ao tratamento dos cortiços e à construção de moradia social na área central também permeou as propostas de intervenção no centro discutidas durante a gestão Marta, cujos documentos oficiais - sistematizados no capítulo anterior - explicitaram o objetivo de garantir a permanência da população de baixa renda, melhorando suas condições de vida e associando incentivo à produção habitacional e reabilitação urbana. Tal intenção ganharia força com a aprovação do Estatuto da Cidade em 2001, gerando grande expectativa com relação aos instrumentos urbanísticos regulamentados, como veremos no capítulo 3. Programas, formas de atuação e mecanismos legais propostos ou implementados na administração Erundina foram retomados a partir de 2001 para a montagem do Programa Morar no Centro, que integrou o financiamento do BID aprovado em 2004, como vimos.

Entre os programas habitacionais da gestão Erundina, destaca-se o "Programa Executivo de Cortiços", que contou com duas modalidades de atuação - produção de novas unidades de 
habitação social e recuperação de cortiços existentes - e teve projetos continuados pela gestão Marta Suplicy, como já destacado no capítulo 1. O programa envolveu a criação da "Comissão de Intervenção e Recuperação em Cortiços" (CIRC) para coordenar as ações, fiscalizar os imóveis, fazer a mediação entre proprietários, moradores e intermediários, e emitir certificados de habitação coletiva para cobrança de tarifas sociais, mais acessíveis para a população.

Também se destacam as discussões desse período em torno da formulação de um respaldo legal para a efetivação dos programas habitacionais, principalmente em relação a 3 conjuntos normativos. O primeiro foi a definição de parâmetros de habitabilidade mínima das habitações coletivas precárias (cortiços), instituídos pela Lei Moura (Lei Municipal 10.928/1991) ${ }^{80}$ para serem utilizados nas intervenções e fiscalizações. O segundo foi a conceituação de Habitação de Interesse Social (HIS) e o estabelecimento de parâmetros para sua produção, incluindo a flexibilização de índices urbanísticos e a isenção do pagamento de contrapartidas à Prefeitura (outorga onerosa), o que se deu pelo Decreto de HIS (Decreto Municipal 31.601/1992).

Por fim, como terceiro conjunto, as propostas do Plano Diretor de 1991 reforçariam os dispositivos do Decreto de HIS, caso o plano não tivesse sido vetado na Câmara Municipal. Para o centro, sua principal proposta era a delimitação de ZEIS de tipo 4 em perímetros com concentração de cortiços, localizados na área central, onde ocorreriam as ações do Programa de Cortiços. Indicava-se que nessas áreas deveriam ser realizadas "operações de interesse social", prevendo a participação do setor privado na produção de habitação social e permitindo a utilização de índices acima do coeficiente de aproveitamento único sem pagamento da outorga onerosa $^{81}$. Também previa a aplicação do instrumento da urbanização e edificação compulsórias, como determinado na Constituição Federal de 1988, entendendo-o como meio para forçar a entrada no mercado de grande quantidade de terreno e gerar um rebaixamento de preço, possibilitando uma diminuição no preço da habitação na cidade (PMSP/SEMPLA, 1991b).

Porém, nas gestões municipais seguintes, os projetos habitacionais foram paralisados, gerando reações dos movimentos de moradia no centro e explicitando as disputas políticas por projetos. Diante da ausência de política habitacional e defendendo o direito à moradia em locais próximos do trabalho, de equipamentos e serviços públicos, os movimentos passaram a ocupar edifícios

\footnotetext{
${ }^{80}$ Esses parâmetros foram regulamentados apenas pelo decreto municipal 33.189/93, já na gestão de Paulo Maluf. A definição de habitação coletiva precária (cortiço) é dada pela Lei Moura da seguinte forma: "define-se cortiço como a unidade usada como moradia coletiva multifamiliar, apresentando, total ou parcialmente, as seguintes características: a) constituída por uma ou mais edificações construídas em lote urbano; b) subdividida em vários cômodos alugados, subalugados ou cedidos a qualquer título; c) várias funções exercidas no mesmo cômodo; d) acesso e uso comum dos espaços não edificados e instalações sanitárias; e) circulação e infra-estrutura, no geral precárias; f) superlotação de pessoas” (LM 10.928/91, art. $1^{\circ}$ ).

$81 \mathrm{O}$ plano havia proposto a utilização de coeficiente único igual a 1 para toda cidade, acima do qual deveria ser paga uma taxa à prefeitura (outorga onerosa do direito de construir).
} 
vazios no centro, como forma de pressão sobre os poderes públicos para a efetivação de soluções, em especial aos moradores de cortiços. Como apontado no capítulo 1, uma das respostas dadas às reivindicações dos movimentos foi a montagem do Programa de Atuação em Cortiços da CDHU em 1998, financiado pelo BID (PAC-BID). No entanto, esse programa teve estreita relação com as iniciativas do Governo do Estado de revitalização com enfoque no uso cultural, pressupondo a necessidade de eliminar os cortiços existentes, sem necessariamente manter sua população moradora na área de intervenção.

As propostas do Governo do Estado, por sua vez, contribuíram para o fortalecimento da temática da degradação do centro e de sua revitalização, através de uma contínua canalização de esforços e recursos públicos na região, em especial no bairro da Luz. Como já mencionado, tal canalização vem ocorrendo desde a década de 1980 com o "Projeto Luz Cultural", seguindo na década 1990 com os projetos "ancora" integrantes do "Pólo Luz" ${ }^{82}$ e com a montagem do Programa Monumenta/Luz; esse último com recursos do BID e coordenado pelo Ministério da Cultura, prevendo investimentos privados para recuperação de edifícios de valor histórico.

\subsubsection{CONSOLIDAÇÃO DAS IDÉIAS DE DEGRADAÇÃO E REVITALIZAÇÃO URBANA}

Ao mesmo tempo em que muitas das iniciativas da gestão Erundina propunham uma ocupação democrática do centro, buscando garantir a permanência da população de baixa renda, a década de 1990 também foi marcada pela consagração de práticas urbanísticas de cunho neoliberal, pautadas na flexibilização da legislação urbanística e nas parcerias público-privadas. Em meio a disputas por diferentes projetos de intervenção na área central, tornava-se claro que revitalizar o centro, segundo o pensamento dominante, significava retomar a dinâmica econômica do mesmo, atraindo empresas, usuários e moradores de maior poder aquisitivo, revalorizando os imóveis e alterando usos - consolidava-se um modelo de revitalização.

As exigências de ajustes fiscais das contas municipais, frente à crise econômica iniciada na década de 1980, com aumento da dívida externa e diminuição dos repasses federais, contribuíam para a consolidação desse modelo. Desde então, como veremos no capítulo seguinte, tais ajustes e práticas têm sido difundidos pelos organismos multilaterais, inclusive pelo BID, banco financiador do Programa Ação Centro. Embora as propostas da segunda metade da década apresentem de forma mais explícita os pressupostos da flexibilização e das parcerias - aplicado

82 Integram o "Pólo Luz" as emblemáticas obras de restauro e adaptação de usos dos edifícios da Estação Júlio Prestes, Pinacoteca do Estado, Estação da Luz, antigo DOPS, entre outros de menor porte. 
não apenas no centro - pode-se notar algum alinhamento a eles já em seus primeiros anos, durante a administração Erundina.

Para essa consolidação, foi primordial a atuação da Associação Viva o Centro (AVC), que reuniu empresários, comerciantes e moradores-proprietários preocupados com os problemas da região, em especial a perda de atividades econômicas, a grande desvalorização imobiliária e a presença de comércio e usos populares ou informais. Percebe-se pela análise de documentos oficiais, que as gestões Paulo Maluf (1993-1996) e Celso Pitta (1997-2000) alinharam-se ao pensamento da AVC, como dito anteriormente, permitindo o fortalecimento dessa última, enquanto entidade proponente e difusora da idéia de revitalização do centro, defendendo a reversão da degradação do mesmo e pautando as agendas do poder público. Sua maior preocupação era (e ainda parece ser) conter uma "segunda onda" de abandono do centro por parte de empresas do chamado "terciário avançado" 83 , frente ao desenvolvimento de outras localizações mais atrativas - "novas centralidades terciárias" nas regiões da Faria Lima e da Berrini/Nações Unidas (LABHAB/LILP/CAIXA, 2006).

A AVC também contribuiu para a consolidação da idéia de degradação da área central. Como visto no capítulo 1, seus diversos seminários e workshops, além de difundir a necessidade de revitalização, chamavam a atenção para os fenômenos considerados parte da degradação da área. Seus periódicos e publicações ${ }^{84}$ também são um dos meios que mais difundem a idéia da degradação, muitas vezes de forma indireta, através da apresentação de sugestões para a revitalização do centro (pressupondo que ele apresenta problemas, portanto). Um de seus principais apontamentos mostra a contradição de suas afirmações. Por um lado, destaca ser inadequado "o uso da palavra declínio" para designar a atual condição do centro, uma vez que ele apresenta grande dinâmica social e de atividades econômicas, mesmo com a "descentralização funcional" e o surgimento de inúmeros centros de bairro. Por outro, afirma em diversos textos que o centro está "enfraquecido", "perdendo sua substância” e entrando em "processo de declínio"; ou ainda, que apresenta "usos inadequados e abusivos" e "ociosidade da infraestrutura" existente - entendidos como disfunções (VIVA O CENTRO, 1993). O trecho abaixo é exemplar do entendimento da Associação sobre a degradação do centro.

\footnotetext{
83 Empresas com atuação global como as de consultoria empresarial, informática, consultoria jurídica empresarial, marketing, comunicações, etc. Classificação segundo Castells (1998) e Sassen (1998), citados em Ferreira (2007).

84 Destacamos os seguintes materiais: Documento 1 de 1993, que apresenta os objetivos e intenções da Associação, bem como um diagnóstico do centro; Camelôs de 1994, relatório do seminário organizado pela Viva o Centro para discutir o problema do comércio ambulante e buscar soluções, já abordado no capítulo 1 desta dissertação; e os textos publicados na Revista URBS n.23 de out/nov de 2001, em ocasião da comemoração dos 10 anos da Associação Viva o Centro.
} 
O Centro é um organismo pleno de vitalidade mas, como que afetado por estranha doença, parece converter energia em disfunção, vitalidade em deseconomia, efervescência humana em conflito. Assim, o Centro de São Paulo pode ser entendido como um organismo vital que, a partir de um ponto de sua história, passa a evoluir num sentido que resulta bom para alguns e ruim para outros - a maioria, talvez. Monumental e belo, mas mal-cuidado. Economicamente exuberante, mas perdendo empresas. Com um comércio poderoso e diversificado, mas sufocado por camelôs. Com duas linhas de metrô, mas sem espaço nas calçadas. Repleto de opções culturais e de lazer, mas freqüentável só até o começo da noite. Residencial, sim, mas com perda acelerada de moradores. (...) O Centro não está decadente. Ele simplesmente se desenvolve numa direção errada. Não necessita ser revitalizado, porque ele é extremamente vital. Deve, isto sim, ser requalificado - reordenado, refuncionalizado. (BARRETO, 1997, grifos nossos)

No que consiste esse desenvolvimento em "direção errada"? Quais os processos que acarretam os fenômenos apontados no artigo? Em geral, as Revistas URBS publicadas pela AVC enfocam diversos fenômenos presentes na área central, entendendo-os como causa da fuga de atividades produtivas, de sua relocalização em outras regiões da cidade, já que no centro "a miséria, as aglomerações de camelôs e a falta de zelo e conservação ajudam a criar um ambiente depressivo e agressivo". Para a AVC, uma crescente sensação de insegurança, somada à perda da identidade e da beleza, é decorrência de um envelhecimento natural do centro e da presença de comércios e serviços populares e informais, assim como das camadas sociais para as quais estes serviços são destinados.

Também é notável a vinculação da deterioração do centro com a chamada reestruturação produtiva e o fortalecimento, no final dos anos 80, de "novas centralidades terciárias globais", enquanto o "centro já apresentava fortes sinais de desgaste e desprestígio" e passava por acentuada desvalorização simbólica e perda de identidade.

Diga-se, desde logo, que à crise do Centro corresponde uma mudança estrutural na cidade (...). O que ocorre é uma reestruturação profunda do aparato produtivo da cidade, a transição do modelo industrial-fordista para o terciário, com um rastro de incertezas, desagregação social e insegurança. (...) a crise de obsolescência do Centro se manifesta um pouco antes e atinge um paroxismo no final da década anterior [1980], quando os paulistanos chegaram a perder a noção da cidade. (...) A cidade estava descentrada, e também seus moradores. A recessão dos anos 80 e a inflação galopante que se seguiu abalaram o núcleo central das pessoas, o seu self e auto-imagem, e da própria cidade. (VIVA O CENTRO, 2001a, grifos nossos)

Ou seja, a "crise" do centro - obsolescência, desvalorização e perda de valor simbólico - é colocada como decorrência da transição do modelo econômico industrial para o terciário, em que se desenvolveram outras regiões da cidade mais conectadas com os fluxos "globais" da economia mundial. $\mathrm{O}$ centro estaria obsoleto frente às necessidades desse novo modelo econômico, em que modernas empresas demandam novos padrões imobiliários que o centro não é capaz de oferecer.

Centros regionais se multiplicaram pelos bairros e surgiram as novas centralidades representativas do emergente perfil econômico e funcional - a metrópole terciária inserida nas redes mundiais - abrigando sedes de empresas multinacionais e bancos de investimento, shopping centers, flats e, mais recentemente, firmas de publicidade e de 
internet. No Centro, isolados do resto do organismo metropolitano e semi-esquecidos, ficaram os testemunhos arquitetônicos, as paisagens tradicionais, os espaços verdadeiramente públicos e a democracia das ruas. A cidade começa a tornar-se um corpo sem cabeça, sem consciência de si, sem memória. Este é o descentramento. (VIVA O CENTRO 2001a, grifos nossos)

O entendimento apresentado pela AVC é que nesse contexto de terceirização da economia "globalização" - o centro tradicional teria perdido atratividade para instalação de empresas modernas do chamado "terciário avançado". O desenvolvimento dessas atividades, típicas da nova fase "global" da economia, representaria a entrada de São Paulo na rede de "cidadesglobais", tendo como manifestação maior a centralidade da Berrini/Nações Unidas. Assim, por não estar apto a abrigar essas atividades, apresentando usos inadequados e incompatíveis ao seu desenvolvimento, o centro teria entrado em "declínio".

Dois contrapontos, no entanto, são suficientes para mostrar a fragilidade desse entendimento. Primeiro, deve-se atentar para o fato de que a metrópole de São Paulo sempre teve predominância dos setores terciários, como qualquer grande aglomeração urbana (FERREIRA, $2007)^{85}$. A concentração de comércios e serviços no centro é considerável se atentarmos para os indicadores de área construída, número de estabelecimentos e oferta de empregos. Silva (2001) mostra que, de acordo com dados da TPCL trabalhos por SEMPLA/DEPLANO ${ }^{86}$, entre $1991 \mathrm{e}$ 2000 houve aumento de $7,3 \%$ da área construída vertical ocupada por atividades do setor terciário na área central, mantendo-se importante apesar de certa queda de sua participação no total do município (de 54,64\% para 45,62 no período). Em estudo contratado pela EMURB em 2002 é possível constatar que houve também aumento do emprego formal nos setores de “serviços empresarias" (de 4,8\% para 7,1\%, no período 1992-2000) e de "turismo e hotelaria", apesar de sua queda na participação relativa ao total do município (CEBRAP/CEM, 2002).

O segundo contraponto está na constatação de alguns estudos que mostram que o desenvolvimento das empresas do "terciário avançado" ainda está distante de consolidar São Paulo como "cidade-global". Apesar de certo crescimento dessa atividade, Ferreira (2007) destaca que seu padrão de localização é muito mais o espraiamento por diversas áreas da cidade do que uma concentração na "nova centralidade terciária" da Berrini/Nações Unidas. Também se identifica que as porções sul e oeste da área central - distrito da Consolação e os próprios Centros Velho e Novo - contam com certa concentração de modernas empresas do setor

\footnotetext{
85 Além de mostrar essa histórica predominância de comércios e serviços, Ferreira (2007) aponta que mais do que queda no nível de emprego e ocupação industrial, e aumento no nível de emprego em serviços, São Paulo tem apresentado taxas altíssimas de crescimento do trabalho informal (130\% entre 1985 e 2000) e de desemprego (de 8,2\% para 17\% entre 1988 e 1998). Nesse sentido não se comprova a propalada inversão terciária, mas sim o enorme aumento na precarização das relações de trabalho.

86 Trata-se de dados do Cadastro Territorial e Predial de Conservação e Limpeza, trabalhados pelo Departamento de planejamento da SEMPLA.
} 
terciário, como as de consultoria jurídica, do setor financeiro e de gestão empresarial (MALTA, KAZUO, ROLNIK, 2004).

Não pretendemos negar as mudanças em curso, tanto na esfera econômica como na organização espacial da cidade, que se refletem na produção e apropriação do espaço central, colocando-o em concorrência com outras centralidades pela atração de investimentos privados e públicos. Apenas levantamos elementos ausentes nas interpretações expostas a fim de melhor compreender esses processos. Nesse caso, a AVC se pauta na propalada idéia de "globalização" para explicar a degradação - popularização, obsolescência e desvalorização simbólica do centro - e não aborda as disputas políticas na produção do espaço urbano, escondendo interesses econômicos e políticos inerentes às transformações da área central, e construindo lacunas em seus discursos.

Ao vincular a "crise" do centro com sua popularização - presença de camelôs, catadores de materiais recicláveis, camadas de baixa renda, sensação de insegurança - e obsolescência fundiária e imobiliária, usos inadequados, desprestígio, falta de acessibilidade, de zelo - se formula e difunde um discurso ideológico das transformações do espaço central - deterioração entendida como pobreza, feiúra e inadequação. Essa seria, segundo a AVC, a razão para as empresas modernas preferirem sair do centro e dos bairros centrais rumo às áreas "globalizadas" da cidade, da mesma forma que as classes de alta renda, os comércios e serviços voltados a elas e setores do mercado imobiliário. Nesse sentido, também se naturaliza o processo em curso, como se popularização e obsolescência fossem decorrências de um "envelhecimento" natural do centro diante da "globalização", do crescimento urbano e da produção de novas áreas (VILLAÇA, 2001).

Foi a partir desse entendimento da deterioração que a AVC passou a pautar as iniciativas públicas para revitalização do centro (FRÚGOLI JR., 2000) - como já destacamos no capítulo 1 - e as leituras oficiais sobre os fenômenos e transformações em curso. Percebe-se que a maioria dos documentos do poder público elaborados na década de 1990 apresentou diagnósticos enfocados nos fenômenos da desvalorização imobiliária e estagnação econômica da área central, entendendo a deterioração como causa.

Assim como nos textos e publicações da Associação, muitos dos documentos oficiais do período - PROCENTRO, Cartilha da Área Central (Operação Urbana Centro), Pólo Luz - destacaram como principal problema do centro o movimento de saída das empresas modernas e de alta tecnologia, desde os anos 1970. Esse movimento, por sua vez, estaria ocorrendo devido à deterioração ambiental, à restrição ao acesso de veículos - com destaque para a implantação dos 
calçadões $^{87}$ na década de 1970 - e à obsolescência do estoque imobiliário, fazendo com as empresas procurassem outras localizações.

Os diagnósticos apresentados tinham como base a idéia de um "processo de declínio", em que pesa o fato das edificações existentes não possuírem o porte e a qualidade necessários para o atendimento das demandas das empresas que se quer manter ou atrair para o centro. Mais ainda, as causas da saída de empresas seriam: deterioração ambiental e paisagista, deficiência da segurança pessoal e patrimonial, existência de "abusos de usos" - comércio ambulante e sem tetos nas ruas - e a fragilidade funcional, ou seja, atividades consideradas inadequadas ao papel do centro e incompatíveis com empresas de alta tecnologia (SÃO PAULO/DIÁRIO OFICIAL, 1993).

Como apontado no capítulo 1, o PROCENTRO foi o ponto de partida das negociações que visavam à obtenção de financiamento do BID para a revitalização do centro, ainda na gestão Pitta. Entendendo o declínio do centro como descrito acima, seu objetivo principal era reverter o processo de degradação, em especial da área correspondente aos distritos Sé e República, através da melhoria da acessibilidade por automóveis e da diminuição do tráfego de passagem; da melhoria do ambiente urbano, envolvendo recuperação de fachadas, calçadas, espaços públicos e limpeza; do aumento da segurança; e da revisão da legislação urbanística. Essa última, vista como essencial à realização dos empreendimentos privados necessários para a revitalização do centro.

Para a modernização das edificações existentes e a construção de novas (...) é necessário muito investimento por parte, principalmente, da iniciativa privada. Mas para que isso ocorra é necessário que os investidores acreditem no processo de requalificação e revalorização do Centro e que posturas do Código de Obras, da Lei de Zoneamento e dos próprios critérios de tombamento, muito incidente na área, sejam revistos e atualizados. (SÃO PAULO/DIÁRIO OFICIAL, 1993, p.6, grifos nossos).

Dessa forma, além de prever melhorias em espaços públicos, o PROCENTRO incluiu a proposta de uma operação urbana, a fim de flexibilizar índices e parâmetros urbanísticos, cedendo benefícios à iniciativa privada como forma de atrair seu interesse de investir no centro, atendendo uma suposta demanda "reprimida" do mercado imobiliário. Tal proposta se efetivou em 1997, com a regulamentação da Operação Urbana Centro (Lei Municipal 12.349/1997), substituindo a Operação Urbana Anhangabaú (Lei Municipal 11.090/1991) implementada durante a gestão Erundina.

\footnotetext{
87 A Viva o Centro sempre ressaltou a dificuldade de acesso ao centro por automóveis como um dos principais fatores para sua estagnação econômica, uma vez que influenciaria diretamente nos interesses de localização das empresas, e nesse sentido a Associação tem se pronunciado a favor da abertura de alguns calçadões para o tráfego de veículos. Vale lembrar que entre as ações no Programa Ação Centro, objeto desta pesquisa de mestrado, constou o projeto "Novo Calçadão" que envolvia a abertura para o tráfego de veículos. A administração municipal Serra/Kassab (2005-2008) tem realizado desde 2005 a abertura de alguns calçadões, como destacamos no capítulo 1. Ver VIVA O CENTRO, Associação. Proposta de Revisão dos Calçadões do Centro. São Paulo: AVC, 2005.
} 
A operação Urbana Anhangabaú foi criada sob a justificativa de arrecadar recursos para a finalização das obras de reurbanização do Vale do Anhangabaú, o que pressupunha a atração de investimentos privados. No início do governo Erundina, as obras do vale estavam paralisadas devido à falta de dinheiro no caixa da Prefeitura, herança da enorme dívida deixada pela administração Jânio - agravando a crise das finanças municipais iniciadas na década de 1980. Com um prazo de vigência de 3 anos (1991-1993), a operação criada pelo governo petista visava também à realização de um Programa de Obras de melhoria de espaços públicos, implantação e manutenção de calçadões, entre outros.

Para a realização dessas obras, foi estabelecido um estoque de potencial construtivo adicional para a área da operação (entorno do vale) e flexibilizada a legislação urbanística e edilícia, envolvendo a utilização de coeficientes de aproveitamento acima do permitido pelo zoneamento, mediante outorga onerosa paga a prefeitura. Também foi permitida a transferência de potencial construtivo dos imóveis de valor histórico, a fim de incentivar a preservação dos mesmos ${ }^{88}$. Seriam formas de atrair o interesse de investidores para a área.

No entanto, como aponta José Eduardo Lefèvre (1997), então coordenador de operações urbanas da EMURB, “a compra de potencial construtivo não era objeto de desejo. (...) poucas pessoas quiseram comprar potencial construtivo na área central". Segundo o autor, pelo fato do centro já possuir um dos maiores coeficientes de aproveitamento da cidade, com altas taxas de área construída real e conseqüentes limites para o aproveitamento dos lotes, fez com que não houvesse interesse do capital privado em realizar empreendimentos imobiliários na área. $\mathrm{O}$ mercado privado teria considerado, então, que os incentivos oferecidos pela operação eram insuficientes. Além disso, a finalização das obras do vale não utilizou recursos da operação, na medida em que a primeira ocorreu antes da aprovação da lei que a regulamentou a segunda.

Sua sucessora Operação Urbana Centro (ainda vigente) propôs as mesmas estratégias para atrair o interesse de investidores privados e alcançar a revitalização do centro. Porém não listou as obras públicas que seriam realizadas com os recursos arrecadados, ampliou sua área de abrangência para os distritos Sé e República e porção do Brás (zona cerealista) e alterou alguns mecanismos de atração de investimentos. Nesse último caso, previa maiores incentivos a determinados usos e remembramento de lotes, chegando a coeficientes de aproveitamento igual a

\footnotetext{
${ }^{88}$ Em paralelo à criação da Operação Urbana foi aberto processo de tombamento de um conjunto de 293 edificações e 9 logradouros públicos, na área do entorno do vale, abrangendo também a porção do centro novo até a Praça da República (Resolução 37/CONPRESP/1992). Vale notar que a gestão Erundina chegou a propor outra operação urbana na região do Parque Dom Pedro II e Pari, o que reforçaria as atenções dadas à área com a transferência da sede da prefeitura para o Palácio das Indústrias e a intenção de executar projeto de recuperação do parque como um todo, como apontado anteriormente.
} 
6 para uso residencial e de escritórios, e 12 para hotéis, ou ainda, excluindo da área computável os usos de lazer, turismo e cultura, e de estacionamento vinculado à habitação ${ }^{89}$ (PMSP/SEHAB/PROCENTRO, 1997b).

Ainda como integrante das propostas do PROCENTRO, foi indicada a necessidade de recuperação de fachadas com participação da iniciativa privada, como forma de melhorar a paisagem urbana do centro. Essa proposta também se efetivou em 1997, em conjunto com a Operação Centro, através da aprovação da Lei de Fachadas (Lei Municipal 12.350/1997 e Decreto Municipal 37.302/1998). O mecanismo criado previa a isenção do pagamento de IPTU num prazo de 10 anos para imóvel tombado dentro do perímetro do PROCENTRO, desde que o mesmo fosse restaurado. Seu princípio norteador foi gerar uma compensação aos proprietários frente aos limites impostos pelo instituto do tombamento, da mesma forma que a lei proposta na década de 1980.

No entanto, até 2005 apenas 14 dos 60 pedidos protocolados foram aprovados - num conjunto de cerca de 400 imóveis tombados na área - sendo a maioria para instituições financeiras ou comerciais, com "proprietários de imóveis administrativamente alto suficientes, não atingindo imóveis ocupados por população de menor renda e atividades 'mais simples"' (LABHAB/LILP/CAIXA, 2006, p.91). Ou ainda, beneficiando apenas proprietários com capacidade de investimento, uma vez que a lei não previa financiamentos para as obras de restauro. Da mesma forma, as solicitações para utilização de mecanismos da Operação Urbana Centro enfocaram a transferência do potencial construtivo para outras regiões da cidade, refletindo o interesse do mercado pelas áreas a sudoeste da cidade (LABHAB/LILP/CAIXA, 2006).

De maneira geral, pode-se afirmar que os instrumentos urbanísticos aplicados até o momento no centro, visando sua revitalização por meio de atração de investimentos privados, arrecadação de recursos oriundos de contrapartidas financeiras ou recuperação do patrimônio histórico com participação da iniciativa privada, não obtiveram resultados satisfatórios. Foram poucos os pedidos aprovados e as operações imobiliárias efetivamente realizadas, como se pode perceber nos balanços já realizados por técnicos do próprio poder público ${ }^{90}$ e por pesquisas acadêmicas

\footnotetext{
${ }^{89}$ A área computável é um dos fatores do cálculo do coeficiente de aproveitamento utilizado pelo empreendimento. Em seus três primeiros anos de vigência, a lei da Operação Centro ainda permitia a utilização de coeficiente 18 para hotéis e isenção da outorga onerosa para uso habitacional, serviços de escritório e negócios.

${ }^{90}$ Em 2001 foram montados grupos de trabalho envolvendo técnicos do PROCENTRO, SEHAB, DPH, Secretaria de Finanças, Subprefeitura Sé, Secretaria de Negócios Jurídicos, entre outros, a fim de discutir os entraves da Lei de Fachadas e da Operação Urbana Centro. Para a primeira chegou-se a montar uma minuta de lei com a revisão proposta pelo grupo, no entanto, não foi encaminhado projeto à Câmara Municipal.
} 
recentes (LABHAB/LILP/CAIXA, 2006). Mesmo com consideráveis investimentos públicos realizados, em âmbito municipal e estadual, buscando melhorar a paisagem e o ambiente urbano da área central, para que "investidores acreditem no processo de requalificação e revalorização" (SÃO PAULO/DIÁRIO OFICIAL, 1993, p.6), os instrumentos aplicados não têm gerado o desejado efeito de atração. Como aponta um incorporador,

(..) não adianta dar incentivos pra iniciativa privada, se não mudar aspectos da realidade. Não adianta lançar um empreendimento que não vai vender. Não é "vai mudar". Tem que ir lá e mudar mesmo. (CURIAT'TI, 2006, apud TSUKUMO, 2007, p.185)

A despeito da análise de resultados, o que vemos é a consolidação de um modelo de intervenção urbana de cunho neoliberal, pautado na atração de investimentos privados mediante flexibilização das legislações urbanísticas existentes e parcerias do poder público com setores do capital. Nesse período, o discurso do poder público esteve claramente vinculado aos alinhamentos ideológicos da Associação Viva o Centro", tecendo aproximações com as teorizações sobre as "cidadesglobais" e com explicações pautadas numa idéia comum de "globalização" para o entendimento das transformações no centro.

Propalou-se a idéia de que o centro havia se tornado esvaziado, desvalorizado e sem identidade, em decorrência de sua degradação, obsolescência, insegurança, falta de acessibilidade e manutenção. Ou seja, comércios e serviços sofisticados, classes de alta e média renda, setores do mercado imobiliário, entre outros usos e atividades de alto padrão, estariam saindo do centro devido sua degradação - entenda-se, sua ocupação por usos populares e classes de baixa renda, a sujeira e não conservação de espaços públicos e edifícios, as dificuldades em acessá-lo por automóvel e a existência de um estoque imobiliário inadequado às demandas econômicas contemporâneas ("globais"). Isso nos leva a concluir que os diagnósticos e interpretações propalados tinham como pressuposto um centro anteriormente belo, limpo e seguro, com atividades e usos destinados às camadas de rendas média e alta, em que tais grupos o ocupavam de forma homogênea.

Seria necessário, portanto, revitalizá-lo através de uma retomada de sua dinâmica econômica, atraindo empresas, usuários e moradores de maior poder aquisitivo, revalorizando os imóveis, alterando usos e recuperando seu estatuto de "espaço emblemático da cidade, espaço onde a cidade encontra sua identidade" (SÃO PAULO/DIÁRIO OFICIAL, 1993, p.2). Parece-nos que os discursos em defesa da revitalização do centro se constituíram numa importante ferramenta

\footnotetext{
91 A própria Viva o Centro mostra sua influência sobre as ações do poder público, voltadas à revitalização do centro quando se remete à criação do Procentro, a implantação da Operação Urbana Centro, da Lei de Fachadas e diversos outros projetos e programas (Pólo Luz, Praça do Patriarca, Mosteiro de São Bento). Os documentos oficiais do poder público também afirmam a participação da Associação na elaboração dos diagnósticos e propostas. Ver Revista URBS n. 23 de out/nov de 2001.
} 
destinada a manter o poder simbólico do espaço central, já que as camadas de alta renda não poderiam abandoná-lo totalmente, uma vez que se trata do espaço de representação de seu domínio econômico e político.

\subsection{IDEOLOGIA DA DEGRADAÇÃO}

Por que as camadas hegemônicas e o mercado imobiliário afirmam sair do centro devido sua popularização se, na virada do século XIX, “obstáculos” similares foram vencidos para que elas pudessem torná-lo seu espaço privilegiado, mantendo seu domínio econômico e social? Porque as "novas" atividades terciárias resolveram se instalar fora do centro alegando sua "obsolescência" se, ao longo de todo o século XX, a área foi constantemente adaptada e renovada para atender as necessidades econômicas e os padrões imobiliários de cada período?

O destaque dado à desvalorização simbólica que tem afetado o centro - cidade como um "corpo sem cabeça, sem consciência de si" em que os moradores (leia-se as elites) tiveram "seu self e auto-imagem" abalados - reforça a formulação de uma leitura ideológica de suas transformações recentes. Como se o centro tivesse sido um espaço apropriado por todos os habitantes da cidade, de representação da história de todos os cidadãos paulistanos, e que agora perde sua identidade. Porém, desde a virada do século XIX e em meio a disputas, o centro foi um espaço produzido para a representação do poder e domínio das camadas de alta renda (VILLAÇA, 2001), através das diversas ações do Estado e do mercado imobiliário. Dessa forma, nos parece que essa desvalorização é, na verdade, a perda das bases simbólicas do espaço central, do espaço de representação do poder dessas classes.

O que de fato ocorreu no centro e nos bairros do seu entorno foi um processo de abandono pelas camadas hegemônicas de alta renda e, conseqüentemente, pelo Estado e pelo mercado imobiliário. O "caminhamento" dos bairros residenciais dessas classes atrai para perto de si as atividades de comércios e serviços, arrastando dessa forma o próprio centro em sua direção. Segundo Villaça (2001), o controle das condições do deslocamento humano - tempo e energia gastos - é a principal força que atua sobre a produção do espaço urbano, sendo as classes hegemônicas as que têm maiores possibilidades de exercer esse controle, através do domínio do Estado e do mercado. Assim, o sentido do "caminhamento" de seus bairros deverá ser o mesmo sentido da expansão do centro, garantindo as melhores condições de deslocamento entre os primeiros e o segundo, produzindo "localizações" privilegiadas dentro da aglomeração urbana. 
Sendo produzido, fruto de "trabalho social", o espaço urbano é entendido como "produto social". Enquanto tal, envolve agentes mediados por disputas e conflitos de interesse, em que grupos hegemônicos - de maior renda - controlam os meios da produção social do espaço. $\mathrm{Ou}$ ainda, como diria Harvey (1982), a produção e apropriação do espaço urbano estão mediadas pelas relações entre capital e trabalho, ou seja, pelas disputas inerentes ao desenvolvimento do capitalismo industrial. Se o controle sobre as condições de deslocamento humano é o principal fator dessa produção do espaço - numa disputa por "localizações" - então o centro será o espaço mais disputado pelos grupos sociais, o "ponto em que está cristalizada a maior quantidade de trabalho socialmente necessário despendido na produção da aglomeração e pela aglomeração" (VILLAÇA, 2001, p.241).

Esse processo de disputa pelo controle dos meios da produção social do espaço e das condições de deslocamento - "caminhamento" dos bairros das elites e expansão/abandono do centro - não é algo novo, apesar de algumas características peculiares mais recentes, especialmente a constituição de um novo tipo de centro atomizado e fragmentado, como apontado por Villaça (2001). Um processo que vem se desenrolando desde a virada do século XIX para o XX, quando foram loteados os primeiros bairros residenciais de alta renda a oeste e sudoeste - Campos Elíseos, Vila Buarque, Higienópolis - renegando as imediações do triângulo como local de moradia (FELDMAN, 2004). Foi o primeiro movimento de abandono. As ações higienistas e sanitaristas do Estado - proibição e remoção de cortiços - bem como os planos urbanísticos do começo do século XX - Plano Bouvard para o Anhangabaú e para a urbanização da várzea do Tamanduateí - foram determinantes para a formação da idéia de um centro exclusivo das camadas de alta renda.

O expurgo das camadas populares, principalmente de suas moradias, do perímetro urbano - o centro - significou o domínio dos grupos de maior renda sobre o espaço, a intenção das elites cafeeira e industrial em adequar a cidade (sua imagem e produção) às suas necessidades de reprodução. Intervenções urbanas que explicitavam os interesses políticos e econômicos desses grupos hegemônicos e liberavam o espaço central para um processo de valorização dos terrenos, constituindo as "bases legais para um mercado imobiliário de corte capitalista" (MARICATO, 2001, p.17), muito pautado na especulação. O centro (das elites) se tornava o espaço privilegiado para acumulação de capital através da produção imobiliária intensiva - vertical e adensada (SOUZA, 1994; SOMEKH, 1997).

Não foi por seu 'envelhecimento' que o centro principal foi abandonado. Se conviesse às burguesias continuar a usá-lo, elas o teriam renovado e aprimorado, como aliás, já haviam feito no passado, em inúmeros casos. (...) as burguesias continuamente renovaram o centro, em especial na direção de expansão que lhes interessava. (...) Essa modernização, 
patrocinada pelo Estado, era indispensável para o pleno florescimento de grandes empreendimentos imobiliários. Tais obras mostram que as elites aprimoraram os centros principais quando precisaram permanecer neles. (VILLAÇA, 2001, p.279)

Na seqüência, o centro das elites - seu local de trabalho, compra, serviços, lazer e atividades culturais - começou a se deslocar para o outro lado do Anhangabaú, formando o chamado Centro Novo. Foi o segundo movimento de abandono, consolidado no final dos anos $30 \mathrm{com}$ as obras viárias do Plano de Avenidas, permitindo que o triângulo histórico - Centro Velho passasse a ser ocupado por camadas de mais baixa renda. Ao consolidar a expansão de seus bairros na direção sudoeste - Avenida Paulista, bairros jardins - as elites "puxaram o seu centro" para perto de si, deixando o espaço do triângulo definitivamente para trás e cada vez mais associado ao centro do Brás a leste. Nos anos 50 e 60, quando esses bairros de alta renda atingiram áreas ainda mais longínquas - Marginal Pinheiros, Morumbi - as atividades econômicas voltadas para essa classe passaram a se localizar em outras regiões da cidade, nos arredores da Rua Augusta, Avenidas Paulista, Faria Lima ${ }^{92}$ e chegando até a avenida Luis Carlos Berrini, regiões do Itaim-Bibi e da Vila Olímpia.

Esse deslocamento espacial representa uma lógica de operacionalização da produção do espaço urbano que vem ocorrendo desde a formação dos primeiros bairros de alta renda. Essas classes buscaram um isolamento do centro - que no final do século XIX era marcado pela mistura de usos e classes sociais (ROLNIK, 1999; CALDEIRA, 2000) - criando seus bairros exclusivos e privilegiados, ao mesmo tempo em que produziram um espaço central, de concentração de comércios e serviços sofisticados, também exclusivo e de representação do seu poder político e econômico.

\begin{abstract}
(...) em qualquer caso, ele [o capital produtor de moradias] desenvolve uma ideologia (a venda de um novo estilo de vida, mais moderno e seguro) em torno da 'nova' forma de morar, com vistas a tornar prematuramente obsoletos os bairros residenciais existentes para criar mercado para seus lançamentos e reduzir o tempo de rotação de seu capital. Esses estratagemas (...) têm tão-somente contribuído para acelerar a produção de novos bairros e o obsoletismo dos existentes. (VILLAÇA, 2001, p.184).
\end{abstract}

Assim como a obsolescência dos antigos bairros residenciais, a produção do "obsoletismo" do centro tem origem nesses interesses do mercado imobiliário e das camadas de alta renda, que sempre dominaram o processo de produção dos espaços urbanos a fim de garantir a reprodução e acumulação do capital. Essa constante produção de novos espaços exclusivos, novos "estilos de vida" e produtos imobiliários - uma lógica do "novidadesco" - está na base do abandono do centro (das elites) e dos bairros do seu entorno. O surgimento de novos subcentros - e dos shopping centers - voltados às camadas de alta renda refletiu fortemente no desenvolvimento e

92 O shopping Iguatemi, na Avenida Faria Lima, foi inaugurado no final dos anos 60. 
papel do centro da cidade como espaço para o consumo dessas classes. As atividades de comércios e serviços mais sofisticados, que até a década de 1950 e 1960 se concentravam no centro (diga-se "Centro Novo", a oeste do Anhangabaú), passaram a ocupar porções mais afastadas na direção sudoeste e mais acessíveis por automóveis, nas proximidades - ou mesmo no meio - dos bairros de alta renda. O centro e a área central deixaram de ser a principal localização para os investimentos privados do mercado imobiliário, assim como deixaram de ser o principal lugar de concentração de empregos das camadas de alta renda, os quais passaram a se localizar nos novos subcentros do setor sudoeste. Seria o terceiro movimento de abandono.

Esse período, no entanto, foi caracterizado por movimentos de permanência e mudança, em que "diversos movimentos contraditórios se sobrepõem, se articulam e se entrecortam" (FELDMAN, 2004, p.41). Ao mesmo tempo em que ocorria a dispersão das atividades econômicas voltadas às elites e sua saída do centro, houve uma intensificação dos usos e ocupação do mesmo e dos bairros de seu entorno, com construções de grandes edifícios verticais de uso misto e aumento do tráfego de veículos, transformando diversos espaços públicos em estacionamentos.

Destaca-se a tipologia kitchenette, menor subdivisão vendável que garante altas possibilidades de lucro, e o quarto-sala e serviços. Os edifícios, em sua maioria com mais de 15 pavimentos e chegando a quase 30, associam o uso comercial e de serviços no pavimento térreo e, em muitos casos, outras tipologias de unidades, com dois ou três dormitórios. (...) Os edifícios-conjuntos se caracterizam por agregar múltiplas atividades cinemas, comércio, restaurantes, escritórios, ruas internas -, e os edifícios-galeria, pela articulação inovadora entre espaço edificado e espaço urbano. (FELDMAN, 2004, p.43-44, grifos nossos $)^{93}$

Apesar do movimento de abandono do centro, não se pode afirmar que tenha ocorrido uma total saída das camadas de renda média e alta, nem dos investimentos públicos, os quais permanecem nas décadas seguintes. Configurava-se, na verdade, uma mistura de usos e classes sociais, marcando uma maior heterogeneidade de renda do que no resto da cidade (LABHAB/LILP/CAIXA, 2006), com marcantes diferenciações internas na própria área central (bairros centrais) ${ }^{94}$.

Os tipos e localizações dos investimentos públicos em transporte, em especial aqueles que se deram durante as décadas de 1970-1980, tornaram o centro de São Paulo a área mais acessível por transporte coletivo e menos acessível por automóvel. Abordando a questão do controle

\footnotetext{
${ }^{93}$ Entre esses empreendimentos, destacam-se o Edifício Copan, a Galeria Metrópole, os edifícios São Vito e Mercúrio e diversos edifícios na Praça Roosevelt e na Avenida Nove de Julho.

${ }^{94}$ Com base em dados do Censo IBGE 2000, recente pesquisa pelo LABHAB/LILP/CAIXA (2006) considerou que a porção sudoeste da área central apresenta famílias com maior renda (maior porcentagem de chefes de família com renda superior a 10 salários mínimos) e a porção nordeste, famílias de menor renda (maior porcentagem de chefes de família com renda entre 1 e 3 salários mínimos).
} 
sobre as condições de deslocamento, Villaça (2001, p.333-334) se remete à relação entre a dificuldade de acesso ao centro por automóvel e seu abandono pelas elites ao falar da metrópole norte-americana. Afirma que o centro é o local onde o automóvel tem maiores dificuldades e se depende mais de transporte público, e que assim ele se torna a "pior localização".

Acreditamos que essa reflexão, mesmo específica da realidade norte-americana, pode contribuir no entendimento do atual papel do centro e da área central na estrutura urbana de São Paulo. Alguns estudos afirmam que o aumento da acessibilidade da área central, devido à implantação e consolidação de um sistema de transporte coletivo ${ }^{95}$ que tem no centro seu ponto nodal, seria uma das causas da mudança no perfil dos usuários do centro - sua popularização -, especialmente a partir de 1985. Assim, "de forma geral pode-se afirmar que os espaços comerciais adaptaram-se a popularização do centro, que se tornou um espaço privilegiado do comércio popular" (SILVA, 2004, p.12).

Diante do processo de abandono do centro pelas elites, muitos imóveis ficaram vazios, ociosos e sem conservação, e seus proprietários se postaram “à espera de circunstâncias mais favoráveis e unicamente preocupados em obter maiores rendimentos" (MULLER, 1958, p.179). Intensificavase a especulação dos terrenos da área central - muitas vezes transformados em estacionamentos, através da demolição de edificações existentes - como um mecanismo da valorização imobiliária.

Os bairros do entorno do centro também passaram por processos similares, inclusive o subcentro do Brás, cujo desenvolvimento não tinha afetado a importância e papel do centro principal até então (VILLAÇA, 2001). Com a fuga das pequenas e médias burguesias dos bairros a leste, o centro do Brás também entrou em declínio - se popularizou (op.cit., p.312). Consolidava-se uma relação de indissociabilidade entre o centro propriamente e o centro do Brás, assim como entre o centro e os bairros de seu entorno (FELDMAN, 2004), ainda que o processo de abandono tenha ocorrido de diferentes formas e intensidades em cada porção central.

Em meio aos seguidos movimentos de abandono do centro pelas classes dominantes, desde o início do século XX, como vimos, este espaço tornou-se o mais disputado pelos diversos grupos sociais, sendo o "ponto" da cidade que mais otimiza os deslocamentos. Diante destas disputas, as ações do Estado - higienização, saneamento, embelezamento, sistema viário, legislações, etc. -

\footnotetext{
95 A construção das linhas Norte-Sul (1968-1974) e Leste-Oeste (1975-1986) do Metrô, a consolidação dos terminais de ônibus do Parque Dom Pedro II e da Praça da Bandeira, entre outros equipamentos. Como já notado, segundo alguns estudos, as dificuldades na micro-acessibilidade por automóveis ao centro também se dariam em função da existência dos calçadões e das inúmeras vias expressas que o cortam. Essas últimas permitem passar por ele, mas não necessariamente acessá-lo (MEYER, 1999).
} 
foram fundamentais para produzir um centro exclusivo e destinado às camadas de alta renda, expulsando classes sociais e usos indesejados.

No entanto, mesmo com o controle exercido por essas classes dominantes sobre a produção de um espaço de representação de seu poder, não significa que a área central tenha de fato um espaço homogêneo ${ }^{96}$ ocupado apenas por essas camadas e usos sofisticados. Ao contrário, porções do espaço central estiveram permeadas por usos populares, fossem nas chamadas "zonas de transição" (MULLER, 1958) entre o centro e os bairros do seu entorno, fossem nas porções a leste que foram gradualmente deixadas para trás pelas camadas de alta renda.

Os bairros dos Campos Elíseos, Santa Cecília e Santa Ifigênia, ao terem sido abandonados pelas camadas de alta renda, ainda nas primeiras décadas do século XX, passaram a ser ocupados por cortiços, vilas e usos populares. Mesmo tendo diminuído em número a partir das limitações à moradia de aluguel e da difusão da idéia da casa própria - anos 30 e 40 - a modalidade da habitação de aluguel em cortiços continuou existindo ao longo de todo o século XX. Ainda que a maioria da população tenha buscado a solução da casa própria em áreas periféricas, uma importante quantidade de habitações precárias de aluguel se manteve na área central, abrigando uma parcela da população de baixa renda que via nessa solução algumas vantagens em relação aos deslocamentos necessários para o trabalho (SILVA, 2000).

Segundo Muller (1958), em conjunto com a intensificação da verticalização nos anos 40 e 50, as “zonas de transição" passaram a ser ocupadas por vilas e "miseráveis" cortiços, devido à expansão da área ocupada pelas atividades e funções tipicamente centrais e da alta valorização dos terrenos. Vê-se que a própria valorização da área central - um fator tido como essencial para a constituição da exclusividade do espaço - permitiu também a ocupação de algumas de suas porções por cortiços e vilas precárias, que eram (e continuam sendo) formas rentáveis de produção do espaço (MULLER, 1958; BONDUKI, 1998; KOHARA, 1999). Conforme apontado por Muller, procurava-se melhor aproveitar os terrenos que se valorizavam, através da “subdivisão e melhor aproveitamento dos quarteirões” (MULLER, 1958, p.178).

(...) na ânsia de aproveitar da melhor maneira os terrenos de alto preço, os que vivem nessa área da cidade se vêem levados a abrir ruas internas, vielas e becos, onde se alinham incontáveis "vilas", desde as que se constituem de residências de tipo médio até aquelas que não passam de miseráveis "cortiços". (...) notadamente para os lados da Liberdade e da

\footnotetext{
96 Alguns autores têm formulado críticas ao chamado modelo centro-periferia de explicação da realidade urbana, frente às especificidades intrínsecas ao processo de produção do espaço metropolitano ao longo do século XX. Segundo esses autores, as noções de centro e de periferia, pelos pressupostos desse modelo, consideram um alto grau de homogeneidade do urbano, em geral, associando a primeira noção à verticalização e a segunda à autoconstrução (ou ao padrão periférico de crescimento urbano). Portanto, as explicações do modelo ignoram as lacunas e contradições presentes na produção e apropriação do espaço urbano, os diversos agentes sociais e interesses envolvidos, bem como as diferentes formas dessa produção do espaço. Ver Pereira (2005); Ribeiro e Lago (1994).
} 
Bela Vista. Por outro lado, a valorização dos terrenos tem ocasionado uma cada vez maior penetração dos arranha-céus nessa zona de transição, principalmente na Vila Buarque e em Santa Cecília. (op.cit., loc.cit.)

Pode-se afirma, portanto, que a idéia formulada ao longo do século XX de centro e área central como espaço homogêneo, ocupado apenas pelas camadas de alta renda e onde era realizada apenas a produção imobiliária intensiva (vertical) - típica das áreas mais valorizadas - produziu lacunas explicativas e mascarou as disputas políticas inerentes à produção espaço urbano. Ao desconsiderar a ocupação da área por grupos de menor renda, essa idéia compôs a representação simbólica e cultural das classes hegemônicas, serviu ao exercício de sua dominação sobre e

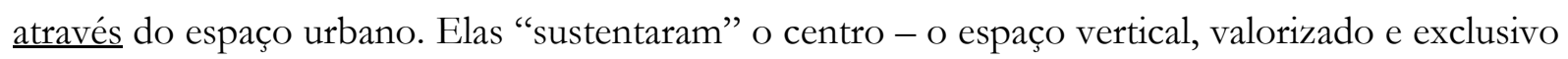
- e vice-versa.

São essas distinções que fazem com que, sendo objeto de disputa entre as classes, o centro
se torne mais acessivel a uns do que a outros, através dos mais variados mecanismos: desde
o desenvolvimento de um sistema viário associado a determinado tipo de transporte, até o
deslocamento espacial do centro e suas transformações (sua decadência ou pulverização,
por exemplo). As transformações territoriais por que passaram e continuam passando os
centros de nossas cidades são fruto dessa disputa (...) (VILLAÇA, 2001, P.243)

Da mesma forma, a idéia de deterioração ou degradação da área central, pressupondo uma homogeneidade anterior, tem contribuído para a manutenção da condição dominante das camadas de alta renda, expressa no espaço urbano. Porém, como já abordamos, o aumento da ocupação da área por camadas de baixa renda, por moradias coletivas precárias e comércios e serviços informais, tem exacerbado as disputas pela área central da cidade, principalmente a partir da década de 1980 com o processo de democratização política e o fortalecimento de movimentos sociais urbanos.

\subsection{DELIMITANDO O PROBLEMA: CENTRO DE QUE? CENTRO DE QUEM?}

O centro se expandiu e se deslocou em direção aos bairros de alta renda, constituindo o chamado "centro expandido" ou "novo centro". As atividades de comércios e serviços se espalharam por diversas áreas da cidade, misturando-se aos bairros residenciais de forma fragmentada, dispersa e atomizada, em especial nas porções sudoeste, chegando a alcançar as regiões da Avenida Faria Lima, Marginal do Rio Pinheiros e Avenida Luis Carlos Berrini. Sua delimitação é complexa e altamente controvertida (VILLAÇA, 2001).

No entanto, não é desse "novo centro" que tratam as atuais práticas do planejamento urbano em São Paulo quando se fala em revitalização, requalificação ou reabilitação do centro e da área central. Mas sim do espaço que foi "abandonado" pelos interesses das camadas de alta renda, do 
mercado imobiliário e do próprio Estado. Esse espaço urbano "abandonado" e que teve um aumento da freqüência de camadas populares, por sua vez, não se restringe ao centro propriamente, aos chamados Centro Velho e Centro Novo - atuais distritos Sé e República. Ele engloba também os bairros do entorno que sofreram a expansão do centro ao longo do século XX e passaram por processos similares de transformação - abandono pelas camadas de alta renda, aumento de sua ocupação por camadas de baixa renda e desvalorização. A partir da expansão do centro e da ocupação desses bairros do entorno pelas atividades centrais, foi formada uma unidade urbana - a área central - que segundo Feldman (2004) ganhou caráter de centro deselitizado e metropolitano.

\footnotetext{
Exaustão do território das elites, ampliação do comércio e serviços para outras camadas de renda, expansão horizontal e vertical em grande escala, mudança qualitativa dos empreendimentos imobiliários e ampliação das funções centrais e extralocais são os processos que conferem ao Centro de São Paulo seu caráter deselitizado e metropolitano. (FELDMAN, 2004, P.41).
}

Ao mesmo tempo, essa área central apresenta muitas diferenciações internas, as quais vêm se configurando desde o início do século XX em função dos deslocamentos dos bairros de alta renda. O lado leste e norte, assim como os bairros centrais localizados nessa direção, foram ocupados com maior intensidade por camadas de mais baixa renda - incluindo o centro do Brás e os bairros do Pari, Bom Retiro, parte da Mooca e do Belém. Nessa área há grande presença de antigos de galpões industriais ociosos e habitações de renda média e baixa. Já as porções oeste e sul, assim como os bairros desse lado, estiveram conectadas com o sentido de expansão dos bairros das elites e, conseqüentemente, foram ocupadas por comércios e serviços mais sofisticados e modernos. São essas porções que apresentam atualmente certa concentração de empresas do chamado "terciário avançado", como apontado anteriormente, e predominância de uso residencial de alta renda - Consolação, Higienópolis, Bela Vista.

Nesse sentido, a área central enquanto unidade urbana não é, e nunca foi homogênea, assim como o próprio centro, que desde o começo do século era dividido em Centro Velho e Centro Novo, em duas porções distintas. Esses dois "lados" da área central passaram por transformações, foram abandonados pelas camadas que os freqüentavam - alta, média e pequena burguesias - e tiveram mudanças de usos e ocupações. As camadas de alta renda, em conjunto com o Estado e o mercado imobiliário, abandonaram o centro. No entanto, ainda precisam manter seu controle sobre ele para preservar sua condição de classe dominante.

O centro 'velho' continua tendo um grande valor afetivo, cultural e simbólico para a grande maioria da população. Sim, porque só agora ele é da maioria. Antes era da minoria. Para manter sua condição de classe dirigente a burguesia não pode abandonar completamente o centro que, para ela, não tem mais interesse. Assim, o Estado, por um lado, faz algumas 
obras no centro (Vale do Anhangabaú ${ }^{97}$ ), mas por outro abandona-o (VILLAÇA, 1995, P.206)

A área central - uma unidade urbana - poderia ser delimitada pelos distritos da atual Subprefeitura Sé, alguns distritos da Subprefeitura Mooca e talvez algumas parte da Subprefeitura Lapa: Sé, República, Bom Retiro, Santa Cecília, Consolação, Bela Vista, Liberdade, Cambuci, Brás, Pari, Mooca, Belém e Barra Funda. No entanto, são muitas as delimitações possíveis, representando diversos entendimentos e interesses: o centro propriamente (distritos Sé e República); os bairros centrais no entorno do centro (demais distritos da atual Subprefeitura Sé); ou mesmo a anexação de alguns distritos de outras Subprefeituras.

O aparente consenso em relação ao Centro de São Paulo oculta o debate entre essas diferentes estratégias [de intervenção] e seus possíveis matizes, assim como diferentes limites internalizam diferentes interesses e princípios urbanísticos. Ou seja, restringir a Sé e República ou incluir oito ou seis distritos que os envolvem como território a ser objeto de uma política urbana específica pressupõe diferentes interpretações do Centro, diferentes direções para essa política, diferentes atores e, necessariamente, processos de implementação diversos (FELDMAN, 2004, P.40)

Essas diferentes abordagens da área central - também diferentes interesses e princípios urbanísticos - podem ser notadas nas propostas do Programa Ação Centro, através da delimitação de sua Área de Interesse nos distritos Sé e República, ou seja, naquilo que comumente se entende por centro. Ainda que tenha incorporado projetos e ações que incidem fora dessa área, como vimos no capítulo anterior, os objetivos principais do programa recaiam sobre ela.

Em estudo contratado pela EMURB ao Cebrap/CEM (Centro Brasileiro de Análise e Planejamento/Centro de Estudos da Metrópole), no âmbito do financiamento do BID, foram elaborados diagnósticos da área central, posteriormente publicados no livro "Caminhos para o Centro" (PMSP/EMURB 2004e). Segundo Somekh (2004c, p.IV) os estudos apresentados na publicação "são fruto de um esforço de compreensão da dinâmica econômica do centro. A identificação das potencialidades e perspectivas dos diferentes setores que compõem a estrutura produtiva da área central fornece subsídios que permitem o estabelecimento de estratégias para as ações de desenvolvimento". Vê-se que os diagnósticos apresentaram um enfoque econômico, tratando das seguintes questões: concentração de atividades econômicas e de empregos; dinâmica

${ }^{97}$ Referindo-se as obras de reurbanização do Vale no começo da década de 1990, associadas à Operação Urbana Anhangabaú. 
do comércio informal; funções culturais, terciárias e financeiras existentes e suas tendências atuais; processos de desvalorização imobiliária; dinâmica imobiliária na cidade e suas características específicas na área central; bem como análise de outras experiências de recuperação de áreas consideradas degradadas; e de possíveis mecanismos de intervenção.

A partir destes estudos, Comim (2004) realizou uma sistematização das principais questões apontadas, enfocando as potencialidades e problemáticas estruturais da área. Sua delimitação da área central considerou os distritos da Subprefeitura Sé (Sé, República, Liberdade, Bela Vista, Consolação, Santa Cecília, Cambuci e Bom Retiro), incorporando os distritos Brás e Pari devido à existência de atividades econômicas contíguas e importantes, mas priorizando o Centro Histórico (distritos Sé e República). Retomou as análises sobre o esvaziamento do centro e da área central, relativizando esse fenômeno, uma vez que ele ocorre quase que exclusivamente em relação ao uso residencial, mesmo com a perda de atividades econômicas diante da transformação do centro em "mero nó de articulação e passagem". Apontou que ainda existe considerável concentração de atividades financeiras, principalmente no Centro Velho, alguns ramos de comércio especializado, entre outros.

De maneira geral, os diagnósticos apontaram grande heterogeneidade na área central, percebida tanto pelos tipos de usos e atividades, quanto pelo perfil sócio-econômico de moradores e usuários, sendo que cada artigo publicado deteve-se sobre um aspecto dessa diversidade. Baseando-se no conjunto de estudos, mas principalmente no de Vagner de Carvalho Bessa, que enfocou as atividades de prestação de serviços a empresas, Comin (2004) apontou uma diferenciação entre os bairros da porção nordeste do centro, e aqueles a sudoeste; esses últimos ocupados por camadas de renda mais alta e caracterizados por certa concentração de atividades terciárias “modernas", aproximando-se das características do vetor sudoeste da cidade.

No entanto, mesmo que os estudos tenham apresentado heterogeneidades e diferenciações internas à área central, numa análise cuidadosa sobre os tipos de atividades que a ocupam, a decisão tomada no âmbito do Programa Ação Centro foi focalizar os investimento naquilo que comumente se entende por centro - distritos Sé e República. Se considerarmos o que foi exposto neste capítulo, tal focalização contribuiu para uma leitura ideológica do espaço e desconsiderou suas diferenças internas, bem como os conflitos existentes, correspondendo a estratégias e objetivos de intervenção urbana que têm sido amplamente difundidos e considerados exemplos a serem seguidos, como veremos no capítulo seguinte. 


\section{CAPÍTUlO 3. MODELOS URBANÍSTICOS E DE GESTÃo PÚBLICA}

A verificação dos modelos de intervenção e gestão urbana que foram adotados no Programa Ação Centro exigiu a análise de seus principais referenciais urbanísticos, da influência dos "padrões" do BID sobre sua estrutura programática e de um conjunto de instrumentos urbanísticos que foram considerados essenciais para o alcance de seus objetivos ou de parte de seus componentes, em especial o habitacional. A definição destas questões de análise partiu do exame dos documentos oficiais do programa e das entrevistas com técnicos envolvidos nas negociações com o banco financiador e na montagem do programa.

Primeiramente será abordado o conjunto de experiências estrangeiras de recuperação de áreas urbanas consideradas degradadas que ocorreram nas últimas 3 décadas em cidades de países centrais do capitalismo, com diversos enfoques e correspondendo a diferentes modelos de desenvolvimento urbano. A análise das propostas urbanísticas paulistanas anteriores a 2001 e dos discursos de agentes sociais interessados na recuperação da área central, nos mostrou que tais experiências foram amplamente divulgadas em São Paulo ao longo dos anos 1990, em especial as que se pautaram nos princípios urbanísticos do chamado planejamento estratégico - o gerenciamento urbano empresarial para salvar as cidades "em crise". Essa difusão permeou também a estruturação do Ação Centro, em suas estratégias de recuperação da área central mediante investimentos públicos prévios para gerar atração de capital privado.

Um outro modelo internacional que também será abordado neste capítulo é aquele que se pautava na atuação de um Estado forte sobre o controle da produção do espaço urbano, a fim de garantir a fixação da população de baixa renda em áreas que passavam por processos de reabilitação urbana. Tal modelo serviu de referência para a estruturação das iniciativas do campo 
habitacional que foram inseridas no escopo programa Ação Centro, a exemplo do que foi realizado na França e em Portugal.

$\mathrm{Na}$ seqüência, consideramos um segundo fator da estruturação do programa, que reforçou seu alinhamento as experiências estrangeiras do planejamento estratégico: sua adequação aos padrões do banco financiador, as determinações para sua aprovação e para liberação dos recursos, configurando um modelo de gerenciamento público de cunho neoliberal. Tal modelo, seguindo os ajustes fiscais que vinham sendo operados pelos organismos multilaterais de crédito - Banco Mundial, BID - desde os anos 1980, foi fundamental para a difusão das práticas urbanísticas pautadas no planejamento estratégico. Apesar de possuir um discurso menos enfático, se comparado ao Banco Mundial, em relação à formulação programática de suas políticas (ARANTES, 2004), o BID vinha financiando diversos projetos de "revitalização urbana" que serviram de exemplos "exitosos" - junto com experiências européias e norte-americanas - para a montagem do Programa Ação Centro. São as "best practices" difundidas e recomendadas pelo banco.

Mesmo que a importação desses modelos de recuperação de áreas urbanas "degradadas" - dos seus princípios urbanísticos e gerenciais - tenha sido apontada por diversos autores como "fatais" (ARANTES, 2000), acirrando as desigualdades e privilégios na realidade urbana brasileira - ou, nas palavras de Maricato (2000), como "idéias fora do lugar" - a difusão de experiências "de sucesso" estabeleceu o contexto em que o Ação Centro foi montado. Contexto esse recheado da fraseologia neoliberal, em que a estratégia urbana defendida é transformar o perfil de uso e ocupação de áreas "decadentes”, mediante "projetos-âncora" e intervenções públicas de melhoria do ambiente urbano, capazes de gerar a necessária atração de investimentos privados.

Por fim, abordamos os instrumentos urbanísticos que foram apresentados pelos documentos do Ação Centro como essenciais para o alcance de seus objetivos e que foram regulamentados no Plano Diretor Estratégico do Município (PDE - Lei Municipal 13.430/2002), num contexto de entusiasmo decorrente de aprovação do Estatuto da Cidade (Lei Federal 10.257/2001) em âmbito federal. No bojo da Luta pela Reforma Urbana e influenciada pelo início da implementação dos programas habitacionais do Morar no Centro, a aplicação de muitos desses instrumentos visava garantir o cumprimento da função social da propriedade e criar incentivos à produção pública e privada de Habitação de Interesse Social (HIS) na área central. Entendia-se que eles seriam fundamentais para efetivar o controle público sobre a produção do espaço urbano - conter a valorização e evitar a retenção especulativa de terrenos - garantindo, desse modo, um desenvolvimento urbano justo e democrático, contrapondo-se ao condicionante 
anterior e explicitando um antagonismo dos princípios norteadores e objetivos do Programa Ação Centro.

Ao mesmo tempo, contando com recursos do financiamento do BID $^{98}$, a elaboração dos Planos Regionais das Subprefeituras Sé e Mooca foi entendida como meio de operar a flexibilização da legislação urbanística, produzindo um "marco regulador estável” para os investimentos imobiliários - especialmente do setor terciário e de "última geração" (BID, 2004).

\subsection{EXPERIÊNCIAS ESTRANGEIRAS}

Referências a experiências estrangeiras de recuperação de áreas urbanas consideradas degradadas, realizadas a partir do final década de 1960 na Europa e América do Norte, estiveram presentes no Programa Ação Centro de diversas formas, ao longo de todo processo de montagem e negociação com o BID ${ }^{99}$. Permearam a definição de componentes, subprogramas e ações, as discussões com os atores sociais envolvidos com o tema da recuperação e as próprias exigências do banco financiador, como a concepção da forma de gestão e monitoramento, a criação de uma instância de gestão compartilhada e outra de gerenciamento.

Tais modelos seguem preceitos de intervenção e política urbana que se dizem contrários ao planejamento moderno, compondo um complexo quadro de referências, com diferentes abordagens. Variam desde as experiências denominadas de Reabilitação Integrada, realizadas a partir de uma forte intervenção estatal e da estruturação de uma política de habitação de âmbito nacional, associada à preservação do patrimônio histórico não monumental, até aquelas que se pautaram nas técnicas do aclamado planejamento estratégico, com base em parcerias públicoprivadas e em projetos pontuais (“acupunturais”). Essas últimas se constituíram em práticas dominantes de intervenção e gestão urbana, sendo amplamente difundidas na América Latina.

\subsubsection{NOVAS PRÁTICAS URBANÍSTICAS: UMA BREVE CONTEXTUALIZAÇÃO}

Apesar de possuírem diferentes abordagens, as experiências internacionais que permearam a montagem do Programa Ação Centro ocorreram num mesmo contexto político e sócioeconômico, que se desenrolou a partir do final da década de 1960, marcado pela crise de

\footnotetext{
98 Há informações desencontradas sobre este aspecto. Segundo POLIS/CARE (2007, p.57), a elaboração dos planos regionais prevista para ser executada com recursos do BID, virou contrapartida da Prefeitura.

99 Podemos perceber que referências a modelos internacionais estavam presentes, inclusive, nas versões anteriores apresentadas ao Ministério do Planejamento e ao banco financiador - cartas-consultas de 1997 e 2002.
} 
acumulação de capital, pela chamada reestruturação produtiva e pelo enfraquecimento do modelo keynesiano de Estado de Bem-Estar Social. Seria o que correntemente tem se chamado de "globalização"; uma "reviravolta" da economia mundial, de suas estruturas produtivas e seus desdobramentos espaciais, culturais, políticos e sociais.

Diversos autores nacionais já realizaram análises sobre essas recentes transformações, com diferentes enfoques e abordagens, refletindo sobre o que é realmente novo nesse processo, como ele ocorreu em países periféricos do capitalismo, como o Brasil, e sua dimensão espacial (ARANTES, 2000; VAINER, 2000; MARICATO, 2000; DEÁK, 2001; OLIVEIRA, 2003; FERREIRA, 2007; FIX, 2007). Sem a pretensão de refazer a análise, enfocamos nesse trabalho apenas alguns tópicos principais, a partir dos quais pudemos caracterizar o momento histórico em que as novas práticas urbanísticas se desenvolveram nos países centrais.

O período do pós-guerra na Europa foi marcado por um enorme crescimento econômicoindustrial, com base nos empréstimos do Plano Marshall, na reconstrução das cidades e de sua infra-estrutura produtiva, e no fortalecimento do Estado de Bem-Estar Social. Políticas de saúde, educação, previdência e trabalhistas foram implementadas a fim de melhorar a qualidade de vida - e a capacidade de consumo - das classes trabalhadoras. Os sistemas de regulação e controle estatal sobre a reprodução da força de trabalho e sobre a própria acumulação foram fundamentais para garantir o ciclo de reprodução do capital e o crescimento econômico de modelo fordista.

O movimento moderno na arquitetura e planejamento urbano ganhava força, consolidando os princípios da massificação/industrialização da construção civil, da racionalização e funcionalidade do espaço urbano - o chamado modernismo "universal" ou "alto", que se tornou hegemônico após 1945 (HARVEY, 1992, p.42). Pressupunha-se um Estado forte, pautado em mecanismos de controle da produção do espaço urbano e da especulação imobiliária e fundiária, e que garantisse a toda população os direitos básicos do Estado de Bem-Estar, especialmente habitação e infraestrutura. Cidades européias passavam por diversas obras de reconstrução e tiveram massiva produção de habitação social de aluguel, seguindo os preceitos modernos.

Do modernismo, esse planejamento urbano ganhou a herança positivista, a crença no progresso linear, no discurso universal, no enfoque holístico. Da influência keynesiana e fordista, o planejamento incorporou o Estado como a figura central para assegurar o equilíbrio econômico e social, e um mercado de massas. (MARICATO, 2000, p.126)

Apesar de apresentar algumas diferenças em cada cidade européia - ora preservando algumas edificações históricas, ora demolindo-as em massa - o processo de reconstrução do tecido urbano destruído pelos bombardeios da guerra - principalmente das áreas centrais das cidades enfocou a recuperação das estruturas físicas, sem atenção à estrutura social (CERVELLATI, 
1976). Realizava-se uma substituição das edificações existentes e dos usos tradicionais, adequando os centros urbanos para a instalação de "atividades direcionais, comerciais especializadas e para residência de luxo ou turística" (CERVELLATI, 1976, p.7), através da demolição do velho seguida da construção do novo. Era a chamada Renovação Urbana, já amplamente utilizada em cidades "envelhecidas" dos Estados Unidos, seguindo "as idéias do CIAM, de Le Corbusier e de Mies van der Rohe" (HARVEY, 1992, p.42).

No entanto, o ritmo de crescimento econômico se esgotava após a intensa reconstrução, em especial devido à introdução de novas tecnologias de produção e às dificuldades em manter os elevados níveis de consumo (FERREIRA, 2007) - e consequentemente a qualidade de vida da população - gerando uma crise de desemprego e superprodução. Somado a isso, como aponta Arantes (2000, p.43), com base nas observações de André Gorz, "as proteções e prestações do Estado-Providência não haviam reconciliado as populações com a ordem capitalista". Pelo contrário, os efeitos das revoltas e greves de 1968 se espalharam por todo tipo de instituição e mostraram que o fundamento central do capitalismo estava sendo questionado: o "mecanismo de reprodução simbólica da sociedade" (op.cit, loc.cit, grifos no original). As revoltas do fim dos 1960, em especial na Europa (Itália e França), mas também na América do Norte com as manifestações pelos direitos civis e contra a guerra no Vietnã, demonstravam o descontentamento com aquela sociedade, incluindo os projetos modernos de habitação e renovação (ARANTES, 2000, p.23), instaurando uma crise de governabilidade.

\footnotetext{
Antagônicas às qualidades opressivas da racionalidade técnico-burocrática de base científica manifesta nas formas corporativas e estatais monolíticas e em outras formas de poder institucionalizado (...), as contraculturas exploram os domínios da auto-realização individualizada por meio de uma política distintivamente "neo-esquerdista" da incorporação de gestos antiautoritários e de hábitos iconoclastas (...) e da crítica da vida cotidiana. (...) Foi quase como se as pretensões universais de modernidade tivessem, quando combinadas com o capitalismo liberal e o imperialismo, tido um sucesso tão grande que fornecessem um fundamento material e político para um movimento de resistência cosmopolita, transnacional e, portanto, global, à hegemonia da alta cultura modernista. (HARVEY, 1992, p.44).
}

Nesse contexto, questionamentos aos princípios modernos do planejamento começavam a emergir, rechaçando suas posturas homogeneizantes, racionalistas e funcionalistas, consideradas em última instância, autoritárias. Uma nova esquerda surgia, com base na contracultura vinda do bojo dos descontentamentos e revoltas (ARANTES, 2000 p.42), que no campo do urbanismo, pretendia-se o contraponto às ações de Renovação Urbana do pós-guerra e aos preceitos modernos, propondo novas práticas urbanísticas (CERVELLATI, 1976; LOPES; 2000; BOUCHE, 2000; ZANCHETI, 2003). Seria o que Nuno Portas (1985) chamou, mais tarde, de “intervenção na cidade existente". 
O texto da jornalista norte-americana Jane Jacobs, "The death and life of great American cities" $(1961)^{100}$, tem sido considerado pioneiro (HARVEY, 1992; DEL RIO, 1990) nas críticas aos preceitos modernos e às ações de renovação, que ela aponta como responsáveis pela ordenação do caos e pelo controle dos conflitos e, conseqüentemente, pela morte da diversidade, complexidade e riqueza das cidades - fatores ignorados pelos planos modernos. Seus escritos inspiraram alguns movimentos nos Estados Unidos que buscavam, assim como na Europa, atentar para as especificidades e culturas locais, permitindo a participação da comunidade local na elaboração e implementação de projetos. Segundo Zancheti (2003, p.95), os "grass roots movements" são um exemplo que, apesar de resultar em certo grau de "gentrificação" do tecido urbano, buscavam realizar recuperações de áreas centrais e bairros residenciais com base na organização comunitária, na atuação de pequenos e médios empreendedores e no apoio das administrações locais.

Del Rio (1990) também destaca o caráter funcionalista, homogêneo e autoritário dos programas de renovação, com enfoque no caso norte-americano, em que importantes fatores da vida urbana eram ignorados: "patrimônio históricos, da integração e inter-relação entre as funções e atividades humanas, a importância das redes sociais estabelecidas, dos valores afetivos" (DEL RIO, 1990, p.20). Segundo o autor, foi justamente do questionamento a esses programas que surgiu o Desenho Urbano, se consolidando como "campo de conhecimento". Uma passagem da escala do plano para a escala do projeto, buscando atentar para as especificidades locais e realizando intervenções em áreas "degradadas" - fazendo com que a idéia de "requalificação" se passasse à ordem do dia. (ARANTES, 2000, p.15)

(...) contra as características do Planejamento Urbano dos anos 60, tais como o formalismo, os modelos estáticos, a tecnocracia, a rigidez e a pretendida amplitude, vieram opor-se características do Desenho Urbano, como a informalidade, os modelos dinâmicos, a participação comunitária, a flexibilidade e a especificidade. (DEL RIO, 1990, P.44)

Já no final da década de 1960, observava-se uma saída de atividades econômicas tradicionais de áreas centrais e sua instalação em áreas periféricas ou em municípios vizinhos, bem como um aumento de atividades terciárias ocupando os centros urbanos, incentivadas pelas ações de renovação, gerando um processo de expulsão de moradores e usos tradicionais. Ao mesmo tempo, as ofertas de novas habitações (conjuntos modernos) se localizavam principalmente em áreas distantes dos centros, contribuindo para uma periferização do crescimento urbano. Os urbanistas Pier Luigi Cervellati, Roberto Sacannavini, Carlo De Angelis e Giuseppe Campus Venuti, ao observarem esse processo em cidades italianas, construíram uma metodologia de 
intervenção urbana que buscava reverter essa lógica, enfocando a preservação e melhoria dos bairros residenciais centrais e propondo uma "volta à cidade", com atenção à cultura e às especificidades locais - uma abordagem tipológica e morfológica.

Posteriormente chamada de Conservação Integrada (CI), essa metodologia teve origem no urbanismo reformista italiano das décadas de 1960 e 1970, especificamente na cidade de Bolonha com a ascensão e significativa permanência do Partido Comunista Italiano (PCI) no poder público municipal. Sua consolidação, enquanto prática urbanística, deu-se com o Manifesto e a Declaração de Amsterdã de 1975 (Cartas Patrimoniais), e sua difusão pela Europa, em especial por cidades espanholas e do norte da Itália (LUCINI, 1996; ZANCHETI, 2003).

Segundo Zancheti (2003), as primeiras experiências embasadas nos princípios da CI foram realizadas em bairros dos centros históricos das cidades européias, dando ênfase à recuperação das antigas edificações e à dimensão social das intervenções, ou seja, buscando garantir a permanência dos moradores originais, geralmente de baixa renda, nas residências recuperadas. Posteriormente, tais princípios foram apropriados tanto por políticas progressistas como neoliberais - ainda que de forma distorcida - permeando tanto as metodologias portuguesas e francesas de Reabilitação Integrada, como as "experiências de mercado" realizadas nos Estados Unidos e em alguns países da Europa; essas últimas denominadas de planejamento estratégico. Como já apontou Arantes (2000, p.23), “foi quando, no início dos anos 1970, toda essa movimentação [contracultura, resistências e posições anti-sistêmicas] acabou sendo 'capturada' por forças bem diferentes e empregadas para fins bem distintos”.

Por uma breve temporada pareceu possível emperrar a máquina urbana de crescimento ${ }^{101}$, contrapondo ao núcleo duro produtivista do sistema a cidade como valor de uso. (...) Nada mais antivalor (de troca) do que o "lugar" redescoberto e contraposto ao espaço homogêneo dos modernos e do mercado. Portanto, muito melhor reabilitar do que demolir; intervenções, só em migalhas; reativar a memória porém evitando o assassinato meseográfico dos sítios históricos; valorizar o contexto, o babitat ordinário, reanimar a vida dos bairros, sem violentar os moradores(...) (ARANTES, 2000, p.44).

A crise econômica que se instalava, claramente visível na década de 1970, conduzia a ajustes nas formas de atuação pública sobre o espaço urbano, respaldando-se nas "resistências antiprodutivista" que abordamos acima, mas utilizando - ou "capturando" - seus discursos para

101 "Growth Machine", conceito teorizado por Harvey Molotch na década de 1970, em artigo publicado no American Journal of Sociology e posteriormente retomado em livro conjunto com John Logan, Urban Fotunes - the political economy of place. University Califórnia Press, 1987. Segundo Arantes, “... a idéia de cidade como growth machine pode ser assim resumida: coalizões de elite centradas na propriedade imobiliária e seus derivados, mais uma legião de profissionais caudatários de um amplo arco de negócios decorrentes das possibilidades econômicas dos lugares, conformam as políticas urbanas à medida em que dão livre curso ao seu propósito de expandir a economia local e aumentar a riqueza. (...) Com a retomada da hegemonia americana, vulgarmente conhecida como 'globalização', o modelo máquina-de-crescimento generalizou-se sob o pretexto de responder as mesmas pressões competitivas em torno do capital escasso e nômade, na verdade atendendo aos imperativos (políticos) da cultura anglosaxônica dos negócios, a ponto de converter num dado natural a convicção de que as cidades devem ser geridas não 'like business', mas antes 'for business"' (ARANTES, 2000, p.27, grifos no original). 
outros fins. Segundo Fernandes (2001) existem diversas correntes de interpretação da crise e dos ajustes que a sucederam, considerando algumas das soluções espaciais adotadas e as diversas terminologias que têm sido empregadas para denominar tais transformações, como "pósfordismo”, "pós-industrial”, "financeirização”, “acumulação flexível”.

Uma das correntes citadas pela autora, que parece ter sido dominante no debate urbano-regional internacional dos anos 90, é a que enfoca a "reestruturação produtiva". A chamada "Revolução

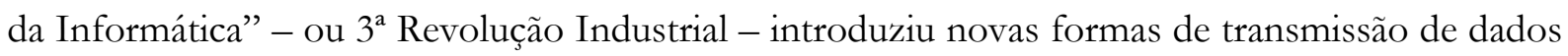
e informações, e contribuiu para o surgimento de novas estruturas produtivas, entre as quais a reengenharia, o sistema "just in time", a terceirização, etc. As inovações tecnológicas exacerbaram os níveis de produtividade e romperam com o modelo fordista de produção, aumentando o desemprego e aprimorando a divisão internacional do trabalho, ao mesmo tempo em que não se conseguia gerar consumo e escoar a produção - não se realizava o ciclo de reprodução do capital.

De modo geral, a partir da crise de acumulação, foram introduzidos ajustes para o aliviamento do Estado através de políticas de desregulamentação da relação capital-trabalho e da própria acumulação, houve um vertiginoso crescimento dos fluxos financeiros internacionais e intensificavam-se os movimentos de relocalização de empresas. Esses últimos ocorriam de acordo com as vantagens locacionais oferecidas por cada cidade - altas taxas de juros, flexibilização de legislações ambientais e trabalhistas - em que as atividades de marketing - das empresas e das cidades - ganhavam cada vez mais destaque. Receitas de cunho neoliberal eram adotadas para superar a crise econômica, "dando um novo fôlego e garantindo uma sobrevida do sistema capitalista" (FERREIRA, 2007, p.95), o que foi amplamente festejado e difundido, inclusive em seus rebatimentos na dimensão urbana, tornando-se um "pensamento único".

A acumulação de capital passou a se concentrar em grandes empresas corporativas transnacionais, aumentando a importância do setor de serviços "modernos" ligados a essas corporações - informática, telecomunicações, consultorias, publicidade, contabilidade, etc. - em detrimento do setor industrial. Um processo em que atividades produtivas tradicionais entravam em declínio, dando espaço para novas formas produtivas, o que Harvey (1992) descreveu como uma passagem da acumulação rígida (fordista) para uma acumulação flexível (pós-fordista).

Os ajustes e receitas adotados - disciplina fiscal, privatizações, diminuição dos gastos sociais (retirada do Estado), financeirização, flexibilização e desregulamentações - tinham seus rebatimentos nas cidades, levando ao surgimento de teorizações sobre os espaços adequados a nova fase da economia capitalista. Segundo Sassen (1998), com o processo de reestruturação produtiva, ocorreu uma mudança do eixo da acumulação de capital, que passou a ter como 
elemento central as transações financeiras internacionais e os serviços "modernos", concentrados em algumas grandes cidades. Nessa visão, os ajustes econômicos teriam dotado a escala local (cidades) de um papel fundamental na "nova" ordem capitalista, em detrimento da função reguladora dos estados nacionais.

À corrente interpretativa que enfoca a reestruturação produtiva foi associada, portanto, a hipótese sobre as "cidades-globais" "102. Segundo essa hipótese, o declínio do modo fordista de produção e suas decorrências - enfraquecimento dos Estados Nacionais, desregulamentação, flexibilização, financeirização, "globalização" - dotaram as cidades de um novo papel dentro do sistema capitalista, em especial algumas grandes cidades, como Nova Iorque, Londres e Tóquio. "Em vez de se tornarem obsoletas devido à dispersão que as tecnologias da informação possibilitaram, as cidades concentram funções de comando" (SASSEN, 1998:35-6).

(...) as transformações ocorridas durante as duas últimas décadas [1970 e 1980] na composição da economia mundial, acompanhando a mudança de direção na direção de prestação de serviços e das finanças, suscita a renovada importância das grandes cidades como locais destinados a certos tipos de atividades e funções. $\mathrm{Na}$ atual fase da economia mundial, é precisamente a combinação da dispersão global das atividades econômicas $e$ da integração global, que tem contribuído para o papel estratégico desempenhado por certas grandes cidades, que denomino cidades globais. (...) as cidades globais da atualidade são: (1) pontos de comando na organização da economia mundial; (2) lugares e mercados fundamentais para as indústrias de destaque do atual período, isto é, as finanças e os serviços especializados destinados às empresas; (3) lugares de produção fundamentais para essas indústrias, incluindo a produção de inovações. (SASSEN, 1998, P.16-7)

Nesta chave explicativa afirma-se que, ao lado da transnacionalização dos fluxos financeiros e da concentração da acumulação em poucas empresas corporativas transnacionais, a dispersão física da produção econômica decorrente da busca por mercados de trabalho e consumo mais atrativos e por legislações menos impeditivas - além das possibilidades alcançadas com as inovações da informática - teria fornecido às grandes cidades um papel central na economia mundial. As relações entre as dimensões global e local (FERNANDES, 2001) se dariam pela transformação de algumas grandes cidades em novas unidades espaciais da atual fase "global" do sistema capitalista, ou seja, pelo surgimento da "cidade-global", onde concentram-se grandes fluxos de capital e serviços - a dimensão urbano-espacial do Consenso de Washington (MARICATO, 2001).

102 Ferreira (2007) aponta que o termo "cidade-global" foi utilizado pela primeira vez em 1915 por Patrick Gueddes e retomada posteriormente por Peter Hall em 1966. Mas foi com Friedman (1982 e 1986) que o termo teria sido associado diretamente às transformações dos processos de acumulação de capital por que passava a economia mundial - financeirização, concentração de riquezas em empresas corporativas transnacionais, importância de grandes cidades na espacialização de determinados fluxos econômicos. FRIEDMANN, J. \& WOLFF, G. "World city formation: an agenda for research and action". In International Journal of Urban and Regional Research, v. 6, n. 3, setembro, p. 309-344, 1982. FRIEDMANN, J. "The World Cities hipotesys", in Development and Change, $\mathrm{n}^{\circ} 17$ (1), 1986. 
A partir da década de 1970, as "cidades-globais" viram o surgimento de novos "distritos de negócios" (os "business districts" norte-americanos), como Battery Park em Nova Iorque, La Défense em Paris e Docklands em Londres - "setores internacionalizados da economia urbana" como aponta Sassen (1998, p.77) - que provocaram valorização imobiliária de seus arredores (FERREIRA, 2007, p.71). Para viabilizar a criação desses distritos - estrategicamente localizados em áreas marcadas pela "degradação" e decadência de suas atividades econômicas - os poderes públicos locais coordenaram grandes operações de "revitalização urbana" de acordo com as técnicas do planejamento estratégico e do "city marketing" - as "experiências de mercado" a que se refere Zancheti (2003).

O planejamento urbano moderno, que já vinha sendo criticado, foi definitivamente rechaçado e considerado inadequado para resolver os problemas e necessidades das cidades contemporâneas - leia-se adequá-las à nova lógica econômica global - uma vez que ele pressupõe um alto grau de controle do Estado (VAINER, 2000), o que restringiria os ganhos e a livre iniciativa do capital sobre a cidade. Os ajustes urbanos que se processavam a partir da teorização das "cidadesglobais" e da introdução do planejamento estratégico, ao contrário da "nova esquerda" nascida dos movimentos contestatórios do final dos anos 60, buscavam canalizar o crescimento econômico das cidades para a lucratividade dos setores privados, através de projetos de "requalificação" de áreas urbanas "degradadas”, com base nas parcerias público-privadas. Como aponta Arantes (2000), esses projetos podem ser considerados um eufemismo de "gentrificação", utilizando uma vasta fraseologia que busca encobrir seus verdadeiros fins: "reconquistar" as áreas decadentes e acelerar a "máquina urbana de crescimento".

Daí a sombra de má consciência que costuma acompanhar o emprego envergonhado da palavra [gentrificação], por isso mesmo escamoteada pelo recurso constante ao eufemismo: revitalização, reabilitação, revalorização, reciclagem, promoção, requalificação, até mesmo renascença, e por aí afora, mal encobrindo, pelo contrário, o sentido original de invasão e reconquista, inerente ao retorno das camadas afluentes ao coração das cidades. (ARANTES, 2000, p.31)

Como afirmam Castells \& Borja (1996): "pode-se falar das cidades como atores sociais", em que os governos locais devem realizar uma cooperação público-privada e buscar uma "inovação democrática" no caminho de se tornarem promotores - e não mais reguladores - do desenvolvimento urbano. Essa seria a máxima do "novo" planejamento - gerenciamento - de cidades, que tem sido amplamente difundido, inclusive para cidades latino-americanas, tornandose um modelo dominante de intervenção urbana. 


\subsubsection{MODELOS DE INTERVENÇÃO URBANA EM ÁREAS CONSIDERADAS DEGRADADAS}

Identificamos a seguir duas diferentes abordagens das novas práticas urbanísticas de recuperação de áreas urbanas entendidas como degradadas, realizadas em cidades de países centrais do capitalismo, diante das críticas aos paradigmas modernos de planejamento urbano e no contexto que acabamos de apresentar. Essa identificação foi possível a partir do levantamento de algumas experiências significativas correspondentes a cada uma das abordagens e que foram consideradas referências para a montagem do Programa Ação Centro, ou de alguns de seus componentes, tendo sido indicadas ou não pelo banco financiador como exemplos a serem seguidos.

Primeiramente tratamos daquela que se constituiu em meio à contracultura do final dos anos 1960, compondo os objetivos e princípios urbanísticos da "intervenção na cidade existente", denominação dada por Nuno Portas (1985) e adotada neste trabalho. Em nossas análises, pudemos perceber que o componente habitacional (Morar no Centro) do Ação Centro tomou como referência as metodologias pautadas nesses princípios, com destaque para as experiências portuguesas e francesas, principalmente através do estabelecimento de convênios e intercâmbios (PMSP/SEHAB, 2004a). Se algumas dessas metodologias já estavam presentes em discussões e propostas realizadas durante a gestão Luiza Erundina (1989-1992), em especial no "Concurso de Idéias para a Reabilitação do Bairro do Bexiga", como vimos no capítulo anterior, elas foram ainda mais importantes para a concepção dos programas habitacionais que estavam em andamento e que foram inseridos no escopo do financiamento do BID, ainda que não tenham sido indicadas como exemplos pelo mesmo.

Por isso, sistematizamos alguns pontos relevantes dessa abordagem, tendo como base as experiências citadas e procurando identificar seus elementos comuns, ainda que sua formulação e implementação contenham especificidades, de acordo com o contexto e as características políticas, sociais, culturais e econômicas de cada país. Consideramos também a experiência italiana, em especial da cidade de Bolonha, como base para nossa sistematização, na medida em que ela se constituiu em uma iniciativa pioneira da "intervenção na cidade existente" (LUCINI, 1996; ZANCHETI, 2003).

$\mathrm{Na}$ seqüência, enfocamos a abordagem que se pautou no receituário da chamada "gestão urbana empresarial", envolvendo as técnicas de intervenção do planejamento estratégico de cidades e do “city marketing". Assim como nas iniciativas para o centro de São Paulo que ocorreram ao longo da década de 1990, notamos também que muitas das propostas do Ação Centro seguiram claramente esse receituário, como na montagem de sua Agência de Desenvolvimento e na escolha das principais estratégias de reabilitação, que embasaram os Projetos Motores e outras 
intervenções urbanísticas com pretensões de "alavancar" transformações em seu entorno. Em grande parte, a adoção destas estratégias foi determinada pela atuação do BID, indicando experiências que deveriam ser seguidas como exemplos "bem sucedidos" de recuperação de áreas consideradas degradadas, como veremos adiante na seção 3.2. Entre as experiências indicadas pelo banco, destacam-se a de Paris (França), Nova Iorque (Estados Unidos), Londres (Inglaterra) e Barcelona (Espanha), além de Buenos Aires (Argentina).

Alertamos que as duas abordagens de intervenção urbanística - e as experiências correlatas apresentam sobreposições de objetivos e estratégias e não podem ser entendidas de forma rigidamente estanque, principalmente devido à "captura" de discursos da primeira pela segunda, como já destacado anteriormente. Ambas partem do entendimento de que é necessário intervir nas áreas centrais das cidades, na medida em que passaram por processos de esvaziamento e deterioração física; ao mesmo tempo, introduziram novos preceitos urbanísticos a partir dos questionamentos feitos ao movimento moderno. No entanto, a fim de esclarecer seus principais objetivos e estratégias, consideramos adequado separá-las em dois conjuntos, duas abordagens distintas - o que realmente são.

\subsubsection{INTERVENÇÃO NA CIDADE EXISTENTE: PATRIMÔNIO E HABITAÇÃO SOCIAL}

Os princípios urbanísticos de intervir sobre o existente - edificações e áreas urbanas - atentam o para a preservação do patrimônio construído, de seus aspectos morfológicos e tipológicos, bem como do tecido social, dos usos tradicionais e perfis de renda da população moradora e usuária das áreas de intervenção (PORTAS, 1985). Segundo Portas (1985, p.8), isso não significa que "o conceito de intervenção na cidade existente (...) sacralize toda a edificação pelo fato de já existir, mas sim que toma como um dado econômico e cultural a estrutura e forma da cidade, dos seus bairros e centros, dos seus edifícios, ruas e quintais e também como dado um dado social a trama de relações sociais e de atividades que aquelas estruturas físicas suportam e refletem”.

$\mathrm{Na}$ Europa, esse conceito embasou a constituição de metodologias de intervenção urbana focadas na preservação do patrimônio histórico e cultural de forma articulada com políticas de habitação social, baseando-se na participação da sociedade civil e na manutenção da diversidade de classes sociais, usos e funções urbanas. As críticas que vinham sendo feitas ao movimento moderno $^{103}$, relativas aos seus princípios construtivos, de preservação do patrimônio, de

103 Como dito, as críticas aos princípios modernos enfocavam sua forma de atuar sobre o urbano, tecnicista, homogeneizante e descolada da realidade, que buscava organizar o território urbano a partir da funcionalidade e racionalidade moderna. 
planejamento e gestão urbana, fortaleceram o desenvolvimento de ações que buscavam respeitar o tecido urbano e social existente e as especificidades locais, a fim de garantir a permanência dos moradores originais e usos tradicionais nas áreas de intervenção.

A evolução histórica levou os centros degradados das cidades e, eventualmente, as pequenas cidades abandonadas a se tornarem reservas de alojamento barato. Sua restauração deve ser conduzida por um espírito de justiça social e não deve ser acompanhada pelo êxodo de todos os habitantes de condição modesta. (MANIFESTO DE AMSTERDÃ, 1975)

Entre as ações desenvolvidas, a experiência italiana ficou conhecida como Conservação Integrada (CI), tendo se originado no urbanismo reformista italiano das décadas de 1960 e 1970, com coordenação de técnicos ligados ao Partido Comunista Italiano, que permaneceu no poder público municipal da cidade de Bolonha durante esse período, como apontado ${ }^{104}$. Já as experiências francesa e portuguesa foram chamadas de Reabilitação Urbana, sendo que a primeira tomou impulso a partir da década de 1970, fortemente associada à estruturação da política habitacional francesa, e a segunda se constituiu a partir da década de 1980, tendo na cidade de Lisboa seu caso mais significativo, com a ascensão ao poder do Partido Socialista Português em 1989. Todas elas - italiana, portuguesa e francesa - procuravam contrapor-se às ações de Renovação Urbana do pós-guerra, em que se realizava uma substituição de edificações e usos dos bairros centrais através da demolição seguida de reconstrução, acarretando uma especulação e valorização imobiliária (CERVELLATI, 1976; LOPES, 2000; BOUCHE, 2000).

Tal processo de Renovação, necessário para a reconstrução do tecido urbano destruído pelos bombardeios, caracterizou-se de forma diferente em cada cidade; ora marcado por maior preocupação em conservar as edificações históricas existentes, ora realizando demolições inclusive de edificações e áreas que não tinham sido atingidas pela guerra - esse último caso era associado a intenções de mudança nos perfis de uso e dos moradores (LUCINI, 1996). De todo modo, operava-se uma reconstrução segundo a lógica da "terra arrasada", aproveitando algumas edificações abandonadas pelo êxodo de atividades produtivas, mas priorizando a construção nova. Perdiam-se porções consideráveis do patrimônio comum, aquele considerado não monumental, mas que compunha um testemunho e a memória de determinado período histórico das cidades, ao mesmo tempo em que eram expulsos os usos tradicionais e moradores originais, geralmente idosos e de baixa renda. Um considerável aumento da demanda habitacional - em decorrência tanto da expulsão de moradores das áreas centrais renovadas, como de movimentos migratórios - intensificou a produção de conjuntos habitacionais nas periferias, até então

104 Para uma abordagem mais detalhada sobre o urbanismo reformista italiano, com enfoque na cidade de Bolonha, ver Lucini (1996). 
ocupadas por atividades rurais artesanais. Marcava-se uma tendência de expansão periférica das cidades, na qual ocorria um aumento da função terciária e, ao mesmo tempo, a decadência do uso habitacional nos bairros centrais, com o êxodo de moradores para as periferias.

Nesse sentido, tanto a Conservação Integrada quanto a Reabilitação Urbana propunham a reversão dessa tendência de periferização e esvaziamento dos bairros centrais. Ao contrário da Renovação, seu enfoque foi manter a população moradora das áreas que passavam por intervenções, priorizando a recuperação do patrimônio histórico arquitetônico como forma de melhorar a qualidade de vida das populações residentes. Partindo de um olhar estrutural das cidades, sua intenção era evitar as deseconomias urbanas geradas pela expansão periférica, buscando um repovoamento dos bairros centrais - uma "volta à cidade" - o equilíbrio dos gastos sociais e econômicos da produção do espaço urbano, bem como uma mistura de usos que evitasse a segregação funcional.

No caso italiano, esse olhar estrutural contribuiu para uma tentativa de integração entre a recuperação do centro histórico e outras ações setoriais, desde aquelas que procuravam controlar o mercado imobiliário especulativo até as de contenção do uso do transporte individual, vislumbrando uma articulação centro-periferia. Já no caso português, Felipe Lopes, urbanista que coordenou as ações de reabilitação em Lisboa, pela Diretoria Municipal de Reabilitação Urbana, criada em 1990, aponta que:

A reabilitação fixando a população no centro, procura contrabalancear esta tendência [de periferização], reduzindo os fluxos pendulares, a desertificação e conseqüente insegurança do centro, e encorajando a instalação de atividades na periferia, fomentando assim a mistura de funções urbanas em todo o tecido urbano. (LOPES, 1995, p.27)

Os mecanismos e instrumentos urbanísticos criados no âmbito dessas iniciativas, bem como os planos, políticas e programas montados, pressupunham um efetivo controle do Estado sobre a produção do espaço urbano e a canalização de consideráveis aportes públicos - subsídios e financiamentos - para a recuperação de edificações antigas, em especial para aquelas ocupadas por moradores de baixa renda em sistema de locação. Principalmente na experiência francesa, mas presente em todas elas, esses pressupostos envolviam a estruturação institucional, financeira e técnica das ações de intervenção urbana, vinculada aos sistemas nacionais de políticas públicas.

No caso francês, o marco institucional foi a criação da ANAH - Agence Nationale pour l'Amélioration de l'Habitat (Agência Nacional para a Melhoria do Habitat) em 1971 para atuar sobre a habitação privada de aluguel, visando inserir o princípio da recuperação da moradia antiga nas políticas habitacionais, financiando operações de restauração imobiliária e recuperação do patrimônio construído. A partir de sua criação, foram realizados contratos entre o Estado Central 
e as diversas municipalidades, constituindo uma política "radicalmente nova no tratamento da intervenção urbana (...) de novas concepções do urbanismo, da habitação, do patrimônio, monumental e cotidiano, e o âmbito de formação de novas equipes políticas e profissionais" (BOUCHE, 2000, p.10). Também a instituição do instrumento urbanístico da OPAH - Opération Programmée d'Amélioration de l'Habitat (Operação Programada para a Melhoria do Habitat) foi fundamental para a estruturação da reabilitação urbana francesa, implantado até hoje e tendo ocorrido pela primeira vez em 1977. Através deste instrumento, eram cedidos benefícios aos proprietários, em especial aos rendatários/locatários, buscando a melhoria da habitabilidade dos bairros antigos, a valorização do patrimônio, a manutenção da morfologia, da mistura social e de usos existentes e a permanência dos moradores de baixa (COULON, 2000, p.7). Segundo Bouche (2000, p.11), "as OPAH marcam uma virada”, pois com elas passou-se a estimular a iniciativa privada para a realização das intervenções que, portanto, deveriam ser atrativas aos proprietários $^{105}$.

O caso italiano, em especial da cidade de Bolonha, ficou conhecido pela canalização de recursos públicos para os grupos de baixa renda moradores das áreas centrais (LUCINI, 1996) e serviu de base para a elaboração da legislação nacional relativa à recuperação urbana e de edificações. Ao mesmo tempo, a viabilidade da experiência nesta cidade se deu mediante regulamentações federais referentes à aquisição pública de áreas para intervenção e ao aluguel social ("equo cannone"), envolvendo a criação de fundos públicos e a montagem de programas especiais, vinculando a reabilitação ao planejamento urbano do município. Ainda que em numa escala mais local, o mesmo ocorreu na experiência portuguesa, em que foi montado o Programa Nacional de Reabilitação Urbana (PRU) em 1985, posteriormente rebatizado de Programa de Recuperação de Áreas Urbanas Degradadas (PRAUD), também contando com fundos públicos de âmbito nacional.

$\mathrm{Na}$ base da abordagem da "intervenção na cidade existente" está um conceito alargado de patrimônio histórico, que não restringe a preservação ao edifício isolado e monumental, mas inclui as construções "modestas" e de pequeno porte no leque de edificações a serem preservadas. Em conjunto com essas edificações "modestas" deveriam ser considerados os usos, costumes e relações sociais existentes, abarcando manutenção da população moradora. Esse conceito alargado foi apresentado pela primeira vez na Carta de Veneza de 1964 e reiterado em

105 Para uma análise mais pormenorizada da experiência francesa ver Diogo (2004). 
diversas outras Cartas Patrimoniais ${ }^{106}$ desde então, como no Manifesto e na Declaração de Amsterdã de 1975 (Carta Européia do Patrimônio Arquitetônico), em que foram sistematizados os princípios da Conservação Integrada, e na Carta de Lisboa de 1995, essa última sistematizou os conceitos da Reabilitação Urbana portuguesa.

\begin{abstract}
A noção de monumento histórico compreende a criação arquitetônica isolada, bem como o sítio urbano ou rural que dá testemunho de uma civilização particular, de uma evolução significativa ou de um acontecimento histórico. Estende-se não só às grandes criações, mas também às obras modestas, que tenha adquirido, com o tempo, uma significação cultural. (CARTA DE VENEZA, 1964, art. $1^{\circ}$ )

Esse patrimônio compreende não somente as construções isoladas de um valor excepcional e seu entorno, mas também os conjuntos, bairros de cidades e aldeias, que apresentam um interesse histórico ou cultural. (DECLARAÇÃO DE AMSTERDÃ, 1975)
\end{abstract}

O objeto de todas as intervenções se constituía no centro histórico e os bairros centrais em seu conjunto, que passavam a ser entendidos como patrimônio único e integrante da cidade como "artefato histórico-cultural", marcado por uma pluralidade de significados e valores, cujas dimensões cultural, política e econômica deveriam ser valorizadas. Para a idéia de patrimônio que abarcava os edifícios "modestos", considerando o ambiente em que se integravam, foram adotadas diversas terminologias, como "patrimônio banal" no caso francês. (MARICATO 2001; LABHAB/FAUUSP/École Nationale des Ponts at Chaussées/Pact Arim Internacional 2000). Além disso, procurava-se avançar em relação ao tratamento museográfico dos bairros e conjuntos históricos, inserindo-os na dinâmica urbana existente e considerando seu valor de uso e social, como destaca Lopes (2000).

É obvio que um conjunto urbano não pode ser transformado num museu. Ele tem de
continuar a viver e a produzir a mudança social. Porém, as estruturas construídas
dificilmente acompanham as transformações sociais, tornando-se anacrônicas. Então, a
preocupação patrimonial leva-nos a pensar numa preservação de consonâncias estáticas
que se opõem à transformação, que é movimento. E exatamente neste desafio de conciliar
a preservação do patrimônio com a promoção da mudança social que se situa e se defini a
Reabilitaçâo Urbana (LOPES, 2000, p.4). O enfoque sobre o patrimônio histórico - o conceito alargado - abarcando a identidade cultural das áreas de intervenção, esteve presente em todas as experiências analisadas. O Plano de Recuperação do Centro de Bolonha de 1969 colocava-se contrário à substituição de edificações, considerando todos os edifícios históricos dignos de preservação e determinando sua recuperação através da "restauração conservativa", ou seja, uma recuperação tipológica (estrutura, técnicas e materiais construtivos). Em Lisboa, estudos e levantamentos realizados pelos Gabinetes Técnicos Locais (GTL) indicaram que 70\% da população residia a mais de 17 anos em seu respectivo

106 As cartas patrimoniais, como a Carta de Veneza, são documentos relativos à preservação do patrimônio histórico cultural e arquitetônico, resultados de encontros internacionais sobre o tema, tendo como signatários diversos países. Ver Cury (2000). 
bairro, configurando forte enraizamento e identidade cultural, que deveriam ser preservados. No caso da reabilitação francesa, a delimitação dos Setores de Salvaguarda (Lei Malraux de 1962) possibilitou o tratamento patrimonial de conjuntos urbanos, preservando não apenas as edificações de forma isolada, mas também a morfologia das áreas e incluindo aquelas não listadas ou classificadas pelos órgãos de preservação. As ações de recuperação propostas nesses setores eram, em geral, realizadas em conjunto com as OPAH, o que lhes possibilitava maior aporte de recursos financeiros, viabilizando a realização dos Planos Permanentes de Preservação e Valorização de cada setor, de forma associada à produção de moradia popular.

Em todos os casos, a intenção era adaptar as edificações às necessidades da vida contemporânea, fator essencial à produção de habitação social e à manutenção dos moradores originais de baixa renda. De modo geral, as intervenções que buscavam preservar a totalidade das características tipológicas e morfológicas dos conjuntos edificados, não atendiam os parâmetros urbanísticos, construtivos e de habitabilidade contemporâneos. Assim, ao procurar adaptar o patrimônio construído a essas necessidades, enfocando a melhoria das condições de conforto, segurança e habitabilidade das edificações - muitas residências não possuíam sequer banheiro e cozinha tornava-se necessária certa flexibilização das normas urbanísticas e edilícias, bem como dos próprios critérios de preservação.

Pode-se notar essa intenção na experiência francesa, nos critérios de recuperação dos Setores de Salvaguarda, em que eram associados procedimentos urbanísticos, arquitetônicos e de restauração de imóveis (BOUCHE, 2000), com vistas à adaptação das edificações. Destaca-se o caso português, em que foi introduzida a idéia de "intervenção mínima" (LOPES, 2000), priorizando as obras emergenciais e necessárias à adaptação das edificações existentes para atender os parâmetros de habitabilidade, melhorando as condições de vida da população moradora. Tal idéia também foi influenciada pelo contexto de descapitalização dos proprietários - congelamento dos aluguéis - e de falta de capacidade financeira dos inquilinos.

Da mesma forma, o entendimento da recuperação do patrimônio a partir da identificação das tipologias construtivas, aceitava certo grau de alteração das características originais das edificações, inclusive demolições. Mesmo partindo da importância da preservação do patrimônio, essas exceções ocorriam em todas as experiências que analisamos, em especial nos casos de edificações que tinham perdido sua originalidade de tal forma que não era possível reconstruí-las. Esse enfoque foi dado na experiência italiana, que contava com os Programas de Habitação Popular nos bairros centrais, como uma alternativa à produção massiva de novas moradias nas áreas periféricas da cidade e garantindo que as edificações recuperadas fossem adequadas e 
destinadas à habitação social, por meio do controle dos valores de aluguel e da contenção da valorização imobiliária. Esses planos eram associados a uma política de preservação do patrimônio histórico, pautada na identificação de 4 tipologias construtivas existentes - dos grandes monumentos às casas mais modestas - e na definição de 2 níveis de intervenção, de acordo com os diferentes regimes de ocupação e perfis de renda dos ocupantes.

Pode-se dizer, portanto, que o pressuposto metodológico mais significativo da Conservação Integrada e da Reabilitação Urbana repousa sobre a integração entre a preservação do patrimônio construído - de valor histórico ou não - e a produção de habitações sociais. Ao mesmo tempo em que a noção alargada de patrimônio histórico conduzia à preservação física do conjunto de edifícios, inclusive aqueles comuns e cotidianos, previa também a manutenção dos costumes tradicionais e relações sociais, o que garantia a permanência da população moradora de baixa renda e da diversidade de usos nas áreas recuperadas. Como destaca Cervellati (1976, p.3), "a vitalidade (ou a revitalização) do centro histórico está, de fato, extremamente ligada ao direito das classes sociais populares a habitá-lo”.

Seguindo o conceito alargado de patrimônio histórico, a preservação do ambiente construído deveria ocorrer mediante o reconhecimento da cidade existente, de suas características morfológica e tipológica das edificações e das áreas urbanas, considerando as especificidades locais de cada bairro. Segundo Del Rio (1990, p.71), a abordagem morfológica da cidade estuda "o tecido urbano e seus elementos construídos formados através de sua evolução, transformações, inter-relações e dos processos sociais que os geraram". Como aponta Píer Luigi Cervellati, um dos urbanistas idealizadores da experiência de Bolonha:

\footnotetext{
Esta análise morfológica tem permitido esclarecer a relação existente entre a estrutura pequena e fragmentada da parte residencial, e os grandes capítulos arquitetônicos e urbanísticos (elementos emergentes como palácios, conventos, praças, etc.), fundamentando sobre essa relação - a qual configura hoje de maneira concreta a cidade histórica - os critérios básicos para a conservação ativa (CERVELLATI, 1976, p.29, tradução da autora).
}

Nesse sentido, dava-se grande importância à elaboração de diagnósticos, identificando usos e atividades existentes, perfis de renda das famílias moradoras, tipologias edificadas, espaços livres, estrutura viária e fundiária; para posterior definição dos instrumentos que seriam utilizados nas operações de recuperação/preservação. A compreensão das dinâmicas sociais, culturais e econômicas também recebia grande enfoque, o que, em conjunto com a importância dada ao reconhecimento das estruturas físicas, embasava a instituição de uma gestão participativa da recuperação dos bairros centrais. 
No caso italiano de Bolonha foram articulados debates com moradores e proprietários, através da montagem dos Conselhos de Bairro e/ou Setor, sendo que a participação da população ocorria em diversos níveis de gestão e decisão, definindo prioridades e elaborando alternativas de ação. Assim como a canalização de recursos públicos para as camadas de baixa renda, num espírito de justiça social, a gestão urbana participativa e local se tornou uma bandeira política do Partido Comunista Italiano (ZANCHETI, 2003). Também na experiência francesa, a gestão local era realizada, através dos operadores ${ }^{107}$ das $\mathrm{OPAH}$, que assumiam alguns dos serviços públicos e instalavam uma agência local no perímetro de intervenção, a fim de facilitar a proximidade com a população e a realização dos trabalhos de campo - levantamentos, obras, acompanhamento social etc.

Mas foi na experiência portuguesa que a gestão urbana participativa ganhou relevância, através da instalação dos Gabinetes Técnicos Locais (GTLs), que agregavam funções e competências de 4 dos órgãos e diretorias municipais, realizando uma gestão integrada da reabilitação: planejamento das ações, destinação dos recursos, projetos e acompanhamento de obras, elaboração dos planos de preservação, gestão do parque habitacional público, levantamentos sócio-econômicos, assistência e relocação das famílias para as obras. Compostos de profissionais de diversas áreas, os GTLs funcionavam como postos avançados do poder público no território, coordenando as ações de reabilitação e aproximando a estrutura administrativa municipal da população.

Seu principal papel era mediar os conflitos de interesse dos diversos grupos sociais presentes nas áreas de intervenção - setores da construção civil, pequenas construtoras, proprietários, inquilinos, comerciantes, associações de moradores etc. - realizando consultas e tomadas de decisão conjuntas com a população ${ }^{108}$.

Um outro aspecto fundamental da metodologia da "intervenção na cidade existente", presente em todas as experiências analisadas, foi o desenvolvimento de setores do mercado imobiliário voltados ou especializados em reforma, restauro e retrofit de edificações, o que foi possível mediante políticas de âmbito nacional de recuperação de edificações existentes, em especial para uso habitacional. No caso de Bolonha, entendia-se que o estímulo a esses setores como uma atividade econômica do desenvolvimento urbano, contribuiria para o equilíbrio da produção do espaço urbano, diminuindo a construção de novos conjuntos habitacionais nas periferias. Para tal, deveriam ser criados mecanismos de estímulo ao investimento privado - como o direito de

\footnotetext{
107 Em muitos casos, esses operadores são os Pact-Arim - Protection Amélioration Conservation Transformation de l'habitat-Associations de Restauration Immobilière, associações que surgiram nos anos 40 atuando em casos isolados de intervenção em cortiços e reabilitação de edificações, e que estenderam suas ações para a escala do bairro a partir dos anos 60 .

108 Para uma análise mais pormenorizada da atuação dos GTL em Lisboa, ver Padovani (2005).
} 
superfície (CERVELLATI, 1976, p.12) - dando competitividade e vantagens econômicas ao restauro de edificações. Mais ainda, a experiência francesa levou a consolidação de um setor da construção civil voltado para reforma, restauro e retrofit, constituindo-se uma preferência do mercado privado pelas obras de recuperação e adaptação de edificações existentes, em detrimento de construções novas, realizando operações de reabilitação por todo território francês, sem se restringir às áreas centrais.

O lugar da manutenção (reparações pequenas e grandes obras, reabilitação) no setor econômico imobiliário tornou-se superior, nos últimos anos, ao da construção nova, tanto em termos financeiros quanto em termos de emprego. Em 1998, a atividade da construção representava mais de 466 bilhões de francos franceses (ou seja, cerca de 72 bilhões de euros), e a moradia 57,5\% (ou seja, cerca de 41,5 bilhões de euros). Sobre essa última cifra, $57,5 \%$ das obras abrangem a manutenção, e essa porcentagem vem aumentando regularmente. (...) Esse setor beneficia muito particularmente um setor de pequenas empresas e de artesãos, presentes em todo território francês. (BOUCHE, 2000, p.41)

Essa preferência do mercado pela reforma, segundo Bouche (2000), ocorre devido às baixas taxas de juros dos financiamentos, dos grandes montantes de subsídios e dos incentivos fiscais. Como dito, em todas as experiências, em especial na francesa, foram criados sistemas e políticas habitacionais que envolviam modalidades de financiamento e subsídios destinadas prioritariamente para a moradia de aluguel, localizadas em áreas e bairros preservados. No caso francês, duas modalidades merecem destaque: a primeira trata-se de edificações preservadas, em Setores Salvaguardados ou Zonas de Proteção, permitindo valor de financiamento maior; e a segunda enfoca intervenções em moradias sociais, concedendo um subsídio maior, que pode variar entre $25 \%$ e $70 \%$ do custo total da obra, quando o proprietário se compromete a praticar um aluguel moderado para famílias de baixa renda, nos moldes da locação social pública, ou para famílias indicadas pelo Estado. Vê-se que o aporte de recursos públicos era (e continua sendo) considerável e o controle do Estado sobre a produção privada de moradia social é efetivo limitação dos valores dos aluguéis que devem ser cobrados como condição para concessão de maiores subsídios.

Além disso, a intervenção de melhoria em moradias existentes passou a representar um custo menor em relação à produção de moradias novas (BOUCHE, 2000; COULON, 2000). Esse aspecto é apresentado por Lopes (2000) para o caso português, destacando também a economia urbana que a modalidade de reforma propicia, evitando: a terceirização dos centros urbanos; a destruição da diversidade do tecido social; do patrimônio e do ambiente urbano; a periferização da população; os fluxos pendulares periferia-centro-periferia; a necessidade de implantar infraestrutura nas periferias e a marginalidade social.

O valor médio de intervenção por alojamento é de 3.178 contos, dos quais 1.980 contos de fundos públicos, ou seja, menos da metade do custo dum alojamento social novo e um 
quarto do custo em fundos públicos. Se tivermos em consideração que a população em causa, se não lhe for solucionado o seu problema, será candidata a um alojamento social, é obvia a vantagem econômica da opção reabilitação, a que deverá, ainda, acrescentar-se a economia do terreno e das infra-estruturas existentes. (LOPES, 1995, p.29).

Nas experiências italianas, portuguesas e francesas, os bairros centrais, marcados pela presença de edificações antigas ocupadas por moradores de baixa renda, tornaram-se focos de programas habitacionais e de recuperação do patrimônio histórico. Os mecanismos implantados possibilitavam recuperar as edificações existentes e, ao mesmo tempo, melhorar a qualidade de vida dos bairros, mantendo os aspectos morfológicos e tipológicos do tecido urbano, e o perfil da população moradora e usuária, seus hábitos, costumes e relações, fortalecendo sua identidade cultural e social. Ao mesmo tempo, vimos que todas essas experiências estiveram associadas a um modelo de desenvolvimento urbano pautado no efetivo controle do poder público sobre a produção do espaço urbano, em que incentivos a setores do mercado privado eram concedidos mediante condições que garantissem o interesse coletivo.

No entanto, isso não significa em que tais experiências deixaram de realizar demolições e substituições de edificações velhas por novas/modernas, nem que conseguiram evitar por completo a expulsão da população de baixa renda das áreas recuperadas e seu assentamento em conjuntos habitacionais periféricos. Após as primeiras décadas de implementação, fatores como o desenvolvimento de atividades terciárias e turísticas, o corte de recursos públicos, mudanças políticas de governos, entre outros, aumentaram o processo expulsão da população de baixa renda das áreas recuperadas, que sofriam forte valorização imobiliária. Como destaca Zancheti (2003, p.99), certo grau de "gentrificação" passou a ser aceito pela municipalidade de Bolonha, entendido como inevitável, especialmente a partir do enfraquecimento do Partido Comunista Italiano no governo municipal na década de 1990.

$\mathrm{Na}$ França, algumas críticas também mostraram alguns bairros reabilitados tinham sido transformados em "bairros museus" ou "guetos de ricos" (PERRIN, 1980), como o caso do Marais em Paris, resultado da expulsão de moradores de baixa renda. Nesta cidade, também há que se destacar a aplicação conjunta das OPAH com as ZACs - Zones d'Aménagement Concerté (Zonas de Planejamento Consertado), cujo objetivo é atrair a instalação de novos usos e atividades a partir da realização de obras públicas. Tal associação, segundo Coloun (2000, p.7), pretende integrara a organização de uma zona estratégica (ZAC) e a reabilitação da parte antiga desta zona (OPAH). No entanto, a aplicação das ZACs tem servido para a constituição de “distritos de negócios” à imagem da "cidade-global”, como em La Défense.

No caso de Lisboa, a reabilitação não foi interrompida por completo, porém sofreu cortes de recursos e alterações a partir de meados dos anos 90. Os GTLs e a Direção Municipal de 
Reabilitação Urbana tiveram seu campo de atuação reduzido depois das eleições municipais de 2002 (PADOVANI, 2005), refletindo a perda de importância do processo de reabilitação dentro da agenda as ações municipais e do governo central. Apesar de ser entendida como referência para futuras ações de Reabilitação Urbana - como foi no caso paulistano (PADOVANI, 2005) tendo obtido relativo sucesso em relação aos seus objetivos, a capital portuguesa também realizou ações pautadas nos princípios do planejamento estratégico. Tais princípios marcaram as intervenções numa antiga área industrial nas margens do rio Tejo, com vistas a abrigar a EXPO 98 (Parque das Nações) e a EXPO URBE. Foi o que Zancheti (2003) chamou de "abordagem heterodoxa".

Nos anos 90 foi elaborado o Plano Estratégico de Lisboa, impulsionado por sua vontade e necessidade de se projetar dentro da Comunidade Européia, com base no slogan "Lisboa: Capital Atlântica da Europa". A construção de uma imagem pós-moderna e a reafirmação de sua identidade cultural eram entendidas como elementos necessários para colocar a cidade em condições de competir por capitais no circuito das "cidades-globais", apoiando-se no fato de ter sido declarada capital cultural européia em 1994. Um rol de projetos "alavanca" e o apelo de sua frente marítima - oceanário, passeio de orla, teleférico, shopping center, torres de estética bigh tech na ocasião da EXPO URBE, foram alguns dos mecanismos utilizados para lançar a cidade neste circuito, possibilitando parcerias com o capital privado.

\subsubsection{Gestão URBANA EMPRESARIAL: PlanejAMENTO ESTRATÉgico E “CITY}

\section{MARKETING"}

No contexto da crise de acumulação a que nos referimos anteriormente, em que se desenrolaram a "reestruturação produtiva" (HARVEY, 1992) e as teorizações sobre as "cidades-globais" (SASSEN, 1998), surgiam as experiências de renovação e revitalização urbana ocorridas nos países do norte, pautadas nas técnicas do planejamento estratégico e do "city marketing”. Elas foram difundidas como práticas urbanísticas adequadas ao atual "protagonismo" das cidades (CASTELLS \& BORJA, 1996), transferindo as idéias empresariais para o gerenciamento urbano $^{109}$ voltado para a competição de mercado, vendendo localizações vantajosas para os negócios "globalizados".

109 Originado na prática militar, o pensamento estratégico foi transferido para a esfera empresarial a partir de meados do século XX (FERREIRA, 2007; ARANTES, 2000), e depois para a gestão urbana. Para essa última passagem e sua difusão como prática urbanística "bem sucedida", os organismos multilaterais foram agentes chaves, como veremos na próxima seção. 
Enquanto as propostas da chamada "nova esquerda", que surgiram na esteira das revoltas do final dos anos 1960, pressupunham uma considerável intervenção estatal sobre o espaço urbano, garantindo acessos e direitos à população de baixa renda, o discurso do planejamento estratégico passou a defender que o Estado deveria minimizar seus gastos nos projetos de intervenção urbana, buscando parcerias com a iniciativa privada e diminuindo sua parcela de investimentos, no bojo da lógica neoliberal. No entanto, e embora não se comente tanto, a participação do Estado nesses processos de (re)produção do espaço urbano foi fundamental para a efetivação das estratégias propostas. Como aponta Deák (2001), o papel do Estado sempre foi necessário, inclusive para implementar os preceitos da ideologia neoliberal (FERREIRA, 2007, p.113), o que nos leva a considerar que sua propalada retirada, de fato, não tem ocorrido.

Pelo contrário, no caso dos países industrializados, que não foram coagidos a adotar a cartilha neoliberal do "Consenso de Washington", a participação estatal chegou até a se intensificar nas últimas décadas. Contradizendo Castells, para quem "os mercados globalizados e informatizados já não necessitam do Estado como foi o caso ao longo de toda a historia da humanidade" (Castells 1998:8), em 2001 os principais países da social-democracia européia continuavam a engajar uma quota considerável de seus PIBs em gastos públicos: 46,2\% na França, 41,9\% na Itália, 36,4\% no Reino Unido. (FERREIRA, 2007, p.113, grifos no original)

Ainda assim, seguindo o discurso da perda de capacidade do poder público em controlar e investir na produção do espaço urbano - num contexto de crise do sistema keynesiano de BemEstar Social - foram realizadas diversas intervenções urbanas que buscaram adequar as cidades ao seu novo papel dentro da atual etapa de acumulação de capital. De acordo com as hipóteses da “cidade-global” (SASSEN, 1998; CASTELLS \& BORJA, 1996), em que as grandes cidades se tornaram a expressão espacial da nova ordem econômica mundial financeirizada, as cidades não deveriam ser entendidas como cidades, mas sim como empresas, o que condiz com a idéia de retirada do Estado.

Entre essas intervenções se destacam aquelas que pretenderam recuperar áreas urbanas que passaram pelos típicos processos de obsolescência - decorrentes da reestruturação produtiva (HARVEY, 1992) - abandono e degradação, concomitantes às transformações de ordem econômica, observadas a partir da crise do sistema de acumulação fordista. Centros históricos, antigas áreas portuárias e bairros centrais foram focos de projetos de recuperação urbana e retomada econômica, tendo como base o receituário do planejamento estratégico, a exemplo das áreas portuárias e industriais de Baltimore e Boston, nos Estados Unidos, de Londres na Inglaterra e, numa segunda fase, de Barcelona, na Espanha.

Nesses casos, o poder público deveria ter papel de articulador e fomentador da livre iniciativa sobre a produção do espaço urbano, em geral através da criação de instâncias de gestão mais flexíveis do que os tradicionais órgãos da administração pública - corporações, agências, 
empresas públicas ou mistas, etc. - "azeitando a máquina urbana de crescimento" (ARANTES, 2000; FERNANDES, 2001; FERREIRA, 2007), numa busca pelo crescimento urbano "a qualquer custo". Isso ocorreu em inúmeras experiências de revitalização urbana, sendo o caso de Battery Park City em Nova Iorque um dos pioneiros, com a Battery Park City Authority (BPCA) em 1968. A difundida experiência de Barcelona contou com a Sociedade Privada Municipal Vila Olímpica S.A. (VOSA) de 1986, a Barcelona Holding Olímpica de 1989, e mais recentemente a 22@BNC S.A.; essa última criada para viabilizar o projeto de desenvolvimento de um pólo tecnológico na região de Poble Nou, antiga área industrial que já havia sido foco de projetos na época das Olimpíadas de 1992.

Diante do quadro de decadência dessas áreas, pretendia-se redinamizar sua economia local e valorizar seus imóveis - a superação da crise - através da atração de capital privado, instalando novos estabelecimentos comerciais e de serviços, de preferência aqueles ligados a nova lógica de acumulação financeira: telecomunicações, informática, consultoria a empresas, publicidade, contabilidade, entre outros dentro dos setores terciário "avançado" ou "moderno". Procurava-se incentivar usos mais rentáveis do que os originais, justificando tal estratégia pelo crescimento econômico e pelos novos postos de empregos que seriam gerados.

Para viabilizar essa atração de capitais, a receita propagada era a desregulação dos mecanismos de controle sobre a produção do espaço urbano, flexibilizando os parâmetros urbanísticos e criando incentivos aos investimentos imobiliários. Cidades passaram a praticar isenção de impostos e taxas, liberação quanto à aprovação de determinados empreendimentos e eliminação dos limites para construção (coeficientes de aproveitamento, gabaritos, etc.). Diversos instrumentos urbanísticos foram implantados com esse fim, como as ZACs francesas (Zones d'Aménagement Concerté) e as EZs inglesas (Enterprise Zones); a primeira foi aplicada, por exemplo, nas regiões parisienses de La Défense e Rive le Gouche, e a segunda aplicada a partir de 1982 no caso das Docklands londrinas, especificamente na região de Canary Wharf, após a ascensão do governo de Margareth Thatcher, que implantou uma reformulação da política urbana inglesa, marcadamente de cunho neoliberal (NOBRE, 2000).

Atrair investimentos privados como meio de recuperar uma área urbana decadente é pressuposto central do receituário do planejamento estratégico, apresentado como "fórmula de salvação" das cidades contemporâneas diante de sua necessária adaptação à nova fase da economia "global" (FERREIRA, 2007), marcada pela escassez de recursos públicos. Segundo seus defensores, essa estratégia se constitui de projetos ou intervenções pontuais, capazes de gerar uma reação em 
cadeia de recuperação e dinamização econômica em seu entorno, alcançando um "efeito sinérgico".

Curioso atentar para o fato de que esses projetos contaram, invariavelmente, com consideráveis montantes de recursos ou subsídios públicos, na maioria das vezes realizando obras de instalação ou melhoria da infra-estrutura, ou ainda, repassando terrenos para a iniciativa privada. Ainda que o ideário do planejamento estratégico defenda a diminuição dos gastos públicos e do papel do Estado no controle da produção do espaço urbano, as operações de recuperação de áreas urbanas consideradas degradadas que seguiram seu receituário necessitaram de ações e investimentos públicos para "alavancar" os investimentos privados. Como apontam os idealizadores ${ }^{110}$ dos projetos de Barcelona para as Olimpíadas de 1992, a empresa de capital misto VOSA criada para promover as transformações na cidade para o evento, se responsabilizou pela execução da infraestrutura e preparação para a construção dos edifícios (MARTORELL et al., 1991, apud SOUZA 2007).

Este aspecto foi marcante nas Docklands londrinas, na medida em que, até a virada dos anos $80 \mathrm{e}$ 90, os empreendimentos de Canary Wharf não tinham sido "alavancados" devido à insuficiência da infra-estrutura viária e de transportes. A incorporadora responsável pelo empreendimento Olympia \& York Properties (O\&Y) - propôs então a construção de uma nova linha de metrô e uma série de melhorias viárias, sendo que $80 \%$ do valor das obras foi custeado pela London Docklands Development Corporation (LDDC), a corporação de desenvolvimento das docas (NOBRE, 2000).

A idéia é que as cidades devem necessariamente seguir as difundidas "receitas de sucesso" para que alcancem o status de "cidade-global" e se tornem aptas a competir por investimentos privados estrangeiros, inserindo-se nos atuais circuitos do capital - caso contrário, estariam fadadas ao fracasso, à estagnação e à obsolescência. Esse receituário, associado diretamente à difusão do ideário econômico neoliberal que orientou o Consenso de Washington (1989) - aliás, difundido pelos organismos multilaterais como o BID e o Banco Mundial - consolidou uma forma de gestão considerada adequada aos necessários ajustes econômicos e urbanos. Como apontam dois dos idealizadores destas receitas de sucesso:

O governo local deve promover a cidade para o exterior, desenvolvendo uma imagem forte e positiva apoiada numa oferta de infra-estruturas e de serviços (comunicações, serviços econômicos, oferta cultural, segurança, etc.) que exerçam a atração de investidores, visitantes e usuários solventes à cidade e que facilitem suas "exportações" (bens e serviços, de seus profissionais, etc.). (CASTELLS \& BORJA, 1996, p.160)

\footnotetext{
${ }^{110}$ Entre eles, Oriol Bohigas, Jordi Borja, Joan Busquets, Manuel Herce e Manuel de Solá-Morales.
} 
Como aponta Vainer (2000, p.76), “a nova questão urbana teria, agora, como nexo central a problemática da competitividade urbana". Além da desregulação dos mecanismos de controle da acumulação de capital e da flexibilização das legislações trabalhistas, urbanísticas, ambientais etc., a competição com outras cidades pela atração de investimentos exigia também a criação de uma imagem urbana "global”, como integrante de um "ambiente favorável” aos negócios.

Uma paisagem urbana pós-moderna dos "novos distritos de negócios", marcada por edifícios inteligentes e de estética high tech, onde a pobreza não é permitida. Ainda segundo Vainer (2000), citando os urbanistas catalães Jordi Borja e Manuel Castells (1997, p.133) - ícones da difusão das técnicas do planejamento estratégico - "a pobreza urbana e a marginalização" são parte de um "entorno social" e "condicionam ou influem consideravelmente nas decisões dos agentes econômicos, na atratividade da cidade".

A transfiguração da pobreza em ambiente foi explicitamente formulada pelos catalães,
quando incluíram no que chamam de entorno social "o peso da pobreza". Os pobres são
entorno ou ambiente pela simples razão de que não se constituem, nem os autóctones, nem os
virtuais imigrantes, em demanda solvável. Em todos os níveis, tanto do ponto de vista
concreto (infra-estruturas, subsídios, favores fiscais, apoios institucionais e financeiros de
todos os tipos) quanto do ponto de vista da imagem, não resta dúvida: a mercadoria-cidade
tem um público consumidor muito específico e qualificado. (VAINER, 2000, p.82, grifos
no original)

Nesse sentido, se buscava atrair não apenas o capital internacional, mas também "visitantes e usuários solváveis", ou seja, moradores e freqüentadores de maior poder aquisitivo, o que, por sua vez, contribui para a instalação e desenvolvimento de atividades econômicas de padrão elevado e maior valor agregado. No caso das Docklands londrinas, além da criação de "novos distritos de negócios", também foram transformados antigos armazéns em lofts, residências de alto padrão, num estilo de vida contemporâneo, destinadas a "jovens executivos de sucesso". Dados da DDC, o Comitê Consultivo das Docklands, criado para assessorar a LDDC e analisar os impactos dos empreendimentos realizados, destaca que houve uma valorização imobiliária de surpreendentes 500\% dos apartamentos de dois dormitórios entre 1984 e 1987, numa área historicamente de classe operária (NOBRE, 2000, p.124).

Também no caso de Battery Park City em Nova Iorque, a execução do centro empresarial (World Financial Center) em conjunto com os projetos da Promenade e do Winter Garden, geraram uma mudança no perfil dos freqüentadores, com uma animação e uma diversidade artificiais, em que foram expulsas as classes sociais “indesejadas” (FAINSTAIN 1991, apud NOBRE, 2000, p. 107). Da mesma forma, a preparação da cidade de Barcelona para receber os jogos olímpicos de 1992, bem como as iniciativas para recuperação de diversos bairros após as olimpíadas, como o próprio 
centro histórico (Ciutat Vella), também gerou processos de valorização imobiliária e "gentrificação".

Em Barcelona, foi o governo municipal quem criou as condições para que as empresas imobiliárias reinvestissem (...). Depois de um período de investimento público, os agentes econômicos se puseram a investir no setor e o preço das habitações não parou de subir desde 1992, signo evidente da revalorização daquela zona. Outros fatores, como o crescimento do turismo depois dos Jogos Olímpicos de 1992, também contribuíram para essa revalorização econômica (...) (CLAVER, 2006, p.157)

Um outro ponto a ser destacado é que essas operações também se pautaram na idéia de participação da sociedade civil e de atenção à cultura e às especificidades locais. Aparentemente de forma contraditória com o que foi exposto até agora, se defende uma gestão participativa, envolvendo os diversos atores locais e buscando a realização de projetos que prezem pela diversidade e pluralidade econômica, de usos, funções e classes sociais.

No entanto, a apropriação que se fez dessas idéias - com teor de "inovação democrática" serviu mais para a criação de (falsos) consensos, necessários para legitimar e viabilizar os projetos de revitalização urbana, escondendo os conflitos e, portanto, anulando qualquer possibilidade de "mistura" ou diversidade. Ou ainda, escondendo os objetivos de "gentrificação" dos projetos de revitalização urbana (BIDOU-ZACHARIASEN, 2006). Segundo Castells \& Borja (1996), a unificação de todos os atores sociais em torno de um projeto estratégico - uma agenda comum deve se pautar numa "sensação coletiva de crise" e na constituição de um "patriotismo de cidades", uma “coesão cívica”; idéia essa já analisada e criticada por Vainer (2000).

Para tal, a realização de grandes eventos internacionais - as Olimpíadas, a Copa, uma Feira ou Exposição Universal - funciona como mecanismo de fortalecimento de uma identidade de cidade (FERREIRA, 2007) e, portanto, de criação dos consensos entorno dos projetos que a lançariam na rede de competição "global". Vale lembrar do papel fundamental do "cultural" a que se refere Arantes (2000), para a consolidação das estratégias neoliberais de intervenção urbana, inclusive para a criação dos consensos: a identidade da cidade - sua cultura - valorizada por grandes eventos ou projetos culturais - entretenimento e consumo - fortalecendo sua inserção na rede de "cidades-globais".

\footnotetext{
Ao mesmo tempo, é justamente isto que diferencia o caráter gerencial do novo planejamento urbano de que estamos falando desde o início; vive-se à espreita de ocasiões... para fazer negócios! (...) Esses Grandes Eventos que em princípio demarcam um pólo de reconhecimento coletivo (e não estou dizendo que não logrem isso, só que num outro registro) perderam qualquer significado intrínseco, a única coisa que realmente importa é saber se estão em condição de movimentar milhares de pessoas e se permitem ou não construir centenas de milhões de metros cúbicos (...) (ARANTES, 2000, p.63)
}

A idéia de "liderança compartilhada" (CASTELLS \& BORJA, 1996) - ou "governança" - que pressupõe um enfoque no poder local e as parcerias público-privadas para a realização dos 
projetos urbanos estratégicos, ao invés de permitir uma gestão urbana realmente democrática e distributiva, reforça o papel do Estado de beneficiar interesses e ganhos privados do grande capital no processo de produção do espaço urbano. Papel esse que não é algo novo e o transforma em instrumento de dominação de classe, como já apontado por diversos autores (LEFEBVRE, 1999; HARVEY, 2005; VILLAÇA, 2001), ainda que contraditório, ambíguo e em constante processo de transformação (HARVEY, 2005).

Dessa forma, investindo consideráveis montantes de recursos públicos para melhorar a infraestrutura e o ambiente urbano de modo geral, os poderes públicos locais têm buscado "alavancar" operações imobiliárias que pretendem retomar o crescimento econômico de determinada área. Em outras palavras, o planejamento estratégico tem viabilizado ganhos privados a partir de investimentos públicos, se consolidando como uma "gestão urbana empresarial de matriz norte-americana" (ARANTES, 2000).

Uma das cidades pioneiras na adoção das técnicas do planejamento estratégico foi Baltimore, na costa leste dos Estados Unidos, cujas iniciativas de recuperação das antigas áreas centrais e portuárias tiveram início nos anos 1960, com um plano diretor proposto pelo empresariado (1957) e encampado pela Prefeitura, incluindo um projeto-piloto de renovação da área central e programas de revitalização (DEL RIO, 1990, p.61). A montagem de empresas de capital misto, especialmente para a realização dos projetos, permitiu agilizar o alcance dos objetivos de retomada econômica e revitalização urbana, com atração de novos moradores de maior poder aquisitivo e instalação de usos recreacionais e turísticos (marinas, shopping centers, aquários públicos, etc.). Como relata Vicente Del Rio (1990, p.63), "é importante ressaltar que um dos fatores essenciais é a participação do empresariado, mormente o comercial, na definição de atrativos-âncora para o consumo, como os haborplaces".

\footnotetext{
Entre os diversos fatores essenciais para o sucesso, pode-se destacar o interesse do grupo empresarial local, o espírito empresarial da Prefeitura, a conjunção de esforços entre o setor público e privado, e a qualidade do programa e do projeto de renovação. (DEL RIO, 1990, p.146)

A implementação da revitalização da cidade e de seu centro permitiu que Baltimore transformasse a sua imagem de decadente e feia; atualmente oferece alta qualidade físicoespacial, um forte setor de comércio e serviços, e uma animada e atrativa mistura de usos recreativos, tornando-a um atrativo turístico regional e nacional. Em Inner Harbor, por exemplo, um conjunto de empreendimentos e atividades variadas garante que esta área renovada atraia uma totalidade estimada de usuários superior a Disneylândia. (DEL RIO, 1990, p.146, grifos nossos)
}

Mas foi com a grande Feira de Baltimore de 1970 - depois tornada anual - que as iniciativas de gestão urbana empresarial ganharam força, seguindo a estratégia de realizar um grande evento internacional como meio para fortalecer a identidade cultural da cidade. Nas palavras de Arantes 
(2000, p.11), "assim surgiu a Baltimore City Fair como forma de promover o redesenvolvimento urbano, celebrando a "vizinhança" e a diversidade étnica da cidade", porém, sem cuidar da "pobreza e demais déficits sociais".

Diversas cidades norte-americanas, como Boston e Washington, experimentaram receitas semelhantes de intervenção em suas antigas áreas centrais e portuárias, com os projetos do “waterfront" e do Quincy Market na primeira, e a constituição de uma empresa de capital misto na segunda, visando recuperar uma importante avenida que se encontrava "decadente" - a Pennsylvania Avenue Development Corporation (1972). Outros casos abordados aqui - europeus e norte-americanos - também foram paradigmáticos dos preceitos da gestão urbana empresarial, sendo que os projetos para as Olimpíadas de 1992 constituíram-se no "modelo Barcelona" (SEGRE, 2004), a experiência mais difundida, principalmente na América Latina.

Difundidas como modelos de recuperação de áreas urbanas consideradas "decadentes" e “degradadas" essas experiências consolidaram o receituário do Planejamento Estratégico como a "fórmula de salvação" das cidades frente à nova ordem econômica mundial - a única forma possível de salvá-las da crise. O caso de Puerto Madero em Buenos Aires, desenrolado ao longo da década de 1990, é um dos exemplos latino-americanos que seguiu tal receituário, estabelecendo parceria/consultoria com a municipalidade de Barcelona e os urbanistas catalães.

Nesta cidade, a criação da Corporación Antiguo Puerto Madero S.A. em 1989 foi fundamental para o agenciamento da operação de revitalização da antiga área portuária da cidade, tendo se tornado proprietária dos galpões existentes, repassando os terrenos para a iniciativa privada e realizado as obras de melhoria da infra-estrutura e dos espaços públicos. Construiu-se um ambiente favorável aos negócios privados, a partir de um considerável aporte de recursos públicos - de acordo com os preceitos do planejamento estratégico - com vistas à "converter esse lugar numa oportunidade de investimentos para o agonizante setor imobiliário" (GARAY, 2001).

No Brasil, a montagem do "Plano Estratégico da Cidade do Rio de Janeiro", discutida por Vainer (2000), e o "Projeto Eixo Tamanduateî" em Santo André no ABCD paulista, tiveram orientação e consultoria dos mesmos urbanistas catalães, especialmente Jordi Borja. Esse último seguiu o modelo do planejamento estratégico para intervenção e recuperação de áreas urbanas "degradadas", especificamente uma antiga área industrial ao longo do eixo da ferrovia (SantosJundiaî). Pautou-se nas estratégias da realização de "projetos-âncora" e de atração de investimentos privados como forma de recuperação urbana e implementou uma instância de “gestão compartilhada" - a Agência de Desenvolvimento do ABC - que, inclusive, serviu de 
referência direta para a montagem da Agência de Desenvolvimento do Centro de São Paulo no âmbito do financiamento do BID, objeto de nossa pesquisa.

Uma importação de idéias, referências e princípios que vem norteando as iniciativas de recuperação da área central de São Paulo, também considerada "decadente" e "degradada", como visto no capítulo anterior. Considera-se a falência dos paradigmas modernos de planejamento urbano, a crise fiscal e de controle do poder público sobre a produção do espaço urbano e a necessária realização de parcerias público-privadas, a partir de um discurso que acredita na consolidação de São Paulo como metrópole terciária e em sua inserção na "rede de cidadesglobais". No entanto, a introdução dessas estratégias tem se mostrado "fatais" para a realidade urbana brasileira, produzida de forma desigual e excludente, tanto ou mais avassaladoras do que em seus países de origem, como já mostraram os estudos que enfocam o desenvolvimento da centralidade terciária nas margens do Rio Pinheiros (NOBRE, 2000; FIX, 2007; FERREIRA, 2007).

Como veremos na próxima seção, muitas dessas experiências de gestão urbana empresarial foram indicadas pelo BID como "exemplos a serem seguidos" para a implantação do programa de recuperação do centro da cidade de São Paulo: Nova Iorque, Londres, Paris e, especialmente e Barcelona (BID, 2004a). Diversas estratégias de intervenção em áreas urbanas consideradas degradadas, que se embasam nos princípios do planejamento estratégico, estiveram presentes no escopo do Programa Ação Centro.

\subsection{CARTILHA do BID PARA A RECUPERAÇÃo DE ÁREAS CENTRAIS}

Como já apontado por pesquisas que se debruçaram sobre as "cartilhas" dos bancos multilaterais para as cidades, a quantidade de material discursivo produzido pelo Banco Interamericano de Desenvolvimento (BID) é comparativamente menor em relação ao Banco Mundial (BIRD). Há poucos documentos conclusivos ou paradigmáticos das receitas urbanísticas, fiscais e de gestão seguidas pelo BID para projetos urbanos - e especificamente para recuperação de áreas centrais. Ainda assim, essas pesquisas mostraram que as estratégias defendidas pelo primeiro seguem os mesmos modelos do segundo (ARANTES, 2004), inclusive na difusão de "boas práticas" ("best practices") e modelos de cunho neoliberal para a gestão da ação pública.

Dessa forma, nessa seção utilizamos como referencial teórico a pesquisa elaborada por Pedro Arantes (2004) sobre as políticas para as cidades latino-americanas, especificamente São Paulo, empreendidas pelos bancos multilaterais, e a publicação dos papers apresentados em Barcelona, no 
"Simpósio de Boas Práticas em Gestão Urbana na América Latina e Caribe”, organizado pelo BID em 1997. Desse último material, destacamos os textos referentes à "revitalização urbana", em especial aquele de autoria de Eduardo Rojas (1998), especialista sênior em desenvolvimento urbano do banco.

Nossa intenção é identificar quais os elementos condicionantes, recomendados ou impostos pelo BID que determinaram algumas - a maioria (?) - das estratégias do Programa Ação Centro de recuperação da área central de São Paulo. Seus princípios foram amplamente moldados por esses elementos que, no limite, eram expressos pelas exigências contratuais do empréstimo. Ao longo do texto, elencamos alguns dos modelos e estratégias defendidos pelo banco e como se deu sua inserção no programa paulistano, apontando os principais embates e concordâncias que ocorreram durante as negociações entre banco e Prefeitura no período de 2002 a 2004. As entrevistas realizadas com alguns dos gestores públicos envolvidos com o financiamento também elucidaram essas questões.

Antes de analisar os padrões e modelos do BID, que determinaram o programa Ação Centro, consideramos necessário abordar brevemente a natureza dos organismos multilaterais e seu papel na reprodução do sistema econômico vigente. Não aprofundamos essa análise, apenas pontuamos algumas passagens a fim de compor o contexto em que o programa para o centro de São Paulo foi montado.

\subsubsection{O PAPEL DOS ORGANISMOS MULTILATERAIS}

Os organismos multilaterais que conhecemos hoje - Fundo Monetário Internacional, Banco Mundial e Organização Mundial do Comércio, entre outros - surgiram no pós-guerra (na Conferência de Bretton Woods), em consonância com a ordem capitalista mundial de liderança norte-americana. A partir da pesquisa de Arantes (2004), pudemos identificar que seu principal objetivo tem sido, desde então, socorrer as crises inerentes ao sistema capitalista e criar um “ambiente favorável” para a reprodução do capital, enfocando o estabelecimento de um "padrão de desenvolvimento para os países do terceiro mundo (...) e a construção de sociedades estáveis na periferia e semiperiferia, de modo que não conduzam o sistema ao colapso" (ARANTES, 2004, p.18). O mesmo princípio de equilíbrio e sobrevivência do sistema vigente se aplica ao BID, criado em 1959, com o propósito de financiar projetos (viáveis) de desenvolvimento econômico, social e institucional na América Latina e Caribe. Seus proprietários são 47 estados membros (com capital no banco), entre aqueles não mutuários (16 países europeus, Israel, EUA, 
Canadá, Japão e Coréia do Sul) e os 26 mutuários (América Latina e Caribe). O Brasil é um de seus principais tomadores de empréstimos.

Seus financiamentos, portanto, englobavam desde ações de "combate à pobreza", de reforma social e atendimento a necessidades básicas, até programas de desenvolvimento, de incentivos à expansão do livre mercado e de apoio a regimes políticos ditatoriais; esse último visando conter o avanço do comunismo no contexto da Guerra Fria. No caso da América Latina, foi criada em 1961 a "Aliança para o Progresso", com vistas a alcançar um crescimento de renda per capita de $2 \%$ ao ano.

Com a crise financeira dos anos 80 - decorrente da crise do petróleo e da política do "dólar forte" - os países tomadores de empréstimos do terceiro mundo sentiram a multiplicação de suas dívidas, o corte dos financiamentos e a incapacidade de pagamento (insolvência), levando os organismos multilaterais a impor um pacote de ajustes com reestruturações financeiras e institucionais. O Banco Mundial e o BID se tornaram os garantidores do pagamento da dívida desses países e, portanto, seus principais credores - uma das únicas alternativas de recursos, diante do fechamento do mercado internacional de crédito (MOURA \& MELO, 1990, apud ARANTES, 2004, p.51) ${ }^{111}$.

Mas os empréstimos voltados ao ajuste vinham associados a obrigações que deveriam ser cumpridas pelos países tomadores, afetando suas políticas econômicas e sociais com reformas “pró-mercado" (ARANTES, 2004, p.52). Deveriam ser cortados os custos, reduzindo os gastos sociais - especialmente os programas de "combate à pobreza" - e criando condições de pagamento da dívida; medidas e determinações de cunho neoliberal que posteriormente foram incorporadas no Consenso de Washington (1989).

A partir de meados dos anos 1990, num contexto em que se buscava "mais consensos e menos coerções", o tema do "combate à pobreza" retornou à agenda do Banco Mundial e novos pacotes de ajustes foram lançados, uma vez que o ajuste anterior "produzia estagnação econômica e impactos sociais negativos" (ARANTES, 2004, p.24).

Quanto às políticas para as cidades - saneamento, habitação, transportes, desenvolvimento e meio ambiente urbanos - Arantes (2004) mostra que representam 14\% do total de empréstimos do BID e do Banco Mundial para a América Latina (valores de janeiro de 2004), tendo sido o BID pioneiro nesse tipo de financiamento. Apesar de apontar a existência de diversas fases

111 MOURA, Alexandrina; MELO, Marcus André. "Políticas públicas urbanas no Brasil: uma análise dos projetos do Banco Mundial”. Revista Planejamento e Politicas Públicas, n.4, p. 99-129. Brasília: IPEA, 1990. 
dessas políticas, com mudanças discursivas e estratégicas, o autor afirma que há "uma linha programática duradoura", condizente aos objetivos de equilíbrio e sobrevivência do sistema capitalista apontados acima, na contenção do comunismo e, depois, na expansão do livre mercado. Resumidamente, podemos explicar essas fases da forma que se segue.

Antes dos ajustes da década de 1980, as instituições multilaterais defenderam e financiaram programas de "urbanização de baixos padrões" e a "auto-ajuda" ("self-help”), que no caso do BID ocorreu através da "Aliança para o Progresso". Projetos de recuperação de áreas centrais históricas se restringiam à preservação do patrimônio, entendendo-o como infra-estrutura para o turismo (KARA-JOSÉ, 2007). A partir dos anos 80, foram introduzidos novos programas urbanos, acompanhando os ajustes financeiros já citados - reforma fiscal, política tarifária e redefinição do padrão de financiamento - "em nome de cidades auto-sustentáveis". Tais ajustes seriam radicalizados nos anos 1990, com uma agenda para os campos econômico, social e político, retomando os projetos de "urbanização de baixos padrões" e "auto-ajuda", mas intensificando a difusão dos modelos de "gestão urbana empresarial" e de "competição entre cidades", bem como do conceito de "governança", num contexto de reforma do Estado.

O financiamento ao programa de recuperação do centro de São Paulo, portanto, se enquadra na última fase de ajustes dos organismos multilaterais, a qual desperta interesse especial para essa pesquisa. Uma fase em que os projetos de "revitalização urbana" de áreas centrais, além do turismo e da preservação do patrimônio histórico, passaram a enfocar a promoção de parcerias público-privadas, com vistas a obter ganhos imobiliários (MEZA MOSQUERA, 2007, p.110).

Os programas que passaram a ser financiados nos anos 1990 exacerbaram a "lógica financeira" das ações públicas iniciada nas décadas anteriores, exigindo a redução de gastos sociais, a profissionalização da máquina pública e a auto-suficiência financeira das cidades. Com o rompimento do padrão de repasse de recursos dos governos centrais para as localidades e a descentralização dos sistemas nacionais de políticas de Bem-Estar, os bancos multilaterais operavam (ainda operam) na racionalidade da "recuperação plena de custos" e da competição entre as cidades por consumidores e contribuintes. Defendiam a ampliação das taxas de impostos urbanos, a cobrança do preço real pelos serviços públicos, a retirada dos subsídios de produtos "não exportáveis" (alimentação, habitação, água, energia, transporte), e a canalização de investimentos em produtos "exportáveis" (ARANTES, 2004, p.54).

Enquanto as políticas sociais deveriam ser pensadas de acordo com a capacidade de pagamento dos beneficiários - reduzindo os padrões dos bens e serviços socialmente necessários, numa visão "economicista" da pobreza - as novas políticas para as cidades eram orientadas a aumentar 
a "produtividade urbana" e sua competitividade dentro da macroeconomia - conforme as teorias da "cidade-global"112. Os bancos processaram um "ajuste estrutural das cidades" com base na eficácia econômica dada pela intervenção por projetos, contribuindo - desde os anos 1980 - com a transição do modelo moderno de planejamento urbano para o urbanismo do projeto estratégico. Seus financiamentos passaram a enfocar a aferição econométrica da lucratividade das ações públicas, a desregulação urbanística e as intervenções pontuais de renovação urbana em áreas "elegíveis", onde há garantias de retorno econômico dos investimentos realizados e de lucratividade para as empresas públicas e privadas que operam os projetos.

Dessa forma, através de seus pacotes de ajustes fiscais, gerenciais e urbanos, condicionados a liberação dos empréstimos, o BID e o Banco Mundial se tornam os principais difusores do ideário do planejamento estratégico e das técnicas do "marketing urbano" - se constituíram em "atores da imposição ideológica da 'globalização econômica" (FERREIRA, 2007, p.117) - em especial para cidades de países periféricos do capitalismo. Imposição essa que ganhou força num contexto em que os gestores públicos locais "dependem cada vez mais de financiamento desses organismos para realizar os investimentos necessários ao desenvolvimento de suas cidades" (FERNANDES, 2001, p.40). Como já apontado, Carlos Vainer (2000, p.75) destaca que “o modelo vem sendo difundido no Brasil e na América Latina pela ação combinada de diferentes agências multilaterais (BIRD, Habitat) e de consultores internacionais, sobretudo catalães, cujo agressivo marketing aciona de maneira sistemática o sucesso de Barcelona”. Apesar de não ter sido a experiência pioneira, Barcelona se tornou um exemplo paradigmático ("bem sucedido") do planejamento estratégico, como mostram diversos autores nacionais (entre eles: ARANTES, VAINER, MARICATO, 2000; MARICATO, 2001; FERREIRA, 2007).

\subsection{2. “BEST PRACTICES": UM MODELO PARA O AÇÃO CENTRO}

A divulgação de experiências "bem sucedidas" que seguiram a cartilha dos ajustes fiscais, gerenciais e políticos, tem sido primordial na atuação dos organismos multilaterais. Especificamente no campo das práticas urbanísticas, têm sido difundidas experiências consideradas "exitosas" que tiveram como objetivo a retomada econômica de áreas consideradas degradadas. Seguindo o ideário da "cidade-global" e o receituário do planejamento estratégico,

\footnotetext{
112 Vale destacar que Saskia Sassen, como uma das principais teóricas da "cidade-global" esteve presente em alguns seminários e workshops promovidos pelos organismos multilaterais, como o que ocorreu em Barcelona em 1997, organizado pelo BID, que discutiu as "boas práticas" urbanas na América Latina. Ver SASSEN, Saskia. "Las ciudades en la economía global” In ROJAS, E. \& DAUGHTERS, R. (org.). La ciudad en el siglo XXI. Simposio de buenas prácticas en gestión urbana en América Latina y el Caribe. Washington D.C.: BID, 1998, p.21-30.
} 
que abordamos na seção anterior, essas práticas buscaram adequar as cidades às necessidades da atual lógica de acumulação de capital - adaptando a "ideologia da globalização econômica" ao âmbito urbano (FERREIRA, 2007). São as "boas práticas" ("best practices") difundidas e recomendadas pelos bancos, através de incisiva publicidade, alinhada às estratégias de "marketing urbano", que visam "vender" receitas de intervenção e recuperação urbana, em que os conflitos inerentes a esse tipo de intervenção não aparecem (MEZA MOSQUEIRA, 2007; ARANTES, 2004).

A partir dos anos 1990, o BID passou a financiar projetos de "revitalização urbana", de recuperação de áreas históricas centrais, como o pioneiro programa para o centro de Quito (Equador), "considerando o grande potencial de desenvolvimento econômico" que proporcionam (MEZA MOSQUEIRA, 2007, p.109). Como apontado nos documentos oficiais do Ação Centro, "ainda que o banco não tenha financiado previamente programas integrados de reabilitação urbana", outras experiências já realizadas "foram levadas em conta para o desenho" do programa paulistano (BID, 2004a, p.9, item 1.35).

$\mathrm{Na}$ experiência de Quito, como é comum em projetos de "revitalização", partiu-se dos diagnósticos de "degradação" e "decadência" do centro, situação entendida como decorrente da saída de moradores de alta renda, atividades econômicas e investimentos privados, ainda que tenha se mantido a vivacidade urbana pelo aumento da freqüência de camadas populares. Esse processo acarretou sua ocupação por população de menor pode aquisitivo, por comércio informal de rua, o encortiçamento das antigas edificações e a não conservação dos edifícios de valor histórico (PEÑA, 1998). Desde o final da década de 1980, já considerada Patrimônio Cultural da Humanidade pela UNESCO (1979), a municipalidade vinha empreendendo esforços para a recuperação da área central, até que em setembro de 1994 foi aprovado junto ao BID o "Programa de Reabilitação do Centro Histórico de Quito", contando com 51,3 milhões de dólares, sendo 10,1 milhões da contrapartida local.

Em janeiro de 1996, foi montada a Empresa de Desenvolvimento do Centro Histórico de Quito $(\mathrm{ECH})$, uma entidade de economia mista e regime privado, que tinha o objetivo de coordenar e executar o projeto de recuperação do centro, através da promoção de investimentos privados e do fortalecimento gerencial e técnico do organismo executor do programa (BID, 2004b) ${ }^{113}$. A partir do paper elaborado pelo gerente da ECH, Teodoro Peña (1998), para o Simpósio de "boas práticas" que ocorreu em Barcelona em 1997, fica claro o receituário do BID (do planejamento 
estratégico) neste projeto: melhoria do ambiente urbano e consolidação de um "clima de estabilidade e confiança para fomentar investimentos privados orientados ao desenvolvimento local" e ao "crescimento econômico sustentável"; disponibilizar informações atualizadas da atividade econômica do centro a "empresários dinâmicos" interessados em investir, "facilitando o êxito" de novos empreendimentos; contratação de consultorias para assessorar a ECH na “avaliação financeira de projetos"; e "gerar uma cultura empresarial eficiente" através do apoio da $\mathrm{ECH}$ às entidades municipais envolvidas no programa, desburocratizando e descentralizando suas ações.

Respaldadas no pacote de ajustes fiscais e gerenciamento urbano operado pelo banco, as técnicas e estratégias de intervenção utilizadas neste programa serviram de exemplo "exitoso" para outros projetos na América Latina, embasando seus princípios. Como o próprio texto de Peña (1998, p.91) destaca, "[o programa] deseja constituir, como projeto pioneiro na América Latina, um modelo demonstrativo da forma que se pode conciliar a conservação do patrimônio, a habitabilidade e a dinâmica econômica".

Kara-José (2007) aponta que a experiência de Quito foi uma referência para a montagem do programa brasileiro Monumenta-BID, de recuperação do patrimônio cultural de cidades selecionadas, trazendo estratégias de intervenção urbana de caráter neoliberal. O BID também indicou essa "boa prática" como um exemplo para o Programa de Reabilitação do Cento de São Paulo - Ação Centro, em especial para o desenho de sua Agência de Desenvolvimento. Como apontado no capítulo 1, a Agência foi proposta como uma instância de gestão vinculada à Diretoria de Desenvolvimento da EMURB, com o intuito de promover articulações com a iniciativa privada e captação de recursos a serem investidos na área de atuação do programa, visando seu "desenvolvimento econômico e social sustentável" (DM 44.089/03, art. 11). Como destaca documento assinado por técnicos do BID, "Propuesta de Préstamo"

\footnotetext{
As experiências exitosas na articulação público-privada dos projetos do Centro Histórico de Quito (EC-0169) e de Recuperação Urbana de Montevidéu (UR-112) foram utilizadas para o desenho de um mecanismo de articulação com o setor privado para a instalação de negócios no centro. (BID, 2003, p.9) $)^{115}$
}

Como já destacado, outra referência para a Agência do Ação Centro foi a experiência da Agência de Desenvolvimento do ABC paulista, instalada no município de Santo André, contando com recursos do BID e coordenação da mesma gestora/urbanista que, posteriormente, ao assumir a presidência da EMURB em São Paulo (2002), passou a coordenar o Programa Ação Centro. Vale

\footnotetext{
114 Os documentos Propuesta de Préstamo são elaborados na etapa de aprovação dos projetos pelo BID, sendo apresentados para o Diretório Executivo do banco.

115 Posteriormente, no documento Informe de Proyecto, de outubro de 2004, a experiência de Montevidéu deixa de ser citada.
} 
destacar que a "constituição de uma gerência de gestão do programa" - a Agência - foi exigência contratual do financiamento com o BID, condicionada à liberação do primeiro desembolso de recursos (cláusula 3.02, b).

Apesar de ter sido iniciado um grupo temático, envolvendo representantes das secretarias municipais e da sociedade civil - em especial entidades como SECOVI (Sindicato das Empresas de Compra, Venda, Locação e Administração de Imóveis Residenciais e Comerciais de São Paulo) e Viva o Centro - para discutir o funcionamento da Agência, ela não foi implementada. Segundo a técnica responsável pelas instâncias de gestão e participação do programa ${ }^{116}$, os trabalhos do grupo avançaram a ponto de montar uma minuta de seu regimento interno, mas enfrentaram polêmicas com relação a alguns temas, como a origem dos recursos a serem utilizados, e acabaram sendo interrompidos com a mudança do governo municipal no final de 2004, sem definir seu formato final.

Além dos projetos financiados pelo BID, como o de Quito, o banco também indicou como referências para o Ação Centro as experiências de Londres, Nova Iorque, Barcelona e Paris, consideradas "exitosas". Elas foram apresentadas num seminário organizado pelo banco em agosto de 2002, que contou com "experts" internacionais e teve o intuito de "revisar os planos da municipalidade para a área central da cidade", "incorporando" e verificando sua "congruência" com as "melhores práticas internacionais" (BID, 2004a, p.9). O documento de 2003 (Propuesta de Préstamo), ainda destaca que, "principalmente, entre suas recomendações, o seminário indicou que a exemplo de Barcelona e Buenos Aires, São Paulo deveria utilizar uma agência de caráter público para implantar o programa de recuperação urbana" (BID, 2003, p.9).

Arantes (2004) destaca que um dos meios mais eficazes utilizados pelos bancos multilaterais para difundir as "boas práticas" urbanísticas tem sido os seminários e workshops internacionais, como o que ocorreu em Barcelona em 1997, e nos quais participam muitos dos consultores vinculados aos bancos e gestores de projetos "bem sucedidos". Como em todos os projetos financiados pelo BID, foram muitos os consultores internacionais envolvidos na montagem do Programa Ação Centro, entre eles Alfredo Garay, ex-vice-presidente da Corporación Antiguo Puerto Madero S.A. e ex-Secretário de Planejamento do Município de Buenos Aires (1989-1992), que coordenou os projetos de "revitalização" de Puerto Madero.

Conforme destaca o documento "Informe de Proyecto" (BID, 2004a), o estudo de Garay, intitulado "Creación de una Agencia de Desarrollo del Centro" (2003), indicou a estratégia de "orientar a

116 Renata Milanesi, em entrevista cedida à autora em janeiro de 2008. 
municipalidade para as formas mais efetivas de tirar partido das oportunidades de desenvolvimento concertado com o setor privado, que vão surgir uma vez iniciado o programa”, ou seja, quando lançado o processo de reabilitação (BID, 2004a, p.7). Esse teria sido o pressuposto básico que norteou a criação da Agência de Desenvolvimento do Centro. Um dos gestores do programa destacou também que "a constituição da Agência de Desenvolvimento do Centro (...) vem responder a uma estratégia, cada vez mais corrente, das administrações municipais assumirem políticas de fomento às atividades econômicas num contexto de crise, de aumento do desemprego e da competitividade entre cidades” (SILVA, 2004, p.30).

A partir da propalada ineficiência administrativa e perda de capacidade do Estado em investir na produção do espaço urbano, a idéia de co-gestão da coisa pública - ou "governança” - está na base da criação da Agência do Centro de São Paulo, de acordo com os modelos amplamente difundidos pelos defensores do planejamento estratégico e pelos bancos multilaterais. Ao mesmo tempo, as restrições ao endividamento dos poderes públicos municipais, impostas com a regulamentação da Lei de Responsabilidade Fiscal em maio de 2000 - a despeito do financiamento do BID em questão - acarretaram uma drástica redução de recursos e uma busca por novas soluções, justificando ações em parceria com a iniciativa privada (PMSP/SEHAB, 2004a), como no caso da Agência.

Além do tema das agências de desenvolvimento - "novos arranjos institucionais", de caráter financeiro e "legalmente independente" (ARANTES, 2004, p.59-60) - outros elementos do modelo da gestão urbana empresarial não ficaram de fora do Ação Centro. Entre eles, a contratação de uma empresa privada gerenciadora, com técnicos experts que se responsabilizam por todo o trâmite operacional-burocrático do projeto, inclusive da comprovação de gastos, desembolsos e contrapartidas - uma terceirização da gestão pública. Sendo uma exigência padrão nos contratos de financiamento, empresas funcionam como "um mecanismo de privatização estimulado pelos bancos multilaterais", entendendo a gestão pública como inapta para gerir um programa internacional (ARANTES, 2004).

O texto "Informe de Proyecto" justifica que "a contratação de uma empresa gerenciadora liberar-lheá [a EMURB] tempo e pessoal para as funções de articulação com o setor privado e de seguimento e avaliação do programa" (BID, 2004a, p.27, item 4.8). Entretanto, essa exigência do banco foi constantemente questionada pelos gestores públicos, retardando a contratação da gerenciadora até a mudança de governo. Segundo a Superintendente de Acompanhamento de 
Projetos Urbanos da EMURB à época ${ }^{117}$, havia um receio com relação ao acúmulo de conhecimento sobre o programa ficar com a gerenciadora e não com a Prefeitura, o que envolvia ter informações, documentos, histórico da implementação e o conhecimento especializado da gestão dos projetos. Até o final de 2004, a equipe gestora conseguiu montar um sistema operacional dentro da própria EMURB, com um conjunto complexo de procedimentos que envolvia interlocutores - "espelhos" - em cada órgão subexecutor. Para cada subexecutor também havia um gestor dentro da EMURB responsável pelo apoio técnico à montagem e formatação de seu conjunto de projetos. Hoje, porém, o gerenciamento do programa está com o consórcio Planserve/Núcleo/Engea (PÓLIS/CARE, 2007), cuja equipe se instalou dentro do espaço físico da EMURB, conjuntamente com os gestores públicos.

Tanto a Agência de Desenvolvimento quanto a empresa gerenciadora integram um mesmo modelo de gestão da ação pública difundido pelo Banco Mundial e pelo BID: a chamada "governança" (ou "bom governo"). Tal modelo de gestão é condizente e essencial aos ajustes fiscais e urbanos impostos pelos bancos que, em última instância, através de suas regras e novas instituições, livres daquilo que consideram ser a ineficácia dos governos locais (o que realmente há), praticam uma ingerência sobre os poderes locais tomadores de empréstimos (OSMONT, 1998, apud Arantes 2004, p.82-3) ${ }^{118}$.

Justificando-se na ineficiência e inaptidão da gestão pública, e seguindo os preceitos do planejamento estratégico, o Banco Mundial passou a defender mudanças no "tamanho, estrutura e papel do setor público" (PRICE, 1991, p.1, apud ARANTES, 2004, p.83) ${ }^{119}$, introduzindo o modelo da "governança", mais flexível, ágil, "tecnicisado" e propício às parcerias com a iniciativa privada e, portanto, às demandas de investidores e empreendedores. O BID também utiliza o termo, mas enfocando na "modernização da administração pública" (op.cit, loc.cit.).

No caso do Ação Cento, a própria "viabilidade" do programa estava condicionada, entre outros fatores, à gestão eficiente e flexível, ou seja, à "viabilidade das instituições" e à existência de "instrumentos administrativos para que as instituições possam cumprir a totalidade das ações que conduzem ao alcance dos objetivos da operação”. Sendo a EMURB o órgão executor, o governo deveria fazer-lhe "os ajustes pertinentes e fortalecer-lhe institucionalmente para exercer as novas atividades exigidas pelo programa, principalmente na coordenação com os demais subexecutores

\footnotetext{
117 Ursula Dias Peres. Em entrevista cedida à autora em dezembro de 2007. Peres foi Superintendente entre 2003 e 2004.

118 OSMONT, Annik. "La Gouvernance: un concept mou une politique ferme". In Les Annales de la recherche urbaine, n. 80-81. Paris, 1998.

119 PRICE, Lisette. Governance: experience in Latin America and the Caribbean. working paper. Washington: World Bank, 1991.
} 
e na articulação com o setor privado, para atrair investimentos” (BID, 2004a, p.27, item 4.4). Como apontava o documento "Propuesta de Préstamo":

(...) mais que criar uma nova agência para o centro, foi recomendada a utilização da EMURB, que contava com experiência nos tipos de intervenções a ser financiadas e com capacidade legal para, em associação com o setor privado, realizar empreendimentos imobiliários específicos, assim como a mescla de componentes que deveriam ser contemplados em um programa de renovação urbana. (BID, 2003, p.9)

Vale lembrar que a "governança" está associado à idéia de participação social e ao "entendimento de 'união dos agentes sociais na gestão"' (CALAME \& TALMANT. 2001, p.21, apud FERREIRA, 2001, p.3) ${ }^{120}$, representando uma pretensa “inovação democrática". No entanto, como já apontamos anteriormente, esse novo léxico dos organismos multilaterais tem servido mais para a criação de consensos em torno da crise econômica - apontada anteriormente - e da legitimidade dos projetos de revitalização urbana - escondendo os conflitos - do que à abertura da gestão dos projetos à participação - por natureza conflituosa. Ocorre, sim, uma captura das reivindicações e "bandeiras" originalmente da esquerda democrática - como a autogestão dos recursos e políticas públicas, a descentralização e importância ao poder local - trazendo-as para um discurso de cunho neoliberal que defende a terceirização e privatização da gestão pública. Como aponta Maricato (2001, p.57), "apesar da roupagem democrática e participativa, as propostas dos 'planos estratégicos', vendidos às municipalidades latino-americanas, combinaram perfeitamente ao ideário neoliberal que orientou o 'ajuste' das políticas econômicas nacionais por meio do Consenso de Washington (que, aliás, também vestiu uma roupagem democrática)”.

O escamoteamento dos conflitos e dissensos que se dá a partir dessa captura de "bandeiras", por sinal, contribuiria diretamente para a "melhoria do clima dos negócios", necessária aos projetos estratégicos de retomada do crescimento econômico, fortalecendo as "vantagens comparativas" de cada cidade, ainda de acordo com a lógica dos bancos e alinhando-se às teorias da "cidadeglobal". Segundo o presidente do BID,

(...) esse novo consenso político começa a surgir do esgotamento, pelas mais diversas razões, de diversos governos baseados em uma cultura política populista ou ideológica, confrontacional e conflitiva, pouco disciplinada ou maximalista. Em seu lugar, gesta-se uma nova cultura cívica, mais desiludida e mais pragmática, menos impaciente e mais madura, menos inclinada ao conflito e mais disposta à busca de convergências, mais afastadas de extremos e mais orientada pelo centro - uma desistência da impaciência política, com revalorização da moderação, da estabilidade e dos consensos. (ENRIQUE IGLESIAS, 1992, p.57, apud ARANTES 2004, p.87) ${ }^{121}$

${ }^{120}$ CALAME, Pierre \& TALMANT, André. A Questão do Estado no coração do futuro. Petrópolis: Vozes, 2001.

121 IGLESIAS, Enrique. Reflexiones sobre el desarrollo económico. Washington: BID, 1992. 
Nota-se em alguns textos de autoria de gestores do Programa Ação Centro, a preocupação em relação à recuperação e valorização simbólica do centro da cidade, como espaço de expressão do "orgulho do cidadão paulistano pela sua memória e história" (SOMEKH, 2004b, p.7). A importância dada a essa valorização, por sua vez, pareceu conduzir a construção de um consenso em torno da necessidade de intervenção na área central, a fim de "resgatar a auto-estima da população" através de um "processe coletivo de investimento afetivo" (op.cit., loc.cit.). Outro gestor ainda ressalta que “uma coalizão de interesses em relação aos desígnios da área central já se vinha delineando desde os anos 1990. (...) A ênfase da administração Marta Suplicy em relação ao Centro deu um novo e fundamental impulso na consolidação dessa convergência” (SILVA, 2004, p.29).

Garantir um ambiente seguro e favorável aos negócios é essencial ao alcance dos objetivos de um programa de revitalização urbana que segue os moldes dos bancos multilaterais e, portanto, os preceitos do planejamento estratégico e do "city marketing". Como visto na seção anterior, o pressuposto central desse receituário é que a recuperação de áreas urbanas consideradas obsoletas e degradadas deve ocorrer mediante atração de investimentos privados - o cerne das teorias da "cidade-global": dotar as cidades de atributos que as tornem aptas a competir pela atração de capitais.

Eduardo Rojas (1998), especialista em desenvolvimento urbano do BID, explica que o "problema" contemporâneo das áreas centrais se dá num "círculo vicioso", em que a falta de interesse do mercado imobiliário, que mantém o preço da terra baixo e, portanto, diminui a arrecadação pública, é reiterada pela falta de manutenção e melhorias nas infra-estruturas e nos espaços públicos; exatamente pela insuficiência de recursos públicos. Essa falta de manutenção afugenta os investidores imobiliários e instituições financeiras - que se deslocam para localizações com melhores condições ambientais, maior flexibilidade no uso do solo e certeza quanto à futura valorização de seus investimentos - deprimindo ainda mais o valor da terra nas áreas centrais.

Com base nessa explicação, o especialista defende que o setor público lidere os projetos de revitalização dessas áreas, através de ações concertadas com a iniciativa privada, revertendo e quebrando o "círculo vicioso" da deterioração. Uma receita que exige considerável aporte de recursos públicos na melhoria da infra-estrutura e dos espaços públicos, com o propósito de "gerar as necessárias externalidades positivas para estimular o interesse dos investidores" (ROJAS, 1998, p.77); receita essa que consta no "Informe de Proyecto" do Ação Centro, em seu item 4.2 (BID, 2004a, p.27). Reverter a "degradação" significa, portanto, promover uma valorização imobiliária por meio do aporte de recursos públicos na criação de um "ambiente favorável aos 
negócios", atraindo capital privado e aumentado a arrecadação pública - uma retomada econômica. Uma completa inversão do sentido de público e do papel do Estado como garantidor de interesses coletivos e, portanto, contrário ao modelo de Estado forte presente nas experiências de "intervenção na cidade existente" que abordamos anteriormente.

Relembrando que, segundo o receituário do planejamento estratégico, como afirmam Castells \& Borja (1996, p.160), “o governo local deve promover a cidade para o exterior, desenvolvendo uma imagem forte e positiva apoiada numa oferta de infra-estruturas e de serviços (...) que exerçam a atração de investidores, visitantes e usuários solventes à cidade...”. Para tal, as técnicas da gestão urbana empresarial devem ser intensamente praticadas, como difundem os bancos multilaterais.

O Programa Ação Centro não escapou desses preceitos, como pudemos ver no primeiro capítulo dessa pesquisa. Seu "principal benefício" foi apresentado como sendo "o desenvolvimento econômico e social da área central de São Paulo, mediante a atração, dinamização e manutenção de atividades econômicas compatíveis com o centro reabilitado da cidade, traduzido num incremento do produto interno bruto da cidade de São Paulo e do tamanho do mercado efetivo de trabalho" (BID, 2004a, p.33). Pretendia "reverter o processo de degradação e desvalorização afetiva do centro" (PMSP/EMURB, 2004a) através de estratégias como: "recuperação de áreas degradadas", "melhoria da qualidade ambiental" e "fomento à pluralidade econômica". O "Informe de Proyecto" mostra a expectativa que se tinham com relação ao programa, em seu item de justificativa: ele "executará investimentos e ações públicas que resolvem os problemas detectados e induzem investimentos privados de recuperação e desenvolvimento do centro" (BID, 2004a, p.27, item 4.2).

Entre seus componente e ações, percebemos a intenção de atrair a instalação de novos usos e atividades, moradores de renda média, órgãos do poder público e a canalização de novos investimentos privados. Como apresentamos no capítulo 1, vários componentes e ações do programa serviriam para criar o "ambiente seguro e favorável" aos negócios: Projetos Motores (Pq. Dom Pedro II); reforma de praças (Sé, República, Roosevelt, Patriarca, etc.); melhoria de calçadas (Corredor Cultural, Quadrilátero Piloto); recuperação de edifícios de valor histórico; micro acessibilidade (abertura de calçadões); controle de enchentes (piscinões); retirada de 30\% das linhas de ônibus e instalação de garagens subterrâneas; inibição das atividades informais; e, no limite, atendimento aos moradores de rua (tirando-os da rua). Durante a montagem do programa, o BID defendeu a estratégia de realizar projetos que "alavancariam" os investimentos privados no centro. 
Uma parte dos técnicos do BID achava que era melhor concentrar as intervenções mais pesadas em infra-estrutura urbana, porque se você resolve a infra-estrutura urbana, atrai investimentos privados, capital etc., e isso potencializa a atração de novos investimentos, que trazem outros investimentos, e assim por diante, gerando uma reação em cadeia (PERES, 2007) ${ }^{122}$.

Em conjunto com os mecanismos de incentivo fiscal-tributário e a flexibilização da legislação urbanística vigente (Lei de Incentivos Seletivos, manutenção da Lei de Fachadas e da Operação Urbana Centro, criação da Operação Urbana Diagonal Sul, Planos Regionais da Sé e da Mooca), essas ações e projetos funcionariam como indutores aos investimentos imobiliários e a instalação de novas atividades. Para o "desenvolvimento econômico e social local", seria necessário implementar "incentivos para a renovação do tecido produtivo, criando um pólo de atração de micro e pequenas empresas", em geral mais rentáveis do que as existentes, como "empresas do setor terciário de alta tecnologia" (SOMEKH, 2004b, p.4) e mesmo "edifícios inteligentes" (op.cit., p.2).

Vale apontar novamente que a elaboração dos Planos Regionais das subprefeituras Sé e Mooca deveria promover "o marco regulador estável de que requerem os investidores imobiliários para retomar seus investimentos destinados ao uso residencial e não residencial para o setor terciário, com instalações de última geração, assim como para estimular a demanda por imóveis no centro" (BID 2004a, p.11, item 2.3). Tanto na "Propuesta de Préstamo" (2003), como no "Informe de Proyecto" (2004), a possibilidade (remota) de não aprovação da lei dos planos regionais foi apontada como um risco para o "êxito" do programa (BID, 2004a, p.34, item 4.32). No entanto, como sabemos, sua regulamentação ocorreu em agosto de 2004.

Não negamos a possível importância de ações como essas para a recuperação do centro, para a melhoria de seus espaços públicos, sua infra-estrutura e a qualidade de vida em geral, mas nos parece que no contexto de um financiamento externo, em que forçosamente devem ser seguidos os “ajustes" impostos pela instituição multilateral de crédito, elas servem mais para reforçar preceitos de cunho neoliberal. Alinharam-se àquilo que tem se constituído como idéia dominante da intervenção de áreas centrais: o planejamento estratégico - promover investimento privados, concedendo-lhes benefícios, por meio de aportes públicos na melhoria do ambiente urbano, basicamente infra-estrutura e espaços públicos, o que Arantes, Vainer e Maricato (2000) chamaram de "pensamento único".

A atração de investimentos privados, tão destacada nos documentos oficiais do programa Ação Centro, está associada à idéia de "produtividade da cidade" e "sustentabilidade econômica" do

\footnotetext{
122 Peres, 2007. Em entrevista cedida à autora em dezembro de 2007. Luis Octavio da Silva, outro gestor público envolvido no
} programa, também destacou esse enfoque do banco financiador em entrevista cedida a autora em janeiro de 2008. 
projeto realizado. Segundo Arantes (2004, p.71-72), “o Banco Mundial e o BID definem como financiáveis apenas projetos que comprovadamente tenham condições de obter taxas de retorno e que garantam ou mantenham a lucratividade das empresas públicas e privadas" envolvidas nas intervenções. $\mathrm{O}$ autor ainda destaca que, diante dessa racionalidade de "recuperação dos custos do projeto", os bancos passaram a financiar intervenções apenas em áreas "elegíveis", onde os projetos possam atrair investimentos e consumidores e, assim, cobrir seus custos.

No caso de projetos de "revitalização urbana", isso significa atrair usos mais rentáveis, consumidores de maior poder aquisitivo, gerar valorização fundiária e imobiliária da área e aumentar a arrecadação pública. Como citado anteriormente, o propósito do Programa Ação Centro seria executar "investimentos e ações públicas que resolvam os problemas detectados e induzam investimentos privados de recuperação e desenvolvimento do centro", gerando um benefício traduzido (medido) no "incremento do produto interno bruto da cidade de São Paulo e do tamanho do mercado efetivo de trabalho". Para tal, seria adotada uma "estratégia de intervenção que maximiza os benefícios econômicos líquidos” (BID 2004a, p.27, item 4.2); estratégia essa embasada "nos resultados de uma avaliação econômica que considerou os impactos macro e micro das intervenções do programa" (op.cit., loc.cit.) e definida, portanto, a partir de uma ótica econômico-financeira.

Tal avaliação foi realizada pelo consultor francês indicado pelo BID Remy Prud’homme (2002), analisando os impactos econômicos em 4 diferentes cenários de investimentos: negócios, cultura, habitação e integrado, de onde foi selecionado o cenário integrado, que reúne investimentos nos três setores. Através de uma "análise macroeconômica" foi mostrado que, comparativamente aos outros cenários, o integrado possibilitaria um maior aumento do PIB e do valor, gerando uma maior Taxa Interna de Retorno Econômico (TIRE) em relação aos custos do programa (BID 2004a, p.29, item 4.10), conforme tabela 4.

Posteriormente, a avaliação econômica do programa foi refeita num estudo contratado pela EMURB - "Impactos econômicos e sociais do Programa de Renovação do Centro" (PMSP/EMURB/LUME, 2003) - coordenado pelo economista Ciro Biderman, em que se propôs um modelo econométrico para aferir o retorno financeiro de suas ações. Segundo o "Informe de Proyecto", "a avaliação macroeconômica espacial consiste em estimar o benefício econômico agregado (incremento do PIB do centro de São Paulo), resultado da análise da produtividade e acessibilidade espacial da RMSP e do centro do município” (BID, 2004a, p.28, 
item 4.9) ${ }^{123}$. Tais análises econômico-financeira e econométrica, em conjunto com uma análise da capacidade institucional do executor do projeto, integram o processo de preparação do escopo do financiamento, padrão nos contratos com o BID e que culminam na elaboração do Marco Lógico - o conjunto de indicadores a partir dos quais serão averiguados os impactos e efeitos da implementação do programa (PÓLIS/CARE, 2007, p.35-36).

\section{TABELA 4: CENÁRIOS DE INVESTIMENTOS}

\begin{tabular}{|c|c|c|c|c|c|c|c|c|c|}
\hline \multirow{3}{*}{$\begin{array}{c}\text { Variáveis } \\
\text { Características Demográficas: }\end{array}$} & \multicolumn{9}{|c|}{ Cenários São Paulo 2010} \\
\hline & \multirow[t]{2}{*}{ Valor base } & \multicolumn{2}{|c|}{ habitação } & \multicolumn{2}{|c|}{ Cultural } & \multicolumn{2}{|c|}{ Negócios } & \multicolumn{2}{|c|}{ Integrado } \\
\hline & & $\Delta \%$ & $\mathbf{N}^{\mathbf{o}}$ & $\Delta \%$ & $\mathbf{N}^{\mathbf{0}}$ & $\Delta \%$ & $\mathbf{N}^{\mathbf{o}}$ & $\Delta \%$ & $\mathbf{N}^{\mathbf{0}}$ \\
\hline Domicílios (mil) & 42.3 & $66 \%$ & 70.1 & $-12 \%$ & 37.3 & $-2 \%$ & 41.6 & $12 \%$ & 47.2 \\
\hline Taxa de Ocupação & 2,54 & $1 \%$ & 2,56 & $0 \%$ & 2,54 & $0 \%$ & 2,53 & $0 \%$ & 2,54 \\
\hline População & 107.5 & $67 \%$ & 179.4 & $-12 \%$ & 94.7 & $-2 \%$ & 105.4 & $12 \%$ & 120.0 \\
\hline Trabalhadores (mil) & 48.3 & $66 \%$ & 80.3 & $-12 \%$ & 42.5 & $-2 \%$ & 47.3 & $12 \%$ & 53.9 \\
\hline Renda (R\$/mês) & 1.509 & $33 \%$ & 1.009 & $11 \%$ & 1.681 & $24 \%$ & 1.870 & $-2 \%$ & 1.479 \\
\hline Taxa de Vacância & $32 \%$ & $30 \%$ & $22 \%$ & $-10 \%$ & $29 \%$ & $0 \%$ & $32 \%$ & $-20 \%$ & $26 \%$ \\
\hline Área residencial km2 & 3,5 & $26 \%$ & 4,4 & $-16 \%$ & 2,9 & $-2 \%$ & 3,4 & $2 \%$ & 3,6 \\
\hline Valor (US\$ milhões) & 466.0 & $26 \%$ & 588.3 & $-16 \%$ & 389.5 & $9 \%$ & 508 & $26 \%$ & 587.0 \\
\hline \multicolumn{10}{|l|}{ Mercados e Preços: } \\
\hline Emprego (mil) & 428.8 & $5 \%$ & 451.3 & $9 \%$ & 465.5 & $1 \%$ & 434.4 & $7 \%$ & 460.1 \\
\hline Salário (R\$/mês) & 1.584 & $-1 \%$ & 1.575 & $-2 \%$ & 1.554 & $1 \%$ & 1.592 & $-1 \%$ & 1.576 \\
\hline Área comercial (km2) & 9,2 & $0 \%$ & 9,2 & $10 \%$ & 10,1 & $20 \%$ & 11,0 & $30 \%$ & 12,0 \\
\hline Valor (US\$ milhões) & 1.390 & $0 \%$ & 1.390 & $10 \%$ & 1.529 & $28 \%$ & 1.785 & $49 \%$ & 2.070 \\
\hline$\Delta$ PIB (US\$ milhões/ano) & 78.000 & & 27,9 & & 30,8 & & 36,0 & & 42,1 \\
\hline TIRE (\%) & & & 4,0 & & 5,7 & & 8,3 & & 14,8 \\
\hline
\end{tabular}

Fonte: BID, 2004a, p.8.

A "natureza espacialmente focalizada" do programa - nos distritos Sé e República, sua Área de Interesse - permitiria tirar o "máximo proveito das sinergias resultantes das dinâmicas e dos investimentos a serem financiados” (BID, 2004a, p.27, nota 6 do item 4.2). Entende-se porque o BID exigiu que fosse descartada a opção de englobar os 10 distritos da antiga Administração Regional da Sé - como proposto pelo Reconstruir o Centro - uma vez que, de acordo com a lógica de recuperação dos custos, "ações vastamente pulverizadas corriam o risco de não se potencializarem umas às outras e o programa diluir-se por uma área por demais vasta" (SILVA, 2004, p.28). Ou seja, a Área de Interesse do programa seria a área "elegível” para os projetos, onde haveria potencial de atração de investimentos e consumidores que garantiriam seu retorno econômico.

Segundo os técnicos do BID, as ações que envolviam esse projeto estavam muito pulverizadas, portanto, uma das tarefas que tivemos foi convencer o banco a manter o

123 Não se pretende com essa pesquisa averiguar o mérito da metodologia de análise econômica utilizada no programa, mas apenas identificar e apontar a lógica econômica e financeira que norteou sua montagem. 
financiamento e concentrar as ações, otimizando-as como ações estratégicas. (SOMEKH, 2004a, p.79-80)

Outro argumento para a focalização dos investimentos do programa é que a área dos 10 distritos centrais seria um "território bastante extenso e que não coincide precisamente com aquele afetado pelas problemáticas características de áreas centrais” (SILVA, 2005). Segundo o autor, a isso se soma o fato de que o montante de recursos, apesar de siginificativo, é "reduzido face ao cabedal de demandas existente". No entanto, essa alteração da área foco - em relação ao Reconstruir o Centro - ao lado da prioridade dada a determinadas ações, explicitou o objetivo principal do programa em gerar uma redinamização econômica e a valorização imobiliaria, através do estímulo aos investimentos privados e, em decorrência, da transformação do perfil de uso e ocupação do solo no centro, especialmente na Área de Interesse. Tal estímulo - ou "efeito de sinergia" como apontado no capítulo 1 - seria possibilitado pelas melhorias do ambiente urbano, envolvendo as intervenções urbanísticas e outras ações a serem realizadas com os investimentos do programa, ou seja, com recursos públicos. Uma estratégia que inverte completamente o sentido de público e o papel do Estado na organização e controle do território e do ambiente ambiente construído, na medida em que subordina a política pública aos interesses e potencial de alavancagem do capital privado.

Desse modo, ao observar as áreas de abrangência de cada componente do Ação Centro, como abordado no capítulo 1, percebe-se os diferentes pressupostos que os condicionou. Ou seja, a maior parte das intervenções que buscavam a melhoria do ambiente urbano - construção do "ambiente favorável aos negócios" - recaiu sobre a Área de Interesse e imediações do Parque Dom Pedro II - a área "elegível” onde a "alvancagem” seria possível - enquanto os programas de habitação e de assistência social tiveram a maioria de suas ações implantada e prevista fora dessa área foco. A inserção do componente habitacional foi objeto de discordâncias entre a Prefeitura e o BID, como veremos adiante, o que talvez tenha contribuído para que a maioria de suas ações fosse localizada fora da Área de Interesse.

Percebe-se que, como já apontou Arantes (2004, p.69), "a lógica financeira passa a prevalecer como definidora da escolha de intervenções públicas e privadas rentáveis”, conduzindo à racionalidade da "recuperação de custos" dos projetos. Essa racionalidade, segundo o autor, teve origem nos ajustes operados pelos bancos multilaterais na década de 1980, com a defesa pela realização de projetos pontuais ou pilotos (ao invés de planos), por serem de mais fácil medição e aferição quanto ao retorno financeiro (op.cit., p.40). Em nome da eficácia econômica, a intervenção por projeto foi difundida pelos bancos, mesmo com a retomada da idéia de plano nos anos 1990 (não mais o moderno e sim o estratégico). Parece que, seguindo essa lógica do 
enfoque no projeto, o BID defendia a realização de piscinões, obras viárias, reformas de praças enfim, obras - para a recuperação da área central de São Paulo, em detrimento de ações e programas de atendimento social, trabalho e geração de renda, muito mais difíceis de medir e “operacionalizar", como apontado por 3 de nossos entrevistados ${ }^{124}$. As exigências e regras operacionais e de gerenciamento, inclusive, reforçam essa lógica financeira do projeto.

Além da "viabilidade institucional" e "macroeconômica", outras análises foram realizadas para aferir a "viabilidade" do programa: "técnico-econômica" de uma mostra de projetos; "financeira" e "ambiental e social" (BID, 2004a, p.27, item 4.3). Entre elas, a análise financeira é a que melhor explicita a racionalidade da "recuperação de custos" a que estamos nos referindo.

Nos documentos oficiais do Ação Centro foi apontado que há um risco de âmbito fiscal que poderia impedir o município de honrar seu "compromisso com os recursos da contrapartida do programa”, diante de uma conjuntura econômica nacional instável e de ajustes fiscais que levaram à redução de suas receitas em 800 milhões de dólares entre 2000 e 2003 (BID, 2004a, p.30, itens 4.15 e 4.18). Desse modo, ao lado das reformas orçamentária (corte de gastos, principalmente com pessoal) e fiscal (taxas de iluminação e resíduos sólidos, e previsão do IPTU progressivo), o aumento da arrecadação tributária que poderia ser propiciado pelos impactos econômicos do programa foi apresentado como primordial para sua "viabilidade financeira".

O programa tem impacto positivo nas receitas fiscais do município em função do incremento esperado no produto do município. Em efeito, o aumento previsto na arrecadação, por conta dos incrementos de IPTU e ISS, é de US\$13,4 milhões por ano, enquanto o incremento do custo de operação e manutenção [do programa] é de US\$ 6,5 milhões anuais. (BID, 2004a, p.31, item 4.19)

Os indicadores de monitoramento e avaliação do programa - Marco Lógico - também foram elaborados a partir dos estudos do impacto econômico das ações, de acordo com o cenário de investimento integrado que embasou a estratégia de intervenção adotada, refletindo a "racionalidade da recuperação de custos". Como vimos no capítulo 1, mesmo possuindo indicadores de "monitoramento da população vulnerável", a maior parte dos indicadores eram de caráter econômico-financeiro e, de modo geral, pretendiam medir: o aumento (10\%) da superfície aprovada para construção e reforma; a diminuição da taxa de desocupação dos imóveis residenciais; o aumento da especialização terciária da área central; a valorização imobiliária (valores de aluguéis); o aumento do consumo de energia elétrica; o aumento do mercado de trabalho; e aumento da arrecadação pública (ISS, ITBI, ICMS).

124 Ursula Dias Peres, em entrevista cedida à autora em dezembro de 2007; Renata Milanesi, em entrevista cedida à autora em janeiro de 2008; Luis Octávio da Silva, em entrevista cedida à autora em janeiro de 2008. 
Numa aparente contradição, foi dentro dessa lógica financeira que a prefeitura conseguiu inserir os componentes de assistência social, geração de trabalho e renda, e de Habitação de Interesse Social (HIS) no escopo do Ação Centro. Assim como a construção de um "ambiente favorável aos negócios", esses componentes integraram as estratégias do programa, visando "reverter o processo de degradação e desvalorização afetiva do centro", mas sob a rubrica da "inclusão social". No entanto, como já apontado, independentemente do mérito dos programas de assistência e trabalho, cujo "público alvo" era composto por moradores de rua, catadores e ambulantes, os resultados esperados de tais ações - reordenamento e inibição do comércio ambulante, atendimento na rede de proteção social, retirando os moradores de rua das ruas contribuiriam diretamente com a construção do "ambiente favorável aos negócios".

Como destacaram os gestores públicos entrevistados ${ }^{125}$ para esta pesquisa, o BID foi contrário à destinação de recursos para produção de HIS, na medida em que seus beneficiários não teriam condições de pagar pelos custos dos projetos, ou seja, não haveria retorno ${ }^{126}$. Esse foi, por sinal, o principal embate entre banco e prefeitura ao longo da montagem do programa, que refletia a preocupação dos gestores locais em garantir a "inclusão social" ao longo do processo de reabilitação. O enfoque na "inclusão social" foi explicitado nos documentos oficiais que analisamos e apontado pelos gestores entrevistados como o "caráter inovador" do programa, a "marca maior" da gestão da Prefeita Marta Suplicy. Tal enfoque, diante de tamanha imposição de padrões do banco financiador, como vimos até aqui, dotou o Programa Ação Centro de um caráter ambíguo, construindo um discurso que deveria servir tanto aos princípios impostos pelo banco - em grande parte compartilhados pelo governo local - como ao objetivo de realizar uma reabilitação com "inclusão social”.

O componente habitacional, em especial a modalidade de Locação Social, como apontado anteriormente, exigia considerável montante de subsídios, o que seria inconcebível na visão do BID. Como aponta Arantes (2004, p.150), a partir de entrevistas com a coordenadora geral e a gestora responsável pelos programas habitacionais - Nádia Somekh e Helena Menna Barreto, respectivamente - “o foco da prefeitura estaria 'na inclusão social' enquanto para o banco 'o sucesso do programa é a valorização imobiliária". Ao contrário de habitação social, da

\footnotetext{
125 Ursula Dias Peres, em entrevista cedida à autora em dezembro de 2007; Renata Milanesi, em entrevista cedida à autora em janeiro de 2008; Luis Octávio da Silva, em entrevista cedida à autora em janeiro de 2008; Nádia Somekh, em entrevista cedida à autora em janeiro de 2008.

126 Arantes (2004) analisou alguns dos financiamentos dos bancos multilaterais voltados a projetos de "combate à pobreza" e mostrou que o modelo defendido (ou imposto) é aquele que define os níveis e qualidade dos serviços socialmente necessários de acordo com a capacidade dos beneficiários em pagar pelos investimentos ("ability to pay"), visando à recuperação dos custos dos projetos. Modelo esse que foi válido para os programas habitacionais, como o PAC-BID - Programa de Atuação em Cortiços da Companhia de Habitação do Governo do Estado, também financiado pelo BID.
} 
constituição de um estoque público de moradia para famílias de baixa renda (abaixo de 3 salários mínimos), o BID defendia habitação para classe média, propondo "pagar 10 mil reais de subsídio direto ao que eles chamavam de 'os pioneiros"” (Helena Menna Barreto, apud Arantes, op cit). Somekh ${ }^{127}$ também apontou as discordâncias entre o BID e os gestores locais quanto à habitação social:

(...) o BID não queria que tivesse [habitação] para a baixa renda, queria para a renda média. Esta foi uma batalha que a Helena [Menna Barreto] defendeu muito bem e que nós conseguimos superar. Tivemos também um seminário só sobre a questão habitacional, e eles [os técnicos do BID] se convenceram que tinha que incluir no programa, tanto que financiaram a Favela do Gato. Isso foi uma vitória nossa, mas eles não queriam.

O ainda, como aponta Luis Octávio da Silva, um dos gestores do programa:

Ao longo das diversas missões de acompanhamento da formatação do programa, a delegação do banco deixava clara a sua predileção pelas ações de melhoria do sistema de transporte e de infra-estrutura de forma geral. No desenho final do programa, entretanto, prevaleceram os objetivos da prefeitura. (SILVA, 2004, p.33).

Ao final, o banco cedeu às argumentações dos técnicos da prefeitura, e o componente habitacional foi inserido no escopo do financiamento, ainda que com restrições (locação social como projeto piloto e com limite de 1.600 unidades a serem produzidas). Segundo a gestora responsável por tal componente, Helena Menna Barreto, o constante diálogo com os técnicos do banco forçou os gestores locais a argumentar e brigar por aquilo que a prefeitura queria (apud ARANTES, 2004, p.151).

Como apontam os documento do Ação Centro e de seu componente habitacional, a inserção dos programas de HIS no contexto da reabilitação da área central exigia a implementação de um conjunto normativo que viabilizasse sua execução - os chamados instrumentos urbanísticos numa postura reativa frente aos possíveis efeitos decorrentes da valorização imobiliária gerada pelas outras ações financiadas pelo banco. Se por um lado os Planos Regionais das Subprefeituras Sé e Mooca foram considerados uma regulação urbana que garantiria os investimentos privados na região, como apontado anteriormente; por outro, em conjunto com o Plano Diretor Estratégico e o novo zoneamento da cidade, eles também eram vistos como um conjunto de instrumentos urbanísticos que viabilizariam a produção habitacional para baixa renda na área central. 


\subsection{INSTRUMENTOS URBANÍSTICOS: CONTROLE PÚBLICO OU BENEFíCIO A INTERESSES PRIVADOS?}

Alguns dos instrumentos urbanísticos voltados especificamente para a "revitalização" do centro da cidade de São Paulo foram formulados na década de 1990 com o objetivo de melhorar e transformar seu ambiente construído e a paisagem urbana, mediante a flexibilização da legislação urbanística e da concessão de benefícios fiscais que gerassem o interesse de investidores privados, como apontado no capítulo 2. Recentemente, associados ao sistema de planejamento urbano do município, um conjunto de instrumentos aplicáveis na área central foi instituído pelo Plano Diretor Estratégico (PDE-2002/2012) em 2002 e, dois anos depois, regulamentados pelos Planos Regionais Estratégicos (PRE) e pela nova Lei de Uso e Ocupação do Solo (LUOS). O contexto de aprovação desses planos foi de grande entusiasmo entre alguns grupos de urbanistas, entidades e movimentos sociais organizados, devido à aprovação do Estatuto da Cidade em 2001, que regulamentou o Capítulo da Política Urbana da Constituição de 1988.

A análise dos documentos oficiais do Programa Ação Centro permitiu identificar que muitos de seus componentes e ações seriam realizados a partir da utilização de instrumentos urbanísticos existentes e propostos - cuja formulação enfocou diferentes entendimentos do papel do poder público sobre a produção do espaço urbano, ainda que sob um mesmo discurso argumentativo: "promover o desenvolvimento social e econômico com diversidade da Área Central" (PMSP/EMURB, 2004d). Nesse sentido, apesar de existirem alguns pontos de convergência entre os diversos instrumentos propostos, como veremos nesta seção, pudemos identificar dois grupos distintos, compostos por instrumentos instituídos pelo Plano Diretor de 2002 ou que já existiam e por ele não foram alterados.

O primeiro grupo envolve os instrumentos que foram concebidos a partir das discussões e questões relativas à implementação dos programas de habitação de interesse social na área central, que indicaram a aplicação de determinados mecanismos como fundamental para viabilizar a produção habitacional e garantir a permanência da população de baixa renda na região. Podemos dizer que tais instrumentos tinham como pressuposto o controle público sobre a produção do espaço urbano e também buscavam evitar a retenção especulativa de imóveis e, no limite, procurar conter a valorização fundiária e imobiliária de determinados perímetros da área central, baseando-se na idéia de função social da propriedade.

Já o segundo abarca os instrumentos que foram pensados primordialmente como indutores de uma transformação de uso e ocupação do solo, através de mecanismos que flexibilizassem a legislação urbanística vigente, concedendo incentivos e atraindo o interesse de investidores 
privados, de maneira similar àqueles instrumentos criados na década anterior. Dentro da ótica da retomada econômica que apontamos ao longo desse trabalho, seu pressuposto é que o poder público tenha um papel de promotor da livre iniciativa de setores do capital sobre o desenvolvimento urbano, articulando os diversos atores sociais atuantes e presentes no território, em especial buscando parcerias com o setor privado - incorporadores, investidores, construtores, proprietários, etc.

Nesta seção, buscamos compreender os objetivos dos instrumentos urbanísticos que permearam a proposta de alguns dos componentes do Programa Ação Centro, a partir dos dois grupos identificados acima. Recorremos, portanto, a uma leitura cruzada dos documentos oficiais do programa e dos textos legais que instituíram e regulamentaram os instrumentos - Plano Diretor, Planos Regionais, Lei de Uso e Ocupação do Solo, entre outros.

Antes de prosseguir nessa análise, consideramos necessário abordar brevemente a origem européia do conceito de instrumento urbanístico e como se deu sua inserção recente na problemática urbana brasileira e, especificamente, paulistana.

\subsubsection{ORIGEM DO CONCEITO DE INSTRUMENTO URBANÍSTICO E SUA INTRODUÇÃO NO} BRASIL

O entendimento do conceito de instrumento urbanístico remete à constituição do Estado burguês europeu, como parte das ferramentas necessárias à consolidação e expansão de seu sistema econômico (FERREIRA \& MOTISUKE, 2007). Ao lado das medidas que visavam garantir a reprodução da força de trabalho e regular as relações de trabalho e consumo, o surgimento dos instrumentos urbanísticos estava associado à necessidade de ordenar o espaço urbano, em função da ordem social capitalista em formação. Buscava-se, portanto, qualificar a mão de obra e torná-la disponível às necessidades do capital, dando-lhe melhores condições de vida e uma capacidade aquisitiva suficiente para a constituição de um mercado consumidor, necessário à sobrevivência do próprio capitalismo.

Melhorar a qualidade de vida da mão de obra - o que passa, necessariamente, pela organização do espaço urbano (ou ambiente construído) - significa criar e atender certos padrões de consumo que se desdobram numa ampliação dos direitos do trabalhador e, ao mesmo tempo, servem aos interesses de acumulação do capital. Isso se dá através da ação do Estado, estabelecendo diversos tipos de mecanismos de controle social. Como aponta Harvey (1982, p.19), “a escolha do consumidor é traduzida, da anarquia descontrolada da ação individual, para a área aparentemente mais controlável da ação estatal". 
"Portanto, a sobrevivência do capitalismo requer que o trabalho seja dominado pelo capital, não apenas no processo de trabalho mas também com respeito à própria definição de qualidade de vida na esfera do consumo. A produção (...) não só produz o consumo; ela produz também o modo de consumo, e no final das contas a isto se reduz, evidentemente, o fundo de consumo ${ }^{128}$ para o trabalho (HARVEY, 1982, p.12).

Desse modo, o surgimento de mecanismos reguladores - entre eles os instrumentos urbanísticos - esteve ligado às necessidades do Estado em exercer controle sobre as relações sociais e, portanto, sobre a produção do espaço urbano; papel esse que se constituía essencial para buscar uma resolução à contradição estrutural do modo capitalista de produção. Tal contradição se baseia, por um lado, na exploração da mão-de-obra, "afinal, sem ela a mais-valia não poderia ser extraída e a acumulação desapareceria" (HARVEY, 1982, p.7), e por outro, na necessidade de reprodução dessa força de trabalho, não apenas como mão-de-obra, mas também como massa consumidora, dotando-a de melhores salários e condições de vida. Isso porque o ciclo de reprodução do capital - e, conseqüentemente, a manutenção do sistema econômico capitalista realiza-se mediante a venda da produção. A cada crise do sistema - decorrente dessa contradição estrutural - novos mecanismos de controle e mediação eram criados pelo Estado, como a regulamentação dos diretos trabalhistas que sucedeu a crise de 1929, tanto na Europa como na América do Norte.

Mas foi no período do pós-guerra, em meados do século XX, que os instrumentos urbanísticos ganharam um papel fundamental na constituição de um poder estatal controlador e mediador, contrapondo-se ao laissez-faire da ideologia liberal - a lógica da auto-regulação do mercado - e servindo ao fortalecimento do Estado de Bem-Estar Social europeu (o Estado keynesiano). Seguindo os mesmos objetivos de criar melhores condições de vida aos trabalhadores - dandolhes capacidade de consumo - como forma de garantir a manutenção da ordem social e econômica capitalista, o Estado de Bem-Estar Social estabeleceu certa distribuição de riquezas na sociedade industrial, assumindo papel de mediador entre os interesses do capital e do trabalho e garantindo os direitos fundamentais e universais para o conjunto dos trabalhadores - saúde, educação, direitos trabalhistas.

Ao mesmo tempo, procurava-se "proteger" a cidade do capital imobiliário e especulativo, o que era necessário para a própria acumulação no âmbito da produção do espaço urbano (FERREIRA \& MOTISUKE, 2007). Foram instituídos instrumentos urbanísticos, jurídicos e financeiros que garantiram ao Estado esse poder regulador sobre o desenvolvimento urbano, sobre suas dinâmicas fundiárias e imobiliárias, ainda que em alguns casos envolvessem articulações com

128 O "fundo de consumo", segundo Harvey (1982), se constitui nos elementos do ambiente construído que são utilizados na reprodução da classe trabalhadora, ou seja, na esfera do consumo: habitação, escolas, parques, etc. 
setores da iniciativa privada. A questão habitacional ganhava importância como direito à moradia e equilíbrio no ordenamento do espaço urbano, enfocando, por exemplo, a produção massiva de conjuntos habitacionais de interesse social para suprir a crescente demanda do pós-guerra, tanto pelo poder público como pela iniciativa privada.

Entre os instrumentos urbanísticos formulados - alguns já mencionados ao longo deste trabalho - podemos citar: solo criado; direito de preempção; controles do direito de construir, do uso e ocupação do solo, da valorização imobiliária; estímulos a ações específicas da iniciativa privada, mediante linhas de crédito, isenções e renúncias tributárias; desapropriação para fins de moradia; limite aos valores dos aluguéis; linhas de crédito e subsídios especiais; entre outros.

O conceito de "solo criado", que se baseia na separação entre o direito de propriedade e o direito de construir, foi aplicado pela primeira vez na cidade de Chicago (EUA), através de uma lei aprovada em 1973 com o objetivo de garantir a preservação de edifícios históricos. A lei "plafond legal de densitê" (PLD), implantada a partir de 1975 na França, também se baseou nesse conceito, permitindo o uso de potencial construtivo acima daquele definido pela legislação, mediante pagamento de uma taxa ao governo local. Tinha como objetivo a promoção da reciclagem de construções existentes, a contenção da especulação imobiliária e arrecadação de fundos para os governos locais $^{129}$.

Portanto, através do Estado de Bem-Estar Social - a social democracia européia - criava-se um sistema de controle e indução das ações do mercado imobiliário no processo de produção do espaço urbano, através do ferramental dos instrumentos urbanísticos. Mesmo com o caráter estrutural dessas medidas para a reprodução e acumulação do capital, através da manutenção da ordem social vigente, foi constituída uma tradição intervencionista do poder público sobre o crescimento das cidades e o desenvolvimento urbano, tentando mediar os conflitos de interesses inerentes ao processo de produção do espaço e buscando sobrepor o interesse público ao privado, ainda que dentro dos limites impostos pelo próprio capitalismo.

Já no Brasil, a defesa pelo controle público sobre a produção do espaço urbano vinha sendo construída desde antes do golpe militar de 1964. Segundo Maricato \& Ferreira (2001), “já em 1963, o Seminário Nacional de Habitação e Reforma Urbana se propôs a buscar caminhos para parametrizar o crescimento das cidades que começava a se delinear". Com a ditadura militar, porém, a mobilização da sociedade em torno dessa defesa foi desmontada, sendo retomada

129 Alguns trabalhos apresentam históricos e análises sobre esse conceito e os instrumentos que foram criados a partir dele: LABHAB/LILP/CAIXA (2006); Nobre (2000); Van Wilderode (1994), Del Rio (1991). 
somente com o processo de abertura política no final dos anos 1970, trazendo a questão novamente à tona através da organização de movimentos sociais urbanos.

Diante das demandas e problemáticas das cidades brasileiras e seguindo os mesmos princípios dos instrumentos urbanísticos europeus do pós-guerra - depois difundidos também na América do Norte - formava-se o Movimento de Luta pela Reforma Urbana, que conseguiu articular diversos grupos sociais na Assembléia Constituinte de 1988, aprovando a emenda popular do Capítulo da Política Urbana (art. 182 e 183) na Constituição Federal aprovada no mesmo ano. No bojo da democratização política, era reivindicado que o Estado tivesse um controle efetivo sobre a produção do espaço urbano, através de mecanismos que invertessem a lógica desigual e os processos segregacionistas de expansão urbana.

Por essa emenda popular foi introduzida a idéia de função social da propriedade, com base na definição de solo urbano não edificado, subutilizado ou não utilizado. Também foram instituídos alguns instrumentos urbanísticos que deveriam ser aplicados pelos governos municipais, de forma sucessiva, para induzir ao cumprimento da função social: (i) parcelamento ou edificação compulsórios; (ii) imposto sobre a propriedade predial e territorial urbana progressivo no tempo; e (iii) desapropriação com pagamento mediante títulos da dívida pública.

No entanto, sua efetivação estava atrelada à regulamentação de uma lei federal específica e, no caso de municípios com mais de 20 mil habitantes, à elaboração de Planos Diretores. Diante dessa exigência, foi encaminhado ao Congresso Nacional um projeto de lei (PL 5.788/1990) para regulamentar o Capítulo da Política Urbana, iniciando um longo processo de luta e discussões que culminou na aprovação do Estatuto da Cidade (LF 10.257/2001), quando foi instituído um amplo conjunto de instrumentos urbanísticos ${ }^{130}$. Nessa lei (art. 41) foi mantida a obrigatoriedade de elaborar Planos Diretores, criando os parâmetros locais de ordenamento do crescimento urbano e de aplicação de seus instrumentos, mas ampliando a exigência para as cidades localizadas em áreas metropolitanas, de interesse turístico etc., independente do número de habitantes - além daquelas com mais de 20 mil habitantes - dentro de um prazo de 5 anos.

130 Vale lembrar que, mesmo antes da aprovação do Estatuto da Cidade, algumas cidades brasileiras vinham experimentando a aplicação de instrumentos urbanísticos, como é o caso da própria cidade de São Paulo. O conceito de "solo criado" foi introduzido aqui ainda na gestão Mario Covas (1983-1985), pela lei de transferência do potencial construtivo, sendo posteriormente retomado e aplicado durante a gestão Jânio Quadros (1986-1989) através das Operações Interligadas. Na década de 1990, esse conceito também norteou os principais mecanismos das Operações Urbanas Anhangabaú e Centro (outorga onerosa do direto de construir e transferência do potencial construtivo). As Zonas ou Áreas Especiais de Interesse Social (ZEIS ou AEIS) também tiveram implementações pioneiras em algumas cidades, como é o caso de Diadema, que aplicou o instrumento em áreas vazias a fim de viabilizar a produção de moradia social, e o caso de Recife, que delimitou ZEIS em favelas com o objetivo de realizar a urbanização das áreas. 
Apesar de não possibilitar a aplicação imediata de seus dispositivos, a aprovação do Estatuto da Cidade representou um avanço da política urbana brasileira, construindo um cenário promissor para a luta pela reforma urbana, pelo direito à cidade e à moradia, com vistas a um desenvolvimento urbano democrático e igualitário, inclusive para ações de recuperação de áreas centrais. Em 2003, com a criação do Ministério das Cidades, foi iniciada uma campanha pela elaboração dos Planos Diretores, com base nos instrumentos do Estatuto e na participação popular; o que foi chamado de "Campanha Nacional Plano Diretor Participativo: cidade de todos” (BRASIL/MINISTÉRIO DAS CIDADES, 2005, p.20).

\footnotetext{
Começava a se delinear a possibilidade de um novo ciclo de mudanças nos setores de urbanismo das administrações das cidades brasileiras. A intensidade dos debates em torno da questão urbana, a emergência de experiências de gestão voltadas para a politização da prática urbanística, para o rompimento da barreira entre quem pensa e quem executa, e a formulação de novos instrumentos de gestão do uso do solo, são indicadores de que um novo saber urbanístico, novas práticas e um perfil de profissional urbanista estão em processo de construção (FELDMAN, 2005, p.284).
}

Em 2002, nesse contexto de entusiasmo, muitos dos instrumentos urbanísticos instituídos pelo Estatuto da Cidade foram inseridos e regulamentados no Plano Diretor Estratégico do Município de São Paulo (LM 13.430/2002) e, em 2004, detalhados nos Planos Regionais Estratégicos no âmbito da descentralização administrativa e de criação das Subprefeituras. Esses últimos foram aprovados em conjunto com a nova Lei de Uso e Ocupação do Solo (LM 13.885/2004) - novo zoneamento da cidade. Além do direito à cidade, envolvendo a ampliação do acesso à terra urbana e à moradia, diversos princípios e conceitos nortearam a formulação de instrumentos urbanísticos, buscando uma forma politizada de fazer planejamento urbano. Destacam-se alguns que foram listados no Estatuto da Cidade $\left(\operatorname{art.} 2^{\circ}\right)$ e no Plano Diretor $\left(\operatorname{art.~} 7^{\circ}\right.$ e $\left.8^{\circ}\right)$ :

i) Gestão democrática das cidades, que poderia se dar através de audiências públicas, do orçamento participativo, da criação de conselhos paritários, entre outros;

ii) Cooperação entre diversas instâncias e níveis de governo;

iii) Participação da iniciativa privada no processo de urbanização, através de diversos instrumentos urbanísticos, quando for de interesse público (como as Operações Urbanas Consorciadas);

iv) Transferência para a coletividade de parte da valorização imobiliária inerente à urbanização;

v) Justa distribuição dos benefícios e ônus do processo de urbanização;

vi) Racionalização do uso da infra-estrutura urbana instalada, evitando sobrecarga ou ociosidade; e 
vii) Garantia da função social da cidade e da propriedade, evitando distorções e abusos no desfrute econômico da propriedade e coibindo sua retenção especulativa.

No entanto, mesmo que diante de um importante marco legal da política urbana brasileira, cabe destacar que sua introdução e regulamentação no Brasil ocorreram num contexto históricoestrutural completamente diferente do europeu, em que a tradição do controle público sobre o urbano nunca se configurou como forma de sobrepor os interesses públicos/coletivos aos privados/individuais. A estruturação de uma sociedade "desigual e combinada", que manteve suas estruturas e relações "arcaicas" mesmo dentro de um modo de acumulação "moderno" industrial (OLIVEIRA, 2003), servindo à manutenção de privilégios, está na base da formação do Estado brasileiro, impedindo a constituição de um Estado forte, necessário à inversão da lógica segregacionista do processo de produção do espaço urbano. Partindo do entendimento de que nunca se completou a formação de um Estado de Bem-Estar Social brasileiro (OLIVEIRA, 2003), os instrumentos urbanísticos teriam um papel de "reverter a posteriori um processo histórico-estrutural de segregação espacial", dando "ao Estado a capacidade de enfrentar os privilégios urbanos adquiridos pelas classes dominantes ao longo de sua hegemônica atuação histórica de 500 anos" (FERREIRA, 2003).

Ainda assim - e numa tarefa hercúlea, diga-se de passagem - a proposição de uma política habitacional enfocando áreas urbanas consolidadas (centrais) e visando contribuir para a reversão da lógica de expansão periférica e segregacionista da metrópole paulistana, deu-se de acordo com muitos dos princípios e conceitos citados anteriormente. Associava-se às reivindicações de mais de uma década dos movimentos de moradia do centro e retomava as discussões sobre a habitação social no centro que haviam sido iniciadas durante a gestão Luiza Erundina.

No entanto, como já abordado, a transformação das propostas do campo habitacional - Morar no Centro - em um dos componentes do Ação Centro, vinculou ao âmbito do financiamento do BID a montagem dos programas habitacionais - gerando embates, como vimos - e as discussões sobre a formulação dos instrumentos urbanísticos voltados para a produção de moradia social no centro. Essas discussões consideraram fundamental a criação de mecanismos que viabilizassem a produção habitacional na área central (PMSP/SEHAB, 2004b); debates esses que ocorreram em conjunto com a elaboração do Plano Diretor Estratégico (PDE) e dos Planos Regionais Estratégicos (PRE). Tinha-se uma expectativa com relação a esses mecanismos, no sentido de possibilitarem ao poder público municipal um controle sobre a produção do espaço urbano, garantindo uma ocupação democrática da área central. 
Ao mesmo tempo, o Programa Ação Centro apresentou um outro entendimento sobre os mecanismos que estavam em discussão, considerando os PRE da Sé e da Mooca como "marco regulador estável" para que os investidores imobiliários voltassem a se interessar pela área central, investindo não apenas em usos residenciais, mas também em atividades do setor terciário,

inclusive "com instalações de última geração" (SOMEKH, 2004b, p.2; BID, 2004a, p.11). Neste caso, a expectativa era que a legislação urbanística regulamentada pelos Planos Regionais viabilizasse os objetivos do programa de tornar a área central atraente para os investimentos privados, "alavancando" transformações no perfil de uso e ocupação do solo e alcançando a recuperação da área, com sua redinamização econômica e valorização imobiliária. No Marco Lógico do programa também foi apontado que esses planos seriam uma condição para que fossem alcançados os resultados do componente "Reversão da Desvalorização Imobiliária e Recuperação da Função Residencial”

\subsubsection{Planos Regionais Sé e Mooca: QUal importânCia para o AÇão Centro?}

De maneira geral, percebe-se uma correlação entre as propostas do Programa Ação Centro e as disposições dos Planos Regionais Estratégicos (PRE) da Mooca e da Sé, especialmente do último. Vale lembrar que o Ação Centro foi aprovado pelo BID um ano antes da regulamentação dos PRE pela Câmara Municipal, o que nos leva a entender que o primeiro não se subordinou às recomendações do segundo, como se esses fossem "cartas magna” para os programas e projetos urbanos. Parece-nos, isso sim, que ocorreu o contrário.

É possível perceber tal correlação através de referências diretas a ações e subcomponentes do Ação Centro, feitas ao longo de todo o texto dos PRE, em especial no da Sé. Entre eles destacamos as citações ao Programa Ruas Comerciais; à Trilha Histórica; às obras dos piscinões na Praça 14 Bis e das Bandeiras; aos melhoramentos viários (como a complementação da contrarótula); à proibição do uso de calçadas localizadas dentro da contra-rótula como ponto final (condizente com a diminuição das linhas de ônibus que convergem ao centro); ao estímulo à implantação de garagens subterrâneas na área interna à contra-rótula; ao Corredor Cultural; e ao projeto do Parque Dom Pedro II, incluindo a criação do Museu da Cidade, a reforma do Mercado Municipal, entre outros. Mais ainda, os textos de ambos os planos indicaram a implementação do programa entre seus "objetivos de desenvolvimento urbano e ambiental" (PRE Sé art. $2^{\circ}$, inciso VII; PRE Mooca art. $3^{\circ}$, inciso IV). O PDE, não mencionou o Ação Centro, mas apontou entre suas ações estratégicas para o desenvolvimento urbano, a necessidade de "requalificar o Centro Histórico e seu entorno, destacando a Várzea do Carmo, o Parque 
Dom Pedro, a região do Mercado Municipal, da Rua 25 de Março e adjacências, a zona cerealista e o entorno da Estação da Luz" (PDE, art.78, inciso VI).

Importante destacar, porém, que foram estabelecidas diferenças marcantes quanto às intenções do programa para cada um dos territórios. Para a Subprefeitura Sé foi indicado que a "recuperação do ambiente urbano, em especial das áreas degradadas" se daria através do "incremento das atividades de zeladoria, da requalificação de edifícios de interesse histórico, do controle de inundações e do tratamento de resíduos sólidos"; enquanto que na Mooca essa recuperação ocorreria apenas por meio de uma "zeladoria especial". Além disso, um dos objetivos para o território da Subprefeitura Sé seria a "reversão da desvalorização imobiliária e a recuperação da função residencial" - mesmo nome dado a um dos componentes do programa enquanto no PRE da Mooca constou apenas o segundo item. Outros objetivos relativos ao programa apareceram em ambos os planos: "melhoria da circulação e dos transportes" e “transformação do perfil econômico por meio de ações que induzam o fomento à pluralidade econômica, a inclusão social, a segurança urbana e o fomento à cultura" (PRE Sé, art. $2^{\circ}$, inciso VII; PRE Mooca, art. $3^{\circ}$, inciso IV).

Essas diferenças refletem, a nosso ver, o tratamento dado para as distintas áreas de atuação do Programa Ação Centro: a focalização de suas ações na Área de Interesse (distritos Sé e República), localizada no território da Subprefeitura Sé; a importância dada ao Parque Dom Pedro II e seu entorno, na divisa entre as duas Subprefeituras; e os distritos de seu entorno, onde se localizaram a maioria dos programas habitacionais. Dessa forma, as disposições do PRE Sé se alinharam muito mais aos objetivos do programa do que as do PRE Mooca.

Curioso atentar para o fato de que, em conjunto com o Ação Centro, a Operação Urbana Centro e o Programa Monumenta BID-LUZ - este último em cooperação com o Governo do Estado e o Ministério da Cultura - foram apresentados no Plano da Sé como mecanismos para promover o desenvolvimento urbano e ambiental da região central. Enquadraram-se naquilo que foi definido como "instrumento de Intervenção Urbana Regional Estratégica", nas diretrizes gerais das "políticas públicas regionais", no capítulo específico sobre a Região Centro, constantes na lei que regulamentou os planos regionais e a Nova Lei de Uso e Ocupação do Solo (LUOS).

São definidos como instrumentos de Intervenções Urbanas Regionais Estratégicas aqueles que promovem transformações urbanísticas numa determinada área, cujos resultados se irradiam para uma área envoltória mais abrangente, promovendo o desenvolvimento da região... (Lei Municipal 13.885/2004, art. 92, grifos nossos)

Nos demais objetivos das políticas públicas regionais do PRE Sé (título I, art. $1^{\circ}$ a $5^{\circ}$ ), nota-se uma ambigüidade de princípios e diretrizes, da mesma maneira que ocorre com o Programa Ação 
Centro. Entre os objetivos foi explicitado tanto o intuito de "estimular a instalação de atividades diversificadas de alta tecnologia, de atração nacional e internacional, reforçando o papel de centro metropolitano e de cidade mundial ${ }^{131}$ " (art. $2^{\circ}$ ); quanto o de "atender a população moradora de cortiços e favelas" (art. $2^{\circ}$ ), de "ampliar a oferta de habitação de interesse social" (art. $3^{\circ}$ ) e de "assegurar o direito à moradia digna para população de baixa renda" (art. $4^{\circ}$ ). A mesma contradição aparece no capítulo específico sobre a Região Centro da lei dos Planos Regionais e da LUOS (LM 13.885/04, parte II, art. 89 a 92).

Se por um lado as disposições do PRE Sé indicaram a necessidade de melhorar a condições de vida da população de baixa renda moradora dos bairros centrais, mediante o acesso à moradia digna e a produção de habitação social, por outro, utilizou o discurso corrente da "cidade-global", visando atrair investimentos, inclusive a instalação de atividades de alta tecnologia. Assim como a definição de Intervenção Urbana Regional Estratégica, a atração de investimentos privados para o centro necessitaria de projetos tipo "alavanca", em geral realizados com recursos públicos, que iniciassem o processo de transformação e desenvolvimento da área. Esse tipo de processo, por sua vez, tem resultado em considerável valorização imobiliária e substituição do perfil sócioeconômico das atividades e da população moradora e usuária, como visto nos exemplos internacionais mencionados anteriormente. Questionamo-nos, portanto, o quanto o aumento da oferta de habitação de interesse social será possível se conjugado aos objetivos de "reforçar o papel de cidade mundial" a que se refere o texto do PRE Sé.

Além desses objetivos gerais, os PREs também indicaram a aplicação de alguns dos instrumentos urbanísticos instituídos pelo PDE. Destacamos nessa seção as Operações Urbanas Consorciadas e as Áreas de Intervenção Urbana (AIU), por corresponderem a áreas que foram indicadas pelo Programa Ação Centro para "projetos motores".

As AIU foram propostas como "porções do território de especial interesse para o desenvolvimento urbano, objeto de projetos urbanísticos específicos", onde poderiam ser “aplicados instrumentos de intervenção, previstos (...) no Estatuto da Cidade" (PDE, art. 146, inciso VI), sendo que para alcançar seus objetivos, poderiam ser realizadas "parcerias com os demais níveis de governo e com o setor privado" (PDE, art. 221, $\int 5^{\circ}$ ). Entre seus diversos objetivos, podemos destacar: execução de programas de habitação de interesse social; constituição de reserva fundiária; ordenamento da expansão urbana; implantação de

\footnotetext{
131 Vale destacar que o PDE, em seu artigo 15, incisos III e IV, indicou como uma das diretrizes de desenvolvimento econômico e social "o desenvolvimento de relações nacionais e internacionais com associações e instituições multilaterais", bem como "o fomento a iniciativas que visem atrair investimentos, públicos ou privados, nacionais e estrangeiros".
} 
equipamentos, espaços públicos; e criação de unidades de conservação ou proteção ambiental. Ainda segundo o PDE, deveriam ser delimitadas AIUs em eixos e estações de transporte público, em fundos de vale e/ou em eixos e pólos de centralidade (art. 122, 126, 221 a 224).

Entre as diversas AIU delimitadas pelos dois Planos Regionais vale citar duas na Mooca (PariBrás e Parque Dom Pedro II) e cinco na Sé (Parque Dom Pedro II e Glicério, Pari-Brás, Programa Monumenta-BID-Luz e PRIH-Luz, Quadrilátero Piloto ${ }^{132}$, e Foz do Tamanduateî). As três últimas da Sé foram consideradas PEIU - Projetos Estratégicos de Intervenção Urbana, uma modalidade de AIU, de acordo com o artigo 221 do PDE. Todas elas envolveram diretrizes e projetos correlatos ao que foi proposto pelo Ação Centro, especialmente no que se refere à melhoria do ambiente urbano e a estímulos que deveriam ser dados a proprietários, locatários e investidores, como no caso do PIU do Quadrilátero Piloto (PRE Sé, art. 44, inciso VIII).

Para a AIU Pari-Brás da Mooca, o plano se referia à "implantação da nova ligação viária que circunda o nó central criando a nova rótula a nordeste, a desembocar na região da Luz" (parte das complementações viárias listadas no Ação Centro), a partir da qual se daria uma "renovação completa do setor" Pari-Brás (PRE Mooca, art. 51). Ou seja, uma intervenção viária - com recursos públicos - que "alavancaria” as transformações urbanas do entorno.

A denominação comum entre algumas AIUs das duas Subprefeituras parece não ser causal, mas sim, decorrente de projetos que se complementam. Pode-se notar essa complementaridade nas AIUs Parque Dom Pedro, com a área da Sé localizada na porção oeste do parque, estendendo-se até a baixada do Glicério, e a área da Mooca na porção leste. Muitos de seus objetivos eram similares, fazendo referência direta aos projetos propostos pelo Programa Ação Centro, os quais ganharam importância dentro do financiamento do BID, como vimos no capítulo 1. Por essa razão, destacamos na seqüência os objetivos e diretrizes dessas duas AIUs.

O objetivo proposto para a AIU Parque Dom Pedro II/Glicério do PRE da Sé era a “recuperação e reabilitação da várzea do Rio Tamanduater" e para a AIU da Mooca era "uma renovação completa do setor". Integraram os objetivos de ambas as AIUs os projetos constantes do escopo do Ação Centro, a saber: reurbanização do Parque Dom Pedro II; criação do Museu da Cidade no edifício do Palácio das Indústrias; restauro da Casa das Retortas; reforma do Mercado Municipal; recuperação dos viadutos 25 de Março e Glicério; e melhorias do sistema viário (PRE Sé, art. 44, inciso II; PRE Mooca, art. 55). ${ }^{132}$ No texto do PRE Sé essa área não foi denominada como “Quadrilátero Piloto", no entanto, corresponde ao mesmo
perímetro, como pode notado pela comparação entre o mapa 1 deste trabalho e o texto do PRE Sé (PRE Sé, art. 44, inciso VIII). 
Nas duas AIUs também foi apontada a intenção de reabilitar/renovar imóveis para serem destinados ao uso habitacional, com unidades para rendas média e baixa. Para a AIU da Mooca o estímulo ao uso habitacional deveria enfocar as Zonas Especiais de Interesse Social (ZEIS) localizadas no Glicério e no Brás - áreas que coincidiam com os perímetros do programa dos Perímetros de Reabilitação Integrada do Habitat (PRIH), integrante do Morar no Centro.

As diretrizes das duas AIUs envolviam a recuperação do patrimônio histórico, incluindo os edifícios citados acima, e a readequação dos espaços públicos, "principalmente quanto à presença dos ambulantes" (PRE Mooca, art. 56; PRE Sé, art. 44, inciso II). Para a área da Sé foi estabelecido maior número de diretrizes, também se referindo a projetos do Ação Centro: (i) reurbanizar a Rua 25 de Março; (ii) aplicar a Lei de Incentivos Seletivos - atração de empresas mediante isenções fiscais e tributárias; (iii) priorizar o atendimento habitacional na área dos PRIH; (iv) melhorar a infra-estrutura existente diante do "novo potencial construtivo da área"; (v) melhorar os espaços públicos; e (vi) instituir fundo público para a realização de estudos de viabilidade técnica e sócio-econômica de recuperação de edifícios deteriorados (tecnologia e projetos); (vii) adotar o instrumento do Consórcio Imobiliário para a reabilitação dos edifícios, em que o poder público pode receber imóvel de terceiro, a fim de dar-lhe melhor aproveitamento, sendo que seu proprietário receberá como pagamento, unidades imobiliárias urbanizadas ou edificadas, correspondentes ao valor do imóvel antes da execução das obras; e (viii) dar prioridade ao Programa Ação Centro, especificamente nas áreas do triângulo histórico, do Corredor Cultural, do próprio Parque Dom Pedro II, da zona cerealista/25 de Março e da Praça da Sé/Praça João Mendes.

Parece, portanto, que o texto dos planos regionais da Sé e da Mooca, contemplou exatamente aquilo que foi determinado no escopo do Ação Centro. Os planos incluíram as mesmas intervenções e, acreditamos, os mesmos objetivos de melhorar o ambiente urbano, a fim de dar condições aos novos investimentos privados que se desejava atrair. Por outro lado, também listou diretrizes relativas à Habitação de Interesse Social (HIS), às ZEIS e aos PRIHs incorporando os objetivos e subprogramas do Morar no Centro, como veremos mais adiante.

Para todas as AIU e PEIU, a lei dos Planos Regionais estabeleceu que poderiam ser propostos índices e parâmetros urbanísticos diferentes daqueles definidos na lei de zoneamento, desde que elaborada uma lei específica e considerando um coeficiente de aproveitamento (CA) máximo até 4 vezes a área do lote. Tal lei deveria determinar objetivo, finalidade e perímetr"o de abrangência dos projetos; aplicação da outorga onerosa de potencial construtivo adicional, da transferência do direito de construir e demais instrumentos urbanísticos; estoque de potencial construtivo, 
definido com base nos estudos técnicos de capacidade da infra-estrutura de circulação; e mudanças desejadas no parcelamento, uso e ocupação do solo (Lei Municipal 13.885/2004, art. $35)$.

MAPA 6: INSTRUMENTOS URBANÍSTICOS DO PDE E DO PRE NA ÁREA CENTRAL

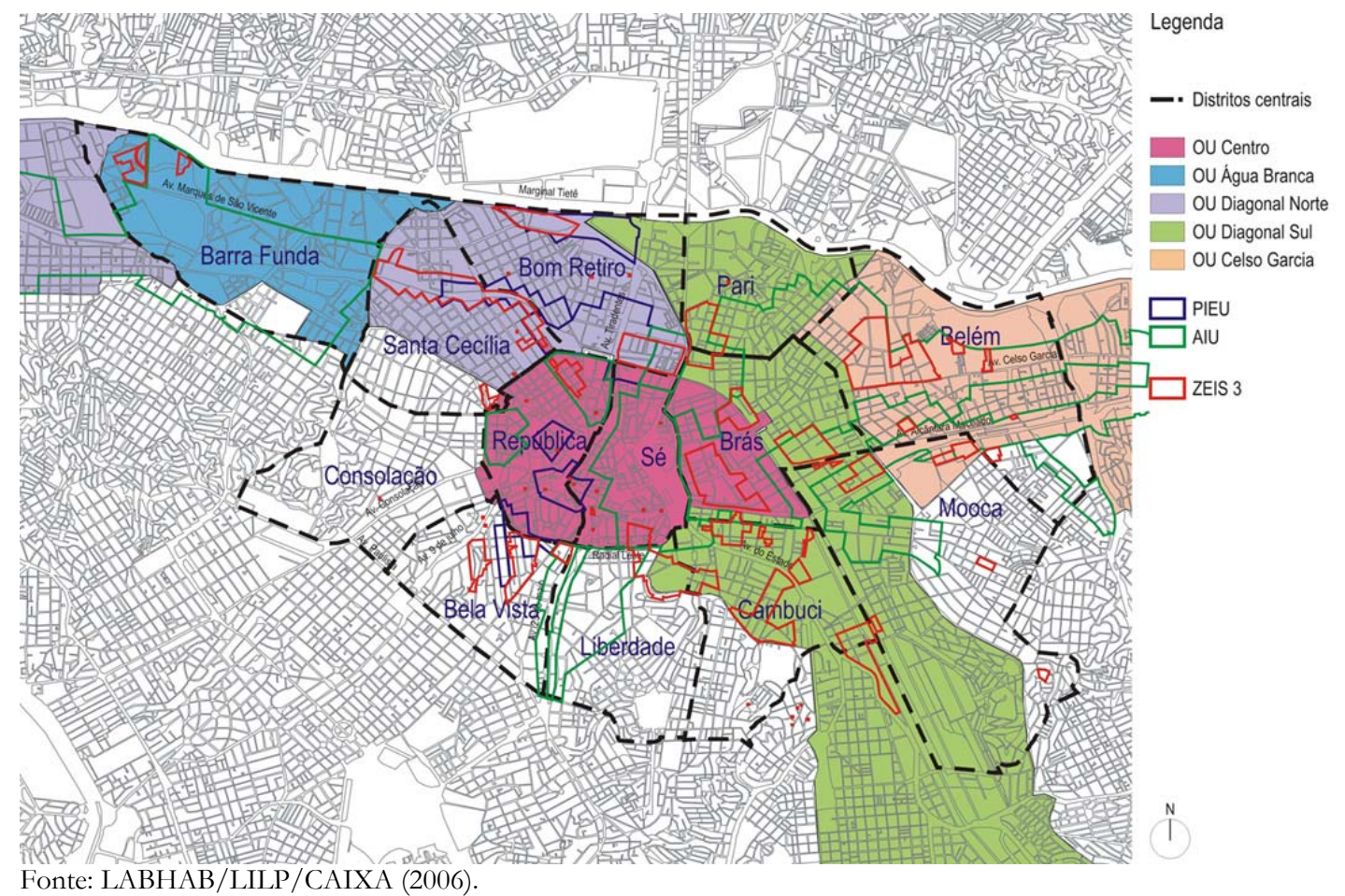

Apesar de listar uma série de dispositivos, possibilidades de intervenção e obrigações para as AIU e PEIU, o texto da lei afirma que nos casos em que ocorrer sobreposição com uma Operação Urbana Consorciada, prevalecerá o que foi estabelecido na lei específica dessa última. Conforme mapa 6, onde estão delimitados os instrumentos urbanísticos incidentes na área central, podemos notar que há uma considerável sobreposição, sendo que a maioria das AIU e PEIU foi delimitada em áreas de Operação Urbana. Ou seja, ao final, vale os dispositivos das Operações Urbanas, desde que essas tenham lei específica regulamentada.

As Operações Urbanas Consorciadas, instituídas pelo Estatuto da Cidade, foram definidas no Plano Diretor e nos Planos Regionais para diversas regiões do município, mas sua aplicação depende de legislação específica. Em seu artigo 255, o PDE definiu as Operações Urbanas Consorciadas da seguinte forma, com base no Estatuto:

As Operações Urbanas Consorciadas são o conjunto de medidas coordenadas pelo Município com a participação dos proprietários, moradores, usuários permanentes e investidores privados, com o objetivo de alcançar transformações urbanísticas estruturais, melhorias sociais e a valorização ambiental, notadamente ampliando os espaços públicos, 
organizando o transporte coletivo, implantando programas habitacionais de interesse social e de melhorias de infra-estrutura e sistema viário, num determinado perímetro. (Lei Municipal 13.430/2002, art. 255).

Para a área central os planos contemplaram as seguintes operações: Água Branca, Centro, Diagonal Sul, Diagonal Norte e Celso Garcia, sendo que as duas primeiras estão em vigor desde 1995 e 1997, respectivamente, já possuem leis específicas e foram mantidas pelo Plano Diretor. Além da Operação Urbana Centro, que incide sobre a Área de Interesse do Programa Ação Centro, destaca-se a Operação Urbana Diagonal Sul, que ganhou atenção especial no programa, contemplando a contratação de estudos com recursos do financiamento do BID - estudos urbanísticos/parte 1 e Plano-referência de intervenção e ordenação urbanística (PRIOU). A importância da Diagonal Sul foi ressaltada nos textos do Ação Centro, e também nos planos regionais, através da indicação de uma "forte relação de interação" entre as dinâmicas presentes na área dessa operação e aquelas presentes no centro da cidade, que se encontram "em vias de ampla e profunda redefinição de significado" (SALES, 2004, p.3).

Apesar de englobar parte do território da Subprefeitura Sé, as diretrizes indicadas para a elaboração de sua lei específica constaram apenas no PRE da Mooca, enfocando questões ambientais e paisagísticas (art. 59). Esse PRE também destacou (art. 46) que na área da Diagonal Sul poderia ser aplicada a Outorga Onerosa do Direito de Construir, instrumento que permite ao proprietário construir acima de um coeficiente de aproveitamento básico (CA), até um coeficiente máximo, mediante pagamento de contrapartida financeira à Prefeitura. A idéia é flexibilizar a legislação e conceder benefícios urbanísticos aos investidores, visando atrair seu interesse pelas áreas. Enquanto não regulamentada por lei específica, o PRE da Mooca definiu que o CA máximo da Diagonal Sul deveria ser igual ao permitido na zona onde se localiza, diferente das demais Operações Urbanas, que poderiam considerar um CA máximo igual a 4 (PDE, art. 226) o que pode chegar a 6 na Operação Centro, de acordo com sua lei especifica (Lei Municipal 12.350/1997).

No PDE (art. 227 e 229) foi definido que nas Operações Urbanas Consorciadas deveriam ser realizados empreendimentos e intervenções que contribuíssem ou permitissem ao poder público arrecadar recursos para: implantação de equipamentos; otimização e reciclagem de áreas consideradas subutilizadas; implantação de programas habitacionais; melhoria da rede de transportes e da rede viária; implantação de espaços públicos; preservação do patrimônio histórico; dinamização de áreas visando à geração de empregos. Ou seja, assim como nas operações já implementadas na cidade, a Prefeitura deveria estimular a realização de empreendimentos privados que se utilizassem do instrumento da Outorga Onerosa, visando 
captar recursos a serem destinados a obras e serviços de interesse público. Esta estratégia condiz com um princípio que permeia diversos capítulos do PDE, entendido como "progressista" quanto ao papel do Estado sobre a produção do espaço urbano: a idéia de "recuperar os investimentos públicos que resultem na valorização imobiliária" e garantir uma "justa distribuição dos benefícios e ônus do processo de urbanização", como no artigo 77.

A partir do PDE, as Operações Urbanas Consorciadas passaram a contar com o Certificado de Outorga Onerosa de Potencial Construtivo Adicional (CEPAC), um título que pode ser emitido em certa quantidade correspondente ao valor do estoque de potencial construtivo existente em determinada área (Operação Consorciada, Área de Intervenção Urbana, distrito, etc.). A emissão desses títulos não precisa estar vinculada a um projeto de edificação aprovado, mas deve ser lançados dentro de uma Operação Urbana Consorciada regulamentada em lei específica. Esta certidão também pode ser emitida através do instrumento da Outorga Onerosa do Direito de Construir, que no Plano Diretor foi ampliado para diversas áreas da cidade, deixando de ser restrito às áreas de Operação Urbana.

Algumas análises já foram elaboradas a respeito dos CEPACs enquanto instrumento de arrecadação para o poder público, mostrando questões polêmicas quanto à utilização das "fórmulas mágicas" (FIX, 2000) da parceria público/privado como forma de viabilizar investimentos públicos, nos moldes das operações urbanas já implementadas em São Paulo. Ferreira \& Fix (2001) apontam que "como qualquer um pode comprar o título, tendo ou não lote na região [onde foi lançado], e seu valor - como com qualquer título financeiro - pode variar, gera-se um novo tipo de especulação imobiliária, 'financeirizada"'. Ao mesmo tempo, a Prefeitura deveria criar o maior número de Operações Urbanas possível, atraindo o interesse da iniciativa privada em investir e comprar CEPACs, o que provavelmente exigiria um montante considerável de investimentos públicos prévios para tornar a área em questão atraente e, conseqüentemente, valorizar os CEPACs correspondentes.

Dessa forma, nota-se que a delimitação de Operações Urbanas e AIU, possibilitando a aplicação de instrumentos urbanísticos que visam a realização de parcerias do poder público com a iniciativa privada - nos moldes do planejamento estratégico - ocorreu de forma condizente com os objetivos do Programa Ação Centro quanto à reabilitação da área central, em especial para a Área de Interesse e a região do Parque Dom Pedro - realizar intervenções públicas estratégicas que induzam as transformações de usos, atraindo atividades econômicas "compatíveis com o centro reabilitado", inclusive do "setor terciário de alta tecnologia" (SOMEKH, 2004b, p.4). Se tomarmos como referência as operações implantadas em outras regiões da cidade, como aquelas 
nas proximidades da Marginal Pinheiros - Faria Lima e Água Espraiada - cujos mecanismos têm permitido consideráveis ganhos aos investidores privados (NOBRE, 2000; FIX, 2000; FERREIRA, 2007), receamos que o mesmo possa vir a ocorrer no centro, gerando valorização imobiliária e substituição da população de baixa renda por grupos de maior poder aquisitivo. Como apontam Maricato \& Ferreira (2001), “as Operações Urbanas, por exemplo, que estabelecem a possibilidade de parcerias entre o Poder Público e a Iniciativa Privada na urbanização da cidade, podem tanto trazer benefícios à sociedade como reafirmar o primado absoluto do mercado, conforme forem definidos".

\subsubsection{INSTRUMENTOS URBANÍSTICOS DO PDE E DO PRE E POLÍTICA HABITACIONAL}

Os principais mecanismos instituídos pelo Plano Diretor Estratégico de São Paulo foram os instrumentos de indução ao cumprimento da função social da propriedade, esta entendida como elemento constitutivo do direito de propriedade ${ }^{133}$ : (i) parcelamento, edificação e utilização compulsórios; (ii) Imposto Predial e Territorial Urbano (IPTU) progressivo no tempo; e (iii) desapropriação com pagamento em títulos da divida pública. Como apontou Villaça (2005, p.27), eles que "constituem os grandes avanços do Estatuto [da Cidade]. Muito mais do que os dispositivos associados ao controle do uso e ocupação do solo como a Outorga Onerosa, a Transferência do Direito de Construir, as Operações Urbanas Consorciadas”.

Esses instrumentos foram associados ao princípio de correção das deseconomias urbanas aumentar a eficiência econômica da Cidade $\left(\right.$ art. $8^{\circ}$ ) - que permeou todo o texto do PDE e dos PRE. A idéia era otimizar o aproveitamento da capacidade da infra-estrutura instalada e dos investimentos urbanos coletivos já realizados, evitando sua ociosidade ou sobrecarga, reduzindo seus custos e os deslocamentos (PDE, art. 76). Algumas diretrizes e ações estratégicas das políticas de desenvolvimento urbano do PDE também refletiram esses princípios: estimular a reestruturação e requalificação urbanística de áreas consolidadas e dotadas de infra-estrutura, revertendo os processos de esvaziamento populacional ou imobiliário, através da atração de investimentos, da reciclagem de edifícios existentes, da promoção da diversidade de usos e, ao mesmo tempo, evitando a expulsão de moradores de baixa renda (art. 77). A própria requalificação do centro da cidade se enquadra nesses princípios (art. 78).

\footnotetext{
133 Tsukumo (2007) elaborou estudo sobre o conceito da função social da propriedade, a partir de autores que tratam do direito urbanístico, mostrando que há polêmicas quanto a esse entendimento, uma vez que alguns juristas consideram a função social como elemento limitador ao direito de propriedade.
} 
Como vimos anteriormente, esses princípios e diretrizes de intervenção estiveram presentes nas experiências estrangeiras que denominamos "intervenção na cidade existente", como a Reabilitação Integrada de Lisboa. Buscava-se, entre outros, repovoar os bairros centrais que passavam por processo de esvaziamento e reverter a tendência de expulsão da população de baixa renda e periferização urbana.

Para o cumprimento da função social o PDE definiu o conceito de solo urbano não utilizado, subutilizado ou não edificado, em seu artigo 201 (parágrafos $1^{\circ}, 2^{\circ}$ e $4^{\circ}$ ):

São considerados solo urbano não edificado, terrenos e glebas com área superior a $250 \mathrm{~m}^{2}$, onde o coeficiente de aproveitamento utilizado é igual a zero (PDE, art.201, $\sqrt{ }{ }^{\circ}$ );

São considerados solo urbano subutilizado, os terrenos e glebas com área superior a 250 $\mathrm{m}^{2}$, onde o coeficiente de aproveitamento não atingir o mínimo definido para o lote na zona onde se situam (PDE, art.201, $₫ 2^{\circ}$ );

É considerado solo urbano não utilizado todo tipo de edificação nos distritos da Sé, República, Bom Retiro, Consolação, Brás, Liberdade, Cambuci, Pari, Santa Cecília e Bela Vista que tenham, no mínimo, $80 \%$ (oitenta por cento) de sua área construída desocupada há mais de cinco anos, ressalvados os casos em que a desocupação decorra de impossibilidades jurídicas ou resultantes de pendências judiciais incidentes sobre o imóvel (PDE, art.201, $\sqrt{ } 4^{\circ}$ ).

No sentido de evitar os "abusos no desfrute econômico da propriedade privada e coibir o uso especulativo da terra como reserva de valor" (art. $8^{\circ}$, inciso XI), o PDE declarou que "não cumprem a função social da propriedade urbana, (...) terrenos ou glebas totalmente desocupados, ou onde o coeficiente de aproveitamento mínimo não tenha sido atingido", sendo passíveis de aplicação dos instrumentos acima citados, sucessivamente (art. 13). Dessa forma, também foram definidos os coeficientes mínimo, básico e máximo, a partir dos quais se aplicam diversos instrumentos urbanísticos, além dos citados acima: a) CA básico, que resulta do potencial construtivo gratuito inerente aos lotes e glebas urbanos; b) CA máximo, que não pode ser ultrapassado; e c) CA mínimo, abaixo do qual o imóvel poderá ser considerado subutilizado (PDE, art. 146, inciso IX).

Segundo artigo 201 do PDE, os imóveis considerados passíveis de aplicação desses instrumentos seriam aqueles não edificados, subutilizados e não utilizados, localizados em ZEIS 2 e 3, em áreas de Operações Urbanas Consorciadas, de Projetos Estratégicos e em diversos distritos do município, inclusive aqueles que constituem a área central: Barra Funda, Bela Vista, Belém, Bom Retiro, Brás, Cambuci, Consolação, Liberdade, Mooca, Pari, República, Santa Cecília, Sé. O Plano Regional da Subprefeitura da Sé ampliou o rol de aplicabilidade ao considerar como subutilizados os imóveis não edificados ou com edificações de até 1 pavimento, com área superior a $250 \mathrm{~m} 2$, e utilizados exclusivamente por estacionamentos (PRE Sé, art. 38 e quadro 6B). 
A expectativa sobre tais instrumentos era grande (e ainda é), especialmente no que tange a sua aplicação associada aos mecanismos das ZEIS, que abordaremos na seqüência. No entanto, para sua efetiva aplicação, seria necessária a regulamentação de uma lei específica que determinasse os prazos de notificação e cumprimento das penalidades pelos proprietários, bem como as alíquotas progressivas de IPTU. Nesse sentido, em novembro de 2005, foi encaminhado à Câmara Municipal projeto de lei de autoria do então vereador Paulo Teixeira, mas sua votação ainda não ocorreu, o que tem limitado o cumprimento da função social da propriedade, bem como a aplicação de outros mecanismos instituídos pelo Plano Diretor, como a própria ZEIS.

De todo modo, os instrumentos de indução ao cumprimento da função social integraram o ferramental que garantiriam a produção habitacional em áreas urbanas consolidadas, em conjunto com a implementação dos parâmetros das ZEIS 3 e alguns mecanismos de isenção fiscal e de facilitação na aquisição de imóveis pelo poder público ${ }^{134}$. Os debates que levaram à formulação dos programas de habitação de interesse social, envolvendo diversos setores sociais entre técnicos do poder público, profissionais de assessorias técnicas, pesquisadores e movimentos sociais, pleiteavam a criação desses instrumentos, entendendo-os como fundamentais para viabilidade dos programas.

\begin{abstract}
Desenvolver programas habitacionais em regiões valorizadas ou em processo de valorização não é uma tarefa simples. Para enfrentar essa dificuldade, a prefeitura introduziu no Plano Diretor Estratégico, aprovado em 2002, um conjunto de instrumentos baseados no Estatuto da Cidade. Por outro lado, decidiu criar uma série de incentivos tributários com o objetivo de reduzir o valor incidente dos imóveis utilizados para reforma ou construção nova, assim como taxas municipais diversas incidentes sobre a construção habitacional. (PMSP/SEHAB 2004b, p.69)
\end{abstract}

Os levantamentos de uso e ocupação do solo em grandes áreas dos bairros centrais, realizados no âmbito da montagem de um programa habitacional que estava sendo pensado para áreas urbanas consolidadas (o "Morar Perto"), e que depois viria a se constituir no programa dos PRIH, contribuíram para a definição dos critérios de delimitação das ZEIS 3. Tais levantamentos foram feitos em dois momentos (2002 e 2003) e se desdobraram em indicações de ZEIS 3 tanto no PDE como nos PRE, as quais tiveram ativa participação dos movimentos de moradia do centro e das assessorias técnicas, resultando na delimitação tanto de perímetros como de imóveis vazios isolados e passíveis de reabilitação. Segundo o artigo 181 do PDE (parágrafo $3^{\circ}$ ), os critérios para demarcação de novas ZEIS 3 devem considerar: áreas dotadas de infra-estrutura urbana consolidada, de intensa concentração de cortiços, habitações coletivas e edificações deterioradas;

\footnotetext{
${ }^{134}$ Foram eles a Lei de Dação (LM 13.259/02 e D.M. 42.095/02), criando a possibilidade de negociar o próprio imóvel como forma de facilitar o pagamento dos créditos tributários; a Lei de Remissão da Dívida (LM 13.736/04), permitindo que a prefeitura adquirisse imóveis com dívidas tributarias, para destiná-los à Habitação de Interesse Social mediante reforma ou provisão; e as leis de isenção de ITBI (LM 13.402/02) e ISS (LM 13.476/02), como incentivos a produção de HIS.
} 
e áreas com alto índice de imóveis não edificados, não utilizados ou subutilizados em regiões com infra-estrutura.

As ZEIS, ainda que não definidas pelo Estatuto - há apenas uma menção ao longo da lei, no artigo $4^{\circ}$, sobre os instrumentos do planejamento municipal - foram regulamentadas pelo PDE, tiveram seus parâmetros detalhados num decreto específico (DM 44.667/2004), e depois foram alteradas, em parte, na lei dos Planos Regionais. Como um instrumento urbanístico intrínseco à política habitacional do município, foram criados 4 tipos de ZEIS, sendo a ZEIS 3 definida especificamente para áreas urbanas consolidadas, podendo incidir sobre perímetros ou imóveis isolados. O decreto específico as definiu como:

(...) áreas com predominância de terrenos ou edificações subutilizados, situadas em áreas dotadas de infra-estrutura, serviços urbanos e oferta de empregos, ou que esteja recebendo investimentos dessa natureza, em que haja interesse público na promoção e manutenção de HIS e HMP e na melhoria das condições habitacionais da população moradora, incluindo equipamentos sociais e culturais, espaços públicos, serviço e comércio de caráter local. (DM 44.667/2004, art. 2)

As diretrizes gerais da política habitacional do município enfocavam a produção de Habitação de Interesse Social (HIS) e Habitação de Mercado Popular (HMP) em áreas urbanas consolidadas e dotadas de infra-estrutura, que se encontram subutilizadas, visando à reversão da tendência de periferização do crescimento urbano. Buscava-se melhorar as condições de habitabilidade das famílias de baixa renda, através da intervenção nas habitações coletivas de aluguel (cortiços) ${ }^{135}$ e da recuperação e reciclagem de edifícios subutilizados, produzindo novas unidades e consolidando a moradia social nas áreas centrais (PDE, art. 79 e 80). Para alcançar esses objetivos e diretrizes, foi apontada a necessidade de criar "condições para a participação da iniciativa privada na produção" de HIS e de HMP, "especialmente na área central e nos espaços vazios da Cidade" (PDE, art. 79, inciso X). Como porção do território com prioridade à produção e regularização de HIS, as ZEIS foram norteadas por esses mesmos objetivos e diretrizes, a partir dos quais foram formulados seus mecanismos e parâmetros de aplicação, buscando viabilizar tanto a produção habitacional pública, quanto a privada.

Com a aprovação da nova lei de zoneamento, a mesma que regulamentou os planos regionais, a ZEIS passou a ser considerada como uma zona. Nesse sentido, foram definidos parâmetros e índices urbanísticos próprios (coeficiente de aproveitamento, recuos, etc.), sendo que para a ZEIS 3, o CA mínimo é 0,3; o CA básico é 1,0; e o CA máximo é 4,0 (LM 13.885/2004, art. 140).

135 Os parâmetros de habitabilidade adotados pelo município seguiram os parâmetros estabelecidos na Lei Moura (LM 10.928/91), que defini a adequação das moradias coletivas de aluguel de acordo com algumas regras, como por exemplo, o número de pessoas por equipamento sanitário, a metragem quadrada mínima dos cômodos, etc. Esses parâmetros foram considerados para a implementação do Programa de Cortiços, integrante do Morar no Centro. 
A principal regra da ZEIS é a obrigatoriedade de um percentual mínimo de HIS e HMP para a aprovação de empreendimentos de construção nova ou reforma, com ou sem mudança de uso, e com ou sem aumento de área, que incide nos seguintes tipos de imóveis: (i) lotes e glebas não edificados; (ii) terrenos ocupados por favela; (iii) imóveis utilizados como cortiço; (iv) habitações coletivas precárias; (v) conjuntos habitacionais irregulares ocupados por moradores de baixa renda; (vi) edificações deterioradas; (vii) terrenos com área superior a $500 \mathrm{~m} 2$ e que tenham, no mínimo, $80 \%$ de sua área construída desocupada a mais de cinco anos; e (viii) terrenos com área superior a $250 \mathrm{~m} 2$, nos quais o coeficiente de aproveitamento não tenha atingindo definido para a zona onde se situa (LM 13.885/04, art. 136 e 140).

Para a ZEIS 3, o percentual mínimo obrigatório, definido na lei dos Planos Regionais, é de 40\% para HIS, 40\% para HMP, e 20\% para outros usos (LM 13.885/04, art. 140). Essas porcentagens foram alteradas entre a aprovação do PDE e dos PREs, causando polêmicas entre os grupos que defendiam a habitação social no centro, técnicos e movimentos sociais. Segundo o PDE, o percentual mínimo obrigatório seria de 50\% para HIS e 50\% para outros usos, sendo que a alteração dessa regra parece ter refletido as pressões de setores do mercado imobiliário no sentido de diminuir as limitações dadas pela obrigatoriedade em produzir HIS.

Como forma de incentivar a produção de habitação pela iniciativa privada, os parâmetros das ZEIS 3 permitiam que os empreendimentos enquadrados nessa obrigatoriedade atingissem o CA máximo igual a 4, sem o pagamento da Outorga Onerosa do Direito de Construir (LM 13.885/04, art. 142). Pelo decreto 44.667/04 também foram flexibilizados os parâmetros edilícios para a execução de empreendimentos de HIS, permitindo exceções ao Código de Obras (recuos, gabaritos, exigências de garagens, pés direitos, número de sanitários, etc.) ${ }^{136}$.

A idéia era tornar a ZEIS atrativa, facilitando parcerias com setores do mercado imobiliário e sem "congelar" as áreas, com a expectativa de que a permissão do uso de um CA=4 fosse vantajoso, se comparado aos CAs das outras zonas de uso. No entanto, como podemos notar no mapa 7, algumas zonas delimitadas na área central também passaram a permitir altos CA (em sua maioria $\mathrm{CA}=2,5)$, apesar de não possibilitar isenções de outorga, com exceção de casos específicos. A manutenção da Operação Urbana Centro, que permite chegar num CA igual a 12 para determinados usos, e a criação de novas operações para os distritos centrais, em que se poderia

\footnotetext{
136 Esse mesmo decreto definiu HIS como aquela de promoção pública ou conveniada, destinada às famílias com renda até 6 salários mínimos e com preço de comercialização compatível com a demanda, que segue resolução da CAEHIS - Comissão de Análise de Empreendimentos Habitacionais de Interesse Social, baseando-se nos parâmetros colocados pela Caixa Econômica Federal. Também foi definida HMP como aquela destinada a famílias com renda até 16 salários mínimos e de promoção privada. Foram definidos as áreas úteis máximas de cada tipo de unidade habitacional (50m² para HIS e 70 m² para HMP), os números de vagas de garagens e sanitários, e pés direitos.
} 
alcançar CAs igualmente altos, também tendem a limitar essa atratividade da ZEIS. Importante destacar que em casos de sobreposição de ZEIS 3 e Operação Urbana, prevalece os parâmetros de intensidade de ocupação do solo (CA) definido na lei específica dessa última, com a isenção do pagamento da Outorga Onerosa mantida apenas para a construção de HIS e HMP.

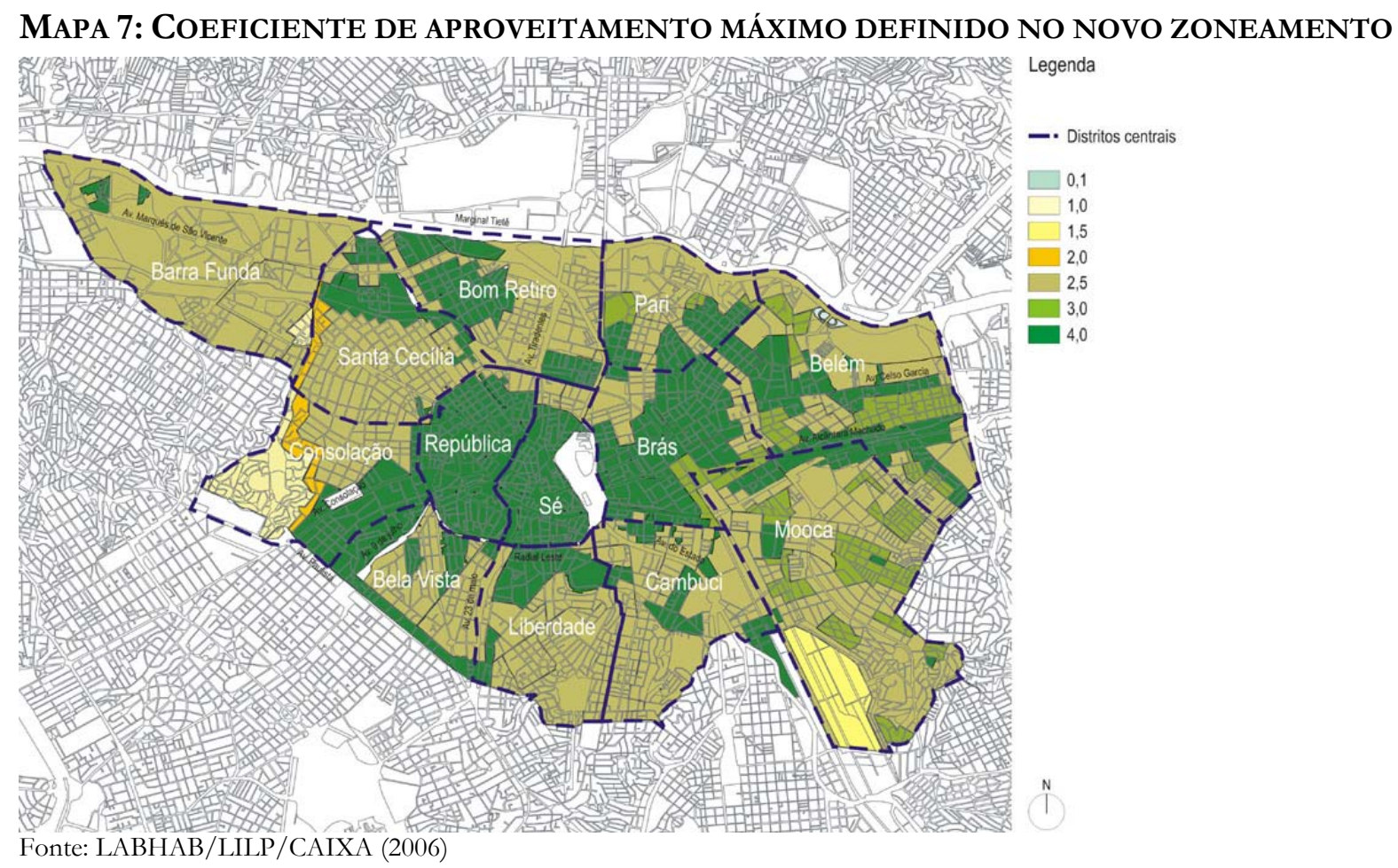

Além da indução ao cumprimento da função social da propriedade e da isenção da Outorga Onerosa, seriam aplicáveis nas ZEIS 3 os seguintes instrumentos urbanísticos: Transferência do Direito de Construir; Usucapião, Direito de Superfície e Direito de Preempção.

Muitas das áreas de ZEIS 3 coincidiam com as áreas dos PRIH, e seus escritórios locais atuantes nesses últimos - Escritório Antena (EA), equipes multidisciplinares que deveriam funcionar como braços do poder público no território - tiveram importante papel no esclarecimento das regras das ZEIS aos proprietários de imóveis. Esses escritórios também propunham "estratégias de aproveitamento e financiamento para viabilizar empreendimentos privados ou em parceria" (PMSP/SEHAB, 2004b: 70). Cabe lembrar que a concepção do programa dos PRIH tomou como referência algumas experiências internacionais de reabilitação de bairros centrais históricos, que tiveram enfoque na recuperação de edifícios existentes para moradia social de aluguel e na preservação do patrimônio histórico comum/não monumental, implementando instrumentos urbanísticos que garantissem a realização das intervenções e a manutenção dos moradores 
originais de baixa renda, como os casos portugueses e franceses abordados anteriormente. Essa referência foi especialmente fundamental para a montagem dos programas de Locação Social e dos PRIHs, o que foi reforçado pelo estabelecimento de uma cooperação técnica com a França.

No entanto, como já apontou Villaça (2005, p.43), a maioria dos instrumentos instituídos pelo Estatuto da Cidade e regulamentados pelo Plano Diretor depende da "adesão do setor imobiliário" para serem implementados, como é o caso das Operações Urbanas abordadas anteriormente e da própria ZEIS 3. Se considerarmos que, nas últimas três décadas, o interesse de investidores privados - e do Estado - tem se deslocado na direção do quadrante sudoeste, alcançando as regiões da Marginal Pinheiros e Avenida Nações Unidas - como apontado no capítulo 2 - indagamos se a aplicação desses instrumentos urbanísticos, mesmo que associados aos projetos tipo “alavanca” propostos pelo Ação Centro, serão suficientes para atrair novos investimentos para a área central.

Com a inserção dos programas de habitação social no escopo do financiamento do BID, a concepção e discussão sobre os instrumentos urbanísticos citados acima acabaram permeando a montagem do Programa Ação Centro. Essa inserção, a nosso ver, concedeu à ZEIS 3 um papel fundamental para a reabilitação da área central, reforçando os objetivos de repovoamento e sendo um dos únicos mecanismos que poderiam minimizar os efeitos "negativos" da valorização imobiliária decorrente das ações de atração de investimentos privados, os quais objetivavam mudanças nos padrões de uso e ocupação do solo, evitando assim, a expulsão da população de baixa renda da área.

A despeito do caráter inédito das ZEIS 3, decorrente da proposição de mecanismos que permitem ao poder público exercer controle sobre a produção do espaço urbano, principalmente através da indução ao cumprimento da função social da propriedade, pesquisas recentes mostraram que seus ainda são muito tímidos (TSUKUMO, 2007). Foi realizado apenas um empreendimento até o momento, localizado na PRIH Luz, com obras em fase de finalização. 


\section{Conclusão. Ambigüidades do Programa AÇão Centro}

Nesta dissertação procuramos investigar as recentes práticas urbanísticas da Prefeitura de São Paulo para a área central da cidade, com foco naquelas formuladas durante a gestão da Prefeita Marta Suplicy (2001-2004) a partir do financiamento externo de um organismo multilateral - o Banco Interamericano de Desenvolvimento. As tratativas com esse banco, iniciadas em meados da década de 1990 e prolongadas por um período de 4 gestões municipais até o momento, conduziram a Prefeitura na elaboração de um programa de ações (obras, serviços, formas de gestão) condizente com os princípios do banco.

As diversas propostas elaboradas ao longo deste período apresentaram diferentes visões sobre a recuperação de centros urbanos, na maior parte do tempo adotando um léxico de cunho neoliberal e seguindo os modelos da gestão urbana empresarial - defendidos pelo BID - mas em alguns momentos conseguindo incorporar - sem muito efeito - princípios urbanísticos que correspondem às demandas locais de grupos de baixa renda, buscando contrapor-se aos processos de "gentrificação". Como vimos, tais visões representam interesses distintos e configuram disputas pela produção e apropriação do espaço urbano, num embate de projetos e modelos de intervenção díspares.

A concepção do programa Ação Centro ocorreu em meio a essas disputas e envolveu as diferentes abordagens sobre a recuperação da área central, ao mesmo tempo em que foi promovido por um governo declaradamente voltado para a defesa dos interesses populares, porém em meio a um contexto de governabilidade fortemente neoliberal. Isto significou a adoção de estratégias e objetivos contraditórios sob um mesmo discurso argumentativo em prol do desenvolvimento econômico e social da área, com diversidade e "inclusão social". 
A decisão pela continuidade das negociações com o BID, durante a gestão Marta, foi justificada pelas limitações orçamentárias - uma explicação que se tornou comum nos anos 90 em muitas prefeituras devido aos limites impostos pela Lei da Responsabilidade Fiscal - e pela prioridade dada à reabilitação da área central. Essa última, motivada antagonicamente, por um lado, pelos movimentos populares do centro pertencentes à base de apoio eleitoral daquela gestão, e por outro, pelos modelos urbanísticos em voga, sobre os quais falamos ao longo deste trabalho.

O contexto de crise fiscal e as restrições ao endividamento do município, decorrentes da aplicação automática da lógica da responsabilidade fiscal e da priorização da contenção do déficit público em relação aos gastos públicos sociais, transformaram o empréstimo do BID numa das únicas fontes de recurso para suas ações no centro. Isso parece ter colocado a Prefeitura numa condição de subordinação às exigências do banco, determinando muitas de suas decisões e prioridades. Desse modo, o ponto de partida para a montagem do programa de reabilitação da área central do governo petista foi, em certa medida, o conjunto de determinações do BID.

Vimos no capítulo 3 que os modelos de intervenção e gestão pública adotados pelos bancos multilaterais, associados aos ajustes econômicos neoliberais, introduzidos pelo Consenso de Washington para os países periféricos, estiveram claramente presentes no escopo do Programa Ação Centro. A partir da difusão de "best practices", os bancos têm atuado deliberadamente no âmbito das sugestões práticas de políticas urbanas, e assim têm pregado um receituário considerado bem sucedido de redução de gastos públicos e flexibilização da legislação urbanística e da gestão, numa lógica econômico-financeira de determinação dos projetos financiados.

Sendo uma exigência do BID, inclusive para a liberação do primeiro desembolso do financiamento, a montagem da Agência de Desenvolvimento do Centro no âmbito do programa alinhou-se à propagada idéia de "retirada" do Estado e de diminuição de seu controle sobre o processo de produção do espaço urbano. Ainda que não implementada de forma efetiva, essa Agência tinha como pressuposto transformar o poder público em agente facilitador e fomentador de atividades econômicas no centro - em "uma nova mentalidade de gestor público" - captando recursos e atraindo investimentos privados num contexto de crise e "competição entre cidades", com vistas a dinamizar a economia local.

Seguindo exemplos de experiências estrangeiras de gestão urbana empresarial - Barcelona, Buenos Aires, entre outros - a idéia consistia em criar um espaço de articulação com setores do capital para a realização de projetos no centro, visando alcançar seu desenvolvimento econômico. Num país onde nunca houve uma tradição de controle do Estado sobre o urbano, ou mais especificamente sobre a livre-iniciativa dos setores economicamente dominantes na produção do 
espaço urbano, a formação desta Agência só poderia servir para reforçar o histórico favorecimento a interesses privados e manter privilégios, levando a uma recuperação da área central que acentuaria a segregação sócio-espacial do processo de produção da cidade, contradizendo a preocupação quanto à “inclusão social” explicitada no programa.

Essa estratégia tenderia a ser potencializada pela focalização dos investimentos do programa intervenções urbanísticas e outras melhorias do ambiente urbano, realizadas com aporte de recursos públicos - num território onde pudessem causar um "efeito de sinergia" e a otimização de seus impactos, ou seja, gerar o interesse de investidores privados pela área. Tal procedimento subverte completamente a idéia de público como campo de ação do Estado, ou seja, de organização e controle do território e do ambiente construído de acordo com a demanda social coletiva, já que subordina o planejamento urbano e as políticas públicas aos interesses e potencial de alavancagem do capital privado. É a partir desse interesse, e não mais de prioridades sociais estabelecidas pelo Estado, que se desdobraria o desenvolvimento urbano "sinérgico" pretendido.

Nesse sentido, vimos nos capítulos 1 e 3 que a decisão por concentrar as ações do programa nos distritos Sé e República - Área de Interesse - foi decorrência de uma exigência do banco financiador, obviamente seguindo o princípio dos modelos em voga de que a reabilitação do centro seria alcançada apenas por meio da atração de investimentos privados.

Os levantamentos realizados pela Prefeitura com setores da sociedade, identificando essa Área de Interesse como o centro da cidade, justificaram a escolha pela focalização, a despeito da eminente expulsão da população de baixa renda e dos usos populares, decorrente de uma almejada valorização imobiliária. Essa última tem sido resultado comum nas experiências de recuperação de centros, realizadas em países centrais do capitalismo, sendo que, caso as estratégias da recuperação do centro de São Paulo dêem certo, ela será inevitável aqui também.

Além disso, o princípio da focalização está diretamente relacionado com a lógica econômicofinanceira que determina os projetos financiados pelo BID. A Área de Interesse do programa consistiu na sua área "elegível”, onde haveria potencial de atração de investimentos privados e consumidores que garantiriam o retorno econômico dos investimentos públicos realizados - a "recuperação dos custos do projeto". Tal lógica pode ser percebida na utilização de um modelo econométrico para analisar os impactos (econômicos) do programa na área central, verificando sua viabilidade econômica. A partir de 4 cenários de investimento possíveis - cultura, negócios, habitação e integrado - procurou-se averiguar o retorno financeiro das ações propostas, adotando uma estratégia de intervenção que maximizasse seus benefícios econômicos. 
O sistema de monitoramento e avaliação do programa - outra exigência do BID, padrão em seus contratos de financiamento - também explicitou essa lógica. Como vimos, destacaram-se os indicadores de avaliação do impacto das ações, procurando medir o aumento dos valores de imóveis residenciais e não residenciais, da especialização econômica terciária da área central, dos valores lançados de ISS/ITBI/ICMS, do aumento do mercado efetivo de trabalho, entre outros, visando um aumento da arrecadação pública. Se por um lado foram criados indicadores de monitoramento da população vulnerável - aquela passível de ser expulsa da área por decorrência dos "efeitos negativos" do próprio processo de reabilitação - por outro, pode-se dizer que tal sistema teve como objetivo avaliar os impactos do programa através de "indicadores de sucesso" voltados a averiguar a redinamização econômica e a valorização imobiliária da área central.

Adequando-se aos modelos do BID, fica claro que o objetivo último das estratégias do programa foi o de alcançar a retomada econômica da área central - especificamente da Área de Interesse atraindo usos mais rentáveis, consumidores de maior poder aquisitivo, valorizando imóveis e aumentando a arrecadação tributária da Prefeitura. Um modelo de desenvolvimento em que é imprescindível a transformação do perfil de uso e ocupação da área e, portanto, a atração de investimentos privados. A transferência de órgãos do poder público para o centro também se enquadrou nessa estratégia, uma vez que os funcionários públicos representam uma demanda potencial para o desenvolvimento de novos comércios e serviços.

Como parte dessa estratégia de retomada econômica seria necessário tornar a área central atraente para os investidores, o que seria possível, como vimos no capítulo 1, através da realização de uma série de intervenções urbanísticas e ações de melhoria do ambiente urbano, que representavam a maior parte do montante de recursos previstos para o programa. Entre elas, as reformas de praças, a melhoria de calçadas, o ordenamento de equipamentos e do mobiliário urbano, a recuperação do patrimônio histórico edificado, a diminuição das linhas de ônibus que acessam o centro, a inibição e retirada do comércio ambulante das ruas e calçadões e, no limite, a retirada dos moradores de rua, atendendo-os na rede de proteção social.

A determinação do elenco de ações do programa por essa estratégia explicitou-se nos "projetos motores", emblemáticos do propósito de induzir ou "alavancar" os investimentos privados empreendimentos imobiliários, instalação de empresas - a partir do aporte de recursos públicos. Destacavam-se as propostas de reurbanização do Parque Dom Pedro II e imediações, com a criação do chamado "Museu da Cidade" no Palácio das Indústrias, em associação com a implantação da Operação Urbana Diagonal Sul. Vimos que o propósito era construir um “ambiente favorável aos negócios" que garantisse os objetivos do programa de recuperação da 
área central, gerando um efeito de melhoria no entorno das intervenções realizadas. Alguns dos componentes de atenção aos grupos vulneráveis e de regulação do comércio ambulante, apesar de explicitarem uma preocupação em minimizar os "efeitos negativos" da própria reabilitação da área, iriam contribuir para esse ambiente favorável. Em associação com a questão da segurança pública, pretendia-se retirar a população de rua, atendendo-a na rede de proteção social, e propunha-se uma atuação conjunta com a Guarda Civil Metropolitana para inibição da atividade informal.

Tal propósito é a essência do planejamento estratégico, como vimos no capítulo 3, cujo receituário tem sido amplamente difundido pelos organismos multilaterais e consultores internacionais, através da divulgação de experiências exitosas (as "best practices") - Barcelona tem sido seu caso mais paradigmático, inclusive citado em documento oficiais do Programa Ação Centro. No contexto da chamada reestruturação produtiva e de crise dos princípios modernos do planejamento urbano, as técnicas desse "novo" planejamento associou-se aos discursos e teorizações sobre as "cidades-globais", segundo os quais faz-se vital dotar as cidades de certos atributos que as insiram na rede de competição global pela atração de capital privado preferencialmente internacional.

Percebe-se, nesse sentido, que a abordagem dada pelo Programa Ação Centro adotou os modelos urbanísticos das recentes experiências de planejamento estratégico e gestão urbana empresarial, analisados no capítulo 3, o que nos leva a afirmar que houve um claro alinhamento à corrente dominante do pensamento urbano contemporâneo, de cunho abertamente liberal. Dessa forma, tal abordagem afastou-se enormemente das experiências realizadas em Portugal, na França e na Itália, focadas na reabilitação urbana - a despeito dessas últimas terem sido referência para a montagem do componente habitacional que foi inserido no escopo do programa.

Ao mesmo tempo, vimos no capítulo 2 que as propostas para recuperação do centro de São Paulo, lançadas desde o início da década de 1990 - como a Operação Urbana Anhangabaú durante a gestão Luiza Erundina - também se alinharam aos princípios do planejamento estratégico. Apesar de algumas iniciativas que procuraram atender reivindicações de movimentos sociais e garantir uma ocupação da área de forma democrática, as propostas formuladas nesse período - inspiradas nas experiências estrangeiras de planejamento estratégico - levaram à construção de um modelo dominante de intervenção urbana, a partir do qual a recuperação da área central deveria ocorrer mediante sua retomada econômica e a valorização imobiliária. Para essa construção foi fundamental a atuação de grupos e setores do capital, em especial da Associação Viva o Centro (AVC), chamando atenção para o quadro de "degradação" do centro e 
defendendo a requalificação do mesmo para que se evitasse a saída de empresas "modernas" que passaram a preferir as "novas centralidades" a sudoeste da cidade. Essa requalificação do centro deveria envolver a recuperação de seu papel simbólico para a cidade.

A AVC ganhou espaço de interlocução com os governos estadual e municipal, pautando programas e políticas para a área. Além dos projetos de incentivo ao uso cultural na região da Luz, coordenados pelo Governo do Estado, a AVC pleiteou a criação do PROCENTRO programa que pautou as primeiras negociações para o empréstimo do BID - da Operação Urbana Centro e da Lei de Fachadas - instrumentos urbanísticos vigentes, que foram regulamentados em 1997, durante a gestão de Celso Pitta (1997-2000). Ainda que esses instrumentos não tenham obtido resultados satisfatórios naquilo que se propunham desencadear a requalificação do centro através da flexibilização da legislação urbanística existente e do estímulo à preservação do patrimônio histórico edificado - vimos que serviram à construção do modelo citado acima, de cunho neoliberal e pautado nas parcerias do poder público com setores do capital privado.

Conduzindo as justificativas para esse entendimento dominante da recuperação do centro, propalou-se a idéia de que transformações urbanas em curso estariam resultando num quadro de "degradação" do mesmo, associado diretamente à sua popularização e ao seu esvaziamento. Segundo tal idéia, presente em diagnósticos e estudos elaborados desde a década de 1970, o centro teria se esvaziado, desvalorizado e perdido sua identidade, em decorrência de sua ocupação por usos populares, comércio informal e classes de baixa renda, da "feiúra" e não conservação de espaços públicos e edifícios, da inadequação de seu estoque imobiliário frente às demandas econômicas contemporâneas ("globais") e, mais recentemente, das dificuldades em acessá-lo por automóvel. Diante desse quadro, seria necessário estimular a volta ou instalação de novos comércios e serviços sofisticados, classes de maior poder aquisitivo, setores do mercado imobiliário, entre outros usos e atividades de alto padrão, que estariam saindo do centro devido sua "degradação" e "obsolescência". Seria preciso "retomar" o centro.

No entanto, pudemos perceber que transformações do centro têm ocorrido desde o início do século XX, mediadas pelo processo de produção do espaço da metrópole paulistana, vinculadas à abertura dos primeiros bairros exclusivos de alta renda, cujo "caminhamento" arrastou para perto de si as atividades econômicas centrais, como nos mostrou Villaça (2001), deslocando o próprio centro - o das elites. A lógica do "novidadesco" operada pelo mercado imobiliário privado e a ação do Estado favorecendo essa operação - investindo em infra-estrutura, melhorando as condições de deslocamento dos novos bairros exclusivos - ambas voltadas aos interesses das 
camadas de alta renda, produziram a obsolescência de antigas áreas, que passavam a ser ocupadas por usos menos sofisticados e populares, como é o caso do centro propriamente e de alguns bairros centrais. Um processo de transformação do espaço urbano central que não se configura como algo recente, apesar suas especificidades contemporâneas. Processo este também marcado por movimentos de permanência e mudança, em que ocorria, ao mesmo tempo, a dispersão das atividades econômicas voltadas às elites e à intensificação dos usos no centro, uma perda dos usos residenciais e a construção de grandes edifícios verticais de uso misto.

Produziu-se uma idéia de centro - sua imagem - como espaço exclusivo das camadas dominantes de alta renda, homogêneo, que serviu para representação de seu domínio político e econômico, mascarando as disputas pelo espaço. O controle dessas camadas sobre o espaço central adaptouo aos seus interesses e demandas, especialmente através da ação do Estado, realizando as intervenções de higiene e saneamento, os projetos de embelezamento, as obras viárias, regulamentando as legislações de uso e ocupação do solo, expulsando classes sociais e usos indesejados. Mas ao longo do século XX, como vimos, a área central tornou-se o espaço mais disputado pelos diversos grupos sociais, o "ponto" da cidade que mais otimiza os deslocamentos dentro da aglomeração urbana. Ao invés de homogêneo, como a idéia de espaço exclusivo quer fazer entender, porções da área central foram ocupadas por camadas populares durante todo seu processo de produção/transformação, o que também foi possível por sua própria valorização fundiária. Tal presença popular, em conjunto com os deslocamentos dos bairros de alta renda, gerou diferenciações internas à área central que, portanto, não é e nunca foi homogênea.

Nesse sentido, nos parece que a retomada e recuperação de sua identidade, defendidas nos projetos de revitalização, requalificação ou reabilitação do centro, seriam necessárias para manter seu papel simbólico, já que as camadas de alta renda não poderiam abandonar totalmente aquilo que é o espaço de representação de seu domínio econômico e político. Mascaram-se, mais uma vez, as disputas pelo espaço central, construindo um discurso ideológico do que seria intervir nesta porção da cidade.

Em certa medida, o Programa Ação Centro pode ser analisado à luz destas idéias dominantes de "degradação" e "retomada", pois seu processo de concepção e implementação foi mediado por um entendimento similar das transformações do centro, ainda que os gestores públicos envolvidos tenham tomado o cuidado para uma diferenciação entre sua deterioração física e sua popularização. A própria delimitação da área foco do programa, ratificando aquilo que comumente se entende por centro (distritos Sé e República), contribuiu com estas idéias dominantes, adequando-se aos objetivos de "alavancagem” da recuperação econômica da área. 
Neste sentido, complementando a estratégia de retomada da área central através do fomento às atividades econômicas, aos novos investimentos imobiliários privados e usuários de maior poder aquisitivo - alinhando-se aos princípios do modelo de intervenção que se tornou dominante em São Paulo ao longo da década de 1990 - o Ação Centro contou com a manutenção e proposição de novos mecanismos de atração e estímulo aos investidores. A Prefeitura manteve a Operação Urbana Centro, regulamentou a Lei de Incentivos Seletivos e propôs a Operação Urbana Diagonal Sul - que estava em estudo e tinha sido instituída pelo Plano Diretor - atendendo a pressões de grupos como a própria Associação Viva o Centro. Tais mecanismos reforçariam a atratividade da área, em conjunto com as intervenções urbanísticas e os projetos motores destinados a construir o "ambiente favorável aos negócios", buscando reinseri-la no circuito do mercado imobiliário. Como vimos, havia também uma expectativa quanto à regulamentação dos Planos Regionais incidentes na área central (Sé e Mooca), entendidos como "marco regulador estável para os investidores". Diversos projetos do Ação Centro foram inseridos em seus textos legais, associando-se aos mecanismos e instrumentos urbanísticos aprovados, no entanto, sabe-se que os planos diretores possuem um histórico de não implementação.

Apesar de sua vinculação ao pensamento dominante da recuperação de centros urbanos, um dos objetivos do programa era realizar um processo de reabilitação com diversidade e "inclusão social". Como vimos no capítulo 1, essa intenção seria garantida pelos componentes de atenção aos grupos vulneráveis, geração de emprego e renda e habitação de interesse social, que deveriam minimizar os possíveis "efeitos negativos" das ações do próprio programa, decorrentes de seu propósito de criar as condições para tornar o centro atraente à instalação de novas atividades, gerando sua retomada econômica e valorização imobiliária. Portanto, no modelo proposto pelo banco - e adotado pela Prefeitura, até certo ponto - aceitava-se a "gentrificação" no processo de recuperação do centro da cidade.

Através das propostas do campo habitacional, por exemplo, cuja formulação ocorreu inicialmente em paralelo às negociações com o BID para a tomada do empréstimo, procurava-se evitar a expulsão da população de baixa renda da área central, considerando a necessidade de criar mecanismos de controle dos valores fundiários e de indução à produção pública e privada de habitação social. Tais propostas, ainda que não implementados em sua totalidade e polêmicas quanto à efetividade da indução da produção privada - em certa medida, dependente dos interesses de proprietários e incorporadores - retomaram as discussões realizadas durante a gestão Luiza Erundina (1989-1992) e representaram uma tentativa de efetivar a política habitacional na área central da cidade. 
Tiveram também como referência experiências estrangeiras focadas na reabilitação urbana, em especial aquelas realizadas na França e em Portugal, que priorizavam a reconstituição morfológica das áreas de intervenção, com respeito às tipologias edificadas, às dinâmicas econômicas existentes, assim como dando atenção maior às demandas sociais e ao direito à moradia das populações residentes. Como vimos no capítulo 3, nessas experiências associava-se a política de preservação do patrimônio histórico com a estruturação da política habitacional, com o claro objetivo de garantir a fixação dos moradores originais das áreas de intervenção, geralmente de baixa renda. Ainda que no caso paulistano o enfoque no patrimônio histórico tenha sido bem menor, vimos que o principal objetivo dos programas habitacionais propostos também era manter a população de baixa renda na área.

Nesse sentido, seus objetivos eram antagônicos ao propósito último da reabilitação através da atração de investimentos privados e da valorização imobiliária, alinhado aos princípios da gestão urbana empresarial defendidos pelo banco financiador. Não foi por acaso que houve embates entre o banco e a Prefeitura neste tópico, assim como embates internos ao corpo administrativo municipal, já que a produção de habitação social atenderia uma demanda de baixo poder aquisitivo e, portanto, não estimuladora dos novos estabelecimentos comerciais e de serviços que se pretendia atrair.

A definição da área de abrangência de cada componente do programa também demonstrou esse embate, explicitando os diferentes pressupostos que os condicionou. A maior parte das intervenções que buscavam a melhoria do ambiente urbano - a construção do "ambiente favorável aos negócios" - recaiu sobre a Área de Interesse e algumas porções adjacentes ao Parque Dom Pedro II. Era a área "elegível” do financiamento do BID que recebia as ações de requalificação de espaços e edifícios públicos, restrições ao comércio informal, aumento da segurança, melhoria da micro-acessibilidade por automóveis, entre outros. Enquanto que os programas de habitação e de assistência social tiveram suas ações implantadas fora dessa área foco: Favela do Gato; Projeto.Oficina.Boracea.; PRIH, entre outros.

Ao englobar o componente habitacional em seu escopo, o Programa Ação Centro também adotou um discurso de defesa pela moradia popular na área central, reforçando-o como uma das bandeiras da gestão Marta. No entanto, essa inserção fez com que o componente assumisse um caráter mais reativo frente à eminente expulsão da população de baixa renda, moradora de cortiços e habitações precárias, do que se tornasse uma prioridade dentro das propostas para a recuperação da área central. O que ocorreu foi uma junção de estratégias e objetivos antagônicos num mesmo programa, num mesmo escopo de financiamento externo, exigindo a formulação de 
um discurso que servisse a todos esses objetivos: "promover o desenvolvimento social e econômico com diversidade da Área Central de São Paulo, dinamizando e criando condições de atração e suporte de atividades compatíveis com o centro metropolitano e promovendo a reabilitação urbanística e ambiental da área, com inclusão social”.

Se considerarmos que era aceito certo grau de "gentrificação", como apontado, a idéia de diversidade ou pluralidade sócio-econômica, ainda que respaldando as iniciativas de caráter democrático, serviu para a construção de um discurso ideológico da recuperação da área central, que mascarou os objetivos de transformar o perfil de usos e atividades e retomar sua dinâmica econômica. A partir dessa idéia, defendeu-se tanto a atração de investimentos privados e moradores de renda média, como a permanência da população de baixa renda e das atividades econômicas voltadas a ela; a primeira estratégia, como alertado nos próprios documentos oficiais do programa, poderia dificultar ou mesmo impedir - gerar "efeitos negativos" - a efetivação da segunda.

Originada nos movimentos de contracultura dos anos 60 e 70, nos países centrais do capitalismo, como contraponto aos paradigmas modernos do planejamento urbano, a idéia de diversidade social embasou as iniciativas da chamada nova esquerda, procurando atentar para as especificidades locais e envolver a população nos processos de elaboração e implementação de projetos. Entre essas iniciativas estão as de Conservação Integrada e Reabilitação Urbana que tratamos no capítulo 3 e que foram referências para a montagem dos programas de moradia social.

No entanto, como vimos, os discursos em prol da diversidade social tem sido freqüentemente utilizado nos projetos de revitalização de centros e bairros centrais mundo afora, capturados por outros grupos e utilizados em práticas urbanísticas de caráter neoliberal - uma troca de mãos de "bandeiras". Desta forma, tais discursos têm funcionado como "cortina de fumaça" para objetivos de substituição do perfil sócio-econômico dos usos e da população local "gentrificação" - assim como mascarou os objetivos apresentados pelo Programa Ação Centro: a atração de usos mais rentáveis e camadas de maior poder aquisitivo, em conjunto com a reversão da "desvalorização afetiva" do centro - recuperação seu papel simbólico - contribuindo para uma "mudança de sua imagem", que possibilitaria atração de mais investimentos privados, numa reação em cadeia, revertendo sua "degradação".

Ao abarcar diferentes princípios da recuperação da área central e procurar conferir um caráter democrático e de "inclusão social” às suas propostas, fazendo caber propósitos contrários numa mesma estrutura programática, o Ação Centro dotou-se de um discurso ambíguo. De um lado, 
rendeu-se aos modelos dominantes de cunho neoliberal - em parte determinados pelo BID e em parte difundidos por grupos locais e aceitos pelos gestores públicos - que pressupõem a necessidade de aportes de recursos públicos para atração de investimentos privados na recuperação e revalorização de áreas urbanas consideradas degradadas; de outro, procurou inserir programas de inclusão social e produção de moradia popular que garantissem a fixação da população de baixa renda moradora e usuária da área, almejando um processo democrático de reabilitação urbana e se contrapondo ao histórico processo de segregação sócio-espacial.

Essas diferentes abordagens representam a disputa sobre a produção e apropriação do espaço urbano central, ao mesmo tempo em que retratam a ambigüidade enfrentada, não só no Brasil, por governos de esquerda frente ao desafio da gestão pública em um contexto de pensamento liberal dominante e de economia financeirizada. No entanto, essas abordagens não são de fácil identificação, na medida em que seus discursos são permeados por elementos de confusão ideológica - o que é comum no atual contexto pós-moderno e neoliberal - fazendo caber numa mesma justificativa ou explicação teórica, práticas divergentes e conflitantes. Desta forma, partindo do pressuposto de que seria preciso flexibilizar a gestão pública, realizando ações em parcerias com setores da iniciativa privada - idéia dominante e exigência do BID - construiu-se um discurso ambíguo no âmbito do Programa Ação Centro que abarcou modelos de desenvolvimento urbano díspares. Defendeu-se, ao mesmo tempo, uma atuação pública fomentadora da livre-iniciativa e um maior controle público sobre a produção do espaço urbano - com predomínio da primeira.

Tal ambigüidade parece ser propícia para a atual gestão municipal, uma vez que a alteração ou exclusão de muitas das ações propostas, em especial aquelas que procuravam fixar a população de baixa renda na área - programas de habitação social, principalmente - em nada alteraram a finalidade e o propósito do programa: "promover o desenvolvimento econômico e social da área central de São Paulo, com diversidade" e "manter, criar e tornar mais atraente as condições para o exercício das atividades privadas nesta área” (EMURB/FIPE, 2006, p.87).

Com a mudança de governo, a lógica da retomada econômica da área central foi exacerbada, adotando definitivamente os preceitos da gestão urbana empresarial e do planejamento estratégico. A partir de 2005, os componentes e ações do programa foram concentrados numa área do bairro da Luz conhecida como "Cracolândia", a fim de alcançar os objetivos de renovação do Projeto Nova Luz, voltados à constituição de um pólo tecnológico. Alinhando-se aos planos de intervenção do governo do Estado para a região (Projeto Pólo Luz) e aos esforços do Programa Monumenta-BID, a atual gestão municipal realizou, portanto, um conjunto de 
mudanças relativas à área de abrangência, às estratégias e prioridades do programa de reabilitação da área central.

Por exemplo, a Lei de Incentivos Seletivos, cuja incidência recaía sobre a Área de Interesse do Programa Ação Centro (distritos Sé e República), passou a enfocar a área do novo projeto e definir usos específicos a serem incentivados - empresas de informática e tecnologia, escritórios de propaganda e marketing, shopping centers, galerias de arte, entre outros. Claramente uma intenção de substituir os usos e atividades existentes, por outros, mais rentáveis, modernos e sofisticados. Ao mesmo tempo, o componente habitacional foi praticamente eliminado, restringindo-se a poucos empreendimentos (400 unidades habitacionais) previstos pela CDHU (Governo do Estado) na mesma área do projeto Nova Luz. Isso sem mencionar as ações fortemente repressivas contra comércio informal em diversas porções da área central, em confrontos abertos entre Guarda Civil Metropolitana e ambulantes; o considerável número de despejos de famílias que moram em edifícios ocupados por movimentos de moradia; e as "Operações Limpa" que, entre outras ações, removeu de forma agressiva moradores de rua do espaço público.

Num cenário em que disputas são travadas na e pela área central, não apenas em confrontos abertos, mas também representadas em embates entre diferentes entendimentos de centro e projetos para o mesmo, significando interesses díspares sobre o espaço urbano, tem sido dominante a atuação de grupos que explicitam seu alinhamento a práticas de cunho neoliberal. Promove-se uma inversão da idéia de público por meio de estratégias que procuram fomentar a livre-iniciativa de setores do capital na produção do espaço urbano, o que no âmbito de programas de reabilitação da área central da cidade significa, necessariamente, a expulsão de populações pobres e atividades modestas, eliminando os tecidos sociais e urbanos pré-existentes e ratificando a lógica de segregação sócio-espacial da metrópole paulistana.

Resta o desafio, diante de um contexto de "pensamento único", de efetivar um modelo de desenvolvimento urbano que possibilite reverter os históricos processos segregação e enfrentar as relações de dominação expressas no espaço. 


\section{REFERÊNCIAS BIBLIOGRÁFICAS}

ABRAHÃO, Sérgio Luis. Cooperação entre o Poder Público e a Iniciativa Privada: uma relação delicada. Dissertação de Mestrado apresentada à Faculdade de Arquitetura e Urbanismo da Universidade de São Paulo. São Paulo: FAUUSP, 1999.

ALMEIDA, Marco Antonio Ramos de. "Requalificação do Centro: um projeto que permeia gestões”. In Viva o Centro, Associação. Revista URBS. Ano V. n. 35. Disponível em: http://www.vivaocentro.org.br/publicacoes/urbs/urbs35.htm\#panorama. Acessado em novembro de 2006. São Paulo: agosto/setembro, 2004.

ARANTES, Olítia Beatriz Fiori. “Uma Estratégia Fatal: a cultura nas novas gerações urbanas”. In ARANTES, O.; VAINER, C.; MARICATO, E. Cidade do Pensamento Único: desmanchando consensos. Petrópolis: Vozes, 2000, p. 11-74.

ARANTES, Pedro. O Ajuste Urbano: as políticas do Banco Mundial e do BID para as cidades latino-americanas. Dissertação de Mestrado apresentada à Faculdade de Arquitetura e Urbanismo da Universidade de São Paulo. São Paulo: FAUUSP, 2004.

BANCO INTERAMERICANO DE DESENVOLVIMENTO. "Programa de Rehabilitación del Área Central del Municipio de São Paulo - Procentro (Br-0391). Informe de Proyecto”. Washington: BID, outubro de 2004. In PMSP/EMURB. Ação Centro - Programa de Reabilitação da Área Central de São Paulo. Mídia digital (CD). São Paulo: EMURB, 2004 (a).

Rehabilitación del Centro Histórico de Quito (EC-0169). Propuesta de Préstamo. Disponível em http://www.iadb.org/projects. Washington: BID, setembro de 2004 (b).

Programa de Rehabilitación del Área Central del Municipio de São Paulo - Procentro (Br-0391). Propuesta de Préstamo. Disponível em http://www.iadb.org/project. Washington: BID, outubro de 2003.

BARRETO, Jules. "Uma ONG para o Centro”. In VIVA O CENTRO. Revista URBS n.2. São Paulo: 1997.

BERNARDES, Cláudio. "Reforma e reciclagem de edificações na área central e legislação pertinente". In Mesa de debates. Comissão de Estudos sobre Habitação na Área Central. São Paulo: Câmara, set. 2001.

BIDOU-ZACHARIASEN, Catherine (coord). De Volta à Cidade: dos processos de gentrificação às politicas de 'revitalização' dos centros urbanos. Tradução SILVA, Helena M. Barreto. São Paulo: Annablume, 2006.

BONDUKI, Nabil. "Habitação na área central de São Paulo. Uma opção por uma cidade menos segregada, por um centro sem exclusão social”. In PMSP/Câmara Municipal. Relatório Final da Comissão de Estudos sobre Habitação na Área Central. São Paulo: Serviço gráfico da CMSP, setembro/2001.

BONDUKI, Nabil. Origens da Habitação Social no Brasil: arquitetura moderna, lei do inquilinato e difusão da casa própria. São Paulo: Estação Liberdade; FAPESP, 1998.

BONDUKI, Nabil; ANDRADE, Carlos R. M.; ROSSETTTO, Rossella (orgs). Arquitetura e Habitação Social em São Paulo 1989-1992. Publicação da exposição - II Bienal Internacional de Arquitetura de São Paulo. São Paulo: Fundação Bienal de S. Paulo, agosto 1993.

BOUCHE, Nancy. "A Reabilitação na França - instrumentos e procedimentos”. In LABHAB FAUUSP; École Nationale des Ponts at Chaussees; Pact Arim Internacional. Curso de Gestão de Programas de Reabilitação Urbana. São Paulo: FAUUSP, novembro de 2000. 
CALDEIRA, Teresa Pires do Rio. Cidade de Muros: crime, segregação e cidadania em São Paulo. São Paulo: Ed. 34; Edusp, 2000.

CASTELLS, Manuel \& BORJA, Jordi. “As Cidades como Atores Políticos”. In Revista Novos Estudos. São Paulo: Cebrap, no. 45, julho 1996, p. 152-166.

CERVELLATI, Pier Luigi; SACANNAVINI, Roberto e DE ANGELIS, Carlo. Bolonia: politica y metodologia de la restauración de centros históricos. Barcelona: Gili, 1976.

CHAUÍ, Marilena. “São Paulo - uma opção radial e moderna: Democracia Cultural”. In FARIA, H. e SOUZA, V. (orgs). Experiências de Gestão Cultural Democrática. Polis revista. São Paulo: Instituto Polis, n. 12, 1993, p. 9-38.

CLAVER, Nuria. “A Ciutat Vella de Barcelona: renovação ou gentrificação”. In BIDOU-ZACHARIASEN, Catherine (coord). De Volta à Cidade: dos processos de gentrificação às políticas de 'revitalização' dos centros urbanos. Tradução SILVA, Helena M. Barreto. São Paulo: Annablume, 2006.

COMIN, Álvaro A. "Diagnósticos, Oportunidades e Diretrizes de Ação". In PMSP/ EMURB. Caminhos para o Centro: estratégias de desenvolvimento para a região central de São Paulo. São Paulo: EMURB; Cebrap/CEM, 2004.

COULON, Jean-Yves. "Qual Procedimento Projetual, Qual Intervenção Pública em Bairros Históricos?” In LABHAB FAUUSP; École Nationale des Ponts at Chaussees; Pact Arim Internacional. Curso de Gestão de Programas de Reabilitação Urbana. São Paulo: FAUUSP, novembro de 2000.

COUTO, Edgar Tadeu Dias do. Estratégias Urbanisticas Aplicadas a Cidade de São Paulo em um Quadro de Gestão Redemocratizada: anos 80 e 90. Dissertação de Mestrado apresentada à Faculdade de Arquitetura e Urbanismo da Universidade de São Paulo. São Paulo: FAUUSP, 1999.

CURY, Isabelle (org). Cartas Patrimoniais. Brasília: IPHAN/Deprom, $3^{\mathrm{a}}$ edição, 2000.

DIOGO, Érica. Habitação Social no Contexto da Reabilitação da Área Central de São Paulo. Dissertação de Mestrado apresentada à Faculdade de Arquitetura e Urbanismo da Universidade de São Paulo. São Paulo: FAUUSP, 2004.

DEÁK, Csaba. Globalização on Crise Global. Paper apresentado no IX Encontro Nacional da ANPUR. Rio de Janeiro: 28/05 a 01/06/2001.

DEL RIO, Vicente. Introdução ao Desenho Urbano no Processo de Planejamento. São Paulo: PINI, 1990.

FARIA, Hamilton; SOUZA, Valmir de (orgs). Cidadania Cultural em São Paulo 1989-1992: leituras de uma política pública. Polis revista. São Paulo: Instituto Pólis, n. 28, 1997.

FELDMAN, Sarah. Planejamento e Zoneamento. São Paulo: 1947-1972. São Paulo: Editora da Universidade de São Paulo/Fapesp, 2005.

“São Paulo: qual centro?” In BONFATTI, D. e SCHICCHI, M. C. (orgs). Urbanismo: dossiê São Paulo - Rio de Janeiro. Campinas: PUCCAMP/PROURB, 2004.

FERNANDES, Ana Cristina. "Da Reestruturação Corporativa à Competição entre Cidades: lições urbanas sobre os ajustes de interesses globais e locais no capitalismo contemporâneo”. In NERU. Espaço \& Debates. Revista de Estudos Regionais e Urbanos. São Paulo: NERU, 2001, nº. 41, p. 26-45.

FERREIRA, João Sette Whitaker Ferreira. O Mito da Cidade-Global: o papel da ideologia na produção do espaço urbano. Petrópolis, RJ: Vozes; São Paulo: Editora Unesp; Salvador, BA: ANPUR, 2007.

Alcances e limitações dos Instrumentos Urbanísticos na construção de cidades democráticas e socialmente justas. $\mathrm{V}^{\mathrm{a}}$ Conferência das Cidades. Texto de apoio às discussões da Mesa 1. Brasília: Câmara Federal, dezembro de 2003.

Governança, um novo paradigma de gestão? Notas de uma palestra. In FAUUSP. Revista da Pós n. 9. São Paulo: FAUUSP, 2001. 
FERREIRA, João Sette Whitaker; FIX, Mariana. Urbanização e o Falso Milagre do CEPAC. Tendências e Debates. Folha de São Paulo. São Paulo: 17 de abril de 2001.

FERREIRA, João Sette Whitaker e MOTISUKE, Daniela. 2007. “A Efetividade de Implementação das Zonas Especiais de Interesse Social no Quadro Habitacional Brasileiro: uma avaliação inicial”. In BUENO, L. M. M e CYMBALISTA, R. Planos Diretores Municipais: novos conceitos de planejamento territorial. São Paulo: Annablume, 2007, p. 33-58.

FIX, Mariana. A "Fórmula Mágica" da "Parceria": Operações Urbanas em São Paulo. In Cadernos de Urbanismo, Secretaria Municipal de Urbanismo. Rio de Janeiro: ano 1, n. 3, 2000, p. 23-27.

FÓRUM CENTRO VIVO. Contribuições Preliminares para o Plano Reconstruir o Centro. Disponível em: www.forumcentrovivo.hpg.ig.com.br. Acessado em abril de 2007. São Paulo: junho 2001.

FREITAS, Marcelo de Brito A. P. “A Transferência do Potencial Construtivo: um novo instrumento de preservação e revalorização de áreas históricas. A experiência em São Paulo de 1984 a 1994”. In ZANCHETTI; MARINHO; MILLET (orgs). Estratégias de Intervenção em Áreas Históricas. Revalorização de áreas urbanas centrais. Recife: UFPE/PNUD, 1995.

FRÚGOLI JR, Heitor. Centralidade em São Paulo: trajetórias, conflitos e negociações na metrópole. São Paulo: Cortez, Edusp, 2000.

GARAY, Alfredo Maximo. "Puerto Madero, a montagem de uma intervenção urbana". In VIVA O CENTRO. Revista URBS n. 21. Disponível em: http://www.vivaocentro.org.br/publicacoes/urbs/urbs21.htm\#artigo. Acessado em setembro de 2007. São Paulo: AVC, abril/maio 2001.

GUERRA, Lisandra de Moura. Comentários sobre a Execução do Programa Ação Centro. Estágio de Avanço. In PMSP/EMURB. Ação Centro - Programa de Reabilitação do Centro de São Paulo. Mídia digital. São Paulo: EMURB, 2004.

HARVEY, David. “A Teoria Marxista do Estado”. In A Produção Capitalista do Espaço. São Paulo: Annablume, 2005 (a), p. 75-94.

"Do Administrativismo ao Empreendedorismo: a transformação da governança urbana no capitalismo tardio". In A Produção Capitalista do Espaço. São Paulo: Annablume, 2005 (b), p. 163-190.

A Condição Pós Moderna. Uma pesquisa sobre as origens da mudança cultural. SOBRAL, Adail Ubirajara; GONÇALVES, Maria Stela (trad). São Paulo: Edições Loyola, 1992.

"O Trabalho, o Capital e o Conflito de Classes em torno do Ambiente Construído nas Sociedades Capitalistas Avançadas”. In NERU. Espaço \& Debates, n. 6, São Paulo: jun/set 1982.

JACOBS, Jane. Morte e Vida de Grandes Cidades. Tradução Carlos S. Mendes Rosa. São Paulo: Martins Fontes, 2000.

KARA-JOSÉ, Beatriz. Política Cultural e Negócios Urbanos: a instrumentalização da cultura em intervenções urbanas na área central de São Paulo (1975 a 2000). São Paulo: Annablume, 2007.

KOHARA, Luiz. Rendimentos obtidos na locação e sublocação de cortiços - estudos de caso na área central da cidade de São Paulo. Dissertação de Mestrado apresentada à Escola Politécnica da Universidade de São Paulo. São Paulo: EP, 1999.

LABHAB; LILP; CAIXA. Observatório do Uso do Solo e da Gestão Fundiária do Centro de São Paulo. São Paulo: CAIXA, 2006.

LABHAB FAUUSP; École Nationale des Ponts er Chaussées; Pact-Arim Internacional. Gestão de Programas de Reabilitação Urbana. Textos referentes ao curso. São Paulo: LABHAB FAUUSP, 2000.

LEFEBVRE, Henri. A Cidade do Capital. Rio de Janeiro: DP \& A, 1999. 
LEFÈvRE, J. E. A. A Operação Urbana Centro. Relatoria da Palestra da $20^{a}$ Reunião do Clube das Idéias. São Paulo: Clube das Idéias, 1997.

LOPES, Felipe. "Reabilitação de Bairros Antigos em Lisboa". In LABHAB FAUUSP; École Nationale des Ponts at Chaussees; Pact Arim Internacional. Curso de Gestão de Programas de Reabilitação Urbana. São Paulo: FAUUSP, novembro de 2000 .

"Reabilitação Urbana em Lisboa". In Jornal Arquitectos. Publicação da Associação dos Arquitectos Portugueses, ano XIII, n. 151. Lisboa: Jornal Arquitectos, 1995, p. 24-29.

LUCINI, Hugo Camilo. Requalificação Urbana e Novos Assentamentos de Interesse Social. Tese de Doutorado apresentado à Faculdade de Arquitetura e Urbanismo da Universidade de São Paulo. São Paulo: FAUUSP, 1996.

MALTA, Candido; NAKANO, Kazuo; ROLNIK, Raquel. "Dinâmicas dos Subespaços da Área Central de São Paulo". In PMSP/EMURB. Caminhos para o Centro: estratégias de desenvolvimento para a região central de São Paulo. São Paulo: EMURB; Cebrap/CEM, 2004.

MARICATO, Ermínia. Brasil, Cidades: alternativas para a crise urbana. Petrópolis, RJ: Vozes, 2001.

"As Idéias Fora do Lugar e o Lugar Fora das Idéias: planejamento urbano no Brasil". In ARANTES, O.; VAINER, C.; MARICATO, E. Cidade do Pensamento Único: desmanchando consensos. Petrópolis: Vozes, 2000, p. 121-192.

MARICATO, Ermínia e FEREIRA, João Sette Whitaker. "Estatuto da Cidade: essa lei vai pegar?” In Correio da Cidadania. Disponível em: http://www.correiocidadania.com.br/ed252/politica.htm. Acessado em março de 2007. São Paulo: n. 252, julho de 2001.

MEYER, Regina. "Um Novo Modelo para a Recuperação da Área”. In VIVA O CENTRO, Associação. Pólo Lu₹. Sala São Paulo, Cultura e Urbanismo. São Paulo: Editora Terceiro Nome, 1999.

MEZA MOSQUEIRA, Tatiana. Reabilitação da região da Luz no centro histórico de São Paulo: Projetos urbanos e estratégias de intervenção. Dissertação de Mestrado apresentada à Faculdade de Arquitetura e Urbanismo da Universidade de São Paulo. São Paulo: FAUUSP, 2007.

MULLER, Nice Lecocq. "A Área Central da Cidade". In AZEVEDO, Aroldo. A Cidade de São Paulo: estudos de geografia urbana. Vol. 3 Aspectos da Metrópole Paulista. São Paulo: ABG, 1958, p. 121-182.

NOBRE, Eduardo Alberto Cuce. Reestruturação Econômica e Território: expansão recente do terciário na marginal do rio Pinheiros. Tese de Doutorado apresentada à Faculdade de Arquitetura e Urbanismo da Universidade de São Paulo. São Paulo: FAUUSP, 2000.

OLIVEIRA, Francisco. Crítica à Raz̃ão Dualista. O Ornitorrinco. São Paulo: Boitempo Editorial, 2003.

PADOVANI, Paula Wernecke. A Gestão Local na Reabilitação de Áreas Centrais: os casos de Lisboa e São Paulo. Dissertação de Mestrado apresentada à Faculdade de Arquitetura e Urbanismo da Universidade de São Paulo. São Paulo: FAUUSP, 2005.

PEÑA, Teodoro. "Empresa del Centro Histórico de Quito". In ROJAS, E. \& DAUGHTERS, R. (org). La ciudad en el siglo XXI. Simpósio de buenas prácticas em gestión urbana en América Latina y el Caribe. Washington D.C.: BID, 1998, p.87-91.

PEREIRA, Paulo César Xavier. "Dinâmica Imobiliária e Metropolização: a nova lógica do crescimento urbano em São Paulo”. In Anais do Colóquio Internacional de Geocrítica. Los Agentes Urbanos y Las Politicas sobre la Ciudad. Santiago de Chile: PUCC, maio 2005.

PERRIN, Jean-Bernard. "O Exemplo Francês da Proteção, do Remanejamento e da Valorização do Patrimônio Histórico Urbano". In SPHAN. Seminário sobre Restauração e Revitalização de Núcleos Históricos. Brasília: Minc/SPHAN/Pró-Memória, 1980, p. 12-26. 
PÓLIS/CARE. Controle social de politicas públicas: o financiamento do BID para a reabilitação do Centro de São Paulo. Relatório III. São Paulo: PÓLIS, novembro de 2007.

PORTAS, Nuno. "Notas sobre a Intervenção na Cidade Existente”. In FERREIRA, António Fonseca (dir). $A$ Cidade Existente. Sociedade e Território. Revista de Estudos Urbanos e Regionais. n. 2. Ano 1. Porto, PT: Edições Afrontamento, fevereiro 1985, p. 8-13.

PRUD'HOMME, Rémy. Estimating the Benefits of the Rehabilitation of São Paulo Downtown. Relatório de Consultoria para Ação Centro. São Paulo: BID/EMURB, 2002.

RIBEIRO, Luiz César de Queiroz e LAGO, Luciana Correa do. Reestruturação nas Grandes Cidades Brasileiras: o modelo centro-periferia em questão. Rio de Janeiro: IPPUR/UFRJ, 1994.

RODRIGUES, Marly. Imagens do Passado: a instituição do patrimônio em São Paulo. 1969-1987. São Paulo: Editora UNESP, Imprensa Oficial do estado, Condephaat, FAPESP, 2000.

ROJAS, Eduardo. Revitalización Urbana. In ROJAS, E. \& DAUGHTERS, R. (org). La ciudad en el siglo XXI. Simpósio de buenas prácticas em gestión urbana en América Latina y el Caribe. Washington D.C.: BID, 1998, p.73-77.

ROLNIK, Raquel. A Cidade e a Lei: legislação, política urbana e territórios na cidade de São Paulo. São Paulo: $2^{a}$ edição, Studio Nobel; FAPESP, 1999.

SALES, Pedro M. R. "Diagonal Sul”. In PMSP/EMURB Ação Centro - Programa de Reabilitação do Centro de São Paulo. Mídia digital. São Paulo: EMURB, 2004.

SASSEN, Saskia. As Cidades na Economia Mundial. Tradução de MOURA, Carlos Eugênio Marcondes de. São Paulo: Studio Nobel, 1998.

SEGRE, Roberto. "Múltiplas vozes em Barcelona". In Revista Projeto Design n. 296. São Paulo: arcoweb, outubro de 2004. Disponível em http://www.arcoweb.com.br/debate/debate71.asp

SILVA, Helena Menna Barreto. O centro de São Paulo: que futuro para a habitação? São Paulo: LILP, 2001.

SILVA, Helena Menna Barreto. Habitação no Centro de SP: como viabilizar essa idéia? Documento preparatório de encontro. São Paulo: LabHab FAUUSP; CAIXA, 2000.

“Aspectos da Dinâmica Imobiliária na Região Metropolitana de São Paulo no Período 67/97”. Relatório do Subprojeto III.2 - Levantamento das Transformações Imobiliárias na Fase Inicial da Linha 4: teste da base de informações secundárias. São Paulo: Metrô: 1999.

SILVA, Luis Octávio. "Decadência e Reabilitação do Centro de São Paulo". In PMSP/EMURB Ação Centro Programa de Reabilitação do Centro de São Paulo. Mídia digital. São Paulo: EMURB, 2004.

----------. A Reabilitação do Centro de São Paulo: aspectos estratégicos, territoriais e políticos. Anais Seminário Projetos Urbanos Contemporâneos no Brasil. Mídia digital. São Paulo: São Judas, 2005.

SILVA, Priscila Guerra Barbosa. Reabilitação de Áreas Centrais: São Paulo e o programa Ação Centro. Trabalho de Final de Graduação - TFG. Faculdade de Arquitetura e Urbanismo da USP. São Paulo: FAUUSP, 2005.

SMITH, Neil. “A Gentrificação Generalizada: de uma anomalia local a 'regeneração' urbana como estratégia urbana global”. In BIDOU-ZACHARIASEN, Catherine. De Volta à Cidade: dos processos de gentrificação às políticas de 'revitalização' dos centros urbanos. São Paulo: Annablume, 2006, p. 59-87.

SOMEKH, Nádia. "Agência de Desenvolvimento e Propostas para o Centro de São Paulo”. Entrevista concedida a Dênio Bonfatti em agosto de 2003. In BONFATTI, D. e SCHICCHI, M. C. (orgs). Urbanismo: dossiê São Paulo - Rio de Janeiro. Campinas: PUCCAMP/PROURB, 2004 (a).

"Programa Ação Centro: reconstruindo a área central de São Paulo". In PMSP/EMURB Ação Centro Programa de Reabilitação do Centro de São Paulo. Mídia digital. São Paulo: EMURB, 2004 (b). 
-. Prefácio. In PMSP/EMURB. Caminhos para o Centro: estratégias de desenvolvimento para a região central de São Paulo. São Paulo: EMURB; Cebrab/CEM, 2004 (c).

A Cidade Vertical e o Urbanismo Modernizador: São Paulo 1920 - 1939. São Paulo: Edusp, FAPESP, Nobel, 1997.

SOUZA, Clarissa Duarte de Castro. Planejamento Urbano e Políticas Públicas em Projetos de Requalificação de Áreas Portuárias: Porto de Santos - desafio deste novo século. Dissertação de Mestrado Apresentada à Faculdade de Arquitetura e Urbanismo da Universidade de São Paulo. São Paulo: FAUUSP, 2006.

SOUZA, Maria Adélia Aparecida. A Identidade da Metrópole: a verticalização em São Paulo. São Paulo: Edusp, Hucitec, 1994.

SOUZA, Valmir; GARCIA, Marinalda. "Patrimônio, Cidadania Cultural e Memória Social”. In FARIA, H. SOUZA, V. Cidadania Cultural em São Paulo 1989-1992. Leituras de uma política pública. Revista POLIS. São Paulo: Instituto Pólis, n. 28, 1997.

TTC Engenharia de Tráfego e de Transportes S/C Ltda. Estudos para a formulação de diretrizes para as ações relacionadas à circulação e acessibilidade e politica de implementação de garagens subterrâneas para a Área Central. Relatório de consultoria. São Paulo: EMURB, 2004.

TSUKUMO, Isadora Tami Lemos. Habitação Social no Centro de São Paulo: legislação, produção e discurso. Dissertação de Mestrado apresentada à Faculdade de Arquitetura e Urbanismo da Universidade de São Paulo. São Paulo: FAUUSP, 2007.

VAINER, Carlos. "Pátria, empresa e mercadoria". In ARANTES, O.; VAINER, C.; MARICATO, E. Cidade do Pensamento Único: desmanchando consensos. Petrópolis: Vozes, 2000, p. 75-103.

VAN WILDERODE, Daniel. Desregulamentação Urbana: as operações interligadas. Dissertação de Mestrado apresentada à Faculdade de Arquitetura e Urbanismo da Universidade de São Paulo. São Paulo: FAUUSP, 1994.

VILLAÇA, Flávio. As Ilusões do Plano Diretor. Disponível em: http://www.flaviovillaca.arq.br/pdf/ilusao_pd.pdf. Acessado em março de 2007. São Paulo: 2005.

. Espaço Intra-Urbano no Brasil. São Paulo: Studio Nobel; FAPESP; LILP, 2001.

“A Produção e o Uso da Imagem do Centro da Cidade: o caso de São Paulo." In ZANCHETTI, S; MARINHO, G; MILLET, V. Estratégias de Intervenção em Áreas Históricas: revalorização de áreas urbanas centrais. UFPE - Universidade Federal de Pernambuco, Recife, 1995.

VITALE, Letizia. et all. Perímetro de Reabilitação Integrada do Habitat - PRIH: uma experiência de intervenção nas áreas centrais. In: ANPUR - Associação Nacional de Pós-Graduação e Pesquisa em Planejamento Urbano e Regional. XI Encontro Nacional da ANPUR. Anais do encontro. Salvador: 2005.

VIVA O CENTRO, Associação. Proposta de Revisão dos Calçadões do Centro. São Paulo: AVC, 2005.

“A década em que São Paulo reencontrou o Centro". In Revista URBS n. 23. Disponível em: http://www.vivaocentro.org.br/publicacoes/urbs/urbs23.htm\#capa. Acessado em janeiro de 2007. São Paulo: AVC, out/nov 2001 (a).

- Os Centros das Metrópoles: reflexões e propostas para a cidade democrática do século XXI. São Paulo: Editora Terceiro Nome; AVC; Imprensa Oficial do Estado, 2001 (b).

--------. São Paulo Centro XXI: entre história e projeto. Seminário. São Paulo: AVC, 1994 (a).

-. Camelôs: subsídios para o equacionamento do problema do comércio informal de rua e sua solução. Documento final do workshop O Comércio Informal de Rua e a Requalificação do Centro de São Paulo. São Paulo: AVC, 1994 (b)

. Documento 1. São Paulo: AVC, 1993. 
ZANCHETI, Silvo Mendes. “Conservação Integrada e Planejamento Urbano na Atualidade”. In NERU, Espaço \& Debates n 43-44: Cidade, Cultura, (in) Civilidade. São Paulo: NERU, 2003, p. 92-104.

\section{Documentos Oficiais}

BRASIL (país)/MINISTÉRIO DAS CIDADES. Plano Diretor Participativo. Brasília: Ministérios das Cidades, dezembro 2005.

PMSP/Câmara Municipal. Relatório Final da Comissão de Estudos sobre Habitação na Área Central. São Paulo: Serviço gráfico da CMSP, setembro/2001.

PMSP/COGEP. Projeto Centro: investigações preliminares. São Paulo: COGEP, 1975.

PMSP/COGEP. Plano Integrado da Área Central de São Paulo. São Paulo: COGEP, 1976.

PMSP/COGEP. Rua de Pedestres. São Paulo: COGEP, 1974.

PMSP/EMURB. Ação Centro - Programa de Reabilitação da Área Central de São Paulo. Mídia digital (CD). São Paulo: EMURB, 2004 (a).

PMSP/EMURB. "Relatório de Projeto. Parque Dom Pedro II". In PMSP/EMURB. Ação Centro - Programa de Reabilitação do Centro de São Paulo. Mídia digital. São Paulo: EMURB, 2004 (b).

PMSP/EMURB. "Fórum de Desenvolvimento Social e Econômico do Centro da Cidade de São Paulo". Site-texto principal. In PMSP/EMURB. Ação Centro - Programa de Reabilitação do Centro de São Paulo. Mídia digital. São Paulo: EMURB, 2004 (c).

PMSP/EMURB. "Regulamento Operacional. Revisão 1/2004”. In PMSP/EMURB. Ação Centro - Programa de Reabilitação do Centro de São Paulo. Mídia digital. São Paulo: EMURB, 2004 (d).

PMSP/EMURB. Caminhos para o Centro: estratégias de desenvolvimento para a região central de São Paulo. São Paulo: EMURB; Cebrap/CEM, 2004 (e).

PMSP/EMURB. Concurso de Idéias para Renovação Urbana e Preservação do Bexiga: a cidade, o homem - uma identidade. Edital. São Paulo: EMURB, 1989.

PMSP/EMURB. A Cidade e o Automóvel. São Paulo: EMURB, 1979 (a).

PMSP/EMURB. Prédio Martinelli. São Paulo: EMRUB, 1979 (b).

PMSP/EMURB. Rua de Pedestres. São Paulo: EMURB, 1979 (c).

PMSP/EMURB. Reurbaniz̧ações. São Paulo: EMURB, 1979 (d)

PMSP/EMURB; BID. Programa Ação Centro. Plano de Ação para as Aquisições. Disponível em http://www.iadb.org/projects/Project.cfm?project=BR0391\&Language=Spanish. Acessado em novembro de 2007. São Paulo: EMURB; BID, 2004.

PMSP/EMURB; CEBRAP/CEM. Estratégias de desenvolvimento econômico para a área central do município de São Paulo. Diagnóstico da situação atual (1 ${ }^{a}$ etapa). São Paulo: Cebrap; EMURB, dezembro de 2002.

PMSP/EMURB; FIPE. Revisão dos Modelos de Monitoria e Avaliação. Revisão da Linha de Base. Programa de Reabilitação da Área Central de São Paulo - Ação Centro. Relatório Final. São Paulo: EMURB; FIPE, agosto 2006.

PMSP/EMURB; FIPE. Proposta para Execução da Linha de Base. Programa de Reabilitação da Área Central de São Paulo Ação Centro. São Paulo: EMURB; FIPE, 2003.

PMSP/EMURB; LUME. Impactos Econômicos e Sociais do Programa de Renovação do Centro. São Paulo: EMURB; LUME: 2003.

PMSP/SAS. "Construindo Inclusão Social desde as Ruas Centrais de São Paulo”. In PMSP/EMURB. Ação Centro Programa de Reabilitação do Centro de São Paulo. Mídia digital. São Paulo: EMURB, 2004. 
PMSP/SEHAB. Balanço Qualitativo de Gestão: 2001-2004. São Paulo: SEHAB, 2004 (a).

PMSP/SEHAB. Programa Morar no Centro. São Paulo: SEHAB, 2004 (b).

PMSP/SEHAB/COHAB/Morar no Centro. "Mecanismos de Incentivo para Atração de Famílias de Média Renda". In PMSP/EMURB. Ação Centro - Programa de Reabilitação da Área Central de São Paulo. Mídia Digital. São Paulo: EMURB, 2004.

PMSP/SEHAB/Programa Morar no Centro. Habitação no Centro: o programa da Prefeitura. São Paulo: SEHAB, outubro 2001.

PMSP/SEHAB/Programa Morar no Centro/Escritórios Antena PRIH Luz e PRIH Glicério. Documentos institucionais dos PRIH Luz e PRIH Glicério. São Paulo: 2004.

PMSP/SEHAB. Recuperando Sampa. Reabilitação do Centro de São Paulo. São Paulo: SEHAB, 1992.

PMSP/SEHAB/PROCENTRO. Carta-Consulta à COFIEX - Comissão de Financiamentos Externos. Programa de Valorização do Centro. Versão III. São Paulo: SEHAB, maio 1997 (a).

PMSP/SEHAB/PROCENTRO. Cartilha da Área Central. São Paulo: 1997 (b).

Carta-Consulta à COFIEX - Comissão de Financiamentos Externos. Programa de V alorização do Centro. São Paulo: SEHAB, julho 1996.

PMSP/SEHAB/PROCENTRO/AR-SÉ. Justificativa para Alteração da Carta-Consulta Encaminhada à COFIEX Comissão de Financiamentos Externos. São Paulo: PROCENTRO/AR-SÉ, 2001a.

Reconstruir o Centro: reconstruir a cidade e a cidadania. São Paulo: AR-SÉ, 2001 b.

PMSP/SEMPLA. São Paulo Crise e Mudança. São Paulo: Brasiliense, 1991 (a).

PMSP/SEMPLA. Plano Diretor de São Paulo. Ao alcance de todos. São Paulo: SEMPLA, 1991 (b).

PMSP/SEMPLA. Plano Diretor do Município de São Paulo 1985-2000. São Paulo: 1985 (a).

PMSP/SEMPLA. Cortiço em São Paulo, frente e verso. São Paulo: SEMPLA, 1985 (b).

PMSP/SMC/DPH. Palácio das Indústrias. Memória e Cidadania: o restauro para a nova prefeitura de São Paulo. São Paulo: DPH/Método, 1992.

PMSP/SMT/SPTrans. "Programa Ação Centro: Transporte e Circulação". In PMSP/EMURB. Ação Centro Programa de Reabilitação da Área Central de São Paulo. Mídia digital. São Paulo: EMURB, 2004.

\section{Textos Legais}

BRASIL. Lei Federal n. 10.257 de 10 de julho de 2001 - Estatuto da Cidade. Estabelece diretrizes da política urbana no Brasil. Brasília: Câmara dos Deputados, 2001.

BRASIL. Constituição da República Federativa do Brasil de 1988. São Paulo: Coleção Saraiva de Legislação, 2001.

SÃO PAULO (município). Lei Municipal 13.885 de 25 de agosto de 2004. Estabelece normas complementares ao Plano Diretor Estratégico, institui os Planos Regionais Estratégicos das Subprefeituras, dispõe sobre o parcelamento, disciplina e ordena o uso e ocupação do solo do município de São Paulo (Lei de Uso e Ocupação do Solo - LUOS). São Paulo: Diário Oficial, 6 de outubro de 2004.

SÃO PAULO (município). Decreto Municipal 44.667 de 26 de abril de 2004. Regulamenta disposições da Lei Municipal 13.430/02, que institui Plano Diretor Estratégico, relativas a Zonas Especiais Interesse Social - ZEIS, respectivos Planos de Urbanização, e dispõe sobre normas específicas para a produção de Empreendimentos de Habitação Interesse Social - EHIS, Habitação de Interesse Social - HIS e Habitação Mercado Popular - HMP. São Paulo: Diário Oficial, 27 de abril de 2004. 
SÃO PAULO (município). Decreto Municipal 44.493 de 15 de março de 2004. Regulamenta a Lei Municipal 13.496/03 (Lei de Incentivos Seletivos - gestão Marta), que dispõe sobre a criação do Programa de Incentivos Seletivos para a área central do Município de São Paulo, nos termo que especifica. São Paulo: Diário Oficial, 16 de março de 2004.

SÃO PAULO (município). Decreto Municipal 44.401 de 19 de fevereiro de 2004. Cria, no âmbito da Secretaria da Habitação e Desenvolvimento Urbano, os Comitês de Reabilitação, para atuar nos Perímetros de Reabilitação Integrada do Habitat - PRIH. São Paulo: Diário Oficial, 20 de fevereiro de 2004.

SÃO PAULO (município). Decreto Municipal 44.089 de 10 de novembro de 2003. Institui o Fórum de Desenvolvimento Social e Econômico do Centro de São Paulo e a Coordenação Executiva Ação Centro, junto à EMRUB, bem como cria o Grupo Técnico - Agência de Desenvolvimento do Centro de São Paulo, vinculado à Diretoria de Desenvolvimento da EMURB. São Paulo: Diário Oficial, 11 de novembro de 2003.

SÃO PAULO (município). Decreto Municipal 44.090 de 10 de novembro de 2003. Atribui à EMURB a execução, a administração e a coordenação do Programa de Reabilitação da Área Central da Cidade de São Paulo PROCENTRO, e dá outras providências. São Paulo: Diário Oficial, 11 de novembro de 2003.

SÃO PAULO (município). Lei Municipal n. 13.496 de 7 de janeiro de 2003. Dispõe sobre a criação do Programa de Incentivos Seletivos para a área central do Município de São Paulo, nos termos que especifica (gestão Marta). São Paulo: Diário Oficial, 8 de janeiro de 2003.

SÃO PAULO (município). Lei Municipal 13.430 de 13 de setembro de 2002. Regulamenta o Plano Diretor Estratégico do Município de São Paulo. São Paulo: Diário Oficial, 14 de setembro de 2002.

SÃO PAULO (município). Decreto Municipal 37.302 de 27 de janeiro de 1998. Regulamenta a Lei de Fachadas (LM 12.350/97). São Paulo: Diário Oficial, 28 de janeiro de 1998.

SÃO PAULO (município). Lei Municipal 12.350 de 6 de junbo de 1997 (Projeto de Lei n. 604/93, do Executivo). (Lei de Fachadas). Concede incentivo fiscal aos proprietários de imóveis ou aos patrocinadores das obras de recuperação externa e conservação de imóveis localizados na Área Especial de Intervenção, objeto do Programa de Requalificação Urbana e Funcional do Centro de São Paulo - PROCENTRO, ou outro equivalente que venha a ser implantado. São Paulo: Diário Oficial, 7 de junho de 1997.

SÃO PAULO (município). Lei Municipal 12.349 de 6 de junho de 1997 (Projeto de Lei no 901/1993, do Executivo Municipal) (Lei da Operação Urbana Centro). Estabelece programa de melhorias para a área central da cidade, cria incentivos e formas para a sua implantação. São Paulo: Diário Oficial, 7 de junho de 1997.

SÃO PAULO (município)/Diário Oficial. Suplemento PROCENTRO - Programa de Requalificação Urbana e Funcional do Centro de São Paulo. São Paulo: Diário Oficial, 15 de julho de 1993.

SÃO PAULO (município). Decreto Municipal 33.389 de 14 de julho de 1993. Dispõe sobre a criação do Programa de Requalificação Urbana e Funcional do Centro de São Paulo - PROCENTRO, a ser implantado na Área Especial de Intervenção, que especifica, e da outras providências. São Paulo: 15 de dezembro de 1993.

SÃO PAULO (município). Decreto Municipal 31.601 de 26 de maio de 1992. Decreto de Habitação de Interesse Social, que regulamenta os critérios urbanísticos e de edificação para elaboração e implementação de projetos de empreendimentos habitacionais de interesse social. São Paulo: Diário Oficial, 27 de maio de 1992.

SÃO PAULO (município). Lei Municipal 11.090 de 16 de setembro de 1991. Operação Urbana Anhangabaú. Estabelece programas de melhorias para a área de influência imediata do Vale do Anhangabaú, cria incentivos e formas para sua implantação. São Paulo: Diário Oficial, 17 de setembro de 1991.

SÃO PAULO (município). Lei Municipal 10.928 de 8 de janeiro de 1991. (Lei Moura) Dispõe sobre as condições de habitação dos cortiços e habitações coletivas, estabelecendo parâmetros mínimos de habitabilidade. São Paulo: Diário Oficial, 9 de janeiro de 1991. 


\section{Obras Consultadas}

CENTRO VIVO, FÓRUM. Violação dos Direitos Humanos no Centro de São Paulo: propostas e reivindicações para políticas públicas. Dossiê Denúncia. São Paulo: FCV, junho de 2006.

DAL PIAN, Lílian de Almeida. Revitalização de Áreas Portuárias: o caso de Docklands. Dissertação de Mestrado apresentada à Faculdade de Arquitetura e Urbanismo da Universidade de São Paulo. São Paulo: FAUUSP, 2005.

LEFÈVRE, José E. Assis. "Um Ano de Operações Urbanas". In PMSP/EMURB. Política e Obras Fortalecem a Cidadania. São Paulo: EMURB, 1992.

. O Transporte Coletivo como Agente Transformador da Estruturação do Centro da Cidade de São Paulo. Dissertação de Mestrado apresentada à Faculdade de Arquitetura e Urbanismo da Universidade de São Paulo. São Paulo: FAUUSP, 1985.

LEME, Maria Cristina da Silva. Revisão do Plano de Avenidas: um estudo sobre o planejamento urbano em São Paulo em 1930. Tese de Doutorado apresentada a Faculdade de Arquitetura e Urbanismo da Universidade de São Paulo. São Paulo: FAUUSP, 1990.

MARICATO, Ermínia. Metrópole na Periferia do Capitalismo: ilegalidade, desigualdade e violência. São Paulo: Hucitec, 1996.

MARQUES, Juliana Di Cesare Margini. Clusters e Inovação Urbana: novas possibilidades de regeneração urbana e reestruturação produtiva. Análise de projetos inovativos. Dissertação de Mestrado apresentada a Faculdade de Arquitetura e Urbanismo da Universidade Presbiteriana Mackenzie. São Paulo, 2005.

PICCINI, Andrea. Cortiços na Cidade: conceito e preconceito na reestruturação do centro urbano de São Paulo. São Paulo: Annablume, 1999.

PMSP/COGEP. Política Institucional. Política de Habitação e Renovação Urbana. Política de Desenvolvimento da Área Central. Série Documentos. São Paulo: COGEP, 1979.

PMSP/EMURB. Relatório da Diretoria. São Paulo: EMURB, 1979.

PMSP/SEHAB/SMC/SEMPLA/AR-SÉ. Eixo Sé-Arouche. Programa Piloto de Ordenação da Paisagem da Área Central. São Paulo: SEHAB, 1992.

PMSP/SEMPLA (org). Plano Diretor Estratégico do Município de São Paulo 2002-2012. São Paulo: Editora SENAC São Paulo / Prefeitura Municipal de São Paulo: 2004.

SIMÕES JR, José Geraldo. Revitalização de Centros Urbanos. Revista Polis. São Paulo: Instituto Polis, n. $19,1994$.

SOMEKH, Nádia e CAMPOS, Candido Malta (orgs). A Cidade que Não Pode Parar: planos urbanísticos de São Paulo no século XX. São Paulo: Editora Mackpesquisa, 2002.

TOURINHO, Andréa. Do Centro aos Centros: bases teórico-conceituais para o estuda da centralidade em São Paulo. Tese de Doutorado apresentada à Faculdade de Arquitetura e Urbanismo da Universidade de São Paulo FAUUSP. São Paulo, 2004.

VILLAÇA, Flávio. "Uma Contribuição para a História do Planejamento Urbano no Brasil”. In DEÀK, C. e SCHIFFER, S. (orgs) O Processo de Urbanização no Brasil. São Paulo: Edusp, Fupam, $1^{\text {a }}$ ed. $1^{\text {a }}$ reimpressão, 2004, p.167-243.

VIVA O CENTRO, Associação. Os Centros das Metrópoles: reflexões e propostas para a cidade democrática do século XXI. São Paulo: Editora Terceiro Nome; AVC; Imprensa Oficial do Estado, 2001.

São Paulo Centro: uma nova abordagem. São Paulo: AVC, 2000.

Pólo Luz: Sala São Paulo, Cultura e Urbanismo. São Paulo: Editora Terceiro Nome, 1999. 


\section{ANEXOS}

Anexo 1: Carta-consulta (1997) - Custos Totais dos Projetos (US\$ mil) ………………………………....... 212

Anexo 2: Justificativa para Alteração de Carta-Consulta (2001) - Ações e Custos (US\$ mil) ...................... 213

Anexo 3: Ação Centro (2004) - Projetos Específicos .......................................................................................... 214

Anexo 4: Ação Centro (2004) - Indicadores de Avaliação de Efeito e Impacto ............................................. 216 
Anexo 1: Carta-consulta (1997) - Custos Totais dos Projetos (US\$ MIL)

\begin{tabular}{|c|c|c|c|}
\hline & COMPONENTES/INTERVENÇÕES & $\begin{array}{l}\text { CUSTOS } \\
\text { TOTAIS }\end{array}$ & $\%$ \\
\hline (A) & Informação e Gestão Urbana & $9.040,00$ & $5 \%$ \\
\hline A.1. & Sistema de Apoio à Decisão (GIS) & 400,00 & $0 \%$ \\
\hline A.2. & Fiscalização, Controle a Apoio às Medidas de Conservação & $1.200,00$ & $1 \%$ \\
\hline A.3. & Seminários Técnicos Nacionais e Internacionais & 940,00 & $0 \%$ \\
\hline A.4. & Estudos de Circulação & $1.500,00$ & $1 \%$ \\
\hline A.5. & Gerenciamento e Fiscalização & $5.000,00$ & $2 \%$ \\
\hline (B) & Desenvolvimento Social, Econômico e Ambiental & $75.834,00$ & $38 \%$ \\
\hline B.1. & Eixo de Eventos & $24.584,00$ & $12 \%$ \\
\hline B.1.1. & Anhangabaú/Praça Ramos & $2.500,00$ & $1 \%$ \\
\hline B.1.2. & Avenida São João & 550,00 & $0 \%$ \\
\hline B.1.3. & Largo da Memória & $1.250,00$ & $1 \%$ \\
\hline B.1.4. & Largo do Arouche & $6.345,00$ & $3 \%$ \\
\hline B.1.5 & Largo do Paissandú & 630,00 & $0 \%$ \\
\hline B.1.6 & Largo São Francisco & 550,00 & $0 \%$ \\
\hline B.1.7 & Pátio do Colégio & 530,00 & $0 \%$ \\
\hline B.1.8 & Praça Dom José Gaspar & $1.050,00$ & $1 \%$ \\
\hline B.1.9 & Praça da República & $1.500,00$ & $1 \%$ \\
\hline B.1.10. & Praça do Patriarca & 300,00 & $0 \%$ \\
\hline B.1.11. & Praça Roosevelt & $5.239,00$ & $3 \%$ \\
\hline B.1.12. & Viaduto do Chá & $2.000,00$ & $1 \%$ \\
\hline B.1.13. & Viaduto Santa Ifigênia/Avenida Cásper Libero & $2.140,00$ & $1 \%$ \\
\hline B.2. & Acessibilidade aos Portadores de Deficiências & $2.750,00$ & $1 \%$ \\
\hline B.3. & Núcleos de Cidadania/Equipamentos Sociais (saúde e educação) & $8.000,00$ & $4 \%$ \\
\hline B.4. & Igrejas e Espaços Culturais & $7.500,00$ & $4 \%$ \\
\hline B.5. & Educação e Cultura & $33.000,00$ & $16 \%$ \\
\hline B.5.1. & Galeria Prestes Maia & $5.000,00$ & $2 \%$ \\
\hline B.5.2. & Parque Dom Pedro II & $28.000,00$ & $14 \%$ \\
\hline (C) & Infra-Estrutura & $91.368,00$ & $46 \%$ \\
\hline C.1. & Garagens Subterrâneas & $47.850,00$ & $24 \%$ \\
\hline C.1.1. & Arouche & $9.600,00$ & $5 \%$ \\
\hline C.1.2. & Correios & $5.500,00$ & $3 \%$ \\
\hline C.1.3. & Mercado & $8.250,00$ & $4 \%$ \\
\hline C.1.4. & Pátio do Colégio & $5.200,00$ & $3 \%$ \\
\hline C.1.5. & Praça Antônio Prado & $7.050,00$ & $4 \%$ \\
\hline C.1.6. & Praça João Mendes & $6.000,00$ & $3 \%$ \\
\hline C.1.7. & Rua Coronel Xavier de Toledo & $6.250,00$ & $3 \%$ \\
\hline C.2. & Adequações Viárias no Largo do Arouche & $16.200,00$ & $8 \%$ \\
\hline C.3. & Adequações Viárias no Parque Dom Pedro II & $2.000,00$ & $1 \%$ \\
\hline C.4. & Adequações Viárias na Praça Roosevelt & $8.818,00$ & $4 \%$ \\
\hline C.5. & Corredor Mooca/Luz & $15.000,00$ & $7 \%$ \\
\hline C.6. & Anel Central & $1.500,00$ & $1 \%$ \\
\hline (D) & Revitalizações Urbanas & $24.500,00$ & $12 \%$ \\
\hline D.1. & Zona Cerealista & $5.000,00$ & $2 \%$ \\
\hline D.2. & Pátio do Pari & $3.000,00$ & $1 \%$ \\
\hline D.3. & Área da Estação Júlio Prestes & $6.000,00$ & $3 \%$ \\
\hline \multirow[t]{2}{*}{ D.4. } & Área da Estação da Luz & $10.500,00$ & $5 \%$ \\
\hline & TOTAL & $200.742,00$ & $100 \%$ \\
\hline
\end{tabular}

US\$1,00 = R \$ 1,019 (setembro de 1996)

Fonte: PMSP/SEHAB/PROCENTRO, 1997: 12. 
Anexo 2: Justificativa para Alteração de Carta-Consulta (2001) - AÇões E Custos (US\$ MIL)

\begin{tabular}{llcc}
\hline COMPONENTES / INTERVENÇÕES & CUSTOS & CUSTOS \\
PARCIAIS & TOTAIS & $\%$ \\
\hline (A) & Informações $\boldsymbol{e}$ Gestão Urbana & & $\mathbf{9 . 1 0 0}$ \\
\hline & (Programas Cuidar e Governar o Centro) & 400 \\
\hline A1. & Sistemas de Apoio à Decisão & 2.500 & \\
\hline A2. & Elaboração de Estudos Inter-setoriais & & \\
\hline & $\begin{array}{l}\text { Implantação e Acompanhamento de Programas: Escritórios técnicos; Escola de } \\
\text { cidadania urbana; Centros de informação turística; Educação ambiental e }\end{array}$ & 2.000 &
\end{tabular}

A3. cidadania urbana; Centros de informação turística; Educação ambiental e 2.000 patrimonial

Gerenciamento e Fiscalização: Uso e ocupação do espaço público; Uso e

A4. ocupação de imóveis privados; Serviços urbanos; Imóveis preservados; Atribuição de Selo

\begin{tabular}{|c|c|c|c|}
\hline A5. & Seminários Técnicos Nacionais e Internacionais & 200 & \\
\hline (B) & Desenvolvimento Social Econômico e Ambiental & 77.400 & 38,59 \\
\hline & (Programa Andar no Centro) & & \\
\hline
\end{tabular}
Recuperação de praças e passeios públicos: Recuperação de calçadas (padronização de calçamento, transposição de desníveis e barreiras geográficas, iluminação, arborização, reordenação de mobiliário urbano, sinalização de horários e percursos de transporte coletivo, melhoria da sinalização turística,

B1. recuperação de banheiros públicos); Recuperação de praças e largos (paisagismo, equipamentos de lazer, restauro); Adequação para acessibilidade dos portadores de deficiência (demarcação de estacionamentos e acessos); Rebaixamento de guias e passeios; Reorganização de mobiliário urbano; Adequação de edificações públicas; Sinalização. (Programa Morar no Centro)

B2. Produção de unidades habitacionais: Construção de novas edificações; Reforma de edifícios vazios; Locação Social; Melhorias em cortiços. (Programas Preservar o Centro e Descobrir o Centro)

25.000 10.000

B3. Preservação, restauro e dinamização de uso de bens e espaços públicos. ?? (Programa Trabalhar no Centro)

Capacitação de mão de obra para serviços urbanos: Capacitação de moradores de rua - fábrica de vassouras, manutenção de jardins, produção de uniformes,

B4. reforma de calçadas; Capacitação para trabalho em reciclagem de lixo; 400

Capacitação de profissionais de turismo; Capacitação de agentes de recreação;

Capacitação para preservação do patrimônio.

\begin{tabular}{|c|c|c|c|c|}
\hline B5. & Equipamentos sociais & ?? & & \\
\hline \multirow[t]{2}{*}{ (C) } & Infra-Estrutura & & 90.237 & 44,99 \\
\hline & (Programa Andar no Centro) & & & \\
\hline C1. & $\begin{array}{l}\text { Melhorias viárias: Recuperação de viadutos e elevados; Implantação da contra- } \\
\text { rótula; Melhorias de tráfego e transporte coletivo; Readequação de pontos de } \\
\text { táxi, ônibus e carga e descarga. }\end{array}$ & 68237 & & \\
\hline C2. & Recuperação de Galerias de Drenagem & 9.000 & & \\
\hline C3. & Implantação de duas garagens subterrâneas: centro novo e centro velho & 13.000 & & \\
\hline \multirow[t]{2}{*}{ (D) } & Revitalizações Urbanas & & 23.805 & 11,87 \\
\hline & (Programas Investir no Centro e Morar no Centro) & & & \\
\hline D1. & Perímetros de reabilitação integrada do habitat (PRIH) & 1.888 & & \\
\hline D2. & Aproveitamento da área da Favela do Gato & 5.555 & & \\
\hline D3. & Orla ferroviária e Pátio do Pari & 5.000 & & \\
\hline D4. & Parque Dom Pedro II & 2.422 & & \\
\hline D5. & Rua 25 de Março & 3.000 & & \\
\hline D6. & Mercado Municipal & 740 & & \\
\hline D7. & Zona Cerealista. & 4.000 & & \\
\hline D8. & Área da Santa Ifigênia & 1.200 & & \\
\hline & TOTAL & & 200.542 & 100,00 \\
\hline
\end{tabular}

Fonte: PMSP/SEHAB/PROCENTRO/ARSÉ, 2001:9 
Anexo 3: AÇÃo Centro (2004) - Projetos Específicos

\begin{tabular}{|c|c|c|c|}
\hline \multirow{2}{*}{$\begin{array}{l}\text { (Cores } \\
\text { conforme } \\
\text { gráfico 1) }\end{array}$} & Projeto & Executor & $\begin{array}{c}\text { Investimentos } \\
\text { estimativa (U\$ } \\
\text { mil) }\end{array}$ \\
\hline & $\begin{array}{l}\text { Reversão da Desvalorização Imobiliária do Centro e Recuperação da } \\
\text { Função Residencial }\end{array}$ & & \\
\hline \multirow[t]{8}{*}{1.0} & Reabilitação do Parque Dom Pedro & & \\
\hline & Parque I Etapa & Sub-Sé & 2.707 \\
\hline & Zeladoria na área do Parque & Sub-Sé & 2.857 \\
\hline & Mercado & SEMAB & 6.357 \\
\hline & Palácio das Indústrias - MUSEU DA CIDADE & SMC & 1.945 \\
\hline & Casa das Retortas & SGM/Anhembi & 857 \\
\hline & Edifício São Vito & SEHAB & 1.43 \\
\hline & Viário & SMT & 2.987 \\
\hline \multirow[t]{10}{*}{2.0} & Transformação do Perfil Econômico do Centro & & \\
\hline & Regularização do Comércio Informal & & \\
\hline & Reordenamento & EMURB & 860 \\
\hline & Operação Trabalho & SDTS & 663 \\
\hline & Capacitação ocupacional & SDTS & 500 \\
\hline & São Paulo Inclui & SDTS & 94 \\
\hline & Oportunidade solidária & SDTS & 245 \\
\hline & Bases de Vigilância Comunitária & SMSU & 1.492 \\
\hline & Atenção a Grupos Vulneráveis & & \\
\hline & Presença social nas ruas & SAS & 1.143 \\
\hline \multirow[t]{33}{*}{3.0} & Recuperação do Ambiente Urbano & & \\
\hline & Requalificação do Espaço Público & & \\
\hline & Gestão do Centro & Sub-Sé & 5.342 \\
\hline & Reurbanização & & \\
\hline & República & Sub-Sé & 548 \\
\hline & Sé & Sub-Sé & 700 \\
\hline & Roosevelt & EMURB & 1.143 \\
\hline & Calçadão do Largo São Francisco & EMURB & 629 \\
\hline & Ruas Comerciais & & \\
\hline & Casper Líbero & SMSP & 538 \\
\hline & Santa Ifigênia & SMSP & 301 \\
\hline & São Caetano & SMSP & 802 \\
\hline & 25 de Março & SMSP & 1224 \\
\hline & Circuito de compras & Anhembi & 420 \\
\hline & Iluminação de logradouros e monumentos & SIURB & 3084 \\
\hline & Requalificação de Edifícios Públicos & & \\
\hline & Biblioteca Mario de Andrade & SMC & 6.358 \\
\hline & Edifício Martinelli & EMURB & 2.286 \\
\hline & Teatro Municipal & Sub-Sé & 171 \\
\hline & Museu do Teatro Municipal & SMC & 171 \\
\hline & Revitalização da Galeria Formosa & SMC & 57 \\
\hline & Casas Históricas: Solar da Marquesa/Casa $\mathrm{n}^{\circ} 1 /$ Beco do Pinto $^{2}$ & SMC & 286 \\
\hline & CEJUR & SJ & 70 \\
\hline & PATR & SJ & 1.280 \\
\hline & Controle de Inundações & & \\
\hline & Piscinão da Praça da Bandeira & SIURB & 8.479 \\
\hline & Piscinão da Praça 14 Bis & SIURB & 8.115 \\
\hline & Galeria 9 de Julho Córrego do Saracura & SIURB & 4.461 \\
\hline & Galeria Moringuinho & SIURB & 1.213 \\
\hline & Resíduos Sólidos Recicláveis & & \\
\hline & Central de Triagem & SSO & 659 \\
\hline & Gestão de Entulho & SSO & 809 \\
\hline & Feira Limpa & SSO & 64 \\
\hline \multirow[t]{4}{*}{4.0} & Circulação e Transportes & & \\
\hline & Circulação e acessibilidade & SMT & 2.414 \\
\hline & Transporte Público & & \\
\hline & Intervenções Viárias - 1a. Fase & & \\
\hline
\end{tabular}




\begin{tabular}{|c|c|c|}
\hline Projetos & SMT & 429 \\
\hline Rótula Definitiva & SMT & 7.394 \\
\hline Contra-Rótula Operacional & SMT & 2.441 \\
\hline Contra-Rótula Definitiva (N/O) & SMT & 1.297 \\
\hline Conexão Rótula-Contra-Rótula (P.D. Pedro II) & SMT & 1.034 \\
\hline Viários de Aproximações (NE, N, SO, SE, Bresser) & SMT & 2.217 \\
\hline \multicolumn{3}{|l|}{ Intervenções Viárias - 2a. Fase } \\
\hline Projetos & SMT & 186 \\
\hline Contra-Rótula Definitiva (N/O) & SMT & 6.159 \\
\hline Ligações Viárias & SMT & 572 \\
\hline Terminal Bandeira & SMT & 4.429 \\
\hline Equipamentos de Monitoramento & SMT & 429 \\
\hline Estações de Transferência & SMT & 1.143 \\
\hline \multicolumn{3}{|l|}{ Operação de Trânsito e Melhorias no Sistema Viário } \\
\hline Equipamentos & SMT & 2.300 \\
\hline Serviços de Gerenciamento & SMT & 255 \\
\hline Melhorias Viárias na Foz do Tamanduateí & SIURB & 5.278 \\
\hline
\end{tabular}

Fonte: PMSP/EMURB 2004d (Quadro IV-1), com complementação da autora para legenda em cores. 


\section{ANEXo 4: AÇÃo CENTro (2004) - INDICADORES dE AVALIAÇÃo DE EFEITO E IMPACTO ${ }^{137}$}

\begin{tabular}{|c|c|c|}
\hline Indicador de Avaliação & Informação & Fonte \\
\hline \multicolumn{3}{|c|}{ Finalidade - "promover o desenvolvimento social e econômico, com diversidade, da área central de São Paulo" } \\
\hline $\begin{array}{l}\text { Especialização econômica terciária na área central igual ou maior que no restante da } \\
\text { cidade, a partir de } 2006\end{array}$ & valor do produto agregado, por setor & RAIS, PNAD, SEADE \\
\hline $\begin{array}{l}\text { Variação do tamanho do mercado efetivo do trabalho na área central de } 0,5 \% \text { no final do } \\
\text { programa (menor de } 60 \text { minutos de deslocamento do centro) }\end{array}$ & Emprego e tempo de deslocamento & $\begin{array}{l}\text { Pesquisa OD, SEADE, } \\
\text { IBGE }\end{array}$ \\
\hline $\begin{array}{l}\text { Variação dos salários gerados na área central maior ou igual que no restante da cidade, a } \\
\text { partir de } 2006 *\end{array}$ & valor dos salários gerados na área central e no município & RAIS, PNAD \\
\hline \multicolumn{3}{|c|}{ Propósito - "criar, manter e tornar mais atraente as condições para o exercício de atividades privadas legais na área central de SP" } \\
\hline $\begin{array}{l}\text { Variação do valor lançado de ISS/ITBI/ICMS na área central igual ou maior que o } \\
\text { restante da cidade, a partir do segundo ano de execução }\end{array}$ & valor do ISS, ITBI, ICMS na área central e no município & $\begin{array}{l}\text { Secretaria Mun. de } \\
\text { Finanças e Secretaria } \\
\text { Fazenda do Estado }\end{array}$ \\
\hline $\begin{array}{l}\text { Variação do consumo de energia elétrica na área central igual ou maior que do restante da } \\
\text { cidade, por tipo de consumidor (residenciais, comerciais etc.), a partir do segundo ano de } \\
\text { execução }\end{array}$ & $\begin{array}{l}\text { consumo de energia elétrica na área central e no restante do } \\
\text { município, por tipo de usuário }\end{array}$ & $\begin{array}{l}\text { Eletropaulo, CPFL, } \\
\text { Piratininga/Bandeirante } \\
\mathrm{s}\end{array}$ \\
\hline \multicolumn{3}{|l|}{ Reverão da Desvalorização Imobiliária e Recuperação da Função Residencial } \\
\hline $\begin{array}{l}\text { Variação no VALOR DE MERCADO dos imóveis residenciais e não residenciais maior } \\
\text { ou igual do restante do município, a partir do segundo ano de execução }\end{array}$ & valor da locação dos imóveis residenciais e não residenciais & $\begin{array}{l}\text { Pesquisa de Campo } \\
\text { FIPE }\end{array}$ \\
\hline $\begin{array}{l}\text { Diminuição da TAXA DE DESOCUPAÇÃO dos imóveis residenciais em relação à } \\
\text { linha de base, a partir do segundo ano de execução }\end{array}$ & Número de imóveis residenciais vazios & $\begin{array}{ll}\text { Pesquisa de Campo } \\
\text { FIPE }\end{array}$ \\
\hline $\begin{array}{l}\text { Variação de } 10 \% \text { da SUPERFÍCIE APROVADA para construções e reformas de } \\
\text { imóveis residenciais em relação à linha de base, a partir do segundo ano de execução do } \\
\text { projeto }\end{array}$ & $\begin{array}{l}\text { área da superfície aprovada para construções e reforma de } \\
\text { imóveis residenciais }\end{array}$ & SEHAB/APROV \\
\hline \multicolumn{3}{|l|}{ Transformação do Perfil Econômico do Centro } \\
\hline $\begin{array}{l}\text { Variação da arrecadação do ICMS e ISS, por setor, maior ou igual ao restante da cidade, a } \\
\text { partir do segundo ano de execução do programa }\end{array}$ & valor do ICMS arrecadado & $\mathrm{SF}$ \\
\hline $\begin{array}{l}\text { Aumento de } 30 \% \text { das emissões de ALVARÁ DE FUNCIONAMENTO em relação ao } \\
\text { ano de } 2000 \text {, no quinto ano de execução do projeto }\end{array}$ & número de alvarás de funcionamento emitidos & SEHAB \\
\hline $\begin{array}{l}\text { CONHECIMENTO DA POPULAÇÃO da cidade dos avanços e resultados do } \\
\text { programa a partir de julho de } 2005\end{array}$ & $\begin{array}{l}\text { realizações do programa Ação Centro de conhecimento da } \\
\text { população }\end{array}$ & $\begin{array}{lll}\text { Pesquisa de Campo } \\
\text { FIPE }\end{array}$ \\
\hline
\end{tabular}

${ }^{137}$ Esses indicadores foram utilizados para a elaboração da Linha de Base do programa e deveriam ser utilizados para as avaliações anuais e final. 
Crescimento do atendimento e encaminhamento de crianças e adolescentes em situação de por agentes nas ruas do centro em relação à linha de base, nas diferentes modalidades de atenção

Crescimento da proporção dos atendidos pela rede de proteção social que ao se desligarem dos serviços deixaram de dormir na rua nos abrigos e casas de convivência e nos programas de capacitação voltados para autonomia

número de crianças e adolescentes em situação de rua encaminhadas aos serviços da rede, atendidas pelos serviços de SAS

abrigo e convivência e pelos programas de inclusão social

motivos de desligamento dos atendidos em albergues e abrigos registrados por SIS Rua/SAS; número de participantes e dos núcleos de coleta seletiva da área central; grau participação e satisfação com as atividades dos centros a serem implantados

\section{Recuperação do Ambiente Urbano}

Opinião pública positiva com relação ao ambiente urbano, a partir de julho de 2004

avaliação dos usuários da área central quanto às mudanças do ambiente urbano

Variação no uso dos espaços públicos e culturais igual ou maior que no restante da cidade.

\section{Melhoria da Circulação e do Transporte}

Evolução do nível de satisfação do usuário, a partir de julho de 2007

Evolução do nível de serviços de D para C para pedestres, em pelo menos 50\% dos

pontos críticos da área de intervenção, a partir de julho de 2004

Fortalecimento Institucional do Município

Opinião pública positiva com relação ao centro em julho de 2004, julho de 2005, julho de

2006, julho de 2007 e julho 2008

Fonte: Regulamento Operacional (PMSP/EMURB, 2004 d) e PMSP/EMURB; FIPE 2003.

* O indicador de variação dos salários gerados na área central foi excluído na versão aprovada pelo banco em 2004, junto com o Regulamento Operacional do programa.

avaliação dos usuários do sistema de transporte na área central quanto à qualidade dos serviços

qualidade nas condições de utilização dos pontos
SAS

SAS

Pesquisa de Campo

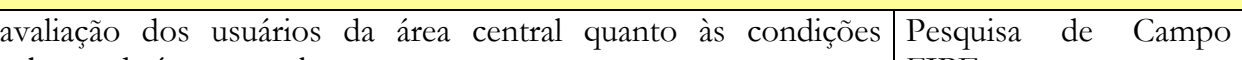

urbanas da área central

FIPE

ANTP

SPTRANS 